\title{
A Computationally Based Study of Polycyclic Nitramines and Their Precursors: Comparisons between Known and Notional Compounds
}

by Michael J McQuaid and Chiung-Chu Chen 


\section{NOTICES}

\section{Disclaimers}

The findings in this report are not to be construed as an official Department of the Army position unless so designated by other authorized documents.

Citation of manufacturer's or trade names does not constitute an official endorsement or approval of the use thereof.

Destroy this report when it is no longer needed. Do not return it to the originator. 


\section{Army Research Laboratory}

Aberdeen Proving Ground, MD 21005-50XX

\section{A Computationally Based Study of Polycyclic Nitramines and Their Precursors: Comparisons between Known and Notional Compounds}

Michael J McQuaid and Chiung-Chu Chen Weapons and Materials Research Directorate, ARL 


\section{REPORT DOCUMENTATION PAGE}

\section{Form Approved} OMB No. 0704-0188

Public reporting burden for this collection of information is estimated to average 1 hour per response, including the time for reviewing instructions, searching existing data sources, gathering and maintaining the data needed, and completing and reviewing the collection information. Send comments regarding this burden estimate or any other aspect of this collection of information, including suggestions for reducing the burden, to Department of Defense, Washington Headquarters Services, Directorate for Information Operations and Reports (0704-0188), 1215 Jefferson Davis Highway, Suite 1204, Arlington, VA 22202-4302. Respondents should be aware that notwithstanding any other provision of law, no person shall be subject to any penalty for failing to comply with a collection of information if it does not display a currently valid OMB control number.

PLEASE DO NOT RETURN YOUR FORM TO THE ABOVE ADDRESS.

\begin{tabular}{|c|c|c|}
\hline $\begin{array}{l}\text { 1. REPORT DATE (DD-MM-YYYY) } \\
\text { February } 2015\end{array}$ & $\begin{array}{l}\text { 2. REPORT TYPE } \\
\text { Final }\end{array}$ & $\begin{array}{l}\text { 3. DATES COVERED (From - To) } \\
\text { March 2013-July } 2014\end{array}$ \\
\hline \multirow{4}{*}{\multicolumn{2}{|c|}{$\begin{array}{l}\text { 4. TITLE AND SUBTITLE } \\
\text { A Computationally Based Study of Polycyclic Nitramines and Their Precursors: } \\
\text { Comparisons between Known and Notional Compounds }\end{array}$}} & 5a. CONTRACT NUMBER \\
\hline & & \\
\hline & & 5b. GRANT NUMBER \\
\hline & & 5c. PROGRAM ELEMENT NUMBER \\
\hline \multirow{3}{*}{\multicolumn{2}{|c|}{$\begin{array}{l}\text { 6. AUTHOR(S) } \\
\text { Michael J McQuaid and Chiung-Chu Chen }\end{array}$}} & 5d. PROJECT NUMBER \\
\hline & & 5e. TASK NUMBER \\
\hline & & 5f. WORK UNIT NUMBER \\
\hline \multicolumn{2}{|c|}{$\begin{array}{l}\text { 7. PERFORMING ORGANIZATION NAME(S) AND ADDRESS(ES) } \\
\text { US Army Research Laboratory } \\
\text { ATTN: RDRL-WML-D } \\
\text { Aberdeen Proving Ground, MD 21005-5066 }\end{array}$} & $\begin{array}{l}\text { 8. PERFORMING ORGANIZATION } \\
\text { REPORT NUMBER } \\
\text { ARL-TR-7186 }\end{array}$ \\
\hline \multirow{2}{*}{\multicolumn{2}{|c|}{ 9. SPONSORING/MONITORING AGENCY NAME(S) AND ADDRESS(ES) }} & 10. SPONSOR/MONITOR'S ACRONYM(S) \\
\hline & & $\begin{array}{l}\text { 11. SPONSOR/MONITOR'S REPORT } \\
\text { NUMBER(S) }\end{array}$ \\
\hline
\end{tabular}

\section{DISTRIBUTIONIAVAILABILITY STATEMENT}

Approved for public release; distribution is unlimited.

\section{SUPPLEMENTARY NOTES}

\section{ABSTRACT}

A computationally based study was conducted to assess the potential viability of schemes proposed for employing cucurbiturils as precursors for the synthesis of polycyclic nitramines (PCNAs). One scheme involved reducing cucurbiturils to cucurbitaminals, then nitrolyzing them. The other involved hydrolyzing the cucurbiturils, then nitrating the secondary amine groups of the product. To assess the schemes' viabilities, an attempt was made to establish correlations between properties of equilibrium molecular structures and stability for known compounds, then employ the correlations to predict the stabilities of intermediates and targets. However, strong correlations were not found. Moreover, even if more evidence supporting hypothesized correlations had been found, results for the intermediates and targets of interest suggest that the yields of these schemes are likely to be low (at best) and that the targets will be unstable. The attempt to answer questions regarding the feasibility of producing PCNAs from cucurbiturils prompted the design and modeling of other notional PCNAs. Two appear to warrant further investigation. One is 2,6,7-trinitro-2,6,7-triaza[2.2.2]octane. It has a tris(nitramino) group. The other is a CL-20 analog with $4>\mathrm{C}(\mathrm{H}) \mathrm{C}(\mathrm{H})<$ groups and 4 nitramine groups.

\section{SUBJECT TERMS}

nitramines, propellants, explosives, computational chemistry, propulsion, synthesis

\begin{tabular}{|l|l|l|c|c|l|}
\hline \multicolumn{2}{|l|}{ 16. SECURITY CLASSIFICATION OF: } & $\begin{array}{c}\text { 17. LIMITATION } \\
\text { OF ABSTRACT }\end{array}$ & $\begin{array}{l}\text { 18. NUMBER } \\
\text { OF PAGES }\end{array}$ & $\begin{array}{l}\text { 19a. NAME OF RESPONSIBLE PERSON } \\
\text { Michael J McQuaid }\end{array}$ \\
\cline { 1 - 2 } $\begin{array}{l}\text { a. REPORT } \\
\text { Unclassified }\end{array}$ & $\begin{array}{l}\text { b. ABSTRACT } \\
\text { Unclassified }\end{array}$ & $\begin{array}{l}\text { c. THIS PAGE } \\
\text { Unclassified }\end{array}$ & UU & 132 & $\begin{array}{l}\text { 19b. TELEPHONE NUMBER (Include area code) } \\
410-278-6185\end{array}$ \\
\hline
\end{tabular}




\section{Contents}

List of Figures $\quad$ v

List of Tables

Acknowledgments $\quad$ vii

1. Introduction $\quad 1$

2. Literature Search for Molecular and Compound Properties 9

$\begin{array}{ll}\text { 3. Computational Methods } & 9\end{array}$

$\begin{array}{lr}\text { 4. Results } & 10\end{array}$

4.1 Findings Related to Scheme II ........................................................................10

4.1.1 Noncage Uril Equilibrium Structures: Geometric Parameters and Relative

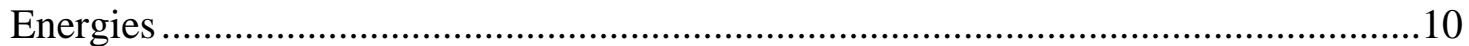

4.1.2 Cucurbituril Structures: Geometric Parameters and Relative Energies ............13

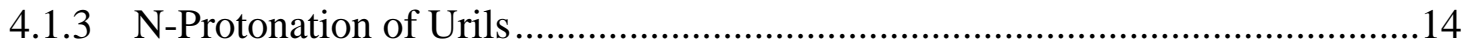

4.2 Findings Related to Scheme I........................................................................18

4.2.1 Noncage Aminal Equilibrium Structures: Geometric Parameters ....................18

4.2.2 Cucurbitaminal Structures: Geometric Parameters and Relative Energies .......23

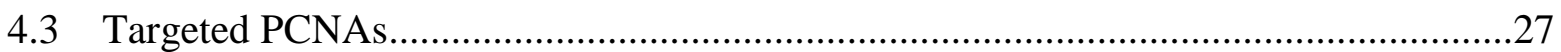



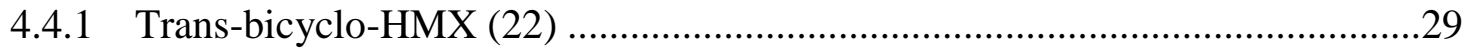

4.4.2 2,6,7-Trinitro-2,6,7-triaza[2.2.2] octane (23) ...............................................30

4.4.3 Notional PCNAs With Just $>\mathrm{C}(\mathrm{H}) \mathrm{C}(\mathrm{H})<$ and $>\mathrm{N}-\mathrm{NO}_{2}$ Groups ......................32

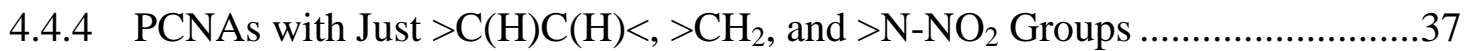

5. Summary and Conclusions $\quad 38$

$\begin{array}{lr}\text { 6. Notes } & 40\end{array}$

7. $\quad$ References $\quad 41$ 
Appendix A. B3LYP/6-31G(p,d)-Based Geometries and 0.001 Electron/Bohr ${ }^{3}$ Isosurface Parameters

Appendix B. Gas-Phase Enthalpies of Formation at $298 \mathrm{~K}\left[\Delta H_{f}(298)\right]$ and $\mathrm{N}-\mathrm{NO}_{2}$ Bond Dissociation Energies

Distribution List 


\section{List of Figures}

Fig. 1 Molecular structures of RDX, HMX, and CL-20 ....................................................2

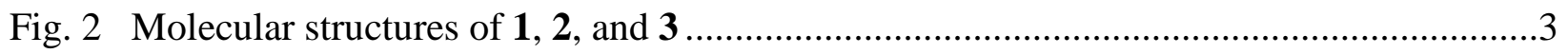

Fig. 3 Synthesis route for 4 (Nielsen et al. 1998) ...............................................................4

Fig. 4 Molecular structures of the precursor (HMTA) for the industrial-scale production of RDX and HMX and a proposed precursor (nonamethylenehexamine, NMHA) for the formation of 10- and 12-membered monocyclic nitramines (McQuaid and Drake 2009) ........4

Fig. 5 Molecular structures of CB[5], CB[6], and CB[7] ....................................................5

Fig. 6 Scheme I: Proposed approach for creating PCNAs from cucurbiturils.............................6

Fig. 7 Scheme II: Proposed approach for creating PCNAs from cucurbiturils ..........................6

Fig. 8 Ring-opening mechanism of 15 that was postulated by Koppes et al. (1987) ..................7

Fig. 9 Scheme III: Approach for creating large monocyclic nitramines from cucurbiturils..........8

Fig. 10 Molecular structures of a CL-20 precursor and one of its isomers ..............................9

Fig. 11 Molecular structures of urils (H-atoms are not shown. CB[5] has been “Z-clipped.”)...11

Fig. 12 Molecular structures of targets of the hydrolysis of $\mathrm{CB}[5](\mathbf{1 0 a}-\mathbf{c})$ and $\mathrm{CB}[6]$

(11a-c)

Fig. 13 Molecular structures of aminals (H-atoms are not shown. CB[5]A is “Z-clipped”.)......18

Fig. 14 Molecular structures for targets of the nitrolysis of CB[5]A (20) and CB[6]A (21)......28

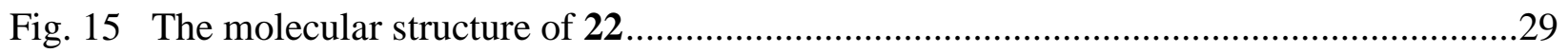

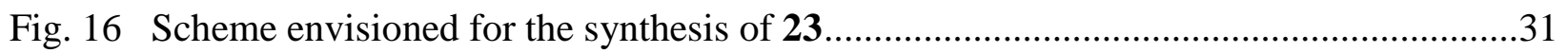

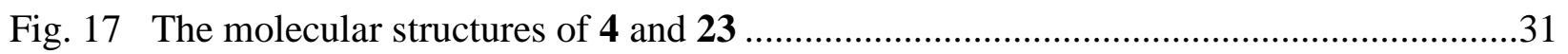

Fig. 18 Molecular structures of notional $\mathrm{PCNAs}$ with just $>\mathrm{CHCH}<$ and $>\mathrm{NNO}_{2}$ groups: 24-30.

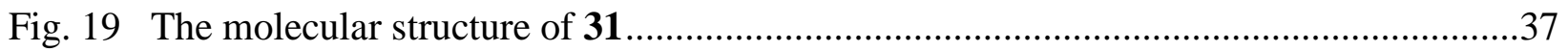

Fig. 20 Molecular structures for PCNAs with $\mathrm{C}_{6} \mathrm{H}_{6} \mathrm{~N}_{14} \mathrm{O}_{14}$ stoichiometry ...............................37

Fig. B-1 Notional conformers of HMX

Fig. B-2 Recommended vs. estimated $\Delta_{f} H_{g}(298)$ values for molecules listed in Table B-1.

(a) B3LYP/6-31+g(d,p); (b) MPWB95/6-31+g(d,p); and (c) BHandHLYP/3-21g(d). Note that the red data points were not included in the least-squares fit. 


\section{List of Tables}

Table 1 Predicted bond lengths ( $r_{e}$ in angstroms) for noncage urils ......................................12

Table 2 Predicted bond lengths ( $r_{e}$ in angstroms) and gas-phase $H(298)$ /monomer unit values for cucurbiturils

Table 3 Predicted bond lengths ( $r_{e}$ in angstroms) for N-protonated noncage urils and proton affinities (in kilocalories per mole) for their conjugate bases: B3LYP/6-31+G(d,p) results...14

Table 4 Predicted bond lengths ( $r_{e}$ in angstroms) for N-protonated cucurbiturils and proton affinities (in kilocalories per mole) for their conjugate bases..............................................16

Table 5 Predicted bond lengths ( $r_{e}$ in angstroms) for cucurbituril hydrolysis targets 10a and

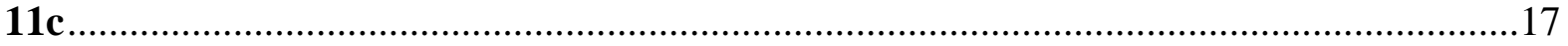

Table 6 Predicted bond lengths ( $r_{e}$ in angstroms) for noncage aminals ..................................19

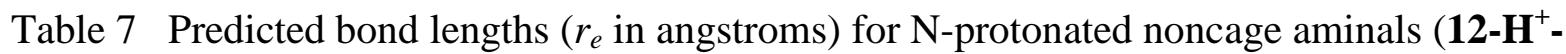
16-H ${ }^{+}$) and $\mathbf{H M T A}-\mathbf{H}^{+}$, and proton affinities (in kilocalories per mole) for their conjugate

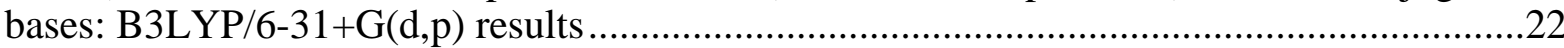

Table 8 Predicted bond lengths ( $r_{e}$ in angstroms) and gas-phase $H(298) /$ monomer unit estimates for cucurbitaminals and $\mathbf{3 1}$

Table 9 Predicted bond lengths ( $r_{e}$ in angstroms) for N-protonated noncage aminals (17- $\mathbf{H}^{+}$ and $\mathbf{1 9}-\mathbf{H}^{+}$) and proton affinities (in kilocalories per mole) for their corresponding conjugate base: B3LYP/6-31+G(d,p) results .

Table 10 Predicted bond lengths ( $r_{e}$ in angstroms) for N-protonated cucurbitaminals and $\mathbf{3 1}$ and proton affinities (in kilocalories per mole) for their conjugate bases ..............................26

Table 11 Property predictions for PCNA targets of Schemes I and II: 20 and 21....................29

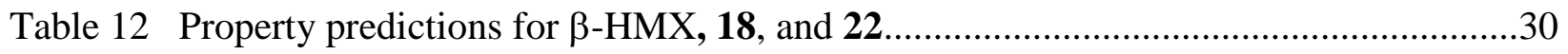

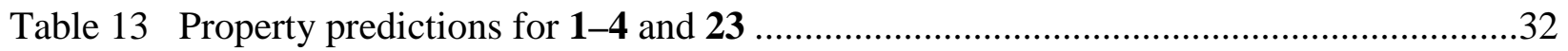

Table 14 Property predictions for $\mathrm{PCNAs}$ with just $>\mathrm{CHCH}<$ and $>\mathrm{NNO}_{2}$ groups...................34

Table A-1 Properties of the 0.001 electron/bohr ${ }^{3}$ isosurface ....................................................105

Table B-1 Gas-phase $\Delta_{f} H_{g}$ (298) estimates (in kilocalories per mole) for relatively small PCNAs and molecules employed as bases for calculating gas-phase $\Delta_{f} H_{g}$ (298)estimates for larger PCNAs

Table B-2 Gas-phase $\Delta_{f} H_{g}$ (298) estimates (in kilocalories per mole) for 1, 2, 3, 20, 21, 26, 27, 28, 29, 30, and $\varepsilon$-CL-20.

Table B-3 Estimates for PCNA N-NO 2 bond dissociation energies (in kilocalories per mole) 118 


\section{Acknowledgments}

Discussions with Dr G Drake (US Army Aviation and Missile Research, Development and Engineering Center) motivated this study. We are grateful to him for sharing his knowledge and perspective regarding energetic material synthesis and development. Dr EFC Byrd (US Army Research Laboratory [ARL]) supplied the programs that were employed to calculate properties of electron isodensity surfaces. Most of the study's calculations were performed on Department of Defense Shared Resource Center computers maintained at Wright Patterson Air Force Base, $\mathrm{OH}$, and Aberdeen Proving Ground, MD. Dr WM Sherrill (ARL) provided a technical review of the manuscript. His feedback was appreciated. 
INTENTIONALLY LEFT BLANK. 


\section{Introduction}

To improve the lethality and survivability of its weapons systems, the US Army is interested in developing energetic materials for propellants and explosives that have better performance properties than current standards but are less sensitive to ignition stimuli produced by various threats. Much of the research effort devoted to achieving these goals has focused on finding replacements for the nitramines 1,3,5-trinitro-1,3,5-triazacyclohexane (RDX) and 1,3,5,7tetranitro-1,3,5,7-tetraazacyclooctane (HMX). One candidate that has received considerable attention is another nitramine: 2,4,6,8,10,12-hexanitro-2,4,6,8,10,12-hexaazaisowurzitane (CL-20). Unlike the monocyclic molecular structures of RDX and HMX, CL-20's molecular structure includes a polycyclic cage (Fig. 1). Representing a compact arrangement of atoms with a relatively high amount of strain energy, CL-20 has a higher density and a more positive (condensed-phase) enthalpy of formation $\left(\Delta_{f} H_{c}\right)$ than either RDX or HMX. In addition, CL-20 is closer to stoichiometric for $\mathrm{CO}_{2}$ and $\mathrm{H}_{2} \mathrm{O}$ than the 2 standards. ${ }^{1}$ These attributes combine to produce better propulsive and explosive performance potential. However, CL-20 is more sensitive to shock and impact initiation, and it is far more expensive to make. Therefore, its use in military applications has been extremely limited. 

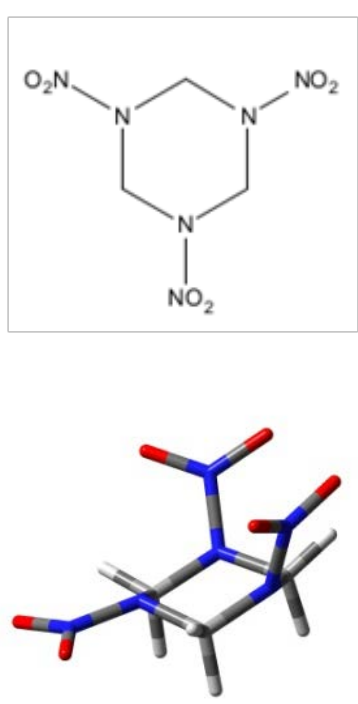

$\alpha$

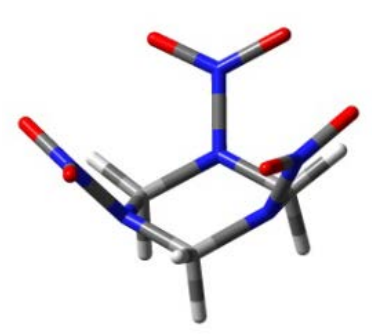

$\beta$
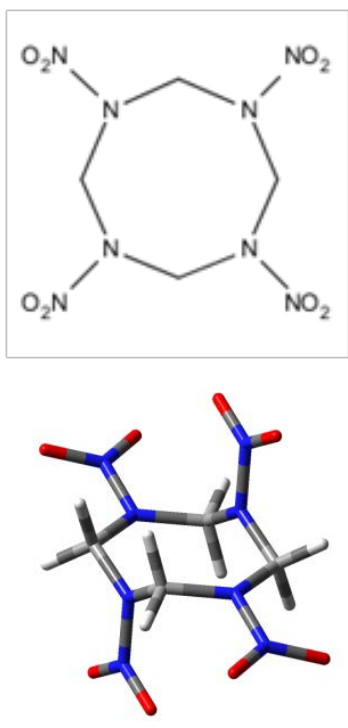

$\beta$

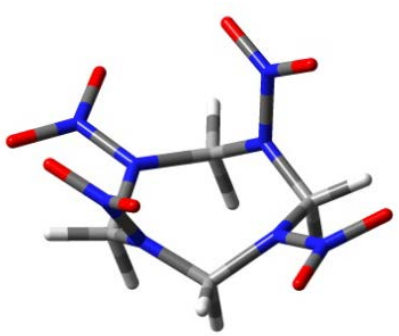

$\delta$
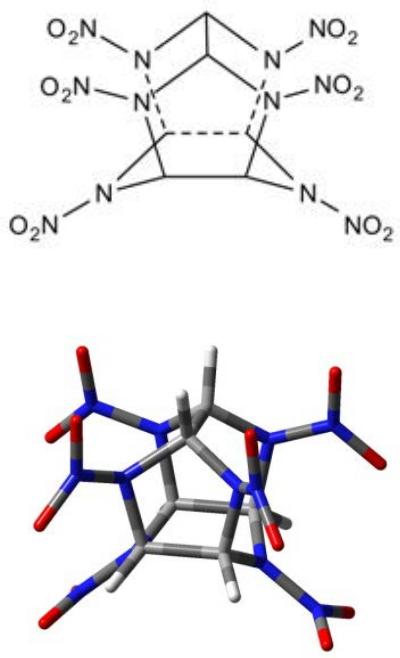

$\varepsilon$

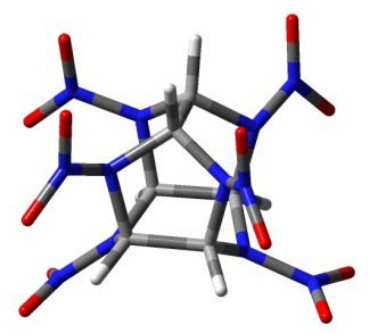

$\gamma$

HMX

Fig. 1 Molecular structures of RDX, HMX, and CL-20

The syntheses of other polycyclic nitramines (PCNAs) have been reported, and a relatively recent review of procedures that have been employed to make them has been published by Sysolyatin et al. (2007). Most involve nitrating a precursor produced from the condensation of formaldehyde or glyoxal and an amine. As such, they recall the Bachmann process (Bachmann and Sheehan 1949, von Herz 1921). Employed for the industrial-scale production of RDX and HMX, the Bachmann process involves 2 steps. The first is the production of hexamethylenetetramine (HMTA) via the condensation of formaldehyde and ammonia. This step is facile and inexpensive. The second step involves nitrolyzing HMTA — that is, breaking C-N bonds and adding $-\mathrm{NO}_{2}$ groups to the resulting secondary $\mathrm{N}$-atoms. To produce PCNAs, however, more than 2 steps are typically required, and the performance gains (if any) have been insufficient to warrant the cost incurred because of them. 
In addition to the PCNAs that have been synthesized, there are many notional PCNAs that have been designed and characterized via computationally based methods. 2,4,6,8,9,10-hexanitro2,4,6,8,9,10-hexaazatricyclo[3.3.1.1 $1^{3,7}$ decane (1) (Dzyabchenko et al. 1996), 2,4,6,8,10,12,13,14,15-nonanitro-2,4,6,8,10,12,13,14,15-nonaazaheptacyclo[5.5.1.1 $\left.1^{3,11} .1^{5,9}\right]$ pentadecane (2) (Zhang et al. 2012), and dodecanitro-dodececaazapentacyclo[9.5.1 $\left.1^{3,9} \cdot 1^{5,15} \cdot 1^{7,13}\right]$ icosane (3) (Ju and Wang 2009) are good examples (Fig. 2). They are predicted to have exceptional performance potential, and predictions for their $\mathrm{N}-\mathrm{NO}_{2}$ bond dissociation energies (BDEs) were taken to suggest that they will be thermally stable. Moreover, having $\Phi=0.83$, they are true oxidizers, which, from the standpoint of formulating propellants and explosives with fuel-rich binders, makes them even more attractive. However, there is no evidence that they have ever been isolated. (Data presented by Agrawal [1998] implies that 1 has been isolated, but we could find no other reference that supports this inference.)
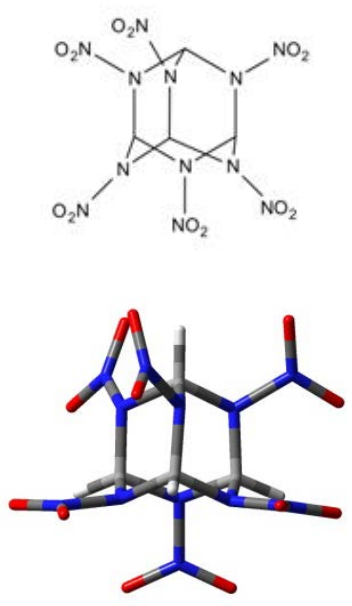

1
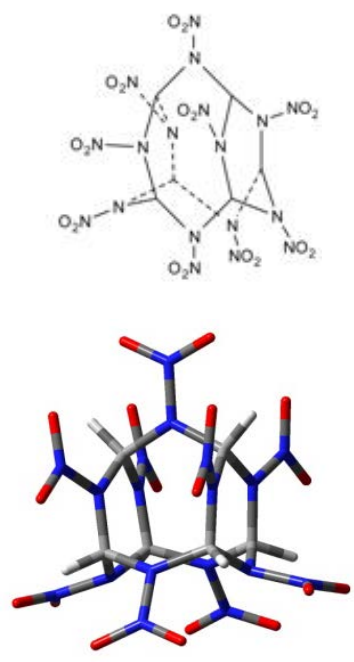

2
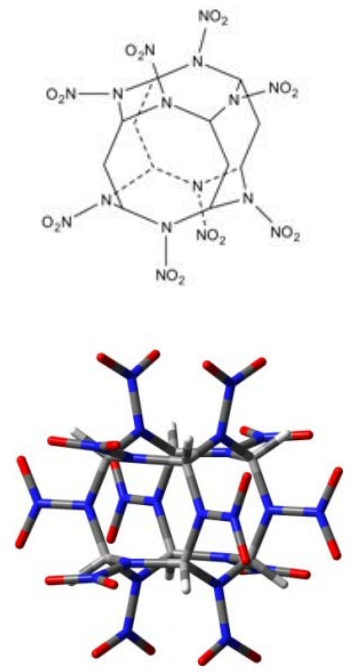

3

Fig. 2 Molecular structures of 1, 2, and 3

While we had no reason to doubt that the predictions for the dissociation energies of 1-3's N$\mathrm{NO}_{2}$ bonds were reasonably accurate, we doubted they represented a reliable basis for predicting the stabilities of 1-3. Intramolecular and intermolecular rearrangements (such as $\mathrm{H}$-atom abstractions) could conceivably offer lower energy pathways to decomposition and therefore would have to be investigated if one wanted a more reasonable degree of assurance of 1-3's stabilities prior to undertaking their synthesis. In addition, even if positive indications were produced by such a study, they would not guarantee stability, and other significant issues would still have to be addressed. For one, it is not possible, even "in principle," " to design a 2-step process for the synthesis of $\mathbf{1}, \mathbf{2}$, or $\mathbf{3}$ that would involve a formaldehyde-amine or glyoxal-amine condensation followed by nitrolysis. Amine-formaldehyde condensations produce $>\mathrm{NCH}_{2} \mathrm{~N}<$ groups, amine-glyoxal condensations produce $>\mathrm{NCH}(\mathrm{C}) \mathrm{N}<$ groups, and $\mathbf{1}-\mathbf{3}$ comprise just $>\mathrm{CH}$ and $>\mathrm{N}-\mathrm{NO}_{2}$ groups that are grouped exclusively in tris(nitramino)methane fragments 
$[>\mathrm{NCH}(\mathrm{N}<) \mathrm{N}<$ ]. Indeed, the only compound with a tris(nitramino)methane fragment that appears to have been isolated is 2,4,10-trinitro-2,4,10-triazaadamantane (4). It was synthesized by Nielsen et al. (1998) as outlined in Fig. 3, but it was reported that only "a small amount of partially crystalline” material was produced. Thus, established procedures offer little guidance with respect to how one might synthesize $\mathbf{1}$, 2, or $\mathbf{3}$ affordably or otherwise.

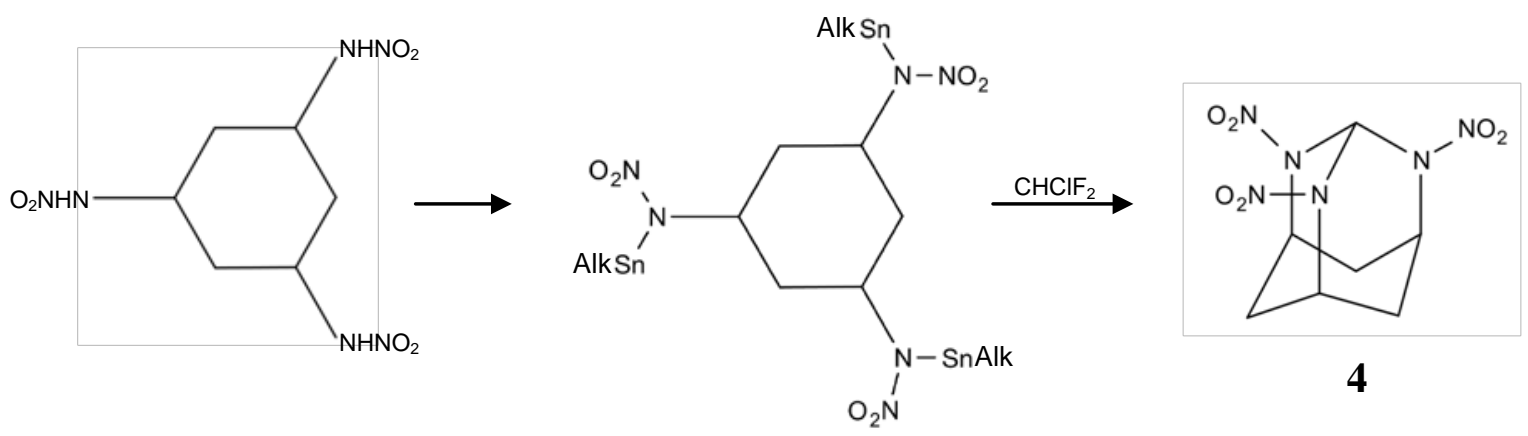

Fig. 3 Synthesis route for 4 (Nielsen et al. 1998)

Given performance gains that were expected from 10- and 12-membered monocyclic nitramines and recognizing the importance of having an approach to their synthesis that required only a few steps, McQuaid and Drake (2009) proposed notional precursors and conducted a computationally based study to predict the precursors' stability/isolability. The molecular designs of the precursors were based (in part) on consideration of the Bachmann process. That is, larger "aminal” analogs of HMTA were designed that (in principle) had the potential to be nitrolyzed to produce 10- and 12-membered rings composed of alternating $>\mathrm{NNO}_{2}$ and $>\mathrm{CH}_{2}$ groups.

(Aminals are molecules that include a $>\mathrm{NCH}_{2} \mathrm{~N}<$ group.) An example is compared to HMTA in Fig. 4.

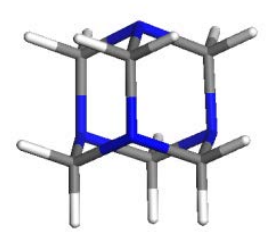

HMTA

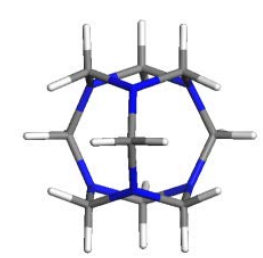

NMHA

Fig. 4 Molecular structures of the precursor (HMTA) for the industrial-scale production of RDX and HMX and a proposed precursor (nonamethylenehexamine, NMHA) for the formation of 10- and 12-membered monocyclic nitramines (McQuaid and Drake 2009) 
Considering means for extending the approach proposed for synthesizing large monocyclic nitramines to an approach for synthesizing PCNAs having just $\mathrm{CH}$ and/or $>\mathrm{CH}_{2}$ groups (besides the $>\mathrm{NNO}_{2}$ groups), we identified the possibility that cucurbiturils might be reduced to aminals that could be nitrolyzed to produce desirable targets. Macromolecular cages that derive their name from their resemblance to pumpkins (Freeman et al. 1981), cucurbiturils are created by reacting formaldehyde with glycoluril (7). Varieties having from 5 to 10 (glycoluril) monomer units are commercially available. The most common one comprises 6 monomer units (CB[6]) (Fig. 5). Since their discovery, cucurbiturils have been found to have many intriguing properties, and there has been a tremendous amount of research devoted to exploiting them for the development of “smart” materials. (See, for example, the review by Masson et al. [2012].)
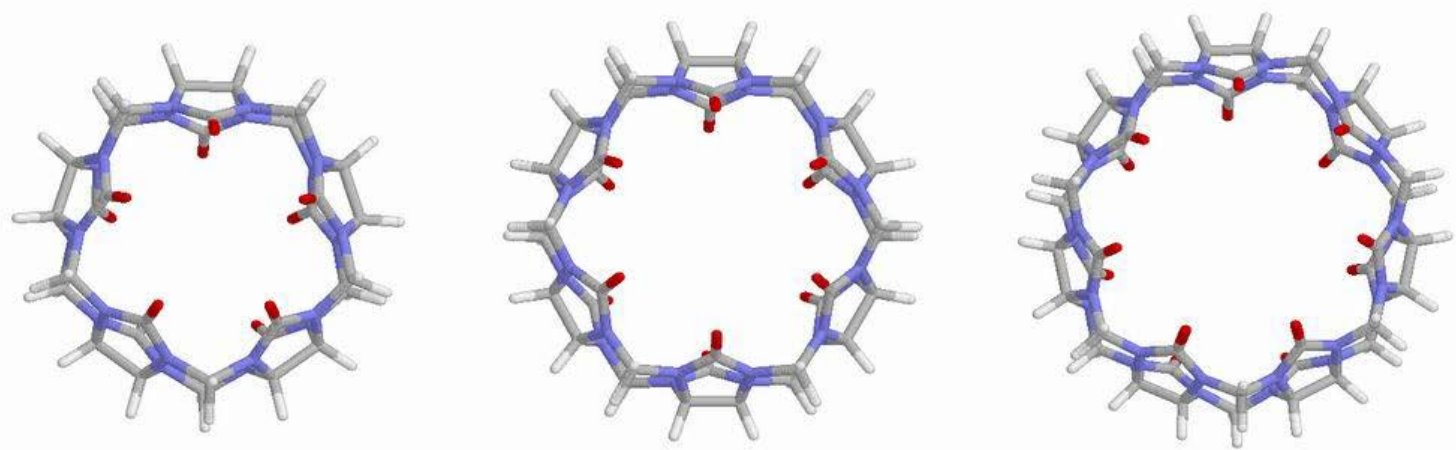

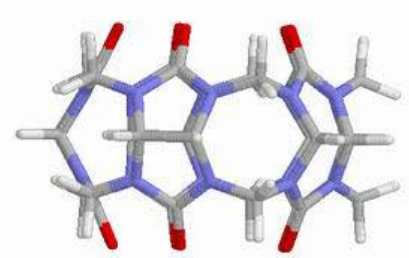

$\mathrm{CB}[5]$

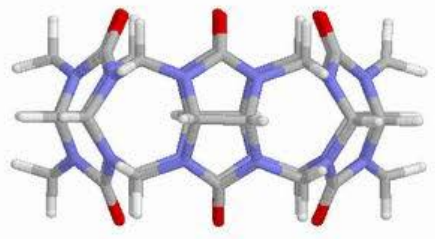

$\mathrm{CB}[6]$

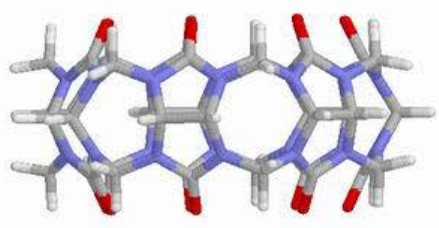

$\mathrm{CB}[7]$

Fig. 5 Molecular structures of $\mathrm{CB}[5], \mathrm{CB}[6]$, and $\mathrm{CB}[7]$

If all the urea groups in a cucurbituril ( $\mathrm{CB}[\mathrm{n}]$ ) were fully reduced (from $>\mathrm{C}=\mathrm{O}$ to $>\mathrm{CH}_{2}$ ), the resulting "cucurbitaminal” ( $\mathrm{CB}[\mathrm{n}] \mathrm{A})$ would have 2 different $-\mathrm{CH}_{2}$ - types: (1) those originating with the uril group $\mathrm{C}$-atoms $\left(\mathrm{C}_{\mathrm{u}}\right)$ in glycoluril and (2) the bridging groups traceable to formaldehyde $\left(C_{b}\right)$. If the $\mathrm{C}_{\mathrm{u}}-\mathrm{N}$ bonds could then be selectively scissioned and $-\mathrm{NO}_{2}$ groups added to the participating $\mathrm{N}$-atoms (as occurs in the nitrolysis of HTMA), the product would be a PCNA. Shown in Fig. 6, this approach is hereafter referred to as Scheme I. Having stoichiometries with the general form $\mathrm{C}_{2 \mathrm{x}} \mathrm{H}_{3 \mathrm{x}} \mathrm{N}_{4 \mathrm{x}} \mathrm{O}_{4 \mathrm{x}}$, the targets of Scheme I would have $\Phi=$ 1.375, which is closer to 1.0 than are the $\Phi$ s of RDX and HMX. Besides the possibility that the targets would have good performance properties, it was envisioned that, like the cucurbiturils, the PCNAs that were produced could be exploited to design smart materials. 


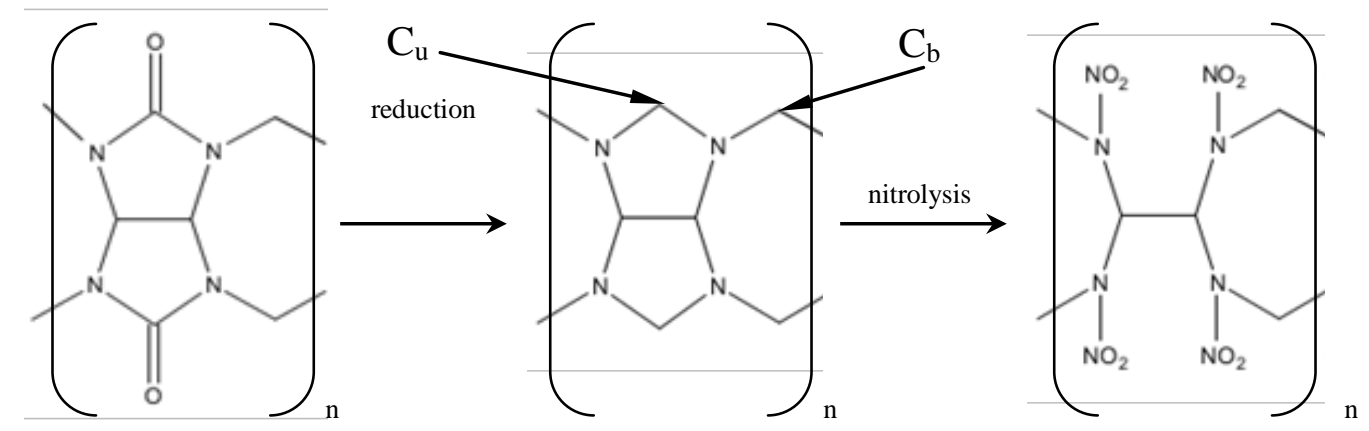

Fig. 6 Scheme I: Proposed approach for creating PCNAs from cucurbiturils

Another approach to producing PCNAs from cucurbiturils is suggested by a procedure employed to produce ethylenedinitramine (Pagoria et al. 1996). The procedure involved treating 2imidizolidinone with di-tert-butyl dicarbonate [(BOC $\left.)_{2} \mathrm{O}\right]$ to produce 1,3-bis-(N-tertbutoxycarbonyl)-2-imidizolidinone [1,3-bis-(BOC)-2-imidizolidinone] (Flynn et al. 1983). 1,3bis-(BOC)-2-imidizolidinone was treated with aqueous lithium hydroxide to produce bis(BOC)ethylenediamine, and this product was treated with $\mathrm{HNO}_{3}$ /acetic anhydride to produce bis(nitro)-bis(BOC)ethylenediamine. A corollary of this approach for the production of PCNAs from cucurbiturils, and hereafter referred to as Scheme II, is shown in Fig. 7.

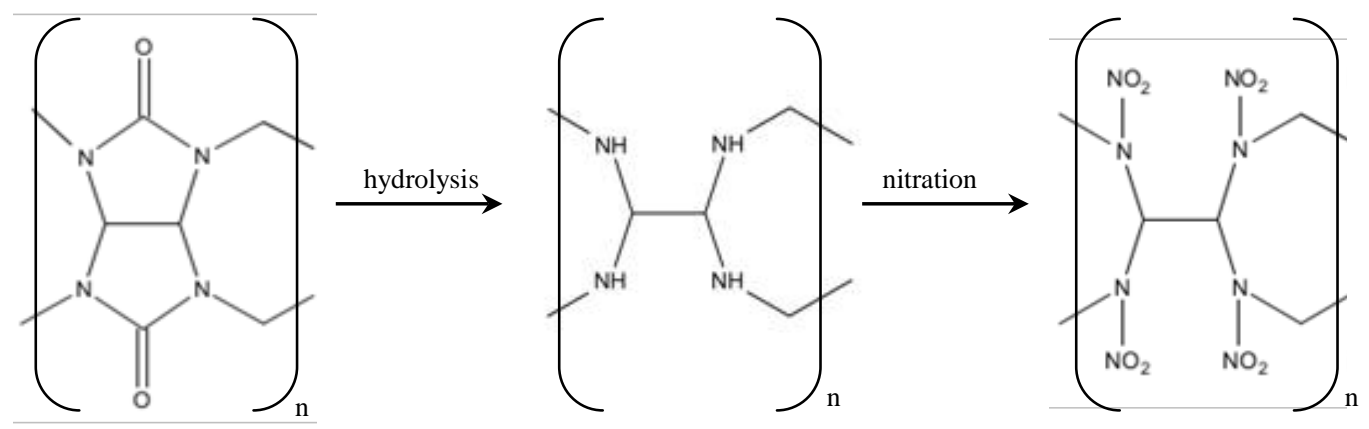

Fig. 7 Scheme II: Proposed approach for creating PCNAs from cucurbiturils

Sysolyatin et al. (2007) mention that attempts to introduce nitro groups into cucurbiturils and hexacyclic systems (formed from the reaction of glycoluril, formaldehyde, and diamines) were not successful. However, they do not mention what was attempted or who attempted it. Given the reduction of 2,4,6,8-tetramethyl-2,4,6,8-tetrazabicyclo[3.3.0]octane-3,7-dione (8) to 2,4,6,8tetramethyl-2,4,6,8-tetrazabicyclo[3.3.0]octane (14) that was reported by Nelsen and Hintz (1972), and later by Koppes et al. (1987), we assumed it was possible to fully reduce a CB[n] to its corresponding CB[n]A. However, Koppes et al. (1987) observed that 2,4,6,8-tetraisopropyl2,4,6,8-tetrazabicyclo[3.3.0]-octane (15) had an extremely short storage life, raising a concern about the stability/isolability of cucurbitaminals. An attempt to address this concern was therefore undertaken. Employing a B3LYP-based model (Becke 1993, Lee et al. 1988, Stephens et al. 1994, Vosko et al. 1980) to predict geometric parameters for CB[n]A equilibrium 
molecular structures, we examined whether any unusually long bond lengths were produced. (While the absence of unusually long bond lengths is not particularly reliable with respect to predicting stability, unusually long bond lengths are considered a reliable predictor of instability.) In addition, geometric parameters for equilibrium structures of known aminals were modeled and analyzed to determine if "subtle" correlations between bond lengths and stability could be observed. $\mathrm{N}-\mathrm{NO}_{2}$ BDEs for the notional structures were also estimated, with the same limitation of their ability to predict stability recognized. That is, low $\mathrm{N}-\mathrm{NO}_{2} \mathrm{BDEs}$ are reliable with respect to predicting instability, but the lack of low $\mathrm{N}-\mathrm{NO}_{2}$ BDEs is no guarantee that a compound will be isolable.

Besides requiring the intermediate aminals to be isolable, Schemes I and II require that $\mathrm{C}_{\mathrm{u}}-\mathrm{N}$ bonds scission while the other $\mathrm{C}-\mathrm{N}$ bonds remain intact. Therefore, a simple means for predicting whether that might happen was sought. Inspired by the ring-opening mechanism that Koppes et al. (1987) postulated for the acid nitrolysis of $\mathbf{1 5}$ (Fig. 8), we employed the B3LYP model to predict the change in C-N bond lengths produced upon N-protonation of the urils and aminals of interest. Our hypothesis was that the longest $\mathrm{C}-\mathrm{N}\left(\mathrm{H}^{+}\right)$bond would correspond to the bond that would be most likely to break. Relatively simple systems that test this hypothesis were identified and modeled. The results are discussed herein.

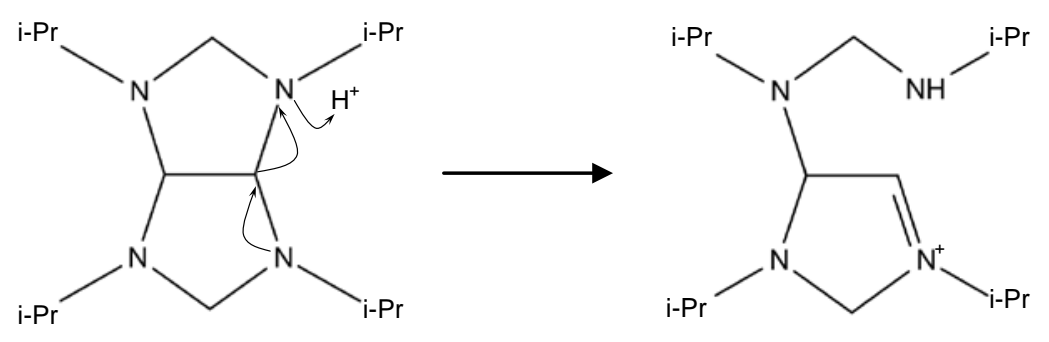

Fig. 8 Ring-opening mechanism of $\mathbf{1 5}$ that was postulated by Koppes et al. (1987)

The postulated ring-opening mechanism also led us to appreciate that cucurbitaminal C-N bonds associated with the $\mathrm{C}$-C group $\mathrm{C}$-atoms $\left(\mathrm{C}_{\mathrm{c}}\right)$ might preferentially break. If so, cucurbitaminals might be induced to unzip along the $\mathrm{C}_{\mathrm{c}}-\mathrm{C}_{\mathrm{c}}$ spine, producing monoheterocycles with twice as many nitramine groups as the precursor had monomer units (Fig. 9). 


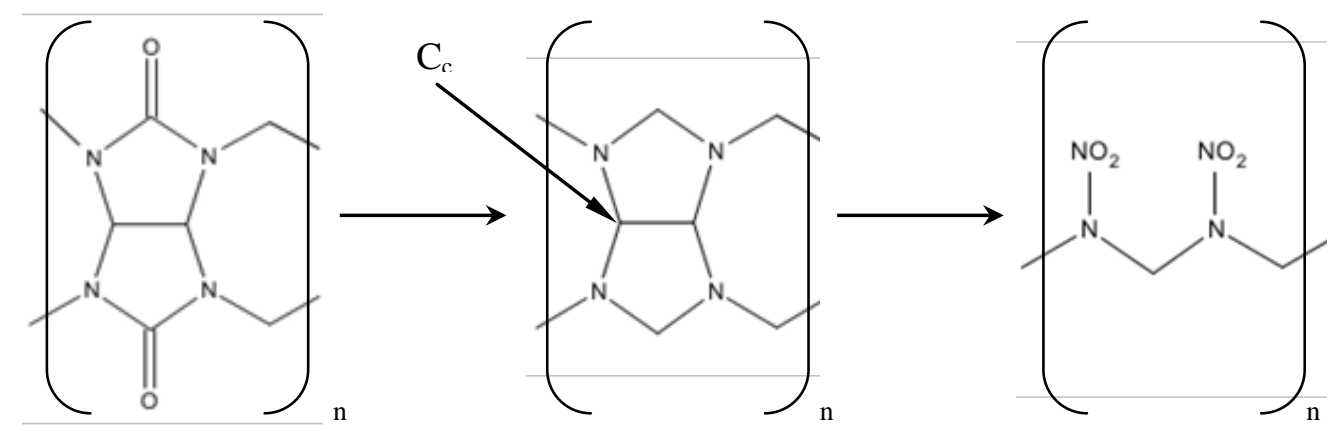

Fig. 9 Scheme III: Approach for creating large monocyclic nitramines from cucurbiturils

The large number of atoms in the cucurbiturils and cucurbitaminals makes it possible for a large number of equilibrium configurations (i.e., local energy minima) to exist. Therefore, structures for known molecules that correspond to the 5- and 8-membered cyclic substructures found within the cucurbiturils and cucurbitaminals were modeled to guide the effort to build starting structures that would lead to relatively low energy conformers.

The work that was performed to assess the feasibility of Schemes I and II led to the design and modeling of some other PCNAs. Our specific interest, and the only one discussed in this report, was PCNAs having just $\mathrm{CH}$ and/or $\mathrm{CH}_{2}$ groups and no adjacent $>\mathrm{NNO}_{2}$ groups. One was a conformer of 2,4,6,8-tetranitro-2,4,6,8-tetrazabicyclo-[3.3.0]octane ("bicyclo-HMX", 18) that has a configuration that more closely resembles $\beta$-HMX than its one known polymorph. Others were molecules that, like CL-20, could be considered to be composed of just $>\mathrm{N}-\mathrm{NO}_{2}$ and $>\mathrm{CHCH}<$ groups. Interest in this family arose from the observation that one precursor for CL-20 is the sulfamate shown in Fig. 10. It can be considered to be composed of just 2 groups, $>\mathrm{NSO}_{3} \mathrm{M}(\mathrm{M}=\mathrm{Na}$ or $\mathrm{K}$ ) and $>\mathrm{CH}-\mathrm{CH}<$. As such, it could (in principle) be formed directly from the reaction of glyoxal and $\mathrm{H}_{2} \mathrm{NSO}_{3} \mathrm{M}(\mathrm{M}=\mathrm{Na}$ or $\mathrm{K})$. (That result has not been reported.) Moreover, one of its isomers, which is also shown in Fig. 10, could by this same reasoning be formed as well. However, we were unable to find any evidence that the isomer or its corresponding nitramine (26) has ever been synthesized. (Nielsen et al. [1998] discuss an approach to the synthesis $\mathbf{2 6}$ that was not successful.) Thinking that the difference in the ability to produce CL-20 and $\mathbf{2 6}$ might be related to the difference in their energies, we estimated it. Designs with one more and one less set of $\left(>\mathrm{CHCH}<+2>\mathrm{NNO}_{2}\right.$ ) groups were also modeled to assess the potential for their synthesis. A notional precursor with the high degree of symmetry found in HMTA is proposed for one of them. 

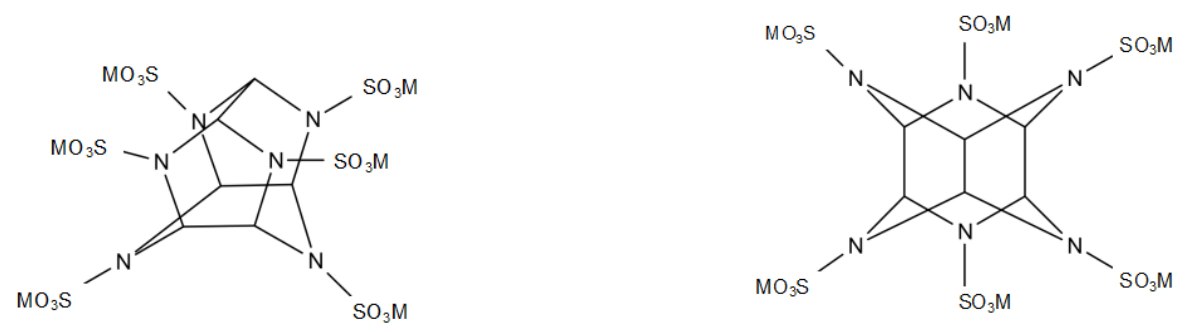

Fig. 10 Molecular structures of a CL-20 precursor and one of its isomers

Finally, the study motivated consideration of alternatives to 2,4,10-tris(trimethylstannyl)-2,4,10triazaadamantane for the production of PCNAs with a tris(nitramino) fragment. One is presented in Section 4.4.2.

\section{Literature Search for Molecular and Compound Properties}

The search of open literature sources for species properties was primarily conducted via the Cambridge Structural Database (Conquest Ver. 1.15, Cambridge Crystallographic Data Center) and 2 Websites: SciFinder (https://scifinder.cas.org, last accessed December 2013) and Web of Knowledge (http://apps.webofknowledge.com, last accessed December 2013).

\section{Computational Methods}

Predictions for molecular properties were obtained from quantum chemistry models implemented via the Gaussian09 suite of codes (Frisch et al. 2009). Geometric parameters for equilibrium configurations of isolated molecules were produced with a B3LYP/6-31+G(d,p) model. (The basis set was developed by Petersson et al. [1988], Petersson and Al-Laham [1991], and Clark et al. [1983].) Geometries based on MPWB95/6-31+G(d,p) (Adamo and Barone 1998, Becke 1996) and BHandHLYP/3-21G(d) (Becke 1988, Lee et al. 1988, Miehlich 1989) models were also produced for relatively large structures. Starting structures for the geometry optimizations were constructed with Gaussview 5.0 (Gaussian, Inc.). Structures for cucurbituril hydrates were imported from the Cambridge Structural Database, then modified to obtain starting structures for the cucurbiturils. Optimized cucurbituril structures were modified to obtain starting structures for target hydrolysis products, cucurbitaminals, and PCNAs. The convergence criteria for the geometry optimizations were the Gaussian09 defaults: Maximum Force = 0.000450, Root Mean Square (RMS) Force $=0.000300$, Maximum Displacement $=0.001800$, RMS Displacement $=0.001200$. For future reference and study, B3LYP/6-31+G(d,p)-based Cartesian coordinate representations for all the structures discussed in this report are given in Appendix A. 
Normal mode analyses were performed to confirm that the structures meeting the convergence criteria were indeed equilibrium configurations. They were also the basis for zero-point vibrational energy (ZPVE) estimates. However, for molecules with more than 56 heavy atoms, the B3LYP/6-31+G(d,p) frequency calculations proved to be impractical. Therefore, the B3LYP/6-31+G(d,p)-based optimized geometries were employed as starting points for B3LYP/6-31G(d) optimization and frequency calculations, and the ZPVE estimates were obtained from them. (The ZPVE estimates were not scaled.) The ideal-gas law was assumed in calculating the PV term needed for the computation of enthalpies at $298 \mathrm{~K}$ [H(298)].

Gas-phase enthalpies of formation at $298 \mathrm{~K}\left[\Delta_{f} H_{g}(298)\right]$ and $\mathrm{N}-\mathrm{NO}_{2}$ BDEs were estimated by calculating enthalpies of reaction for (hypothetical) isodesmic reactions. To the extent that they were computationally tractable, composite methods were employed for the effort. Included were CBS-QB3 (Montgomery et al. 2000), G3MP2B3 (Baboul et al. 1999), G4 (Curtiss et al. 2007), and G3MP2 (Curtiss et al. 1999). The reactions and data employed to produce the estimates are provided in Appendix B. Enthalpy of sublimation $\left(\Delta H_{\mathrm{s}}\right)$ and density $(\rho)$ estimates were obtained with a model that was initially developed by Rice et al. (1999) and later refined by Byrd (2012). Appendix B lists the parameters found and employed to produce the estimates.

\section{Results}

\subsection{Findings Related to Scheme II}

\subsubsection{Noncage Uril Equilibrium Structures: Geometric Parameters and Relative Energies}

Known noncage urils were modeled to obtain guidance in building starting structures for cucurbiturils that would lead to low-energy conformers. In addition, systems were modeled which represent tests of our hypothesis that the relative probability that a specific bond in a precursor will break will correlate with the length of the corresponding $\mathrm{C}-\mathrm{N}\left(\mathrm{H}^{+}\right)$bond in its conjugate acid. Noncage urils that were modeled included 1,3-dimethyl-2-imidizolidinone (5); 1,3-bis(BOC)-2-imidizolidinone (6); 2,4,6,8-tetrazabicyclo[3.3.0]octane-3,7-dione (7); 2,4,6,8tetramethyl-2,4,6,8-tetrazabicyclo[3.3.0]octane-3,7-dione (8); and a methylene-bridged tetramethyltetraza-bicyclo[3.3.0]octane-2,5-dione dimer (9). Equilibrium structures for these molecules are presented in Fig. 11, and Table 1 lists the lengths $\left(r_{e}\right)$ of selected bonds. 


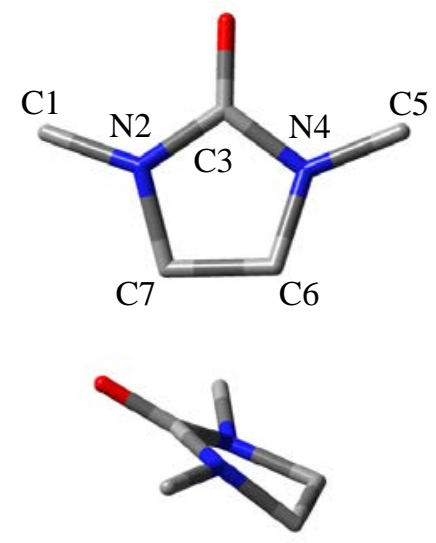

5

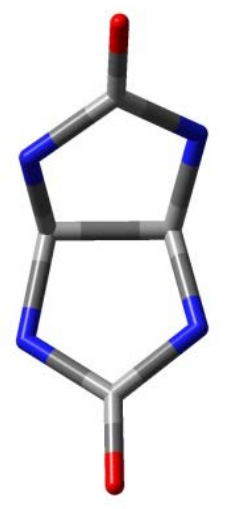

7

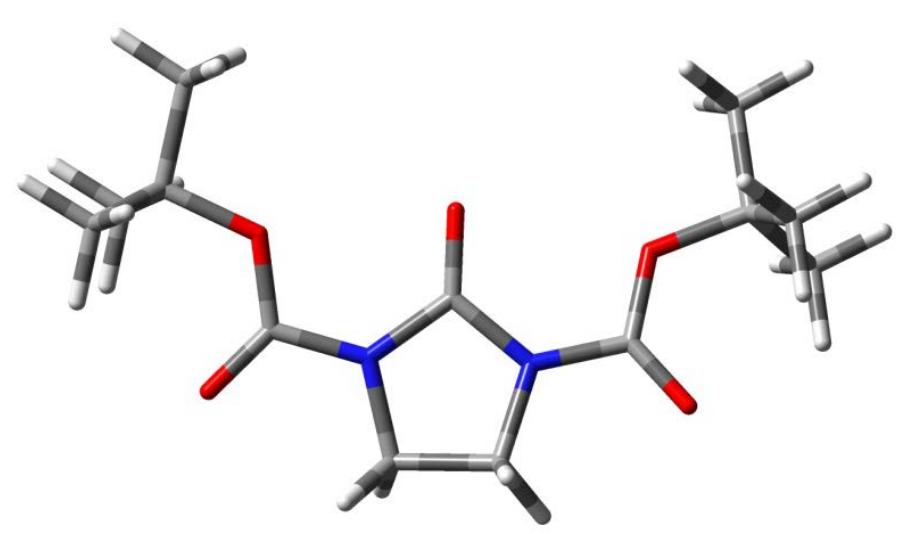

6

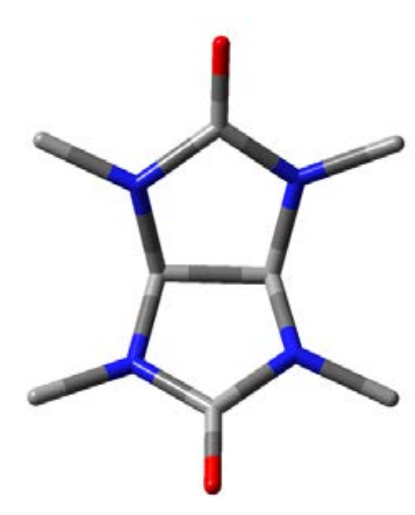

8(gss)

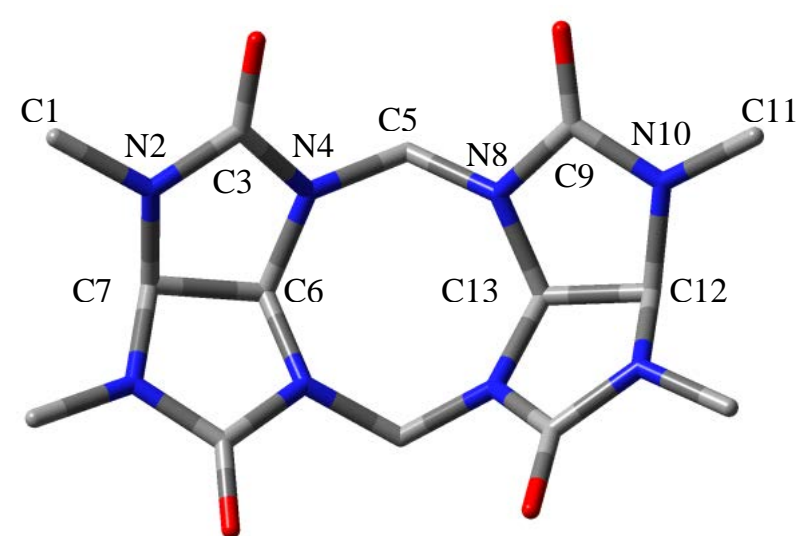

9

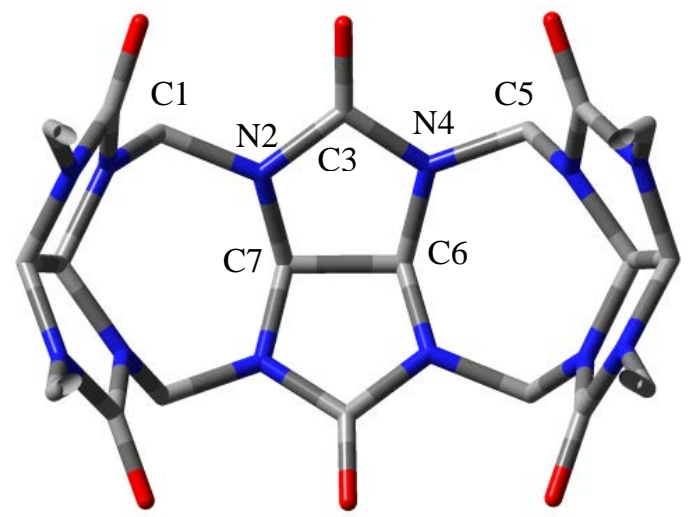

CB[5]

Fig. 11 Molecular structures of urils (H-atoms are not shown. CB[5] has been "Z-clipped.”) 
Table 1 Predicted bond lengths ( $r_{e}$ in angstroms) for noncage urils ${ }^{\mathrm{a}}$

\begin{tabular}{|l|c|c|c|c|c|c|}
\hline \multirow{2}{*}{ Bond } & 5 & 6 & \multicolumn{2}{c|}{8 8gss } & \multicolumn{2}{c|}{9} \\
\cline { 2 - 7 } & B3LYP & B3LYP & B3LYP & GED & B3LYP & XRC $^{\mathrm{b}}$ \\
\hline N2-C1 $\left(\mathrm{C}_{\mathrm{s}}\right)$ & 1.449 & 1.399 & 1.449 & 1.458 & 1.453 & 1.459 \\
\hline N2-C3 $\left(\mathrm{C}_{\mathrm{u}}\right)$ & 1.390 & 1.415 & 1.383 & 1.386 & 1.389 & 1.359 \\
\hline N4-C3 $\left(\mathrm{C}_{\mathrm{u}}\right)$ & 1.390 & 1.414 & 1.393 & 1.395 & 1.392 & 1.393 \\
\hline N4-C5 $\left(\mathrm{C}_{\mathrm{s} / \mathrm{b}}\right)$ & 1.449 & 1.399 & 1.453 & 1.462 & 1.444 & 1.448 \\
\hline N4-C6 $\left(\mathrm{C}_{\mathrm{c}}\right)$ & 1.457 & 1.467 & 1.458 & 1.467 & 1.443 & 1.451 \\
\hline N2-C7 $\left(\mathrm{C}_{\mathrm{c}}\right)$ & 1.457 & 1.467 & 1.443 & 1.453 & 1.456 & 1.449 \\
\hline C6-C7 & 1.538 & 1.532 & 1.562 & 1.576 & 1.563 & 1.560 \\
\hline N8-C5 $\left(\mathrm{C}_{\mathrm{b}}\right)$ & $\ldots$ & $\ldots$ & $\ldots$ & $\ldots$ & 1.451 & 1.448 \\
\hline N8-C9 $\left(\mathrm{C}_{\mathrm{u}}\right)$ & $\ldots$ & $\ldots$ & $\ldots$ & $\ldots$ & 1.399 & 1.382 \\
\hline N10-C9 $\left(\mathrm{C}_{\mathrm{u}}\right)$ & $\ldots$ & $\ldots$ & $\ldots$ & $\ldots$ & 1.381 & 1.379 \\
\hline N10-C11 $\left(\mathrm{C}_{\mathrm{s}}\right)$ & $\ldots$ & $\ldots$ & $\ldots$ & $\ldots$ & 1.449 & 1.461 \\
\hline N10-C12 $\left(\mathrm{C}_{\mathrm{c}}\right)$ & $\ldots$ & $\ldots$ & $\ldots$ & $\ldots$ & 1.441 & 1.448 \\
\hline N8-C13 $\left(\mathrm{C}_{\mathrm{c}}\right)$ & $\ldots$ & $\ldots$ & $\ldots$ & $\ldots$ & 1.456 & 1.449 \\
\hline C12-C13 & $\ldots$ & $\ldots$ & $\ldots$ & $\ldots$ & 1.563 & 1.560 \\
\hline
\end{tabular}

${ }^{a}$ Atom labels refer to Fig. 11. B3LYP = B3LYP/6-31+G(d,p).

${ }^{\mathrm{b}} r_{g}$ (in $\AA$ ) reported by Atavin et al. (2005). GED = gas-phase electron diffractometry.

'Stancl et al. (2008).

5 is a common dipolar, aprotic solvent that is employed for extractions. It has been the subject of numerous studies. (SciFinder listed more than 2,300 references for it.) However, we could find no measurement-based characterizations of its molecular structure. Only one equilibrium conformer was produced by the B3LYP/6-31+G(d,p) model. In it the (electron) lone pairs associated with the $2 \mathrm{~N}$-atoms are antiparallel to one another. Describing postulated geometries for the 5-membered rings in 8, Atavin et al. (2005) referred to such configurations as "semichair," and that label/description has been adopted for them in this report as well. An attempt was made to model a configuration in which the lone pairs are parallel to one another. (Such configurations are henceforth referred to as “envelopes.”) The optimization performed with this starting structure converged to the semichair conformer. The semichair conformer was also the only converged solution produced for 6 .

The synthesis of 8 was reported in 1887 (Franchimont and Klobbie 1887). A daytime tranquilizer that is referred to as "mebicar" in Russian literature, its molecular structure has been characterized by Atavin et al. (2005) on the basis of gas-phase electron diffractometry (GED) data and guidance provided by a B3LYP/6-31G(d) model. Atavin et al. considered 3 different equilibrium conformers as bases for analyzing their GED data. Of the 3 , they found a "gauchesemichair-semichair" (gss) configuration to be superior to the other 2 with respect to producing a self-consistent analysis. The term gauche refers to the orientation of the H-atoms bonded to the $\mathrm{C}_{\mathrm{c}}$-atoms (C7 and C8). Structures with a trans orientation of these atoms can also be postulated.

Only one gauche conformer of $\mathbf{8}$ was found, and its structure corresponded to the semichairsemichair configuration (8gss) deduced by Atavin et al. (2005). A trans conformer was also modeled, but it was found to be $24 \mathrm{kcal} / \mathrm{mol}$ higher in energy than $\mathbf{8 g s s}$. Therefore, it is not 
discussed further. All the bond lengths $\left(r_{e}\right)$ produced for 8gss by the B3LYP/6-31+G(d,p) model are shorter than the corresponding $r_{g}$ value determined by Atavin et al., but all corresponding values are within $0.010 \AA$ of one another. As such, the results indicate the validity of the B3LYP/6-31+G(d,p) model for this application.

Tetramethylglycoluril dimer (9) has been isolated, and a molecular structure has been established for it in the solid state on the basis of X-ray crystallography (XRC) data (Stancl et al. 2008). The structure observed was C-shaped rather than S-shaped, and the molecules were found to be nested. Interestingly, all the 5-membered rings were found to have the envelope configuration.

Both C- and S-shaped conformers of 9 were modeled in this work. The $H(298)$ value for the Sshaped conformer was found to be only $0.5 \mathrm{kcal} / \mathrm{mol}$ higher than that of the C-shaped conformer. Bond lengths predicted for the (gas-phase) C-shaped conformer are in good agreement with bond lengths determined by Stancl et al. (2008). As shown in Table 1, the C-N bonds associated with $\mathrm{N}$-atoms that are not bonded to the $\mathrm{C}$-atom of a methylene bridge $\left(\mathrm{C}_{\mathrm{b}}\right)$ (i.e., N2 and N10) are similar in length to their corresponding bond in 8gss. In contrast, the $\mathrm{C}-\mathrm{N}$ bonds associated with $\mathrm{N}$-atoms that are bonded to $\mathrm{C}_{\mathrm{b}}$ (i.e., N4 and N8) are considerably shorter than their corresponding bond in 8gss.

\subsubsection{Cucurbituril Structures: Geometric Parameters and Relative Energies}

Selected bond lengths and $H(298)$ /monomer unit values for the cucurbiturils discussed in this report are shown in Table 2. The labels employed in the table refer to Fig. 11 . Bond lengths derived from XRC data have been published for numerous $\mathrm{CB}[\mathrm{n}]$ hydrates, and results for representative examples of hydrates of $\mathrm{CB}[5]$ and $\mathrm{CB}[6]$ are included for comparison.

Table 2 Predicted bond lengths ${ }^{\mathrm{a}}$ ( $r_{e}$ in angstroms) and gas-phase $H(298) /$ monomer unit values ${ }^{\mathrm{b}}$ for cucurbiturils

\begin{tabular}{|c|c|c|c|c|c|c|c|}
\hline \multirow{2}{*}{ Parameter } & \multicolumn{2}{|c|}{ CB[5] } & \multicolumn{2}{|c|}{ CB[6] } & \multirow{2}{*}{$\begin{array}{c}\text { CB[7] } \\
\text { B3LYP }\end{array}$} & \multirow{2}{*}{$\begin{array}{c}\text { CB[8] } \\
\text { B3LYP }\end{array}$} & \multirow{2}{*}{$\begin{array}{l}\text { CB[10] } \\
\text { B3LYP }\end{array}$} \\
\hline & B3LYP & XRC $^{\mathrm{c}}$ & B3LYP & $X_{R C^{d}}$ & & & \\
\hline $\mathrm{N} 2-\mathrm{C} 1\left(\mathrm{C}_{\mathrm{b}}\right)$ & 1.453 & 1.481 & 1.450 & 1.402 & 1.448 & 1.449 & 1.447 \\
\hline $\mathrm{N} 2-\mathrm{C} 3\left(\mathrm{C}_{\mathrm{u}}\right)$ & 1.395 & 1.373 & 1.394 & 1.363 & 1.394 & 1.395 & 1.394 \\
\hline $\mathrm{N} 4-\mathrm{C} 3\left(\mathrm{C}_{\mathrm{u}}\right)$ & 1.394 & 1.373 & 1.392 & 1.383 & 1.392 & 1.392 & 1.394 \\
\hline N4-C5 $\left(C_{b}\right)$ & 1.447 & 1.481 & 1.447 & 1.471 & 1.446 & 1.446 & 1.448 \\
\hline N4-C6 $\left(\mathrm{C}_{c}\right)$ & 1.445 & 1.432 & 1.444 & 1.458 & 1.443 & 1.444 & 1.448 \\
\hline $\mathrm{N} 2-\mathrm{C} 7\left(\mathrm{C}_{\mathrm{c}}\right)$ & 1.453 & 1.432 & 1.452 & 1.441 & 1.452 & 1.452 & 1.448 \\
\hline C6-C7 & 1.571 & 1.639 & 1.569 & 1.533 & 1.567 & 1.566 & 1.565 \\
\hline$H(298) /[\mathrm{n}]^{\mathrm{e}}$ & -601.6321 & & -601.6355 & & -601.6366 & -601.6369 & -601.6365 \\
\hline$\Delta H(298) /[\mathrm{n}]^{\mathrm{f}}$ & 3.0 & & 0.9 & & 0.2 & 0.0 & 0.2 \\
\hline
\end{tabular}

${ }^{a}$ Atom labels refer to Fig. 11. The $r_{e}$ values are based on B3LYP/6-31+G(d,p) results.

${ }^{\mathrm{b}} H(298)$ values are based on electronic energies calculated with the B3LYP/6-31+G(d,p) model and ZPVEs derived from results obtained with the B3LYP/6-31G(d) model.

${ }^{\mathrm{C}} \mathrm{CB}$ [5] bis(hydrochloric acid) hydrate: Bardelang et al. (2008).

${ }^{\mathrm{d}} \mathrm{CB}[6]$ hydrate: Bardelang et al. (2011).

${ }^{\mathrm{e}}$ hartrees.

${ }^{\mathrm{f}}$ Compared to CB[8] (in kilocalories per mole). 
Based on the results for $\mathbf{8}$, all the starting structures for the $\mathrm{CB}[\mathrm{n}]$ geometry optimizations were built with glycouril substructures having semichair-semichair configurations. However, the 5-membered (sub)rings produced by the optimizations were relatively flat, making the distinction essentially irrelevant. Otherwise, parameters found for the glycouril substructures within the cucurbiturils were very similar to those found for $\mathbf{8}$. All the lengths of the bonds in the cucurbiturils were within $0.013 \AA$ of the length of their corresponding bond in $\mathbf{8}$. In contrast, some significant differences between modeled and XRC-based bond lengths were observed. For example, a 0.068- $\AA$ difference between the computed and XRC-based values for the length of the $\mathrm{C} 6-\mathrm{C} 7$ bond in $\mathrm{CB}[5]$ is observed. However, because the XRC results are for hydrates, and the model produced results for $\mathbf{1 1}$ that were comparable to XRC-based values, the discrepancies were not considered a negative indication of the model's validity for the application.

It was surprising to find that $\mathrm{CB}[8]$ had the lowest estimated $H(298) /[\mathrm{n}]$ value. $\mathrm{CB}[6]$ is the most prevalent cucurbituril and therefore was expected to have this distinction.

\subsubsection{N-Protonation of Urils}

As mentioned in the introduction, we were interested in establishing a simple method for predicting the relative likelihood of the breaking of the $3 \mathrm{C}-\mathrm{N}$ bond types in the cucurbiturils and postulated that the lengths of $\mathrm{C}-\mathrm{N}\left(\mathrm{H}^{+}\right)$bonds in their conjugate acids might provide an indication. Results produced for the (N-protonated) conjugate acids of noncage urils are presented in Table 3. The results for $\mathbf{6}-\mathbf{H}^{+}$are considered particularly relevant with respect to this issue. As already stated, Flynn et al. (1983) produced bis(BOC)ethylenediamine from $\mathbf{6}$. As such, the system represents a test of our hypothesis, and, indeed, the longest $\mathrm{C}-\mathrm{N}\left(\mathrm{H}^{+}\right)$bond in $\mathbf{6}-\mathbf{H}^{+}$ proved to be the one corresponding to the $\mathrm{C}_{\mathrm{u}}-\mathrm{N}$ bond of $\mathbf{6}$. To further test the hypothesis, we note that similar $\mathrm{C}-\mathrm{N}\left(\mathrm{H}^{+}\right)$bond length trends are found in $\mathbf{5}-\mathbf{H}^{+}$. Therefore, if the hypothesis is valid, di(methyl)ethylenediamine should be able to be produced from the hydrolysis of 5 .

Table 3 Predicted bond lengths ${ }^{\mathrm{a}}$ ( $r_{e}$ in angstroms) for N-protonated noncage urils and proton affinities ${ }^{\mathrm{b}}$ (in kilocalories per mole) for their conjugate bases: B3LYP/6-31+G(d,p) results

\begin{tabular}{|l|c|c|c|c|c|c|c|c|}
\hline \multicolumn{1}{|c|}{ Parameter } & $\mathbf{5 - H}^{+}$ & $\mathbf{6 - H ^ { + }}$ & \multicolumn{2}{c|}{$\mathbf{8 g s s}^{+} \mathbf{H}^{+}$} & \multicolumn{4}{c|}{$\mathbf{9 - H}^{+}$} \\
\hline Proton site & $\mathrm{N} 2$ & $\mathrm{~N} 2$ & $\mathrm{~N} 2$ & $\mathrm{~N} 4$ & $\mathrm{~N} 2$ & $\mathrm{~N} 4$ & $\mathrm{~N} 8$ & N10 \\
\hline Proton affinity & 210 & 202 & 208 & 206 & 209 & 202 & 210 & 208 \\
\hline N2-C1 $\left(\mathrm{C}_{\mathrm{s}}\right)$ & $\mathbf{1 . 5 0 2}$ & $\mathbf{1 . 5 4 1}$ & 1.502 & 1.469 & $\mathbf{1 . 4 9 9}$ & 1.467 & 1.458 & 1.456 \\
\hline N2-C3 $\left(\mathrm{C}_{\mathrm{u}}\right)$ & $\mathbf{1 . 5 7 3}$ & $\mathbf{1 . 6 0 3}$ & $\mathbf{1 . 5 6 0}$ & 1.342 & $\mathbf{1 . 5 6 0}$ & 1.338 & 1.362 & 1.370 \\
\hline N2-C7 $\left(\mathrm{C}_{\mathrm{c}}\right)$ & $\mathbf{1 . 5 0 5}$ & $\mathbf{1 . 4 9 4}$ & $\mathbf{1 . 5 5 8}$ & 1.458 & $\mathbf{1 . 5 5 7}$ & 1.460 & 1.461 & 1.446 \\
\hline N4-C3 $\left(\mathrm{C}_{\mathrm{u}}\right)$ & 1.336 & 1.351 & 1.341 & $\mathbf{1 . 5 4 2}$ & 1.345 & $\mathbf{1 . 5 3 8}$ & 1.421 & 1.413 \\
\hline N4-C5 $\left(\mathrm{C}_{\mathrm{s}} / \mathrm{C}_{\mathrm{b}}\right)$ & 1.467 & 1.457 & 1.469 & 1.508 & 1.489 & $\mathbf{1 . 6 1 5}$ & 1.404 & 1.424 \\
\hline N4-C6 $\left(\mathrm{C}_{\mathrm{c}}\right)$ & 1.464 & 1.472 & 1.461 & $\mathbf{1 . 5 8 2}$ & 1.458 & $\mathbf{1 . 5 6 0}$ & 1.454 & 1.461 \\
\hline N8-C5 $\left(\mathrm{C}_{\mathrm{s}} / \mathrm{C}_{\mathrm{b}}\right)$ & $\ldots$ & $\ldots$ & $\ldots$ & $\ldots$ & 1.423 & 1.388 & $\mathbf{1 . 5 5 1}$ & 1.489 \\
\hline N8-C9 $\left(\mathrm{C}_{\mathrm{u}}\right)$ & $\ldots$ & $\ldots$ & $\ldots$ & $\ldots$ & 1.413 & 1.419 & $\mathbf{1 . 5 4 6}$ & 1.346 \\
\hline N8-C13 $\left(\mathrm{C}_{\mathrm{c}}\right)$ & $\ldots$ & $\ldots$ & $\ldots$ & $\ldots$ & 1.461 & 1.453 & $\mathbf{1 . 5 4 6}$ & 1.455 \\
\hline N10-C9 $\left(\mathrm{C}_{\mathrm{u}}\right)$ & $\ldots$ & $\ldots$ & $\ldots$ & $\ldots$ & 1.369 & 1.359 & 1.346 & $\mathbf{1 . 5 5 0}$ \\
\hline N10-C11 $\left(\mathrm{C}_{\mathrm{s}}\right)$ & $\ldots$ & $\ldots$ & $\ldots$ & $\ldots$ & 1.456 & 1.456 & 1.468 & $\mathbf{1 . 5 0 9}$ \\
\hline N10-C12 $\left(\mathrm{C}_{\mathrm{c}}\right)$ & $\ldots$ & $\ldots$ & $\ldots$ & $\ldots$ & 1.447 & 1.471 & 1.459 & $\mathbf{1 . 5 7 6}$ \\
\hline
\end{tabular}

${ }^{\mathrm{a} A t o m}$ labels refer to Fig. 11.

${ }^{\mathrm{b}} H(\mathrm{X}, 298)-H\left(\mathrm{X}-\mathrm{H}^{+}, 298\right)$. 
The $\mathrm{C}-\mathrm{N}\left(\mathrm{H}^{+}\right)$bond lengths found in $\mathbf{8}-\mathbf{H}^{+}$were somewhat different than the lengths of the corresponding bonds in $\mathbf{5}-\mathbf{H}^{+}$and $\mathbf{6}-\mathbf{H}^{+}$. Most notably, the lengths of the $\mathrm{C}_{\mathrm{c}}-\mathrm{N}\left(\mathrm{H}^{+}\right)$bonds of the two 8gss- $\mathbf{H}^{+}$structures that were modeled were comparable to or greater than the lengths of the $\mathrm{C}_{\mathrm{u}}-\mathrm{N}\left(\mathrm{H}^{+}\right)$bonds. Based on our hypothesis, these results suggest that the $\mathrm{C}_{\mathrm{c}}-\mathrm{N}$ bonds are as likely to break as the $\mathrm{C}_{\mathrm{u}}-\mathrm{N}$ bonds. An experimentally based study of the hydrolysis of $\mathbf{8}$ that confirmed or refuted this prediction would therefore be of interest.

In most respects, the C-N( $\left.\mathrm{H}^{+}\right)$bond length trends found in $\mathbf{9 - \mathbf { H } ^ { + }}$ are similar to those found in $\mathbf{8}$ $\mathbf{H}^{+}$. Regardless of the protonation site, the $\mathrm{C}_{\mathrm{c}}-\mathrm{N}\left(\mathrm{H}^{+}\right)$and $\mathrm{C}_{\mathrm{u}}-\mathrm{N}\left(\mathrm{H}^{+}\right)$bonds were comparable in length. When protonated at N2 and N10 (i.e., the N-atoms bonded to $-\mathrm{CH}_{3}$ groups), the $\mathrm{C}_{\mathrm{c}}-\mathrm{N}\left(\mathrm{H}^{+}\right)$ and $\mathrm{C}_{\mathrm{u}}-\mathrm{N}\left(\mathrm{H}^{+}\right)$bonds were significantly longer than the $\left(\mathrm{H}_{3}\right) \mathrm{C}_{\mathrm{s}}-\mathrm{N}\left(\mathrm{H}^{+}\right)$bond. When protonated at $\mathrm{N} 4$, the $\mathrm{C}_{\mathrm{b}}-\mathrm{N}\left(\mathrm{H}^{+}\right)$bond was the longest. When protonated at the most energetically favored site (N8), all the resulting $\mathrm{C}-\mathrm{N}\left(\mathrm{H}^{+}\right)$bonds were approximately the same length. If our hypothesis is correct, the results suggest that $\mathbf{9}$ 's hydrolysis will not be regioselective.

Results produced for the (N-protonated) conjugate acids of the cucurbiturils are presented in Table 4. In all cases, the lengths of the $3 \mathrm{C}-\mathrm{N}\left(\mathrm{H}^{+}\right)$bond types are comparable. Thus, as was found for $\mathbf{9}$, the results suggest the hydrolysis of the cucurbiturils will not be regioselective. 
Table 4 Predicted bond lengths ${ }^{\mathrm{a}}$ ( $r_{e}$ in angstroms) for N-protonated cucurbiturils and proton affinities ${ }^{\mathrm{b}}$ (in kilocalories per mole) for their conjugate bases

\begin{tabular}{|c|c|c|c|c|c|c|c|c|c|c|}
\hline Parameter & \multicolumn{2}{|c|}{$\mathbf{C B}[5]-\mathbf{H}^{+}$} & \multicolumn{2}{|c|}{$\mathrm{CB}[6]-\mathrm{H}^{+}$} & \multicolumn{2}{|c|}{$\mathbf{C B}[7]-\mathbf{H}^{+}$} & \multicolumn{2}{|c|}{$\mathbf{C B}[8]-\mathbf{H}^{+}$} & \multicolumn{2}{|c|}{$\mathrm{CB}[10]-\mathrm{H}^{+}$} \\
\hline Proton site & N2 & N4 & N2 & N4 & $\mathrm{N} 2$ & N4 & $\mathrm{N} 2$ & $\mathrm{~N} 4$ & $\mathrm{~N} 2$ & N4 \\
\hline Proton affinity & 212 & 207 & 214 & 204 & 214 & 214 & 214 & 214 & 214 & 214 \\
\hline N2-C1 $\left(\mathrm{C}_{\mathrm{b}}\right)$ & 1.555 & 1.490 & 1.545 & 1.490 & 1.539 & 1.491 & 1.535 & 1.489 & 1.533 & 1.485 \\
\hline $\mathrm{N} 2-\mathrm{C} 3\left(\mathrm{C}_{\mathrm{u}}\right)$ & 1.560 & 1.342 & 1.559 & 1.343 & 1.558 & 1.351 & 1.558 & 1.350 & 1.557 & 1.349 \\
\hline N2-C7 $\left(C_{c}\right)$ & 1.535 & 1.472 & 1.541 & 1.473 & 1.544 & 1.458 & 1.544 & 1.457 & 1.541 & 1.457 \\
\hline N4-C3( $\left.\mathrm{C}_{\mathrm{u}}\right)$ & 1.353 & 1.561 & 1.352 & 1.562 & 1.351 & 1.559 & 1.350 & 1.558 & 1.349 & 1.557 \\
\hline N4-C5 $\left(C_{b}\right)$ & 1.489 & 1.578 & 1.492 & 1.576 & 1.491 & 1.537 & 1.489 & 1.536 & 1.485 & 1.533 \\
\hline N4-C6(C $\left.C_{c}\right)$ & 1.461 & 1.536 & 1.460 & 1.536 & 1.458 & 1.544 & 1.457 & 1.544 & 1.457 & 1.542 \\
\hline
\end{tabular}

${ }^{a}$ Atom labels refer to Fig. 11. B3LYP/6-31+G(d,p) results.

${ }^{\mathrm{b}} H(\mathrm{X})-H\left(\mathrm{X}-\mathrm{H}^{+}\right)$derived from B3LYP/6-31+G(d,p) electronic energies and ZPVEs derived from B3LYP/6-31G(d) results. 


\subsubsection{Cucurbituril Hydrolysis Targets}

Although the results of the previous section indicated that it would be difficult to design a system that would regioselectively hydrolyze cucurbiturils, we modeled targeted products. (It was, in fact, a step toward building the targeted PCNAs.) Figure 12 shows configurations for the targets for the hydrolysis of $\mathrm{CB}[5]$ and $\mathrm{CB}[6]$. Labeled $\mathbf{1 0}$ and 11, respectively, for each molecule, 2 conformers were produced from starting geometries in which all the 8-membered rings were configured to resemble $\beta$-HMX. In the first (10a and 11a), the molecules were more symmetric than in the second (10b and 11b). A third conformer was also built for each. In them (10c and 11c), all the 8-membered rings were configured to resemble $\delta$-HMX. Of the 6 structures, only 10c retained the high degree of symmetry built into its starting geometry.

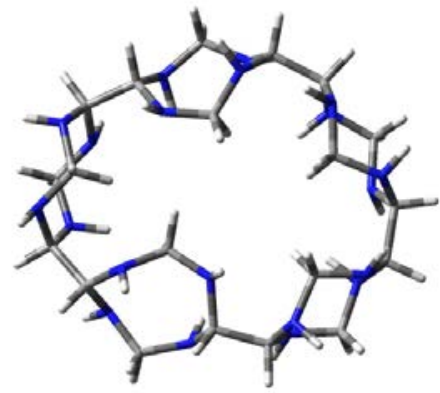

10a

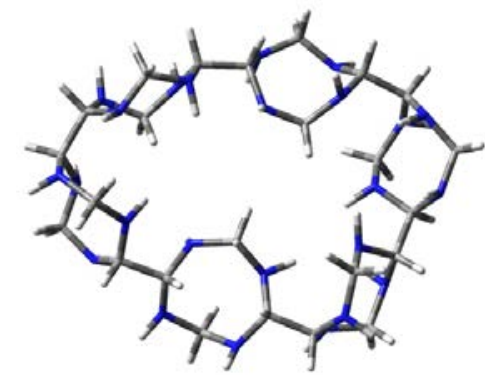

11a

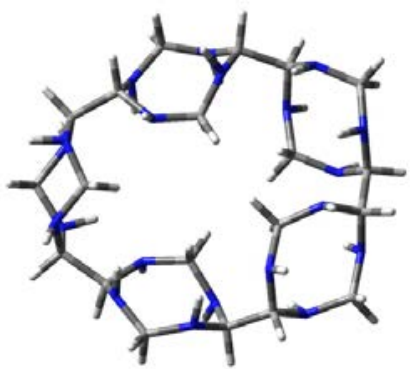

10b

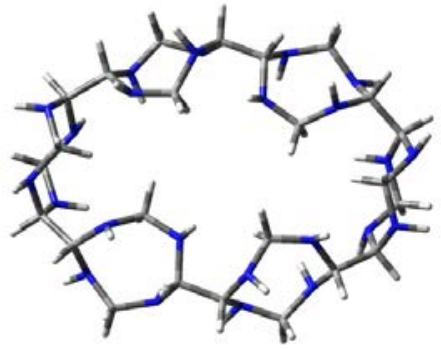

11b

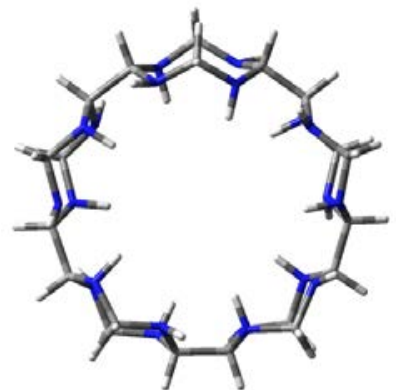

10c

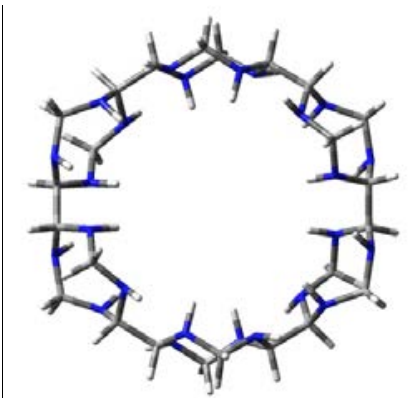

11c

Fig. 12 Molecular structures of targets of the hydrolysis of $\mathrm{CB}[5](\mathbf{1 0 a}-\mathbf{c})$ and $\mathrm{CB}[6](\mathbf{1 1 a}-\mathbf{c})$

The lowest energy conformer of $\mathbf{1 0}$ was 10a while the lowest energy conformer of $\mathbf{1 1}$ was 11c. Table 5 shows the longest bond of each type for 10a and 11c. The lengths of the C-N bonds are comparable to those found for other aminals, but the C-C bonds are considerably longer than others found in this study. As such, the results suggest that the stabilities of these compounds could be an issue.

Table 5 Predicted bond lengths ( $r_{e}$ in angstroms) for cucurbituril hydrolysis targets $\mathbf{1 0 a}$ and $\mathbf{1 1} \mathbf{c}^{\mathrm{a}}$

\begin{tabular}{|l|c|c|}
\hline \multicolumn{1}{|c|}{ Bond } & 10a & 11c \\
\hline $\mathrm{N}-\mathrm{CH}_{2}$ & 1.475 & 1.470 \\
\hline $\mathrm{N}-\mathrm{CH}$ & 1.483 & 1.479 \\
\hline $\mathrm{C}-\mathrm{C}$ & 1.602 & 1.604 \\
\hline
\end{tabular}

${ }^{a}$ Refer to Fig. 12. The length of the longest bond of each type is reported. 


\subsection{Findings Related to Scheme I}

\subsubsection{Noncage Aminal Equilibrium Structures: Geometric Parameters}

Structures for aminals are presented in Fig. 13, and Table 6 lists the lengths of selected bonds in noncage varieties. The length found for all the C-N bonds in HMTA (1.477 $\AA$ ) is included for comparison.

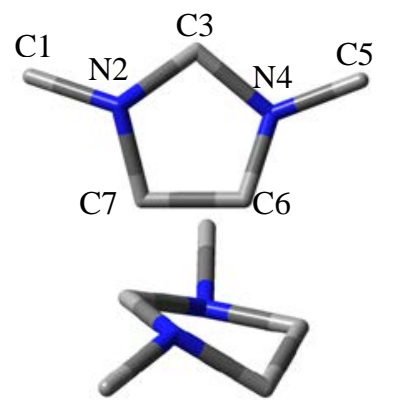

12s

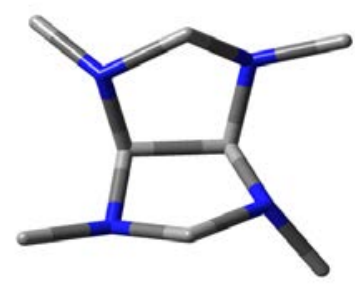

14

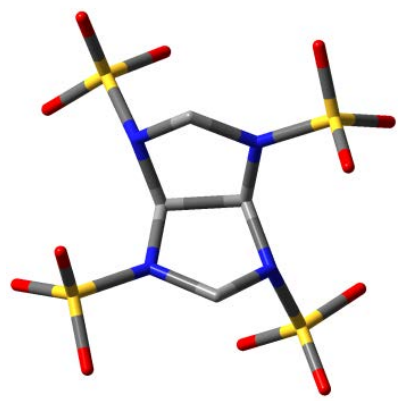

17

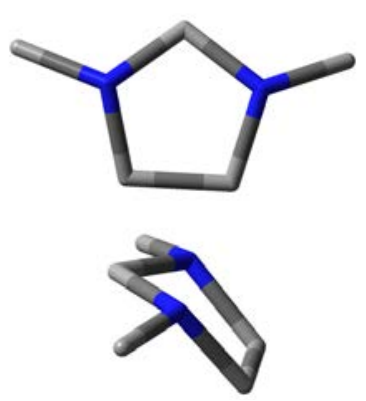

12e

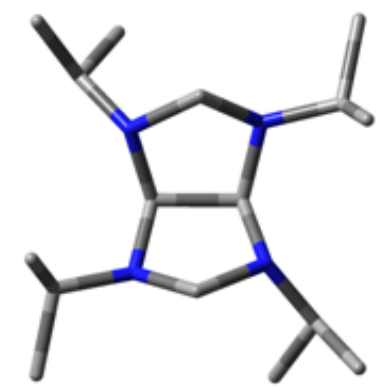

15

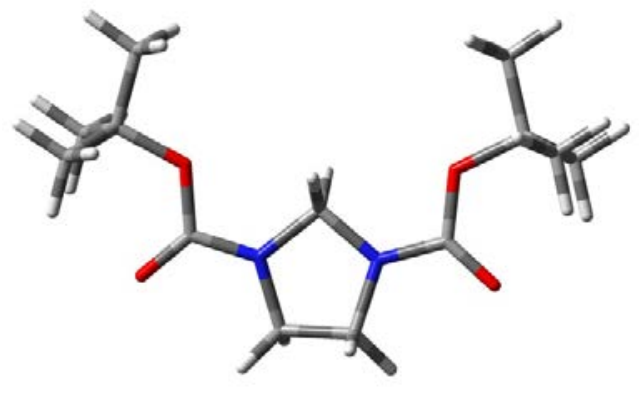

13

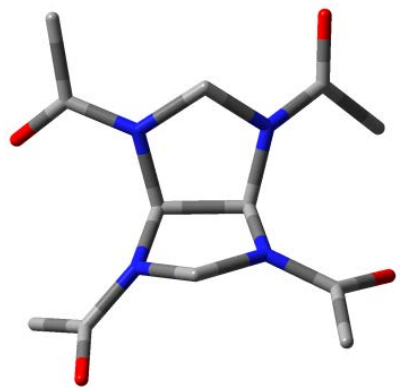

16

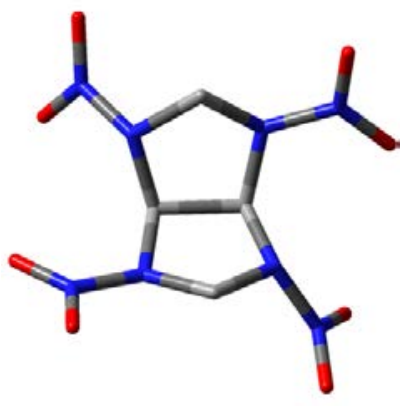

18

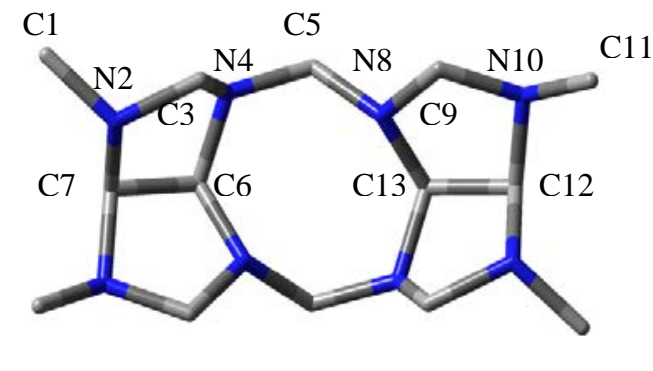

19

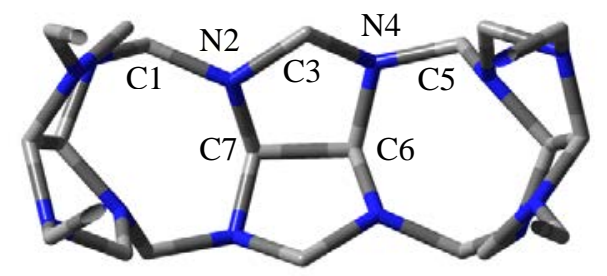

$\mathrm{CB}[5] \mathrm{A}$

Fig. 13 Molecular structures of aminals (H-atoms are not shown. CB[5]A is "Z-clipped”.) 
Table 6 Predicted bond lengths ( $r_{e}$ in angstroms) for noncage aminals ${ }^{\mathrm{a}}$

\begin{tabular}{|c|c|c|c|c|c|c|c|c|c|c|c|}
\hline \multirow{2}{*}{ Bond } & HMTA & $12 \mathrm{~s}$ & $12 e$ & 13 & 14 & 15 & \multicolumn{2}{|c|}{16} & 17 & 18 & 19 \\
\hline & B3LYP & B3LYP & B3LYP & B3LYP & B3LYP & B3LYP & B3LYP & $\mathrm{XRC}^{\mathrm{C}}$ & B3LYP & B3LYP & B3LYP \\
\hline $\mathrm{N} 2-\mathrm{C} 1\left(\mathrm{C}_{\mathrm{s}}\right)$ & $1.477^{\mathrm{b}}$ & 1.451 & 1.450 & 1.363 & 1.462 & 1.479 & 1.375 & 1.352 & $\ldots$ & $\ldots$ & 1.462 \\
\hline N2-C3 $\left(\mathrm{C}_{\mathrm{u}}\right)$ & $\ldots$ & 1.468 & 1.453 & 1.462 & 1.464 & 1.464 & 1.468 & 1.460 & 1.461 & 1.461 & 1.469 \\
\hline N4-C3 $\left(\mathrm{C}_{\mathrm{u}}\right)$ & $\ldots$ & 1.468 & 1.455 & 1.462 & 1.465 & 1.463 & 1.456 & 1.465 & 1.476 & 1.472 & 1.463 \\
\hline N4-C5 $\left(\mathrm{C}_{\mathrm{s}}\right)$ & $\ldots$ & 1.451 & 1.450 & 1.364 & 1.454 & 1.469 & 1.390 & 1.364 & & & 1.456 \\
\hline N4-C6 $\left(\mathrm{C}_{\mathrm{c}}\right)$ & $\ldots$ & 1.463 & 1.473 & 1.463 & 1.455 & 1.452 & 1.452 & 1.449 & 1.475 & 1.460 & 1.457 \\
\hline $\mathrm{N} 2-\mathrm{C} 7\left(\mathrm{C}_{\mathrm{c}}\right)$ & $\ldots$ & 1.464 & 1.468 & 1.463 & 1.485 & 1.483 & 1.468 & 1.463 & 1.472 & 1.470 & 1.487 \\
\hline C6-C7 & $\ldots$ & 1.523 & 1.547 & 1.531 & 1.554 & 1.562 & 1.567 & 1.544 & 1.589 & 1.566 & 1.547 \\
\hline N8-C5 $\left(\mathrm{C}_{\mathrm{b}}\right)$ & $\ldots$ & $\ldots$ & $\ldots$ & $\ldots$ & $\ldots$ & $\ldots$ & $\ldots$ & $\ldots$ & $\ldots$ & $\ldots$ & 1.451 \\
\hline N8-C9 $\left(\mathrm{C}_{\mathrm{u}}\right)$ & $\ldots$ & $\ldots$ & $\ldots$ & $\ldots$ & $\ldots$ & $\ldots$ & $\ldots$ & $\ldots$ & $\ldots$ & $\ldots$ & 1.454 \\
\hline N10-C9 $\left(\mathrm{C}_{\mathrm{u}}\right)$ & $\ldots$ & $\ldots$ & $\ldots$ & $\ldots$ & $\ldots$ & $\ldots$ & $\ldots$ & $\ldots$ & $\ldots$ & $\ldots$ & 1.464 \\
\hline $\mathrm{N} 10-\mathrm{C} 11\left(\mathrm{C}_{\mathrm{s}}\right)$ & $\ldots$ & $\ldots$ & $\ldots$ & $\ldots$ & $\ldots$ & $\ldots$ & $\ldots$ & $\ldots$ & $\ldots$ & $\ldots$ & 1.453 \\
\hline $\mathrm{N} 10-\mathrm{C} 12\left(\mathrm{C}_{\mathrm{c}}\right)$ & $\ldots$ & $\ldots$ & $\ldots$ & $\ldots$ & $\ldots$ & $\ldots$ & $\ldots$ & $\ldots$ & $\ldots$ & $\ldots$ & 1.455 \\
\hline N8-C13 $\left(\mathrm{C}_{\mathrm{c}}\right)$ & $\ldots$ & $\ldots$ & $\ldots$ & $\ldots$ & $\ldots$ & $\ldots$ & $\ldots$ & $\ldots$ & $\ldots$ & $\ldots$ & 1.465 \\
\hline C12-C13 & $\ldots$ & $\ldots$ & $\ldots$ & $\ldots$ & $\ldots$ & $\ldots$ & $\ldots$ & $\ldots$ & $\ldots$ & $\ldots$ & 1.546 \\
\hline
\end{tabular}

${ }^{a}$ Atom labels refer to Fig. 13. For HMTA, see Fig. 4. B3LYP = B3LYP/6-31+G(d,p).

${ }^{\mathrm{b}}$ The lengths of all the C-N bonds in HMTA are the same.

${ }^{\mathrm{c}}$ Koppes et al. (1987). 
1,3-dimethylimidizolidine (12) and 2,4,6,8-tetramethyl-2,4,6,8-tetrazabicyclo[3.3.0]octane (14) were modeled to provide guidance in building starting $\mathrm{CB}[\mathrm{n}]$ A structures that would lead to low-energy conformers. 12 has been produced by reducing 5 with lithium aluminum hydride (Bates et al. 1986, Katritzky et al. 2007). Investigated as a potential hydrazine-alternative hypergolic fuel, 12 has also been previously studied via computationally based methods (McQuaid et al. 2005). It was stable enough to be shipped and experimentally tested without any particularly special handling procedures. It should be noted, however, that $\mathbf{1 2}$ has been observed to be hydrolytically unstable (2006 private communication with R Damavarapu; unreferenced, see "Notes").

In contrast to 5, and as found previously by McQuaid et al. (2005), semichair (12s) and envelope (12e) configurations were found for 12 . The $H(298)$ estimate for $12 \mathrm{~s}$ was $0.7 \mathrm{kcal} / \mathrm{mol}$ lower than the one found for 12e. As such, it is expected (based on Boltzmann statistics) that a gas-phase sample of 12 at $298 \mathrm{~K}$ will have measurable fractions of both $\mathbf{1 2 s}$ and 12e. With respect to establishing whether predicted bond lengths may be an indicator of an aminal's stability, it is noted that the lengths of all the C-N bonds in 12s and 12e are shorter than those in HMTA, and the compound has been observed to be stable at $298 \mathrm{~K}$.

14 has been synthesized by reducing 8 with lithium aluminum hydride (Nelsen and Hintz 1972, Koppes et al. 1987), but no characterizations of its molecular structure could be found. An attempt was made to obtain optimized geometries for 4 different gauche configurations of 14. Starting structures for the optimizations included a semichair-semichair, a semichair-envelope, and 2 different envelope-envelope configurations. However, only 2 converged solutions were obtained: one corresponding to the semichair-semichair configuration (14gss) and one corresponding to one of the envelope-envelope configurations. The $H(298)$ estimate for the envelope-envelope structure was $3.3 \mathrm{kcal} / \mathrm{mol}$ higher than the one computed for $\mathbf{1 4 g s s}$. That difference is more than 4 times larger than the difference between 12s and 12e and indicates that the concentration of the envelope-envelope structure in a gas-phase sample of $\mathbf{1 2}$ at room temperature will be negligible. (A trans configuration [14tss] was also modeled, and it was found to be approximately $19 \mathrm{kcal} / \mathrm{mol}$ higher in energy than 14gss.) Based on these results, it was anticipated that the lowest energy conformers of the cucurbitaminals would be composed exclusively of 2,4,6,8tetrazabicyclo[3.3.0]octane substructures having semichair-semichair configurations, and that was indeed found. Thus, the bond lengths found for $\mathbf{1 4 g s s}$ and $\mathbf{1 4 g s s}-\mathbf{H}^{+}$are the only ones considered in the discussion that follows.

Trying to develop precursors for the synthesis of 2,4,6,8-tetranitro-2,4,6,8-tetrazabicyclo[3.3.0]octane (18), which is commonly referred to as bicyclo-HMX, Koppes et al. (1987) also synthesized 2,4,6,8-tetraisopropyl-2,4,6,8-tetrazabicyclo[3.3.0]octane (15) and 2,4,6,8-acetyl-2,4,6,8tetrazabicyclo[3.3.0] octane (16). The latter's structure was characterized via (solid-state) XRC. There is fair agreement between the bond lengths of (gas-phase) $\mathbf{1 6}$ that were produced by the B3LYP/6-31+G(d,p) model and those derived from the XRC data. The largest discrepancy between the bond lengths established by the 2 methods is for the bond between a ring $\mathrm{N}$-atom 
and the acetyl substituent's C-atom $\left(\mathrm{C}_{\mathrm{s}}\right)$. Given the difference between the surrounding media for the 2 cases, the magnitude of the bond length difference $(0.026 \AA)$ is not considered a negative indication of the model's validity.

15 and 16 were also of interest because Koppes et al. noted that 15 had a much shorter storage life than 16 or 14. (17, which has been used as a precursor for 18, also presumably has a longer storage life than 15.) As such, the set afforded an opportunity to determine whether "subtle" correlations between (modeled) bond lengths and stability could be observed. Noting that none of 16's C-N bonds are longer than the C-N bonds in HTMA, we also note that two C-N bonds in 15 are approximately $0.016 \AA$ longer than the C-N bonds in HTMA. But only one is longer than the $\mathrm{C}-\mathrm{N}$ bonds found in $\mathbf{1 4}$, and the difference between them is negligible. Thus, it is difficult to conclude that the bond lengths of 14-16 correlate with the difference in storage lives these compounds exhibited (in neat form).

Finally, methylene bridged tetramethyltetraza-bicyclo[3.3.0]octane dimer (19) was modeled. No unusually long bond lengths were found. As shown in Table 7, the lengths of $\mathrm{C}-\mathrm{N}$ and $\mathrm{C}-\mathrm{C}$ bonds in $\mathbf{1 9}$ are comparable to the length of their corresponding bond in $\mathbf{1 4 .}$ 
Table 7 Predicted bond lengths ${ }^{\mathrm{a}}\left(r_{e}\right.$ in angstroms) for N-protonated noncage aminals $\left(\mathbf{1 2}-\mathbf{H}^{+} \mathbf{- 1 6}-\mathbf{H}^{+}\right)$and $\mathbf{H M T A}-\mathbf{H}^{+}$, and proton affinities ${ }^{\mathrm{b}}$ (in kilocalories per mole) for their conjugate bases: B3LYP/6-31+G(d,p) results

\begin{tabular}{|c|c|c|c|c|c|c|c|c|c|c|}
\hline Parameter & HMTA-H $^{+}$ & 12s-H ${ }^{+}$ & $12 \mathrm{e}-\mathrm{H}^{+}$ & $13-\mathrm{H}^{+}$ & \multicolumn{2}{|c|}{14 (gss)- $\mathrm{H}^{+}$} & \multicolumn{2}{|c|}{ 15-H ${ }^{+}$} & \multicolumn{2}{|c|}{$16-\mathrm{H}^{+}$} \\
\hline Proton site & $\ldots$ & N2/N4 & N2/N4 & $\mathrm{N} 2 / \mathrm{N} 4$ & N2 & N4 & $\mathrm{N} 2$ & N4 & N2 & N4 \\
\hline Proton affinity & 227 & 229 & 229 & 211 & 237 & 233 & 242 & 241 & 205 & 197 \\
\hline N2-C1 $\left(\mathrm{C}_{\mathrm{s}}\right)$ & . & 1.504 & 1.498 & 1.521 & 1.492 & 1.463 & 1.534 & 1.482 & 1.558 & 1.423 \\
\hline N2-C3 $\left(\mathrm{C}_{\mathrm{u}}\right)$ & $1.557^{\mathrm{C}}$ & 1.529 & 1.518 & 1.582 & 1.539 & 1.439 & 1.538 & 1.437 & 1.512 & 1.429 \\
\hline $\mathrm{N} 2-\mathrm{C} 7\left(\mathrm{C}_{\mathrm{c}}\right)$ & $\ldots$ & 1.542 & 1.536 & 1.530 & 1.574 & 1.455 & 1.574 & 1.455 & 1.533 & 1.455 \\
\hline N4-C3 $\left(\mathrm{C}_{\mathrm{u}}\right)$ & $\ldots$ & 1.435 & 1.434 & 1.413 & 1.426 & 1.516 & 1.427 & 1.510 & 1.442 & 1.527 \\
\hline N4-C5 $\left(\mathrm{C}_{\mathrm{s}}\right)$ & $\ldots$ & 1.465 & 1.465 & 1.421 & 1.471 & 1.496 & 1.489 & 1.525 & 1.407 & 1.541 \\
\hline N4-C6 $\left(\mathrm{C}_{\mathrm{c}}\right)$ & $\ldots$ & 1.462 & 1.466 & 1.463 & 1.489 & 1.594 & 1.484 & 1.678 & 1.479 & 1.625 \\
\hline C6-C7 & $\ldots$ & 1.533 & 1.542 & 1.555 & 1.561 & 1.543 & 1.565 & 1.536 & 1.549 & 1.563 \\
\hline
\end{tabular}

${ }^{\mathrm{a}}$ The atom labels for the aminals refer to Fig. 13. For HMTA, refer to Fig. 4.

${ }^{\mathrm{b}} H(\mathrm{X}, 298)-H\left(\mathrm{X}-\mathrm{H}^{+}, 298\right)$.

'The (modeled) lengths of the $3 \mathrm{C}-\mathrm{N}\left(\mathrm{H}^{+}\right)$bonds in $\mathrm{HMTA}-\mathrm{H}^{+}$are all the same. The lengths of all other $\mathrm{C}-\mathrm{N}$ bonds were less than $1.479 \AA$. 


\subsubsection{Cucurbitaminal Structures: Geometric Parameters and Relative Energies}

Predicted bond lengths and $H(298) /[\mathrm{n}]$ estimates for cucurbitaminals are shown in Table 8. For $\mathrm{CB}[5] \mathrm{A}, \mathrm{CB}[6] \mathrm{A}$, and $\mathrm{CB}[7] \mathrm{A}$, several different starting geometries were optimized. It was found that the lowest energy conformer produced for each system consisted of 2,4,6,8tetrazabicyclo[3.3.0] octane substructures that were exclusively in semichair-semichair configurations. (This is only possible when all such substructures have the same folding.) As found in the comparisons between the structures of the cucurbiturils and $\mathbf{8}$, all the lengths of the bonds in the cucurbitaminals were very similar to the length of their corresponding bond in $\mathbf{1 4 .}$ As such, the comparisons do not indicate that the $\mathrm{CB}[\mathrm{n}] \mathrm{A}$ will be unstable. But again, $\mathbf{1 5}$ is relatively unstable, and its modeled bond lengths were found to be comparable to 14's. Thus we reiterate that, despite being seemingly favorable, such results are no guarantee that the cucurbitaminals will be isolable.

Table 8 Predicted bond lengths ${ }^{\mathrm{a}}$ ( $r_{e}$ in angstroms) and gas-phase $H(298) /$ monomer unit estimates for cucurbitaminals and $\mathbf{3 1}$

\begin{tabular}{|l|c|c|c|c|c|c|}
\hline \multicolumn{1}{|c|}{ Parameter } & CB[5]A & CB[6]A & CB[7]A & CB[8]A & CB[10]A & 31 \\
\hline N2-C1 $\left(\mathrm{C}_{\mathrm{b}}\right)$ & 1.447 & 1.448 & 1.451 & 1.453 & 1.456 & $1.475^{\mathrm{d}}$ \\
\hline $\mathrm{N} 2-\mathrm{C} 3\left(\mathrm{C}_{\mathrm{u}}\right)$ & 1.447 & 1.451 & 1.455 & 1.457 & 1.461 & $\ldots$ \\
\hline $\mathrm{N} 4-\mathrm{C} 3\left(\mathrm{C}_{\mathrm{u}}\right)$ & 1.463 & 1.463 & 1.463 & 1.463 & 1.463 & $\ldots$ \\
\hline $\mathrm{N} 4-\mathrm{C} 5\left(\mathrm{C}_{\mathrm{b}}\right)$ & 1.463 & 1.459 & 1.456 & 1.455 & 1.453 & $\ldots$ \\
\hline $\mathrm{N} 4-\mathrm{C} 6\left(\mathrm{C}_{\mathrm{c}}\right)$ & 1.464 & 1.461 & 1.458 & 1.456 & 1.452 & $\ldots$ \\
\hline $\mathrm{N} 2-\mathrm{C} 7\left(\mathrm{C}_{\mathrm{c}}\right)$ & 1.457 & 1.461 & 1.466 & 1.469 & 1.474 & $\ldots$ \\
\hline $\mathrm{C} 6-\mathrm{C} 7$ & 1.551 & 1.548 & 1.545 & 1.544 & 1.543 & 1.552 \\
\hline \multicolumn{7}{|l|}{} \\
\hline$H(298) /[\mathrm{n}]^{\mathrm{b}}$ & -453.4632 & -453.4662 & -453.4665 & -453.4660 & -453.4645 & $\ldots$ \\
\hline$\Delta H(298) /[\mathrm{n}]^{\mathrm{c}}$ & 2.1 & 0.2 & 0.0 & 0.3 & 1.2 & $\ldots$ \\
\hline
\end{tabular}

${ }^{\mathrm{a}}$ The atom labels for the cucurbitaminals refer to Fig. 13. For 31, refer to Fig. 19.

bhartrees.

${ }^{\mathrm{c}}$ Compared to CB[7]A (in kilocalories per mole).

${ }^{\mathrm{d}}$ The (modeled) lengths of all the C-N bonds in $\mathbf{3 1}$ are essentially the same.

Of the cucurbitaminals that were modeled, CB[7]A has the lowest estimated $H(298) /[\mathrm{n}]$. The $H(298) /[\mathrm{n}]$ values found for CB[6]A and CB[8]A, however, are very similar.

\subsubsection{N-Protonation of Aminals}

As mentioned in the introduction, Koppes et al. speculated that N-protonation of $\mathbf{1 5}$ would induce the $\mathrm{C}_{\mathrm{c}}-\mathrm{N}$ bond to break. Equilibrium geometries for the ( $\mathrm{N}$-protonated) conjugate acids of aminals were modeled to test (and suggest tests of) our hypothesis that the lengths of the $\mathrm{C}-\mathrm{N}\left(\mathrm{H}^{+}\right)$bonds would indicate which bonds would preferentially break under acid nitrolysis conditions. Modeling results for noncage aminals are shown in Tables 7 and 9. 
Table 9 Predicted bond lengths ${ }^{\mathrm{a}}\left(r_{e}\right.$ in angstroms) for N-protonated noncage aminals $\left(\mathbf{1 7 - \mathbf { H } ^ { + }}\right.$ and $\mathbf{1 9 -}$ $\mathbf{H}^{+}$) and proton affinities ${ }^{\mathrm{b}}$ (in kilocalories per mole) for their corresponding conjugate base: B3LYP/6-31+G(d,p) results

\begin{tabular}{|c|c|c|c|c|c|c|c|}
\hline Parameter & \multicolumn{3}{|c|}{$17-\mathbf{H}^{+}$} & \multicolumn{4}{|c|}{$19-\mathrm{H}^{+}$} \\
\hline Proton site & $\mathrm{N} 2$ & N4 & $\mathrm{O}$ & $\mathrm{N} 2$ & $\mathrm{~N} 4$ & N8 & N10 \\
\hline Proton affinity & 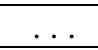 & $\ldots$ & $\ldots$ & 239 & 237 & 241 & 236 \\
\hline $\mathrm{N} 2-\mathrm{C} 1\left(\mathrm{C}_{\mathrm{s}}\right)$ & & & & 1.484 & 1.469 & 1.466 & 1.463 \\
\hline $\mathrm{N} 2-\mathrm{C} 3\left(\mathrm{C}_{\mathrm{u}}\right)$ & 1.495 & 1.440 & 1.475 & 1.495 & 1.438 & 1.455 & 1.462 \\
\hline $\mathrm{N} 2-\mathrm{C} 7\left(\mathrm{C}_{\mathrm{c}}\right)$ & 1.539 & 1.481 & 1.455 & 1.802 & 1.492 & 1.482 & 1.485 \\
\hline $\mathrm{N} 4-\mathrm{C} 3\left(\mathrm{C}_{\mathrm{u}}\right)$ & 1.438 & 1.529 & 1.470 & 1.443 & 1.518 & 1.478 & 1.467 \\
\hline N4-C5 $\left(\mathrm{C}_{\mathrm{b}}\right)$ & & & . & 1.476 & 1.570 & 1.413 & 1.434 \\
\hline $\mathrm{N} 4-\mathrm{C} 6\left(\mathrm{C}_{\mathrm{c}}\right)$ & 1.465 & 1.576 & 1.486 & 1.455 & 1.574 & 1.456 & 1.452 \\
\hline N8 C5 $\left(C_{b}\right)$ & $\ldots$ & $\ldots$ & $\ldots$ & 1.434 & 1.391 & 1.561 & 1.474 \\
\hline N8-C9 $\left(C_{u}\right)$ & $\ldots$ & $\ldots$ & $\ldots$ & 1.464 & 1.467 & 1.504 & 1.417 \\
\hline $\mathrm{N} 8-\mathrm{C} 13\left(\mathrm{C}_{\mathrm{c}}\right)$ & 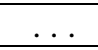 & $\ldots$ & $\ldots$ & 1.452 & 1.487 & 1.635 & 1.466 \\
\hline N10-C9 $\left(\mathrm{C}_{\mathrm{u}}\right)$ & $\ldots$ & $\ldots$ & $\ldots$ & 1.457 & 1.455 & 1.445 & 1.525 \\
\hline N10-C11 $\left(\mathrm{C}_{\mathrm{s}}\right)$ & $\ldots$ & $\ldots$ & $\ldots$ & 1.457 & 1.459 & 1.461 & 1.491 \\
\hline $\mathrm{N} 10-\mathrm{C} 12\left(\mathrm{C}_{\mathrm{c}}\right)$ & & & $\ldots$ & 1.453 & 1.458 & 1.455 & 1.586 \\
\hline
\end{tabular}

${ }^{\mathrm{a}}$ Atom labels refer to Fig. 13.

${ }^{\mathrm{b}} H(\mathrm{X}, 298)-H\left(\mathrm{X}-\mathrm{H}^{+}, 298\right)$. The proton affinities (PAs) of $\mathbf{1 7}$ are not given because it is an anion, and therefore its PAs are not appropriate for comparison to those found for neutrals.

Because 13 was nitrolyzed with $\mathrm{HNO}_{3}$ and acetic anhydride to produce 1,3-dinitroimidizolidine (Pagoria et al. 1996), the results for $\mathbf{1 3 - \mathbf { H } ^ { + }}$ represent a test of our hypothesis. (1,3dinitroimidizolidine has also been produced by nitrolyzing N,N'-diacetylimidazolidine with the nonacidic reagent nitronium tetrafluoroborate [Luk'yanov et al. 1976].) However, the bond that needs to break was found to be the shortest, at odds with what we expected. At the same time, the synthesis's yield was only $36 \%$. As such, the results could be rationalized, suggesting that beyond some (length) threshold (say $1.521 \AA$ ) all bonds that exceed it become equally likely to break. It would therefore be of interest to determine if $\mathbf{1 2}$ could be nitrolyzed to produce 1,3-dinitroimidizolidine. If not, it might give some credence to this possibility.

A comparison of results in Tables 6 and 7 shows that the $3 \mathrm{C}-\mathrm{N}\left(\mathrm{H}^{+}\right)$bonds of $\mathbf{1 2 s}-\mathbf{H}^{+}$and $\mathbf{1 2 e}-\mathbf{H}^{+}$

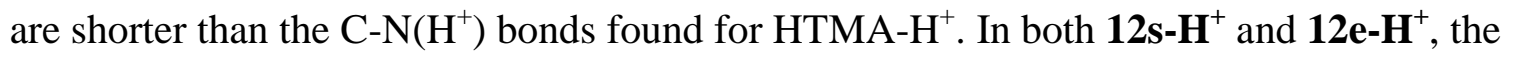
$\mathrm{C}_{\mathrm{c}}-\mathrm{N}\left(\mathrm{H}^{+}\right)$bond is slightly longer than the $\mathrm{C}_{\mathrm{u}}-\mathrm{N}\left(\mathrm{H}^{+}\right)$bond. If our hypothesis is correct, this result predicts that the nitrolysis of $\mathbf{1 2}$ will preferentially yield products with $>\mathrm{NCH}_{2} \mathrm{~N}<$ groups (such as 2,4-dinitro-2,4-diazapentane) rather than products with $>\mathrm{NCH}_{2} \mathrm{CH}_{2} \mathrm{~N}<$ groups (such as 2,5-dinitro-2,5-diazahexane). As such, an experimentally based investigation of this system would be of interest.

N-protonation of 14-16 also produced several results worth noting. For each molecule, 2 protonation scenarios were modeled. In one, the proton was attached to N2 on the convex side of the molecule. In the other, the proton was attached to N4 on the concave side of the molecule. Consistent with the expectation of Koppes et al. (1987), the basicity/proton affinity of $\mathbf{1 6}$ was found to be less than that of $\mathbf{1 4}$ or $\mathbf{1 5}$. 
Postulating that 15 was more sterically strained than $\mathbf{1 4}$, and that N-protonation would provide a low-energy path for ring opening and relief of this strain, Koppes et al. also hypothesized that the $\mathrm{C}_{\mathrm{c}}-\mathrm{N}\left(\mathrm{H}^{+}\right)$bond would break rather than the $\mathrm{C}_{\mathrm{u}}-\mathrm{N}\left(\mathrm{H}^{+}\right)$bond under acid nitrolysis conditions (see Fig. 8). Indicating that the $\mathrm{C}_{\mathrm{c}}-\mathrm{N}\left(\mathrm{H}^{+}\right)$bond is the longest, the modeling results are consistent with this expectation (and thus our hypothesis). In this context, the longer $\mathrm{C}_{\mathrm{s}}-\mathrm{N}\left(\mathrm{H}^{+}\right)$bond lengths found for $\mathbf{1 5}$ versus $\mathbf{1 4}$ are also consistent with the Koppes et al.'s expectation that $\mathbf{1 5}$ would be easier to nitrolyze than $\mathbf{1 4}$.

Despite the positive correlations between our hypothesis and expectations for $\mathbf{1 4}$ and $\mathbf{1 5}$, the results for $\mathbf{1 6}$ cast doubt on the proposed screening method's ability to predict a nitrolysis reaction's efficacy. In its case, when the proton was attached to $\mathrm{N} 2$, the longest $\mathrm{C}-\mathrm{N}\left(\mathrm{H}^{+}\right)$bond involved the acetyl C-atom $\left(\mathrm{C}_{\mathrm{s}}\right)$, and it was comparable in length to the $\mathrm{C}-\mathrm{N}\left(\mathrm{H}^{+}\right)$bonds in HMTA- $\mathrm{H}^{+}$. Moreover, the N2-protonated configuration was found to be approximately $8 \mathrm{kcal} / \mathrm{mol}$ lower in energy than the N4-protonated configuration. In the absence of other data, this result coupled with our hypothesis would lead us to predict that $\mathbf{1 6}$ has the potential to be a precursor for the synthesis of 18. The fact that Koppes et al. were unsuccessful in producing 18 from 16 does not necessarily mean that it cannot be done. But it is clear that seemingly favorable modeled $\mathrm{C}-\mathrm{N}\left(\mathrm{H}^{+}\right)$bonds lengths are no guarantee that a proposed synthesis approach will work.

Subsequent to Koppes et al.’s study, 18 was synthesized by Gilardi et al. (2002) ("with the use of powerful and quite dangerous new nitrolysis agents”) and by Sysolatin et al. (2006). The approach employed by Sysolatin et al. is particularly intriguing. It involves nitrating a precursor (17) produced by condensing $\mathrm{H}_{2} \mathrm{NSO}_{3} \mathrm{M}$ with glyoxal and formaldehyde. $\mathrm{H}_{2} \mathrm{NSO}_{3} \mathrm{M}$ has also been employed to produce a precursor for CL-20, and we could envision it being employed to produce precursors for some of the notional PCNAs considered in this report.

Predicted bond lengths for the (N-protonated) conjugate acid of $19\left(\mathbf{1 9 - \mathbf { H } ^ { + }}\right)$ are given in Table 9. For all 4 protonation sites, the $\mathrm{C}_{\mathrm{c}}-\mathrm{N}\left(\mathrm{H}^{+}\right)$bond is the longest.

Predicted bond lengths for the (N-protonated) conjugate acids of the cucurbitaminals are given in Table 10. This table also lists the (gas-phase) proton affinities that were computed for the bases. The proton affinities of the cage structures tend to be higher than those of the noncage structures. This was expected on the basis of the extra strain in the cage structures and, therefore, the extra strain relief provided by N-protonation. 
Table 10 Predicted bond lengths ${ }^{\mathrm{a}}$ ( $r_{e}$ in angstroms) for N-protonated cucurbitaminals and $\mathbf{3 1}$ and proton affinities ${ }^{\mathrm{b}}$ (in kilocalories per mole) for their conjugate bases

\begin{tabular}{|c|c|c|c|c|c|c|c|c|c|c|c|}
\hline Parameter & \multicolumn{2}{|c|}{ CB[5]A-H ${ }^{+}$} & \multicolumn{2}{|c|}{$\mathrm{CB}[6] \mathrm{A}-\mathrm{H}^{+}$} & \multicolumn{2}{|c|}{$\mathbf{C B}[7] \mathbf{A}-\mathbf{H}^{+}$} & \multicolumn{2}{|c|}{ CB[8]A-H ${ }^{+}$} & \multicolumn{2}{|c|}{ CB[10]A-H ${ }^{+}$} & $31-\mathbf{H}^{+}$ \\
\hline Proton site & N2 & N4 & N2 & N4 & N2 & N4 & N2 & N4 & N2 & N4 & \\
\hline Proton affinity & 243 & 242 & 244 & 242 & 246 & 242 & 247 & 242 & 250 & 241 & 220 \\
\hline N2-C1 $\left(\mathrm{C}_{\mathrm{b}}\right)$ & 1.576 & 1.473 & 1.564 & 1.470 & 1.561 & 1.469 & 1.556 & 1.470 & 1.544 & 1.472 & $1.538^{\mathrm{d}}$ \\
\hline N2-C3 $\left(C_{u}\right)$ & 1.498 & 1.424 & 1.500 & 1.425 & 1.501 & 1.423 & 1.502 & 1.423 & 1.503 & 1.423 & $\cdots$ \\
\hline $\mathrm{N} 2-\mathrm{C} 7\left(\mathrm{C}_{\mathrm{c}}\right)$ & 1.579 & 1.469 & 1.595 & 1.466 & 1.609 & 1.466 & 1.620 & 1.466 & 1.637 & 1.469 & $\ldots$ \\
\hline N4-C3 $\left(C_{u}\right)$ & 1.452 & 1.507 & 1.447 & 1.510 & 1.445 & 1.514 & 1.444 & 1.516 & 1.443 & 1.519 & . . \\
\hline N4-C5 $\left(C_{b}\right)$ & 1.483 & 1.570 & 1.482 & 1.562 & 1.480 & 1.560 & 1.477 & 1.557 & 1.474 & 1.556 & $\because$ \\
\hline N4-C6 $\left(\mathrm{C}_{c}\right)$ & 1.458 & 1.583 & 1.463 & 1.586 & 1.463 & 1.583 & 1.462 & 1.586 & 1.460 & 1.583 & \\
\hline
\end{tabular}

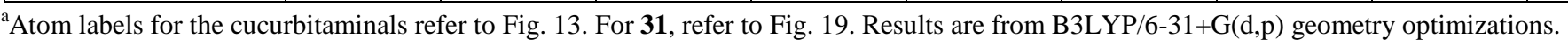

${ }^{\mathrm{b}} H(\mathrm{X})-H\left(\mathrm{X}-\mathrm{H}^{+}\right)$. For the cucurbitaminals, the estimates are derived from B3LYP/6-31+G(d,p) electronic energies and ZPVEs derived from B3LYP/6-31G(d) results. For 31, both the electronic energy and the ZPVE were derived from B3LYP/6-31G(d) results.

${ }^{c}$ All $\mathrm{N}$-atoms in $\mathbf{3 1}$ are effectively the same.

${ }^{\mathrm{d}}$ The lengths of the $3 \mathrm{C}-\mathrm{N}\left(\mathrm{H}^{+}\right)$bonds are the same. 
For the cucurbitaminals, the hope that the $\mathrm{C}_{\mathrm{u}}-\mathrm{N}\left(\mathrm{H}^{+}\right)$bonds would be longer than the other 2 $\mathrm{C}-\mathrm{N}\left(\mathrm{H}^{+}\right)$bond types was not observed. Rather, as found for 16, they were the shortest in all cases. As such, the results recommend against an attempt to implement Scheme I. The lengths of the $\mathrm{C}_{\mathrm{b}}-\mathrm{N}\left(\mathrm{H}^{+}\right)$and $\mathrm{C}_{\mathrm{c}}-\mathrm{N}\left(\mathrm{H}^{+}\right)$bonds suggest that there might be a slight preference for breaking $\mathrm{C}_{\mathrm{c}}-\mathrm{N}$ bonds. Therefore, an attempt to implement Scheme III might work. However, as evidence that could be employed to justify such an undertaking, we consider the results far from compelling.

\subsection{Targeted PCNAs}

Although the results presented in the previous section suggested that the schemes proposed for producing the targeted PCNAs will be at best non-regioselective, and therefore low-yielding, structures for the targets were built and optimized. It was found that despite considerable effort to construct highly symmetric structures with 8-membered (substructural) rings configured to resemble $\beta$-HMX and/or $\delta$-HMX, most starting geometries “collapsed” to irregular/amorphous structures in the course of the optimization procedure. The 2 most symmetric structures that were produced (20 and 21) are shown in Fig. 14. Various parameters are reported for them in Table 11. In the figure, the program that produced the representations did not draw bonds between a number of proximate $\mathrm{CH}$ groups. This happened because the distance between the $\mathrm{C}$-atoms exceeds the 1.630 - $\AA$ threshold the program employs to identify C-C (single) bonds. (Nominal values for such bonds are approximately $1.540 \AA$.) As such, the results are considered a strong indication that the structures will be unstable. Therefore, the investigation of Schemes I and II and their targets was stopped. 


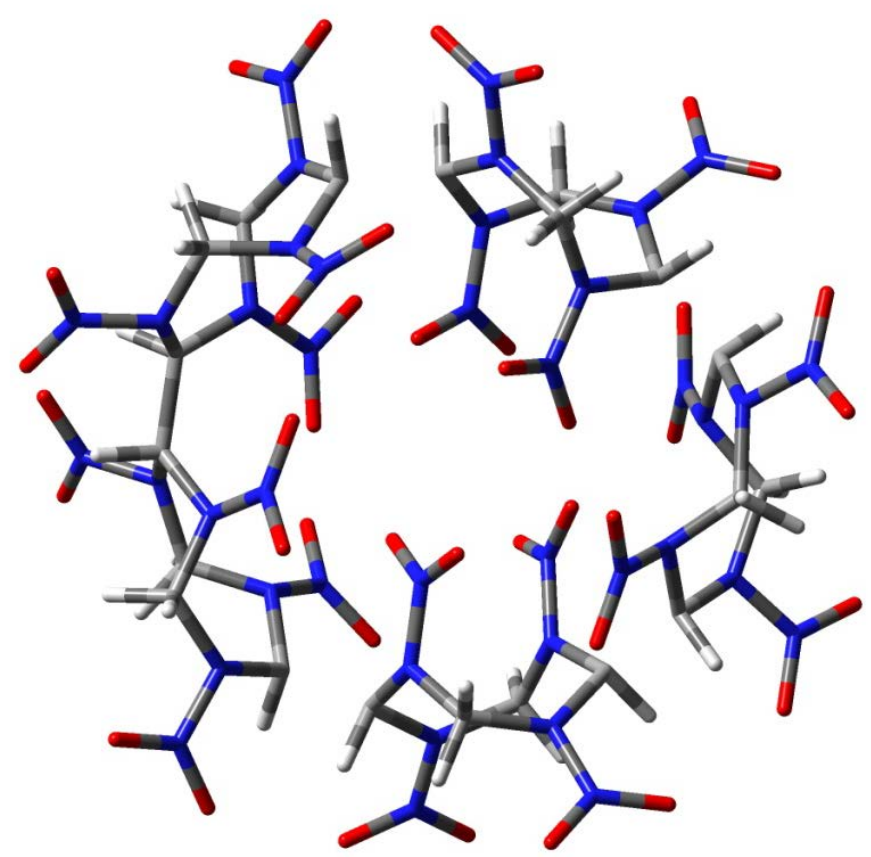

20

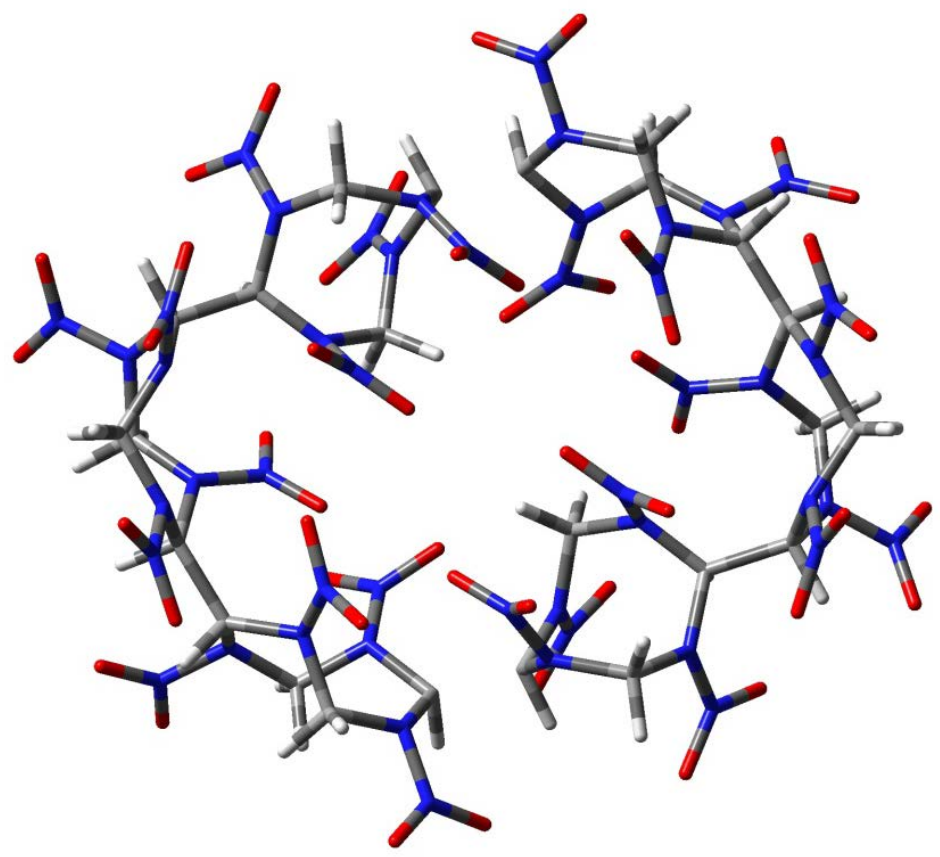

21

Fig. 14 Molecular structures for targets of the nitrolysis of $\mathrm{CB}[5] \mathrm{A}(\mathbf{2 0})$ and $\mathrm{CB}[6] \mathrm{A}(\mathbf{2 1})$ 
Table 11 Property predictions for PCNA targets of Schemes I and II: $\mathbf{2 0}$ and $\mathbf{2 1}^{\mathrm{a}}$

\begin{tabular}{|l|c|c|c|}
\hline \multicolumn{1}{|c|}{ Parameter } & Units & 20 & 21 \\
\hline$r_{e}(\mathrm{~N}-\mathrm{CH})^{\mathrm{b}}$ & $\AA$ & 1.504 & 1.509 \\
\hline$r_{e}\left(\mathrm{~N}-\mathrm{CH}_{2}\right)^{\mathrm{b}}$ & $\AA$ & 1.515 & 1.513 \\
\hline$r_{e}(\mathrm{C}-\mathrm{C})^{\mathrm{b}}$ & $\AA$ & 1.647 & 1.644 \\
\hline$r_{e}\left(\mathrm{~N}-N O_{2}\right)^{\mathrm{b}}$ & $\AA$ & 1.422 & 1.452 \\
\hline \multicolumn{3}{|l|}{} \\
\hline$\Delta_{f} \mathrm{H}_{g}(298)$ & $\mathrm{kcal} / \mathrm{mol}$ & 471 & 513 \\
\hline
\end{tabular}

${ }^{a}$ Attempts to calculate N-N BDEs and densities for these molecules proved to be computationally impractical.

${ }^{\mathrm{b}} \mathrm{B} 3 \mathrm{LYP} / 6-31 \mathrm{G}(\mathrm{d})$ results. The longest bond found for the given type is reported.

\subsection{Other Notional PCNAs}

\subsubsection{Trans-bicyclo-HMX (22)}

Prior to its synthesis, bicyclo-HMX (18) was a much-sought target because its density was expected to be higher than HMX's. However, it proved to be lower: $1.86 \mathrm{~g} / \mathrm{cm}^{3}$ (Gilardi et al. 2002) versus $1.90 \mathrm{~g} / \mathrm{cc}$ (Deschamps et al. 2011). This result is assumed to be due to inefficient packing caused by the asymmetry of the thermodynamically preferred gauche molecular structure. The gauche structure also effectively prevents the (outer) ring from acquiring a configuration similar to the lowest energy and least sensitive $(\beta)$ form of HMX. Therefore, we were curious about how the properties of a trans configuration that resembled $\beta$-HMX would compare. Labeled 22, the molecular structure of the lowest energy conformer that was found is shown in Fig. 15.

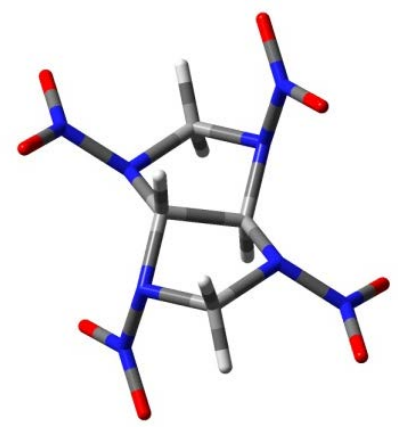

Fig. 15 The molecular structure of 22

Results for $\beta$-HMX, 18 and 22 are compared in Table 12. Somewhat surprisingly, the density estimate produced for $\mathbf{2 2}$ is lower than the one produced for $\mathbf{1 8}$. However, the density estimate for $\beta$-HMX is even lower, indicative of the limits of the estimation method's reliability. Based on the result for $\beta$-HMX and comparisons between other estimates and measured values that are presented in this report, the density estimates produced by the method employed for this study appear to be reliable to within $\pm 5 \%$. On this basis, 22's density could conceivably be as high as $1.93 \mathrm{~g} / \mathrm{cm}^{3}$. However, the similarity between 18 and 22, coupled with the good agreement observed between the density estimate for $\mathbf{1 8}$ and a measured value, suggests that 22's density will be close to $1.84 \mathrm{~g} / \mathrm{cm}^{3}$. 
Table 12 Property predictions for $\beta$-HMX, 18, and 22

\begin{tabular}{|l|c|c|c|c|}
\hline \multicolumn{1}{|c|}{ Parameter } & Units & $\boldsymbol{\beta}$-HMX & $\mathbf{1 8}$ & $\mathbf{2 2}$ \\
\hline$r_{e}(\mathrm{~N}-\mathrm{CH})^{\mathrm{a}}$ & $\AA$ & & 1.470 & 1.480 \\
\hline$r_{e}\left(\mathrm{~N}-\mathrm{CH}_{2}\right)^{\mathrm{a}}$ & $\AA$ & 1.479 & 1.472 & 1.514 \\
\hline$r_{e}(\mathrm{C}-\mathrm{C})^{\mathrm{a}}$ & $\AA$ & & 1.566 & 1.529 \\
\hline$\left.r_{e}\left(\mathrm{~N}^{-N^{2}}\right)^{\mathrm{a}}\right)^{\mathrm{a}}$ & $\AA$ & 1.396 & 1.435 & 1.436 \\
\hline & $\ldots$ & $\ldots$ & $\ldots$ & $\ldots$ \\
\hline$B D E(N-N)^{\mathrm{b}}$ & $\mathrm{kcal} / \mathrm{mol}$ & 43 & 40 & 33 \\
\hline$\Delta_{f} H_{g}(298)$ & $\mathrm{kcal} / \mathrm{mol}$ & 55 & 69 & 93 \\
\hline$\Delta H_{s}$ & $\mathrm{kcal} / \mathrm{mol}$ & 33 & 31 & 30 \\
\hline$\rho$ (measured) & $\mathrm{g} / \mathrm{cm}^{3}$ & $1.904^{\mathrm{c}}$ & $1.86^{\mathrm{d}}$ & $\ldots$ \\
\hline$\rho$ (estimate) & $\mathrm{g} / \mathrm{cm}^{3}$ & 1.811 & 1.853 & 1.839 \\
\hline
\end{tabular}

${ }^{\mathrm{a}} \mathrm{B} 3 \mathrm{LYP} / 6-31 \mathrm{G}(\mathrm{d})$ results. The longest bond found for the given type is reported.

${ }^{\mathrm{b}}$ The smallest BDE found is reported.

${ }^{\mathrm{c}}$ Deschamps et al. (2011).

${ }^{\mathrm{d}}$ Gilardi et al. (2002).

The lengths of corresponding C-N and C-C bonds in 18 and 22 are observed to be significantly different, but trade-offs are involved, and it would be highly speculative to predict the stability of 22 on the basis of these comparisons. On the other hand, 22 was predicted to be approximately $27 \mathrm{kcal} / \mathrm{mol}$ higher in energy than 18, and one of the N-N BDEs was found to be only 33 $\mathrm{kcal} / \mathrm{mol}$. Therefore, even if it could be made, it seems likely that it would be unstable. Taken together, the results indicate that $\mathbf{2 2}$ is not a promising target.

\subsubsection{2,6,7-Trinitro-2,6,7-triaza[2.2.2]octane (23)}

As mentioned in the introduction, a number of notional PCNAs with tris(nitramino)methane fragments have been proposed and studied via computationally based methods (notably 1-3), but the only compound with a tris(nitramino)methane fragment that appears to have been isolated is 2,4,10-trinitro-2,4,10-triazaadamantane (4) (Nielsen et al. 1998). Considering variations of the route (presented in Fig. 3) that might produce other compounds with a tris(nitramino)methane fragment, we postulated one involving tris(nitraminomethyl)methane and 2,6,7-trinitro-2,6,7triaza[2.2.2] octane (23) (Fig. 16). The synthesis of tris(nitraminomethyl)methane has not been reported in the open literature, but 1,3-diamino-2-aminomethylpropane has (Geissman et al. 1946), and commercial sources appear to be available. In addition, 2,6,7-triazabicyclo[2.2.2]octane-3,5,8-triones have been synthesized via reactions involving pyrimidiniumolates (Gotthardt and Blum 1986). Thus, some alternate routes to 23 could be imagined. 


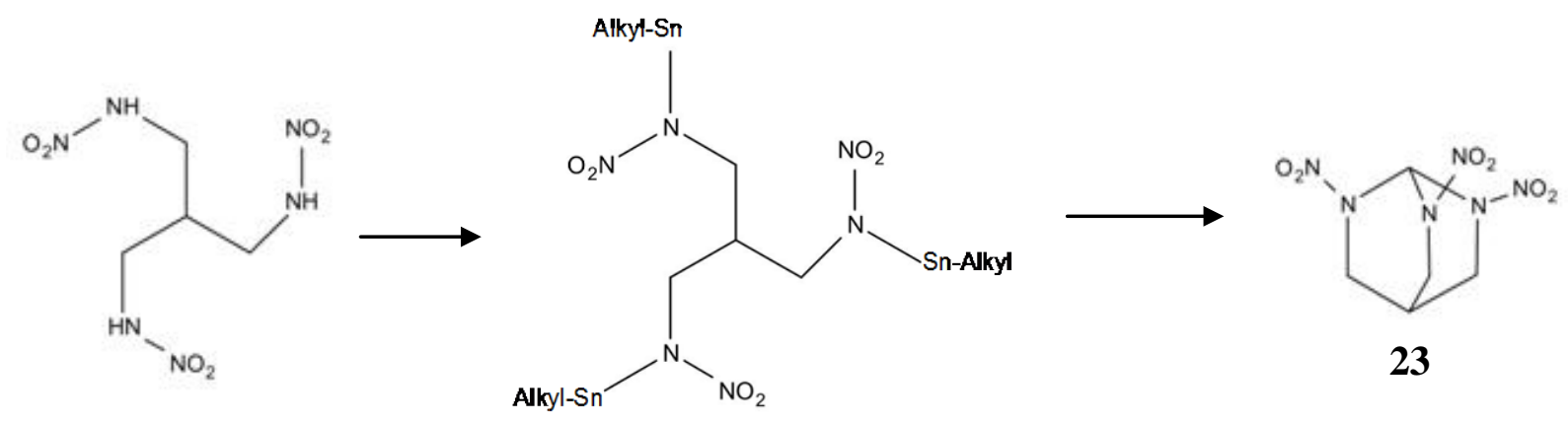

Fig. 16 Scheme envisioned for the synthesis of $\mathbf{2 3}$

The molecular structures of $\mathbf{4}$ and $\mathbf{2 3}$ are shown in Fig. 17. Selected bond lengths and other property predictions for the pair are provided in Table 13. (Results produced for $\mathbf{1 - 3}$ are also provided in the table.) The comparison suggests that $\mathbf{2 3}$ will be more stable than $\mathbf{4}$. However, the density estimate produced for $\mathbf{2 3}$ is not impressive $\left(1.738 \mathrm{~g} / \mathrm{cm}^{3}\right)$, and $\Phi$ for the system is 2.67 . Therefore, it is not expected to be a replacement for RDX or HMX. Nevertheless, its synthesis and characterization would surely shed light on the nature of the tris(nitramino)methane fragment and the potential for synthesizing other candidates with this fragment. Thus, an attempt to synthesize it would appear to be warranted.

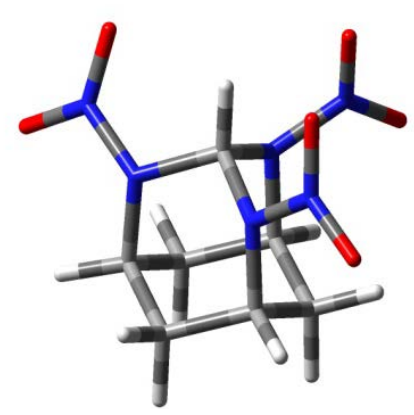

4

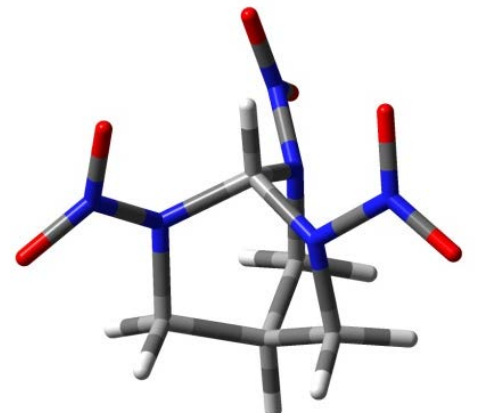

23

Fig. 17 The molecular structures of $\mathbf{4}$ and $\mathbf{2 3}$ 
Table 13 Property predictions for $\mathbf{1 - 4}$ and $\mathbf{2 3}$

\begin{tabular}{|l|c|c|c|c|c|c|}
\hline \multicolumn{1}{|c|}{ Parameter } & Units & $\mathbf{1}$ & $\mathbf{2}$ & $\mathbf{3}$ & $\mathbf{4}$ & $\mathbf{2 3}$ \\
\hline$r_{e}(\mathrm{~N}-\mathrm{CH})^{\mathrm{a}}$ & $\AA$ & 1.480 & 1.467 & 1.456 & $1.467^{\mathrm{b}}$ & 1.461 \\
\hline$r_{e}\left(\mathrm{~N}-\mathrm{CH}_{2}\right)^{\mathrm{a}}$ & $\AA$ & $\ldots$ & $\ldots$ & $\ldots$ & $1.488^{\mathrm{c}}$ & 1.479 \\
\hline$r_{e}\left(\mathrm{~N}-\mathrm{NO}_{2}\right)^{\mathrm{a}}$ & $\AA$ & 1.438 & 1.467 & 1.435 & 1.409 & 1.396 \\
\hline \multicolumn{6}{|l|}{} \\
\hline$B D E(\mathrm{~N}-\mathrm{N})$ & $\mathrm{kcal} / \mathrm{mol}$ & 40 & 36 & 40 & 44 & 44 \\
\hline$\Delta H_{g}(298)$ & $\mathrm{kcal} / \mathrm{mol}$ & 128 & 202 & 273 & 27 & 37 \\
\hline$\Delta H_{s}$ & $\mathrm{kcal} / \mathrm{mol}$ & 39 & 69 & 94 & 37 & 30 \\
\hline$\rho{\text { (estimate })^{\mathrm{d}}}^{\mathrm{g}}$ & $\mathrm{g} / \mathrm{cm}^{3}$ & 2.009 & 2.068 & 2.087 & 1.717 & 1.738 \\
\hline$\rho$ (estimate) & $\mathrm{g} / \mathrm{cm}^{3}$ & $1.947^{\mathrm{e}}$ & $2.009^{\mathrm{f}}$ & $2.518^{\mathrm{g}}$ & $\ldots$ & $\ldots$ \\
\hline
\end{tabular}

${ }^{\mathrm{a}} \mathrm{B} 3 \mathrm{LYP} / 6-31 \mathrm{G}(\mathrm{d})$ results. The longest bond of this type is reported.

${ }^{\mathrm{b}}$ For NC(N)N fragment.

${ }^{\mathrm{c}}$ For $\mathrm{NC}(\mathrm{C}) \mathrm{C}$ fragment.

${ }^{\mathrm{d}}$ This work.

${ }^{\text {e}}$ Dzyabchenko et al. (1996).

fZhang et al. (2012).

g Ju and Wang (2009).

\subsubsection{Notional PCNAs With Just $>\mathrm{C}(\mathrm{H}) \mathrm{C}(\mathrm{H})<$ and $>\mathrm{N}^{-\mathrm{NO}_{2}}$ Groups}

Having $2>\mathrm{NNO}_{2}$ groups for every $>\mathrm{C}(\mathrm{H}) \mathrm{C}(\mathrm{H})<$ group, this class of compounds has stoichiometries with the general form $\mathrm{C}_{\mathrm{x}} \mathrm{H}_{\mathrm{x}} \mathrm{N}_{2 \mathrm{x}} \mathrm{O}_{2 \mathrm{x}}(\mathrm{x} \geq 4)$. CL-20 $\left(\mathrm{C}_{6} \mathrm{H}_{6} \mathrm{~N}_{12} \mathrm{O}_{12}\right)$ belongs to this class. All have $\Phi=1.25$. Because they have just $>\mathrm{NNO}_{2}$ and $>\mathrm{C}(\mathrm{H}) \mathrm{C}(\mathrm{H})<$ groups, precursors could (in principle) be formed in a single step from the condensation of $\mathrm{H}_{2} \mathrm{NSO}_{4} \mathrm{M}$ and glyoxal. (No such result has been reported.) Molecular structures for this class of compounds are given in Fig. 18, and property predictions are presented in Table 14. (Again, molecules with adjacent $>\mathrm{NNO}_{2}$ groups were not modeled.) 

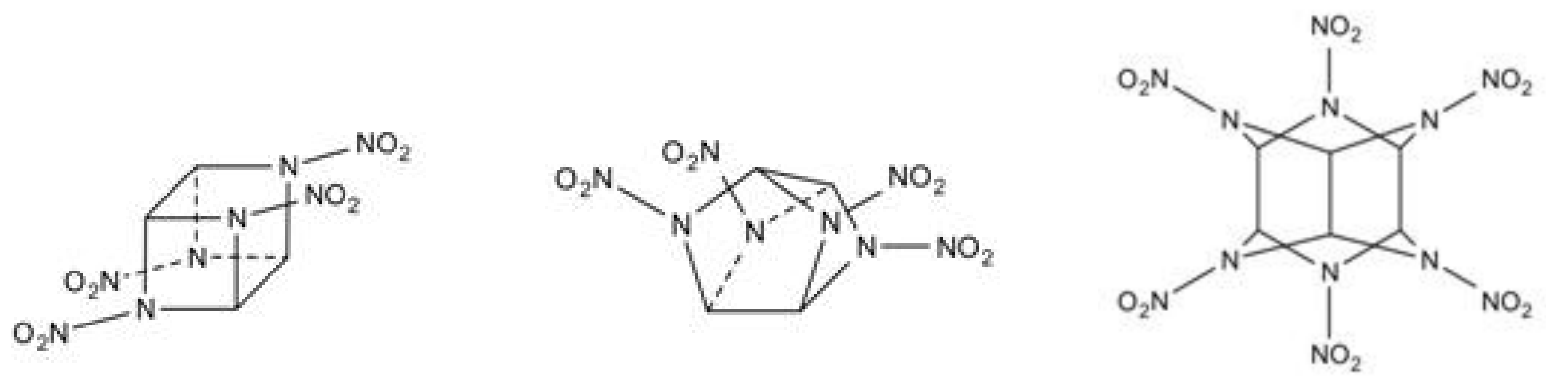

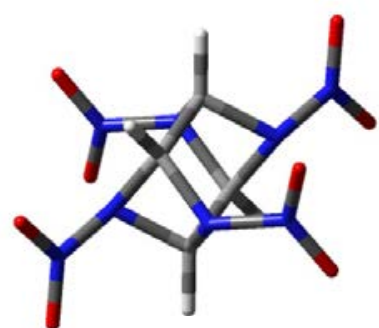

24

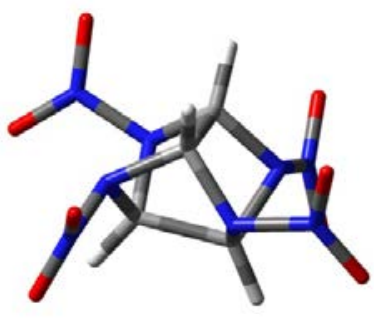

25

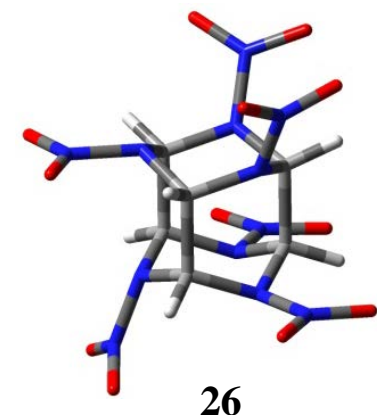

26
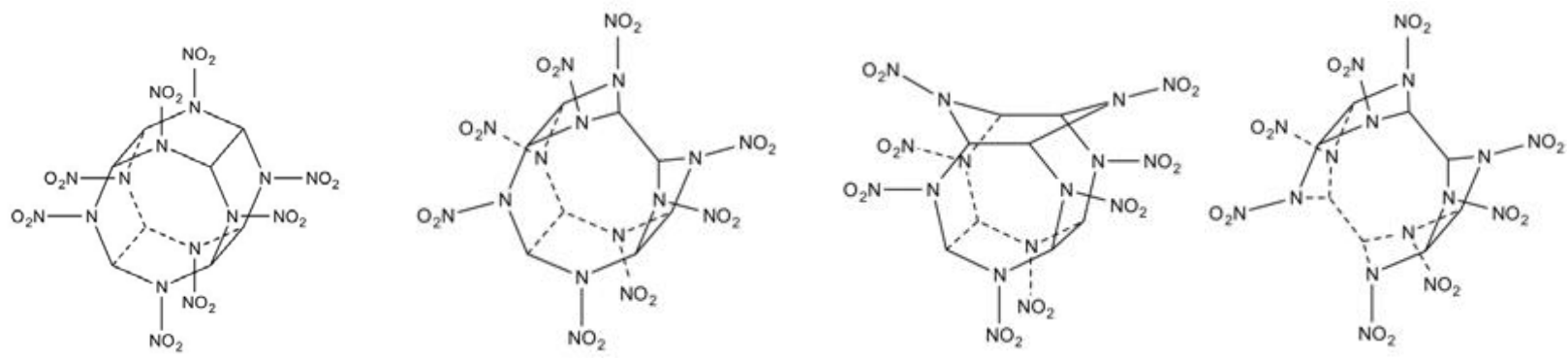

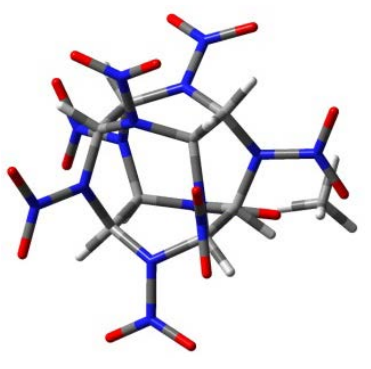

27

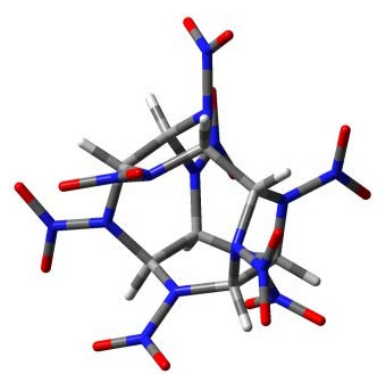

28

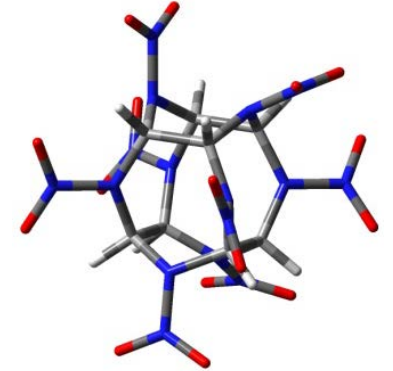

29

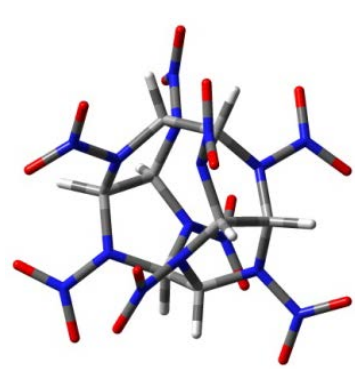

30

Fig. 18 Molecular structures of notional PCNAs with just $>\mathrm{CHCH}<$ and $>\mathrm{NNO}_{2}$ groups: 24-30 
Table 14 Property predictions for PCNAs with just $>\mathrm{CHCH}<$ and $>\mathrm{NNO}_{2}$ groups

\begin{tabular}{|c|c|c|c|c|c|c|c|c|c|}
\hline Parameter & Units & 24 & 25 & $\varepsilon$-CL20 & 26 & 27 & 28 & 29 & 30 \\
\hline$r_{e}(\mathrm{~N}-\mathrm{CH})^{\mathrm{a}}$ & $\AA$ & 1.495 & 1.492 & 1.475 & 1.471 & 1.457 & 1.475 & 1.463 & 1.471 \\
\hline$r_{e}(\mathrm{C}-\mathrm{C})^{\mathrm{a}}$ & $\AA$ & 1.603 & 1.631 & 1.603 & 1.600 & 1.574 & 1.570 & 1.597 & 1.574 \\
\hline$r_{e}\left(\mathrm{~N}-\mathrm{NO}_{2}\right)^{\mathrm{a}}$ & $\AA$ & 1.444 & 1.428 & 1.437 & 1.440 & 1.431 & 1.444 & 1.446 & 1.432 \\
\hline$H(298) / \mathrm{N}(\mathrm{C}-\mathrm{C})$ & hartrees & -596.9524 & -596.9802 & -597.0055 & -597.0069 & -597.0041 & -597.0046 & -596.9986 & -597.0077 \\
\hline$\Delta H(298) / \mathrm{N}(\mathrm{C}-\mathrm{C})^{\mathrm{b}}$ & $\mathrm{kcal} / \mathrm{mol}$ & 33.3 & 15.9 & 0.0 & -0.9 & 0.9 & 0.6 & 4.3 & -1.4 \\
\hline$B D E(\mathrm{~N}-\mathrm{N})$ & $\mathrm{kcal} / \mathrm{mol}$ & 39 & 43 & 40 & 42 & 41 & 38 & 43 & 39 \\
\hline$\Delta H_{q}(298)$ & $\mathrm{kcal} / \mathrm{mol}$ & 147 & 109 & 126 & 121 & 164 & 165 & 178 & 158 \\
\hline$\Delta H_{s}$ & $\mathrm{kcal} / \mathrm{mol}$ & 29 & 28 & 45 & 45 & 67 & 68 & 67 & 68 \\
\hline$\rho$ (measured) & $\mathrm{g} / \mathrm{cm}^{3}$ & $\ldots$ & $\ldots$ & $2.044^{\mathrm{C}}$ & $\ldots$ & $\ldots$ & $\ldots$ & $\ldots$ & 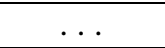 \\
\hline 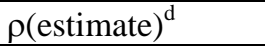 & $\mathrm{g} / \mathrm{cm}^{3}$ & 1.904 & 1.912 & 1.991 & 1.984 & 2.014 & 2.007 & 2.019 & 1.993 \\
\hline$\rho$ (estimate) & $\mathrm{g} / \mathrm{cm}^{3}$ & $\ldots$ & $\ldots$ & $1.982^{\mathrm{e}}$ & $1.891^{\mathrm{e}}$ & $2.021^{\mathrm{f}}$ & $\ldots$ & $\ldots$ & $\ldots$ \\
\hline
\end{tabular}

${ }^{a} B 3 L Y P / 6-31+G(d, p)$ results. The longest bond of the given class is reported.

bompared to CL-20.

${ }^{\mathrm{c}}$ Nielsen et al. (1998).

$\stackrel{\text { w }}{A}$ This work.

e Dzyabchenko et al. (1996).

f Zhao and Lu (2013). 
The smallest cages of this class have $2>\mathrm{C}(\mathrm{H}) \mathrm{C}(\mathrm{H})<$ groups and $4>\mathrm{NNO}_{2}$ groups $\left(\mathrm{C}_{4} \mathrm{H}_{4} \mathrm{~N}_{8} \mathrm{O}_{8}\right)$. In one (3,6,7,8-tetranitro-3,6,7,8-tetraazatricyclo[3.1.1.1 ${ }^{2,4}$ ]octane, 24), the $2 \mathrm{C}$-C bonds are parallel to one another. In the other (25), the $\mathrm{C}$ - $\mathrm{C}$ bonds are perpendicular to one another. For each isomer, 3 different equilibrium conformers were modeled. The lowest energy configurations that were found are shown in Fig. 18. The lowest energy configuration found for 25 was predicted to be more than $36 \mathrm{kcal} / \mathrm{mol}$ lower in energy than the lowest energy configuration found for $\mathbf{2 4}$. Given that $\mathbf{2 5}$ has only 5-membered rings and $\mathbf{2 4}$ has two 4-membered rings, this result could perhaps have been anticipated.

Based on a SciFinder search, no studies of $\mathbf{2 4}$ or $\mathbf{2 5}$ have been published. This finding is not that surprising. Compared to CL-20, 24 (25) has $34 \mathrm{kcal} / \mathrm{mol}$ (16 kcal/mol) more energy per C-C group $[H(298) / \mathrm{N}(\mathrm{C}-\mathrm{C})]$, and this difference is reflected in the lengths of the longest $\mathrm{C}-\mathrm{N}$ and $\mathrm{C}-\mathrm{C}$ bonds found for them (see Table 14). Thus, it is considered unlikely that either $\mathbf{2 4}$ or $\mathbf{2 5}$ are stable. As for potential precursors, no studies of molecules with the cage structure of $\mathbf{2 5}$ were found. Interested in the discovery of proton sponges, Estrada and Simon-Manso (2006) conducted a computationally based study of 3,6,7,8-tetraazatricyclo[3.1.1.1 ${ }^{2,4}$ ]octane, which has 24's cage structure. No evidence that 3,6,7,8-tetraazatricyclo[3.1.1.1 $1^{2,4}$ ]octane has been isolated could be found.

The next largest members of this class have $3>\mathrm{C}(\mathrm{H}) \mathrm{C}(\mathrm{H})<$ groups and $6>\mathrm{NNO}_{2}$ groups $\left(\mathrm{C}_{6} \mathrm{H}_{6} \mathrm{~N}_{12} \mathrm{O}_{12}\right)$. Four different isomers can be built with the set. One of them is CL-20. (Results for the $\varepsilon$ polymorph are presented here.) Two of the remaining three have 4-membered rings. As such, they were expected to be much higher in energy than CL-20 and therefore have little likelihood of being synthesized or stable. Thus, they were not modeled. The fourth (26) is shown in Fig. 18.

A distinguishing difference between the structures of $\mathbf{2 6}$ and CL-20 is the orientations that their 3 $\mathrm{C}-\mathrm{C}$ bonds have with respect to one another. In 26, all $3 \mathrm{C}-\mathrm{C}$ bonds are parallel to one another. In CL-20, 2 C-C bonds are parallel to one another and the third is perpendicular to them. Pivina and coworkers have previously made predictions for $\mathbf{2 6}$ on the basis of computationally based methods (Dzyabchenko et al. 1996, Pivina et al. 1995). The 1995 study and this one find 26 to be lower in energy than CL-20. In addition, for the 3 bond types in CL-20 and 26, the differences between the lengths of the longest bond of each type in each molecule are negligible (see Table 14).

In the absence of other data, we would have expected 26's synthesis to be no more difficult than CL-20's, and that its stability would not be an issue. However, no report of 26's synthesis could be found. (Nielsen et al. [1998] discuss an unsuccessful attempt that they made.) As such, the findings indicate that comparisons of modeled bond lengths and relative energies are not (by themselves) predictive of the ease with which a PCNA can be synthesized. Their value lies mainly in identifying candidates that have little to no chance of being isolated. 
The final members of the class that were investigated have $4>\mathrm{C}(\mathrm{H}) \mathrm{C}(\mathrm{H})<$ groups and $8>\mathrm{N}-\mathrm{NO}_{2}$ groups $\left(\mathrm{C}_{8} \mathrm{H}_{8} \mathrm{~N}_{16} \mathrm{O}_{16}\right)$. Excluding geometries with 4-membered (sub)rings, there are 4 isomers that can be postulated:

- $\quad$ One in which all the C-C bonds are parallel to one another (27)

- One in which 3 of the C-C bonds are parallel to one another and the fourth is perpendicular to them (28)

- $\quad$ One in which 2 of the $\mathrm{C}-\mathrm{C}$ bonds are parallel to one another, the other 2 are perpendicular to the first 2, and they are on the same side of the plane containing the first 2 (29)

- $\quad$ One in which 2 of the C-C bonds are parallel to one another and the other 2 are perpendicular to them, but the second 2 are on opposite sides of the plane containing the first 2 (30)

Previous studies of 28-30 could not be found. (Indeed, no study of any molecule with their cage structure could be found.) A computationally based study of $\mathbf{2 7}$ was published by Zhao and Lu (2013). It was the only one found in which a molecule with 27's cage structure was characterized. One of that study's conclusions was that dissociation of an $\mathrm{N}-\mathrm{NO}_{2}$ bond would likely be the first step in its thermal decomposition, and based on the dissociation energy that was calculated for the step ( $37 \mathrm{kcal} / \mathrm{mol}$ ), it was predicted that the compound would be stable enough to be employed as an explosive. The smallest BDE value we calculated was even higher (41 kcal/mol), but again, given the limitations of BDEs with respect to predicting stability, we do not consider the result an indication that $\mathbf{2 7}$ has an even higher probability of being stable than previously thought.

Two conformers of $\mathbf{2 7}$ were modeled in this study. In both, the $2 \mathrm{HMX}$ substructures had orientations similar to $\delta$-HMX, with the less symmetric variation (shown) being $1.6 \mathrm{kcal} / \mathrm{mol}$ lower in energy. Its $H(298) / \mathrm{N}(\mathrm{C}-\mathrm{C})$ is $0.4 \mathrm{kcal} / \mathrm{mol}$ higher than that of $\varepsilon$-CL-20, indicating it is slightly more strained. However, for the 3 bond types found in this class of molecules, the longest bond found for each type in $\mathbf{2 7}$ is shorter than the longest bond of the corresponding type in CL-20. As such, we consider it surprising that 27's synthesis has not been reported.

As for 28-30, the relative enthalpies of these molecules (and 27) were found to be $H(30)<H(28)<H(27)<H(29)$. Given that 30 has the smallest rings of the 4, its $H(298)$ value relative to the values of the other 3 is somewhat surprising. Indeed, compared to CL-20, its $H(298) / \mathrm{N}(\mathrm{CHCH})$ estimate is $1.8 \mathrm{kcal} / \mathrm{mol}$ lower, and its longest bond lengths are similar. Thus, it seems possible that it will be at least as stable CL-20.

Beyond favorable comparisons with CL-20, 30 became a focus of the study when a highly symmetric aminal (31) was identified as having qualities that could make it a precursor. Shown in Fig. 19, it is a dodecahedron composed exclusively of 5-sided facets. Computationally based studies of 31 have been previously published (Alder et al. 2001, Alkorta et al. 1991). No reports of its synthesis were found. Based on results from the B3LYP/6-31+G(d,p) model, its proton 
affinity was predicted to be $222 \mathrm{kcal} / \mathrm{mol}$. This value is slightly less than the one computed for HTMA. As expected on the basis of the symmetry of the molecule, the $3 \mathrm{C}-\mathrm{N}\left(\mathrm{H}^{+}\right)$bonds of its conjugate acid have the same length. They are somewhat shorter than those of the corresponding bonds in HTMA-H ${ }^{+}: 1.538 \AA$ versus 1.557 A. Recalling the Bachmann process, $\mathbf{3 0}$ and $\mathbf{3 1}$ are considered intriguing targets.
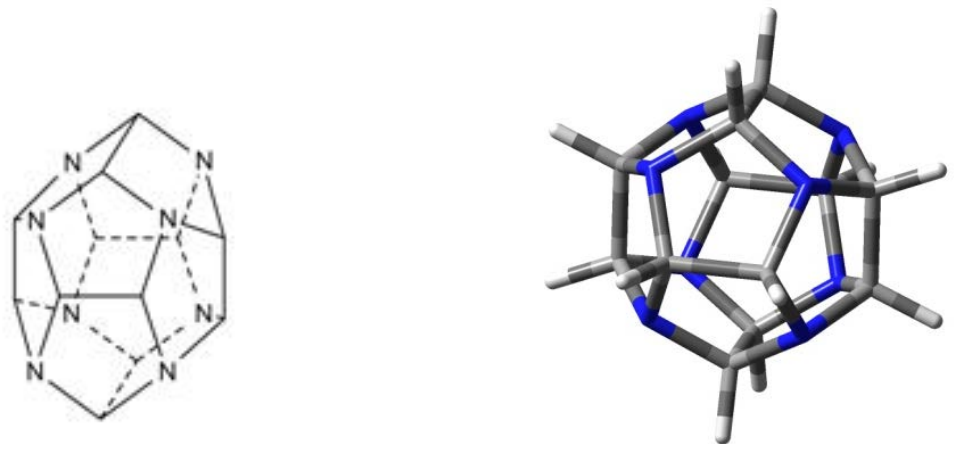

Fig. 19 The molecular structure of $\mathbf{3 1}$

Molecular designs for nitrolysis precursors for 27, 28, and 29 were also postulated and their geometries modeled. But none had the simplicity/symmetry of 31. Therefore, they were considered to have no chance of being made in one step. In addition, on the basis of the lengths of the bonds produced by N-protonation, the bonds that would be broken in these designs would not be those that would lead to the target. Therefore, results for these molecules are not presented.

\subsubsection{PCNAs with Just $>\mathrm{C}(\mathrm{H}) \mathrm{C}(\mathrm{H})<,>\mathrm{CH}_{2}$, and $>\mathrm{N}-\mathrm{NO}_{2}$ Groups}

Notional PCNAs with both $>\mathrm{C}(\mathrm{H}) \mathrm{C}(\mathrm{H})<$ and $>\mathrm{CH}_{2}$ groups were also built and modeled. Some representative examples are shown in Fig. 20. However, given the current state-of-the-art in synthesizing PCNAs with tris(nitramino)methane fragments, we did not consider such structures to warrant additional analysis at this time.
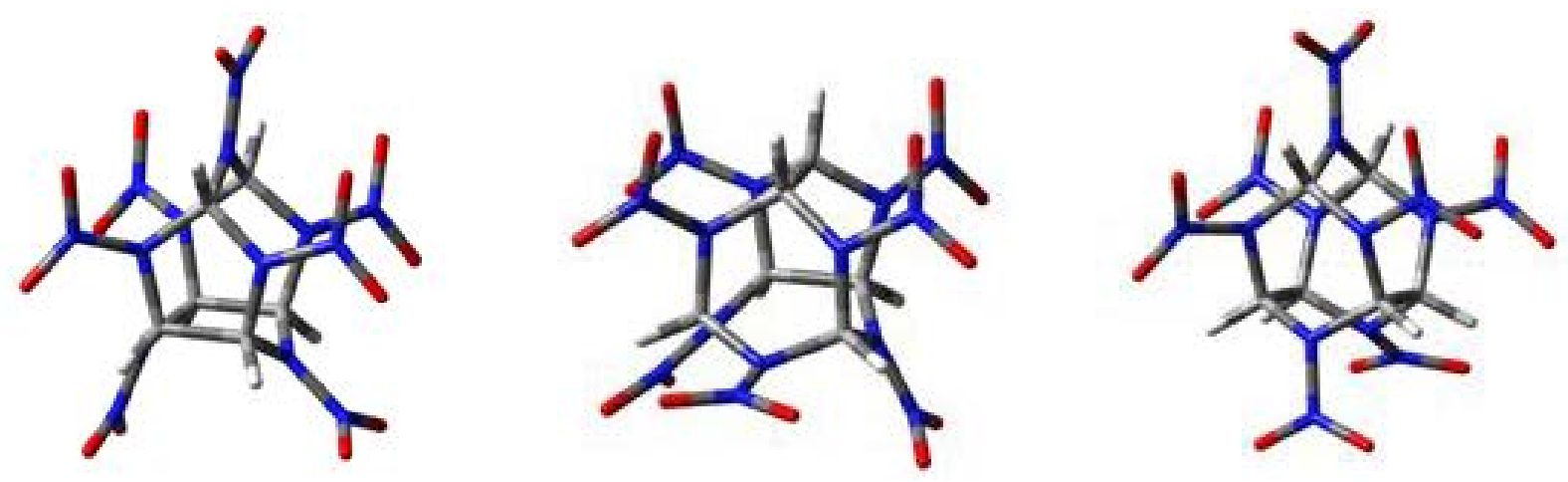

Fig. 20 Molecular structures for PCNAs with $\mathrm{C}_{6} \mathrm{H}_{6} \mathrm{~N}_{14} \mathrm{O}_{14}$ stoichiometry 


\section{Summary and Conclusions}

Searching for ingredients for propellants and explosives that have better performance properties and/or less sensitivity than RDX and HMX, we performed a computationally based study to assess the potential of cucurbiturils to be precursors for the synthesis of PCNAs. One scheme proposed for employing cucurbiturils in this role involved reducing them to cucurbitaminals, then nitrolyzing them (Scheme I). Another involved hydrolyzing them, then nitrating the secondary amine groups of the product (Scheme II).

In the case of Scheme I, one issue the study attempted to address was a concern that the cucurbitaminals would not be stable/isolable. Simple screening of bond lengths derived from molecular geometries produced with a B3LYP/6-31+G(d,p) model did not raise any particular concerns. However, bond lengths were found to be an inadequate basis for predicting differences in the stabilities of some known compounds. Thus, the question concerning the cucurbitaminals' stabilities is considered to remain open.

Another question the study attempted to answer concerned the likelihood that, when subjected to nitrolysis, the C-N bonds that need to break for Scheme I to work would indeed be those that broke. To obtain predictions, the cucurbitaminals were $\mathrm{N}$-protonated, and the lengths of the resulting $\mathrm{C}-\mathrm{N}\left(\mathrm{H}^{+}\right)$bonds compared. Our hypothesis was that the $\mathrm{C}-\mathrm{N}$ bonds most likely to break would be those corresponding to the longest $\mathrm{C}-\mathrm{N}\left(\mathrm{H}^{+}\right)$bonds. Some evidence that supports this hypothesis was found, and some additional tests of it are proposed. Regardless, the results obtained for the $\mathrm{N}$-protonation of cucurbitaminals were discouraging: the $\mathrm{C}-\mathrm{N}\left(\mathrm{H}^{+}\right)$bonds that need to break for cucurbitaminals to produce targeted PNCAs were found to be the shortest.

The stabilities and likelihoods of producing targeted intermediates were also a concern in the case of Scheme II. Again hypothesizing that the $\mathrm{C}-\mathrm{N}$ bond in a uril that would most likely break would be the one corresponding to the longest $\mathrm{C}-\mathrm{N}\left(\mathrm{H}^{+}\right)$bonds following $\mathrm{N}$-protonation, we modeled and compared them for noncage molecules and found some evidence to support the postulate. Other systems that would test this hypothesis were also identified. Regardless, the modeling results for the systems of interest were not encouraging. They suggest that the hydrolysis of cucurbiturils will not be regioselective, and therefore yields will be low (at best). In addition, results pertaining to the stabilities of the hydrolysis targets were not encouraging. Finally, bond lengths found for the targeted PCNAs suggested that they will not be stable. Taken together, the results indicate that the proposed synthesis approaches are unlikely to produce materials that will achieve Army objectives.

The attempt to answer questions regarding the feasibility of producing PCNAs from cucurbiturils prompted the design and modeling of a number of notional PCNAs besides the targets of the proposed schemes. One was a bicyclo-HMX polymorph (22) that more closely resembles 
$\beta$-HMX than a known polymorph (18). However, it was found that 22 will probably not be stable, and it is not likely to perform better than RDX or HMX. As such, an attempt at its synthesis is not considered warranted.

Another notional compound that was designed and modeled (23) contained a tris(nitramino)methane fragment. It was found that 23's performance will likely be inferior to that of either RDX or HMX. However, the results also suggest that $\mathbf{2 3}$ could be more stable than 4, which is the only compound with a tris(nitramino)-methane fragment that is known to have been isolated. Since 23's synthesis would surely provide insight into the nature of the tris(nitramino)methane fragment, it would likely provide insight into the possibility of synthesizing notional compounds with multiple tris(nitramino)methane fragments that are predicted to have exceptional performance potential. Therefore, an attempt at its synthesis is considered warranted.

Finally, a set of notional PCNAs was designed and modeled that, like CL-20, comprise just $>\mathrm{N}-\mathrm{NO}_{2}$ and $>\mathrm{CHCH}<$ fragments. Of the 7 that were examined closely, one (30) is intriguing. Its density, specific impulse, and bond lengths were predicted to be comparable to CL-20's, and its $H(298) / \mathrm{N}(\mathrm{C}-\mathrm{C})$ group estimate was lower. Thus, it appears to have the potential to equal CL-20's performance and be less sensitive. In addition, it was envisioned that $\mathbf{3 0}$ could be synthesized by nitrolyzing a precursor (31) that has HMTA's high degree of symmetry. Recalling the Bachmann process, if $\mathbf{3 1}$ could be produced simply/economically, $\mathbf{3 0}$ might also. 


\section{Notes}

1. For molecules with $\mathrm{C}_{w} \mathrm{H}_{x} \mathrm{~N}_{y} \mathrm{O}_{z}$ stoichiometry, "fuel-air" equivalence ratios $(\Phi)$ can be computed via the equation $\Phi=\frac{2 * w+0.5 * x}{z}$. A system is stoichiometric to $\mathrm{CO}_{2}$ and $\mathrm{H}_{2} \mathrm{O}$ when $\Phi=1.00$. For RDX, where $w=3$ and $x=z=6, \Phi=1.5$. For CL-20, where $w=x=6$ and $z=$ $12, \Phi=1.25$.

2. "In principle” is used in this report to qualify statements regarding the possibility of a product being formed from a set of reactants. When it is used, an empirical understanding of an established reaction mechanism is assumed to be extrapolable to the system being discussed. For example, it is assumed that any $2 \mathrm{~N}-\mathrm{H}$ groups can react with an aldehyde group to form a N-C-N group, and that the system can go to completion, creating a cage structure as it does in the case of $\mathrm{NH}_{3}+\mathrm{H}_{2} \mathrm{CO} \rightarrow$ HMTA.

3. Damavarapu R. US Army Armament Research Development and Engineering Center, Picatinny Arsenal, NJ. 


\section{References}

Adamo C, Barone V. Exchange functionals with improved long-range behavior and adiabatic connection methods without adjustable parameters: the mPW and mPW1PW models. Journal of Chemical Physics. 1998;108:664-675.

Agrawal JP. Recent trends in high-energy materials. Progress in Energy and Combustion Science 1998;24:1-30.

Alder RW, Harvey JN, Schleyer PvR, Moran D. $T_{h}$-Symmetrical $N_{8}(C=C)_{6}$ and $P_{8}(C=C)_{6}$ : an extraordinary contrast in heterofullerene stability. Organic Letters. 2001;3:3233-3236.

Alkorta I, Elguero J, Rozas I. Theoretical studies of aza analogues of platonic hydrocarbons. Part III. Dodecahedrane and its aza derivatives. Journal of Molecular Structure THEOCHEM. 1991;228:47-60.

Atavin EG, Golubinskii AV, Kravchenko AN, Lebedev OV, Vilkov LV. Electron diffraction study of molecular structure of mebicar. Journal of Structural Chemistry 2005;46:417-421.

Baboul AG, Curtiss LA, Redfern PC, Raghavachari K. Gaussian-3 theory using density functional geometries and zero-point energies. Journal of Chemical Physics. 1999;110:7650.

Bachmann WE, Sheehan JC. A new method of preparing the high explosive RDX. Journal of the American Chemical Society. 1949;71:1842.

Bardelang D, Udachin KA, Anedda R, Moudrakovski I, Leek DM, Ripmeester JA, Ratcliffe CI. Single-crystal to single-crystal phase transition of cucurbit[5]uril hydrochloride hydrates: large water-filled channels transforming to layers of unusual stability. Chemical Communications. 2008;4927.

Bardelang D, Udachin KA, Leek DM, Margeson JC, Chan G, Ratcliffe CI, Ripmeester JA. Cucurbit[n]urils ( $n=5-8)$ : a comprehensive solid state study. Crystal Growth and Design. 2011;11:5598-5614.

Bates HA, Condulis N, Stein NL. Reduction of cyclic ureas with lithium aluminum hydride. Journal of Organic Chemistry. 1986;51:2228-2229.

Becke AD. Density-functional exchange-energy approximation with correct asymptoticbehavior. Physical Review A. 1988;38:3098-3100.

Becke AD. Density-functional thermochemistry. 3. The role of exact exchange. Journal of Chemical Physics. 1993;98:5648-5652. 
Becke AD. Density-functional thermochemistry. IV. A new dynamical correlation functional and implications for exact-exchange mixing. Journal of Chemical Physics. 1996;104:1040-1046.

Byrd EFC. Simple computation of the heat of formation and density from theoretically predicted values. Aberdeen Proving Ground (MD): Army Research Laboratory (US); 2012. Report No.: ARL-TR-6206. Also available at http://www.arl.army.mil/www/default.cfm?technical_report=6572

Clark T, Chandrashakar J, Spitznagel GW, Schleyer PVR. Efficient diffuse function-augmented basis-sets for anion calculations. 3. The 3-21+G basis set for 1st-row elements, Li-F. Journal of Computational Chemistry. 1983;4:294-301.

Curtiss LA, Redfern PC, Raghavachari RV, Pople JA. Gaussian-3 theory using reduced MollerPlesset order. Journal of Chemical Physics. 1999;110,4703.

Curtiss LA, Redfern PC, Raghavachari K. Gaussian-4 theory. Journal of Chemical Physics. 2007;126:084108.Deschamps JR, Frisch M, Parrish D. Thermal expansion of HMX. Journal of Chemical Crystallography. 2011;41:971-975.

Deschamps JR, Frisch M, Parrish D. Thermal expansion of HMX. Journal of Chemical Crystallography. 2011;41:971-975.

Dzyabchenko AV, Pivina TS, Arnautova EA. Prediction of structure and density for organic nitramines. Journal of Molecular Structure. 1996;378:69-82.

Estrada E, Simon-Manso Y. Rational design and first principles studies toward the discovery of small and versatile proton sponge. Angewandte Chemie Int. Ed. 2006;45,1719-1721.

Franchimont APN, Klobbie EA. Les méthyl- et éthylamides de l'acide heptylique. Recueil des Travaux Chimiques des Pays-Bas. 1887;6,247-250.

Freeman WA, Mock WL, Shih NY. Cucurbituril. Journal of the American Chemical Society. 1981;103:7367-7368.

Flynn DL, Zelle RE, Grieco PA. A mild 2-step method for the hydrolysis/methanolysis of secondary amides and lactams. Journal of Organic Chemistry. 1983;48:2424-2426.

Frisch MJ, Trucks GW, Schlegel HB, Scuseria GE, Robb MA, Cheeseman JR, Scalmani G, Barone V, Mennucci B, Petersson GA, Nakatsuji H, Caricato M, Li X, Hratchian HP, Izmaylov AF, Bloino J, Zheng G, Sonnenberg JL, Hada M, Ehara M, Toyota K, Fukuda R, Hasegawa J, Ishida M, Nakajima T, Honda Y, Kitao O, Nakai H, Vreven T, Montgomery JA, Peralta JE, Ogliaro F, Bearpark M, Heyd JJ, Brothers E, Kudin KN, Staroverov VN, Keith T, Kobayashi R, Normand J, Raghavachari K, Rendell A, Burant JC, Iyengar SS, Tomasi J, Cossi M, Rega N, Millam JM, Klene M, Knox JE, Cross JB, Bakken V, Adamo C, Jaramillo J, Gomperts R, Stratmann RE, Yazyev O, Austin AJ, Cammi R, Pomelli C, Ochterski JW, Martin RL, Morokuma K, Zakrzewski VG, Voth GA, Salvador P, 
Dannenberg JJ, Dapprich S, Daniels AD, Farkas O, Foresman JB, Ortiz JV, Cioslowski J, Fox DJ. Gaussian 09. Rev. D.01. Wallingford (CT): Gaussian, Inc. 2009.

Geissman TA, Schlatter MJ, Webb ID. The preparation of 1,3-diaminopropane and 1,3,-diamino2-(aminomethyl)propane. Journal of Organic Chemistry. 1946;11:736-740.

Gilardi R, Flippen-Anderson JL, Evans R. cis-2,4,6,8-Tetranitro-1H,5H-2,4,6,8-tetraazabicyclo[3.3.0]octane, the energetic compound 'bicyclo-HMX.' Acta Crystallographica, Sect. E. 2002;58:972.

Gotthardt H, Blum J. Syntheses of 2,6,7-Triazabicyclo[2.2.2]oct-2-ene-5,8-diones and 3,4dihydro-4-pyrimidinones via 1,4-dipolar cycloaddition reactions of pyrimidinium-4-olates to nitriles. Chemische Berichte-Recueil. 1986;119:1445-1454.

Ju X-H, Wang Z-Y. Prediction of caged polyaza polynitramine (tetracyclo-HMX) as energetic compound. Journal of Energetic Materials. 2009;27:133-143.

Katritzky AR, Rogers JW, Witek RM, Vakulenko AV, Mohapatra PP, Steel PJ, Damavarapu R. Synthesis and characterization of blowing agents and hypergolics. Journal of Energetic Materials. 2007;25:79-109.

Koppes WM, Chaykovsky M, Adolph HG, Gilardi R, George C. Synthesis and structure of some peri-substituted 2,4,6,8-tetraazabicyclo[3.3.0]octanes. Journal of Organic Chemistry. 1987;52:1113-1119.

Lee CT, Yang WT, Parr RG. Development of the Colle-Salvetti correlation-energy formula into a functional of the electron-density. Physical Review B. 1988;37:785-789.

Luk’yanov OA, Seregina NM, Tartakovskii VA. Nitration of tetraalkyl-substituted methylenediamine derivatives with nitronium tetrafluoborate and nitrogen pentoxide. Bulletin of the Academy of Sciences of The USSR, Division of Chemical Science. 1976;25:220-221.

Masson E, Ling X, Joseph RL, Kyeremeh-Mensah L, Lu X. Cucurbituril chemistry: a tale of supramolecular success. RSC Advances. 2012;2:1213-1247.

McQuaid MJ, Drake GW. The design and characterization of alipolycyclic amines with the potential to be precursors for the affordable production of notional nitramines. Aberdeen Proving Ground (MD): Army Research Laboratory (US); 2009. Report No.: ARL-TR-4695.

McQuaid MJ, Stevenson WH, Thompson DM. The structure of saturated, (all) tertiary, alkyl multiamines: characteristics of known and notional hypergols. Aberdeen Proving Ground (MD): Army Research Laboratory (US); 2005. Report No.: ARL-TR-3412.

Miehlich B, Savin A, Stoll H, Preuss H. Results obtained with the correlation-energy density functionals of Becke and Lee, Yang and Parr. Chemical Physics Letters. 1989;157:200-206. 
Montgomery JA, Frisch MJ, Ochterski JW, Petersson GA. A complete basis set model chemistry. VII. Use of minimum population localization method. Journal of Chemical Physics. 2000;112:6532.

Nelsen SF, Hintz PJ. Electrochemical oxidation of tertiary amines. The effect of structure upon reversibility. Journal of the American Chemical Society. 1972;94:7114-7117.

Nielsen AT, Chaffin AP, Christian SL, Moore DW, Nadler MP, Nissan, RA, Vanderah DJ, Gilardi RD, George CF, Flippen-Anderson JL. Synthesis of polyazapolycyclic caged polynitramines. Tetrahedron. 1998;54:11793-11812.

Pagoria PF, Mitchell AR, Schmidt RD, Coon CL, Jessop ES. New nitration and nitrolysis procedures in the synthesis of energetic materials. In: Albright LF, Carr RVC, Schmitt RJ, editors. Nitration: recent laboratory and industrial developments. ACS Symposium Series 623. Washington (DC): American Chemical Society; 1996.

Petersson GA, Bennett A, Tensfeldt TG, Al-Laham MA, Shirley WA, Mantzaris JA. Complete basis set model chemistry. 1 . The total energies of closed-shell atoms and hydrides of the 1st-row elements. Journal of Chemical Physics. 1988;89:2193-2218.

Petersson GA, Al-Laham MA. A complete basis set model chemistry. I. Open-shell systems and the total energies of the $1^{\text {st }}$ row atoms. Journal of Chemical Physics. 1991;94:6081-6090.

Pivina TS, Shcherbukhin VV, Molchanova MS, Zefirov NS. Computer-assisted prediction of novel target high-energy compounds. Propellants, Explosives and Pyrotechnics. 1995;20:144-146.

Rice BM, Pai SV, Hare J. Predicting heats of formation of energetic materials using quantum mechanical calculations. Combustion and Flame. 1999;118:445-458.

Stancl M, Necas M, Taraba J, Sindelar V. Glycoluril dimers bearing hydrogen atoms on their convex face and their self-assembly in the solid state. Journal of Organic Chemistry. 2008;73:4671-4675.

Stephens PJ, Devlin FJ, Chabalowski CF, Frisch MJ. Ab-initio calculation of vibrational absorption and circular-dichroism spectra using density-functional force-fields. Journal of Physical Chemistry. 1994;98:11623-11627.

Sysolyatin SV, Sakovich GV, Sumachev VN. Methods for the synthesis of polycyclic nitramines. Russian Chemical Reviews. 2007;76:673-680.

Sysolyatin SV, Sakovich GV, Chernikova YT, Surmachev VN, Lobanova AA. Synthesis of polycyclic nitramines by nitration of condensation products of glyoxal and formaldehyde with sulfamic acid salts. The 37th Annual Conference of ICT; 2006; Karlsruhe, Germany. p. 141/1. 
Von Herz E, inventor. Improvements Relating to Explosives. British patent 145,791. 1921.

Vosko SH, Wilk L, Nusair M. Accurate spin-dependent electron liquid correlation energies for local spin-density calculations - a critical analysis. Canadian Journal of Physics. 1980;58:1200-1211.

Zhao G, Lu M. Computational studies on 3,5,7,12,14,16-octanitro-3,5,7,10,12,14,15,16-octaazapentacyclo[7.5.1.1 $1^{2,8} \cdot 0^{4,13} \cdot 0^{6,11}$ ] hexadecane as potential high-energy-density compound. Structural Chemistry. 2013;24:139-145.

Zhang J, Du H, Wang F, Gong X, Ying S. Crystal structure, detonation performance, and thermal stability of a new polynitro cage compound: 2, 4, 6, 8, 10, 12, 13, 14, 15-nonanitro-2, 4, 6, 8, 10, 12, 13, 14, 15-nonaazaheptacyclo [5.5.1.13, 11. 15, 9] pentadecane. Journal of Molecular Modeling. 2012;18:2369-2376. 
INTENTIONALLY LEFT BLANK. 
Appendix A. B3LYP/6-31G(p,d)-Based Geometries and 0.001 Electron/Bohr ${ }^{3}$ Isosurface Parameters 
This appendix provides Cartesian coordinate representations for all the molecular structures modeled in this study. The structures were obtained with a B3LYP/6-31+G(d,p) model. In addition, parameters of the 0.001 electron/bohr ${ }^{3}$ isosurface for various molecules are included. These parameters were employed to derive density and enthalpy of sublimation estimates. 


\begin{tabular}{|c|c|c|c|c|c|c|c|}
\hline 1 & & & & 2 & & & \\
\hline C & 0.000 & -0.010 & 0.008 & $\mathrm{~N}$ & 0.000 & -0.001 & -0.001 \\
\hline $\mathrm{H}$ & 0.003 & -0.015 & 1.094 & C & -0.001 & -0.001 & 1.465 \\
\hline C & 1.415 & 0.000 & -1.982 & $\mathrm{~N}$ & 1.337 & -0.001 & 2.020 \\
\hline $\mathrm{H}$ & 2.437 & 0.023 & -2.343 & C & 2.289 & 1.063 & 1.775 \\
\hline C & -0.739 & 1.163 & -2.013 & $\mathrm{~N}$ & 2.610 & 1.215 & 0.352 \\
\hline $\mathrm{H}$ & -1.287 & 2.028 & -2.375 & C & 2.117 & 2.241 & -0.547 \\
\hline C & -0.676 & -1.276 & -1.977 & $\mathrm{~N}$ & 1.952 & 3.494 & 0.176 \\
\hline $\mathrm{H}$ & -1.161 & -2.180 & -2.330 & C & 1.284 & 3.450 & 1.469 \\
\hline $\mathrm{N}$ & -0.664 & 1.175 & -0.534 & $\mathrm{~N}$ & 1.819 & 2.362 & 2.266 \\
\hline $\mathrm{N}$ & -0.721 & -1.187 & -0.518 & $\mathrm{~N}$ & -0.172 & 3.442 & 1.350 \\
\hline $\mathrm{N}$ & -1.318 & -0.080 & -2.521 & $\mathrm{C}$ & -1.109 & 2.339 & 1.147 \\
\hline $\mathrm{N}$ & 1.364 & 0.073 & $\begin{array}{l}-0.525 \\
-2395\end{array}$ & $\mathrm{~N}$ & -1.274 & 1.996 & -0.258 \\
\hline $\begin{array}{l}\mathrm{N} \\
\mathrm{N}\end{array}$ & $\begin{array}{l}0.737 \\
0.642\end{array}$ & $\begin{array}{r}-1.235 \\
1.141\end{array}$ & $\begin{array}{l}-2.395 \\
-2.508\end{array}$ & C & -0.275 & 1.129 & -0.868 \\
\hline $\mathrm{N}$ & $\begin{array}{r}0.042 \\
-1.807\end{array}$ & $\begin{array}{l}1.141 \\
1.642\end{array}$ & 0.189 & $\mathrm{~N}$ & -0.796 & 1.147 & 1.912 \\
\hline $\mathrm{O}$ & -1.893 & 1.270 & 1.348 & $\mathrm{H}$ & -2.071 & 2.713 & 1.494 \\
\hline $\mathrm{O}$ & -2.536 & 2.407 & -0.414 & $\mathrm{~N}$ & 0.918 & 1.859 & -1.290 \\
\hline $\mathrm{N}$ & 1.318 & 2.408 & -2.462 & $\mathrm{H}$ & -0.465 & -0.921 & 1.822 \\
\hline $\mathrm{O}$ & 2.535 & 2.358 & -2.444 & $\mathrm{H}$ & -0.714 & 0.742 & -1.787 \\
\hline $\mathrm{O}$ & 0.603 & 3.394 & -2.503 & $\mathrm{H}$ & 1.525 & 4.382 & 1.979 \\
\hline $\mathrm{N}$ & -0.608 & -2.419 & 0.205 & $\mathrm{H}$ & 2.880 & 2.413 & -1.304 \\
\hline $\mathrm{O}$ & -0.386 & -2.312 & 1.397 & $\mathrm{H}$ & 3.191 & 0.779 & 2.319 \\
\hline $\mathrm{O}$ & -0.807 & -3.435 & -0.439 & $\mathrm{~N}$ & 0.203 & -1.256 & -0.636 \\
\hline $\mathrm{N}$ & 2.414 & -0.560 & 0.209 & $\mathrm{O}$ & 0.239 & -1.237 & -1.856 \\
\hline $\mathrm{O}$ & 3.401 & -0.869 & -0.438 & $\mathrm{O}$ & 0.334 & -2.214 & 0.107 \\
\hline $\mathrm{O}$ & 2.232 & -0.667 & 1.408 & $\mathrm{~N}$ & 3.512 & 0.269 & -0.197 \\
\hline $\mathrm{N}$ & 0.981 & -1.641 & -3.753 & $\mathrm{O}$ & 3.968 & -0.549 & 0.586 \\
\hline $\mathrm{O}$ & 0.147 & -2.379 & -4.244 & $\mathrm{O}$ & 3.726 & 0.367 & -1.395 \\
\hline $\mathrm{O}$ & 2.023 & -1.246 & -4.245 & $\mathrm{~N}$ & 1.740 & -1.111 & 2.852 \\
\hline $\mathrm{N}$ & -2.727 & -0.124 & -2.755 & $\mathrm{O}$ & 2.869 & -1.059 & 3.298 \\
\hline $\mathrm{O}$ & -3.237 & -1.231 & -2.710 & $\mathrm{O}$ & 0.908 & -1.980 & 3.020 \\
\hline $\mathrm{O}$ & -3.251 & 0.939 & -3.032 & $\mathrm{~N}$ & 0.839 & 2.410 & -2.605 \\
\hline & & & & $\mathrm{O}$ & -0.176 & 2.162 & -3.236 \\
\hline & & & & $\mathrm{O}$ & 1.791 & 3.080 & -2.970 \\
\hline & & & & $\mathrm{N}$ & -2.651 & 1.630 & -0.608 \\
\hline & & & & $\mathrm{O}$ & -3.519 & 2.047 & 0.134 \\
\hline & & & & $\mathrm{O}$ & -2.789 & 0.986 & -1.630 \\
\hline & & & & $\mathrm{N}$ & -0.765 & 4.740 & 1.280 \\
\hline & & & & $\mathrm{O}$ & -0.005 & 5.689 & 1.385 \\
\hline & & & & $\mathrm{O}$ & -1.974 & 4.775 & 1.117 \\
\hline & & & & $\mathrm{N}$ & 3.160 & 4.326 & 0.175 \\
\hline & & & & $\mathrm{O}$ & 3.225 & 5.174 & 1.044 \\
\hline & & & & $\mathrm{O}$ & 3.953 & 4.116 & -0.721 \\
\hline & & & & $\mathrm{N}$ & -1.350 & 1.064 & 3.215 \\
\hline & & & & $\mathrm{O}$ & -1.970 & 2.044 & 3.597 \\
\hline & & & & $\mathrm{O}$ & -1.138 & 0.025 & 3.819 \\
\hline & & & & $\mathrm{N}$ & 1.966 & 2.605 & 3.658 \\
\hline & & & & $\mathrm{O}$ & 2.496 & 1.714 & 4.301 \\
\hline & & & & $\mathrm{O}$ & 1.534 & 3.672 & 4.063 \\
\hline
\end{tabular}




\begin{tabular}{|c|c|c|c|c|c|c|c|c|c|c|c|}
\hline 3 & & & & & & & & 4 & & & \\
\hline $\mathrm{H}$ & 0.000 & 0.000 & 0.000 & $\mathrm{O}$ & -3.873 & -0.993 & 1.560 & $\mathrm{~N}$ & 0.359 & -0.255 & 0.039 \\
\hline $\mathrm{C}$ & 0.000 & 0.000 & 1.092 & $\mathrm{O}$ & -4.300 & 0.739 & 2.829 & $\mathrm{C}$ & 0.202 & -0.134 & 1.493 \\
\hline $\mathrm{N}$ & 1.406 & 0.000 & 1.472 & $\mathrm{~N}$ & -1.642 & -3.222 & 4.316 & $\mathrm{~N}$ & 1.536 & 0.007 & 2.086 \\
\hline $\mathrm{C}$ & 2.068 & -0.610 & 2.616 & $\mathrm{O}$ & -1.077 & -3.853 & 5.194 & $\mathrm{C}$ & 2.311 & 1.157 & 1.549 \\
\hline $\mathrm{N}$ & 1.442 & -1.849 & 3.054 & $\mathrm{O}$ & -2.788 & -3.356 & 3.922 & $\mathrm{C}$ & 2.434 & 0.996 & 0.021 \\
\hline $\mathrm{C}$ & 0.506 & -2.093 & 4.142 & $\mathrm{~N}$ & -2.294 & -0.526 & 6.278 & $\mathrm{C}$ & 1.022 & 0.918 & -0.590 \\
\hline $\mathrm{N}$ & -0.880 & -2.172 & 3.704 & $\mathrm{O}$ & -1.768 & -0.992 & 7.275 & $\mathrm{C}$ & 0.206 & 2.182 & -0.257 \\
\hline $\mathrm{C}$ & -1.561 & -1.484 & 2.616 & $\mathrm{O}$ & -3.483 & -0.488 & 6.010 & $\mathrm{C}$ & 0.110 & 2.328 & 1.274 \\
\hline $\mathrm{N}$ & -0.702 & -1.217 & 1.472 & $\mathrm{~N}$ & -0.707 & -2.243 & 0.469 & $\mathrm{~N}$ & -0.553 & 1.092 & 1.771 \\
\hline $\mathrm{N}$ & 0.704 & -1.214 & 5.285 & $\mathrm{O}$ & -1.339 & -3.251 & 0.735 & C & 1.510 & 2.423 & 1.909 \\
\hline $\mathrm{C}$ & 0.000 & 0.003 & 5.665 & $\mathrm{O}$ & -0.049 & -2.018 & -0.533 & $\mathrm{H}$ & 1.430 & 2.528 & 2.995 \\
\hline $\mathrm{N}$ & -1.406 & 0.003 & 5.284 & $\mathrm{~N}$ & -1.971 & 3.037 & 4.313 & $\mathrm{H}$ & 3.283 & 1.153 & 2.039 \\
\hline $\mathrm{C}$ & -2.068 & 0.612 & 4.140 & $\mathrm{O}$ & -1.509 & 4.095 & 3.921 & $\mathrm{H}$ & 2.966 & 1.854 & -0.404 \\
\hline $\mathrm{N}$ & -2.322 & -0.321 & 3.052 & $\mathrm{O}$ & -2.805 & 2.865 & 5.186 & $\mathrm{H}$ & 3.006 & 0.096 & -0.222 \\
\hline $\mathrm{N}$ & 0.702 & 1.220 & 5.285 & $\mathrm{~N}$ & 1.642 & 3.225 & 2.440 & $\mathrm{H}$ & -0.521 & 3.170 & 1.551 \\
\hline $\mathrm{C}$ & 1.561 & 1.487 & 4.140 & $\mathrm{O}$ & 1.077 & 3.856 & 1.562 & $\mathrm{H}$ & -0.793 & 2.118 & -0.698 \\
\hline $\mathrm{N}$ & 0.880 & 2.174 & 3.052 & $\mathrm{O}$ & 2.788 & 3.359 & 2.834 & $\mathrm{H}$ & 0.699 & 3.067 & -0.675 \\
\hline $\mathrm{C}$ & -0.506 & 2.096 & 2.615 & $\mathrm{~N}$ & 2.294 & 0.528 & 0.478 & $\mathrm{H}$ & 1.066 & 0.732 & -1.661 \\
\hline $\mathrm{N}$ & -1.442 & 1.852 & 3.703 & $\mathrm{O}$ & 3.483 & 0.490 & 0.745 & $\mathrm{H}$ & 2.036 & 3.305 & 1.527 \\
\hline $\mathrm{N}$ & -0.704 & 1.216 & 1.472 & $\mathrm{O}$ & 1.768 & 0.994 & -0.519 & $\mathrm{H}$ & -0.308 & -0.999 & 1.897 \\
\hline $\mathrm{N}$ & 2.322 & 0.324 & 3.704 & $\mathrm{~N}$ & 1.971 & -3.034 & 2.444 & $\mathrm{~N}$ & -0.751 & -0.797 & -0.640 \\
\hline $\mathrm{H}$ & 2.306 & 2.197 & 4.503 & $\mathrm{O}$ & 1.510 & -4.093 & 2.836 & $\mathrm{O}$ & -1.526 & -1.480 & 0.018 \\
\hline $\mathrm{H}$ & -0.748 & 3.096 & 2.250 & $\mathrm{O}$ & 2.805 & -2.863 & 1.570 & $\mathrm{O}$ & -0.812 & -0.581 & -1.847 \\
\hline $\mathrm{H}$ & 3.056 & -0.900 & 2.253 & $\mathrm{~N}$ & 3.610 & 0.190 & 4.319 & $\mathrm{~N}$ & -1.142 & 1.158 & 3.049 \\
\hline $\mathrm{H}$ & 0.747 & -3.093 & 4.506 & $\mathrm{O}$ & 4.299 & -0.737 & 3.928 & $\mathrm{O}$ & -1.456 & 2.274 & 3.450 \\
\hline $\mathrm{H}$ & -2.307 & -2.194 & 2.253 & $\mathrm{O}$ & 3.872 & 0.995 & 5.197 & $\mathrm{O}$ & -1.339 & 0.095 & 3.625 \\
\hline $\mathrm{H}$ & -3.056 & 0.903 & 4.503 & $\mathrm{~N}$ & 0.707 & 2.246 & 6.288 & $\mathrm{~N}$ & 2.239 & -1.200 & 2.274 \\
\hline $\mathrm{H}$ & 0.000 & 0.003 & 6.757 & $\mathrm{O}$ & 0.050 & 2.021 & 7.290 & $\mathrm{O}$ & 3.455 & -1.108 & 2.416 \\
\hline $\mathrm{N}$ & 1.588 & -1.731 & 6.290 & $\mathrm{O}$ & 1.340 & 3.254 & 6.022 & $\mathrm{O}$ & 1.575 & -2.227 & 2.335 \\
\hline $\mathrm{O}$ & 1.721 & -1.048 & 7.292 & $\mathrm{~N}$ & -1.588 & 1.733 & 0.466 & & & & \\
\hline $\mathrm{O}$ & 2.144 & -2.784 & 6.027 & $\mathrm{O}$ & -2.145 & 2.786 & 0.730 & & & & \\
\hline $\mathrm{N}$ & -3.610 & -0.188 & 2.438 & $\mathrm{O}$ & -1.722 & 1.050 & -0.535 & & & & \\
\hline
\end{tabular}




\begin{tabular}{|c|c|c|c|c|c|c|c|c|c|c|c|}
\hline 5 & & & & 6 & & & & $6-\mathrm{H}^{-}$ & & & \\
\hline $\mathrm{H}$ & -0.848 & -0.693 & 1.658 & C & 0.000 & -0.002 & 0.000 & C & 0.291 & 0.058 & 0.068 \\
\hline C & -0.027 & 0.007 & 1.844 & $\mathrm{~N}$ & -0.002 & 0.027 & 1.399 & $\mathrm{~N}$ & 0.112 & 0.866 & 1.367 \\
\hline $\mathrm{N}$ & 0.904 & -0.008 & 0.734 & C & 1.105 & 0.037 & 2.279 & C & 1.252 & 0.459 & 2.418 \\
\hline C & 1.603 & 1.140 & 0.382 & $\mathrm{~N}$ & 0.540 & -0.012 & 3.575 & $\mathrm{~N}$ & 0.606 & 0.422 & 3.604 \\
\hline $\mathrm{O}$ & 1.290 & 2.292 & 0.660 & C & -0.920 & 0.134 & 3.550 & C & -0.814 & 0.811 & 3.564 \\
\hline $\mathrm{N}$ & 2.722 & 0.747 & -0.342 & C & -1.266 & -0.224 & 2.100 & $\mathrm{C}$ & -1.183 & 0.636 & 2.088 \\
\hline C & 2.637 & -0.670 & -0.669 & $\mathrm{H}$ & -1.200 & 1.164 & 3.800 & $\mathrm{H}$ & -0.929 & 1.841 & 3.914 \\
\hline C & 1.697 & -1.192 & 0.432 & $\mathrm{H}$ & -1.382 & -0.532 & 4.278 & $\mathrm{H}$ & -1.395 & 0.160 & 4.216 \\
\hline $\mathrm{H}$ & 3.620 & -1.150 & -0.648 & $\mathrm{H}$ & -2.062 & 0.395 & 1.686 & $\mathrm{H}$ & -1.943 & 1.336 & 1.738 \\
\hline $\mathrm{H}$ & 2.198 & -0.819 & -1.670 & $\mathrm{H}$ & -1.557 & -1.275 & 1.992 & $\mathrm{H}$ & -1.481 & -0.388 & 1.861 \\
\hline $\mathrm{H}$ & 2.267 & -1.522 & 1.317 & C & 1.193 & 0.020 & 4.812 & $\mathrm{C}$ & 1.204 & 0.143 & 4.903 \\
\hline $\mathrm{H}$ & 1.070 & -2.023 & 0.095 & $\mathrm{O}$ & -1.028 & -0.250 & -0.611 & $\mathrm{O}$ & -0.130 & -1.061 & 0.033 \\
\hline $\mathrm{H}$ & 0.463 & -0.267 & 2.791 & $\mathrm{O}$ & 1.192 & 0.291 & -0.510 & $\mathrm{O}$ & 0.915 & 0.826 & -0.766 \\
\hline $\mathrm{H}$ & -0.429 & 1.017 & 1.936 & C & 1.435 & 0.274 & -1.975 & C & 1.368 & 0.319 & -2.169 \\
\hline C & 3.396 & 1.680 & -1.222 & C & 0.570 & 1.337 & -2.658 & C & 0.113 & -0.037 & -2.955 \\
\hline $\mathrm{H}$ & 3.252 & 2.686 & -0.825 & $\mathrm{H}$ & 0.855 & 1.408 & -3.713 & $\mathrm{H}$ & 0.411 & -0.301 & -3.975 \\
\hline $\mathrm{H}$ & 4.467 & 1.457 & -1.259 & $\mathrm{H}$ & -0.490 & 1.089 & -2.597 & $\mathrm{H}$ & -0.410 & -0.894 & -2.527 \\
\hline $\mathrm{H}$ & 2.992 & 1.641 & -2.245 & $\mathrm{H}$ & 0.735 & 2.317 & -2.197 & $\mathrm{H}$ & -0.569 & 0.816 & -3.019 \\
\hline & & & & C & 1.182 & -1.133 & -2.524 & $\mathrm{C}$ & 2.314 & -0.854 & -1.949 \\
\hline $5-\mathrm{H}^{+}$ & & & & $\mathrm{H}$ & 1.486 & -1.168 & -3.576 & $\mathrm{H}$ & 2.736 & -1.139 & -2.918 \\
\hline $\mathrm{H}$ & -0.251 & -0.473 & 0.195 & $\mathrm{H}$ & 1.778 & -1.869 & -1.975 & $\mathrm{H}$ & 3.141 & -0.575 & -1.291 \\
\hline C & -0.058 & -0.099 & 1.201 & $\mathrm{H}$ & 0.128 & -1.404 & -2.457 & $\mathrm{H}$ & 1.800 & -1.725 & -1.539 \\
\hline $\mathrm{N}$ & 1.417 & 0.144 & 1.349 & C & 2.919 & 0.637 & -2.056 & C & 2.076 & 1.551 & -2.715 \\
\hline C & 1.768 & 0.820 & 2.727 & $\mathrm{H}$ & 3.525 & -0.095 & -1.515 & $\mathrm{H}$ & 2.928 & 1.829 & -2.089 \\
\hline $\mathrm{O}$ & 1.038 & 1.649 & 3.192 & $\mathrm{H}$ & 3.239 & 0.656 & -3.102 & $\mathrm{H}$ & 2.450 & 1.327 & -3.719 \\
\hline $\mathrm{N}$ & 2.925 & 0.270 & 3.106 & $\mathrm{H}$ & 3.100 & 1.622 & -1.616 & $\mathrm{H}$ & 1.393 & 2.402 & -2.789 \\
\hline C & 3.506 & -0.682 & 2.157 & $\mathrm{O}$ & 0.553 & 0.177 & 5.840 & $\mathrm{O}$ & 0.498 & 0.245 & 5.878 \\
\hline C & 2.311 & -1.064 & 1.272 & $\mathrm{O}$ & 2.505 & -0.162 & 4.697 & $\mathrm{O}$ & 2.459 & -0.187 & 4.773 \\
\hline $\mathrm{H}$ & 3.907 & -1.552 & 2.682 & C & 3.399 & -0.143 & 5.881 & $\mathrm{C}$ & 3.328 & -0.530 & 5.982 \\
\hline $\mathrm{H}$ & 4.319 & -0.214 & 1.590 & C & 3.039 & -1.298 & 6.820 & C & 2.740 & -1.761 & 6.666 \\
\hline $\mathrm{H}$ & 1.753 & -1.902 & 1.693 & $\mathrm{H}$ & 3.783 & -1.356 & 7.621 & $\mathrm{H}$ & 3.425 & -2.082 & 7.457 \\
\hline $\mathrm{H}$ & 2.573 & -1.280 & 0.236 & $\mathrm{H}$ & 2.054 & -1.155 & 7.268 & $\mathrm{H}$ & 1.771 & -1.551 & 7.123 \\
\hline $\mathrm{H}$ & -0.365 & -0.829 & 1.949 & $\mathrm{H}$ & 3.051 & -2.249 & 6.277 & $\mathrm{H}$ & 2.636 & -2.589 & 5.958 \\
\hline $\mathrm{H}$ & -0.572 & 0.847 & 1.372 & C & 4.774 & -0.360 & 5.245 & C & 4.669 & -0.830 & 5.321 \\
\hline $\begin{array}{l}\mathrm{C} \\
\mathrm{H}\end{array}$ & $\begin{array}{l}3.637 \\
3011\end{array}$ & 0.710 & 4.310 & $\mathrm{H}$ & 5.545 & -0.362 & 6.022 & $\mathrm{H}$ & 5.398 & -1.096 & 6.092 \\
\hline $\begin{array}{l}\mathrm{H} \\
\mathrm{H}\end{array}$ & $\begin{array}{l}3.011 \\
3.834\end{array}$ & $\begin{array}{r}1.428 \\
-0.151\end{array}$ & $\begin{array}{l}4.840 \\
4.954\end{array}$ & $\mathrm{H}$ & 4.808 & -1.315 & 4.714 & $\mathrm{H}$ & 4.585 & -1.667 & 4.623 \\
\hline $\mathrm{H}$ & 4.583 & 1.184 & $\begin{array}{l}4.034 \\
4.032\end{array}$ & $\mathrm{H}$ & 4.997 & 0.436 & 4.529 & $\mathrm{H}$ & 5.044 & 0.043 & 4.779 \\
\hline \multirow{6}{*}{$\mathrm{H}$} & 1.693 & 0.828 & 0.634 & C & 3.322 & 1.222 & 6.571 & C & 3.398 & 0.693 & 6.892 \\
\hline & & & & $\mathrm{H}$ & 3.529 & 2.024 & 5.854 & $\mathrm{H}$ & 3.758 & 1.568 & 6.341 \\
\hline & & & & $\mathrm{H}$ & 2.342 & 1.389 & 7.020 & $\mathrm{H}$ & 2.432 & 0.921 & 7.345 \\
\hline & & & & $\mathrm{H}$ & 4.081 & 1.268 & 7.359 & $\mathrm{H}$ & 4.111 & 0.489 & 7.696 \\
\hline & & & & $\mathrm{O}$ & 2.275 & 0.078 & 1.988 & $\mathrm{O}$ & 2.363 & 0.285 & 2.030 \\
\hline & & & & & & & & $\mathrm{H}$ & 0.270 & 1.854 & 1.136 \\
\hline
\end{tabular}




\begin{tabular}{|c|c|c|c|c|c|c|c|c|c|c|c|}
\hline \multicolumn{4}{|l|}{7} & \multicolumn{4}{|c|}{ 8gss } & \multicolumn{4}{|c|}{ 8gss-H ${ }^{+} \_$N2 } \\
\hline $\mathrm{C}$ & 0.026 & -0.027 & 0.006 & $\mathrm{C}$ & -0.015 & 0.045 & 0.022 & C & -0.056 & -0.020 & -0.062 \\
\hline $\mathrm{N}$ & 0.012 & 0.095 & 1.391 & $\mathrm{~N}$ & 0.029 & -0.019 & 1.403 & $\mathrm{~N}$ & -0.087 & -0.153 & 1.343 \\
\hline $\mathrm{C}$ & 1.338 & 0.058 & 1.964 & $\mathrm{C}$ & 1.379 & 0.004 & 1.913 & $\mathrm{C}$ & 1.204 & -0.130 & 1.892 \\
\hline $\mathrm{N}$ & 1.819 & -1.250 & 2.384 & $\mathrm{~N}$ & 1.946 & -1.275 & 2.321 & $\mathrm{~N}$ & 1.700 & -1.535 & 2.344 \\
\hline $\mathrm{C}$ & 3.047 & -1.576 & 1.818 & $\mathrm{C}$ & 3.159 & -1.513 & 1.679 & $\mathrm{C}$ & 3.086 & -1.744 & 1.682 \\
\hline $\mathrm{N}$ & 3.352 & -0.560 & 0.919 & $\mathrm{~N}$ & 3.342 & -0.524 & 0.730 & $\mathrm{~N}$ & 3.258 & -0.730 & 0.822 \\
\hline $\mathrm{C}$ & 2.252 & 0.355 & 0.721 & $\mathrm{C}$ & 2.223 & 0.384 & 0.655 & $\mathrm{C}$ & 2.143 & 0.207 & 0.699 \\
\hline $\mathrm{N}$ & 1.357 & 0.053 & -0.387 & $\mathrm{~N}$ & 1.289 & 0.180 & -0.445 & $\mathrm{~N}$ & 1.284 & 0.026 & -0.448 \\
\hline $\mathrm{H}$ & 2.606 & 1.390 & 0.683 & $\mathrm{H}$ & 2.577 & 1.425 & 0.660 & $\mathrm{H}$ & 2.542 & 1.229 & 0.751 \\
\hline $\mathrm{H}$ & 1.440 & 0.801 & 2.762 & $\mathrm{H}$ & 1.461 & 0.731 & 2.735 & $\mathrm{H}$ & 1.328 & 0.520 & 2.762 \\
\hline $\mathrm{O}$ & 3.733 & -2.547 & 2.079 & $\mathrm{C}$ & 4.433 & -0.562 & -0.223 & C & 4.487 & -0.620 & 0.024 \\
\hline $\mathrm{O}$ & -0.942 & -0.152 & -0.722 & $\mathrm{H}$ & 4.135 & -1.004 & -1.181 & $\mathrm{H}$ & 4.336 & -1.027 & -0.978 \\
\hline $\mathrm{H}$ & 4.027 & -0.755 & 0.193 & $\mathrm{H}$ & 4.809 & 0.452 & -0.399 & $\mathrm{H}$ & 4.774 & 0.432 & -0.042 \\
\hline $\mathrm{H}$ & 1.610 & -1.631 & 3.296 & $\mathrm{H}$ & 5.231 & -1.171 & 0.206 & $\mathrm{H}$ & 5.275 & -1.183 & 0.525 \\
\hline $\mathrm{H}$ & -0.799 & -0.242 & 1.890 & $\mathrm{C}$ & 1.529 & 0.731 & -1.769 & C & 1.641 & 0.517 & -1.779 \\
\hline $\mathrm{H}$ & 1.548 & 0.361 & -1.330 & $\mathrm{H}$ & 1.807 & 1.794 & -1.717 & $\mathrm{H}$ & 2.002 & 1.552 & -1.733 \\
\hline & & & & $\mathrm{H}$ & 2.323 & 0.184 & -2.285 & $\mathrm{H}$ & 2.403 & -0.118 & -2.236 \\
\hline & & & & $\mathrm{H}$ & 0.605 & 0.634 & -2.340 & $\mathrm{H}$ & 0.740 & 0.483 & -2.394 \\
\hline & & & & $\mathrm{C}$ & -1.144 & -0.317 & 2.199 & C & -1.330 & -0.061 & 2.108 \\
\hline & & & & $\mathrm{H}$ & -1.216 & -1.382 & 2.454 & $\mathrm{H}$ & -1.531 & -0.981 & 2.666 \\
\hline & & & & $\mathrm{H}$ & -1.126 & 0.270 & 3.123 & $\mathrm{H}$ & -1.297 & 0.788 & 2.798 \\
\hline & & & & $\mathrm{H}$ & -2.024 & -0.041 & 1.615 & $\mathrm{H}$ & -2.138 & 0.090 & 1.391 \\
\hline & & & & $\mathrm{C}$ & 1.709 & -1.832 & 3.642 & C & 1.753 & -1.789 & 3.823 \\
\hline & & & & $\mathrm{H}$ & 1.883 & -1.083 & 4.430 & $\mathrm{H}$ & 2.385 & -1.030 & 4.286 \\
\hline & & & & $\mathrm{H}$ & 0.688 & -2.210 & 3.733 & $\mathrm{H}$ & 0.740 & -1.741 & 4.223 \\
\hline & & & & $\mathrm{H}$ & 2.406 & -2.660 & 3.782 & $\mathrm{H}$ & 2.186 & -2.777 & 3.982 \\
\hline & & & & $\mathrm{O}$ & 3.938 & -2.423 & 1.927 & $\mathrm{O}$ & 3.774 & -2.675 & 1.996 \\
\hline & & & & $\mathrm{O}$ & -1.027 & 0.013 & -0.666 & $\mathrm{O}$ & -1.026 & 0.039 & -0.779 \\
\hline & & & & & & & & $\mathrm{H}$ & 1.071 & -2.226 & 1.917 \\
\hline
\end{tabular}




\begin{tabular}{|c|c|c|c|}
\hline \multicolumn{4}{|c|}{ 8gss-H ${ }^{+}$N4 } \\
\hline $\mathrm{C}$ & 0.316 & -0.037 & -0.165 \\
\hline $\mathrm{N}$ & 0.271 & -0.534 & 1.139 \\
\hline $\mathrm{C}$ & 1.342 & 0.036 & 1.928 \\
\hline $\mathrm{N}$ & 2.119 & -0.896 & 2.737 \\
\hline $\mathrm{C}$ & 3.292 & -1.289 & 2.216 \\
\hline $\mathrm{N}$ & 3.450 & -0.566 & 0.863 \\
\hline $\mathrm{C}$ & 2.323 & 0.544 & 0.840 \\
\hline $\mathrm{N}$ & 1.568 & 0.592 & -0.334 \\
\hline $\mathrm{H}$ & 2.838 & 1.473 & 1.095 \\
\hline $\mathrm{H}$ & 0.981 & 0.844 & 2.579 \\
\hline $\mathrm{C}$ & 3.443 & -1.566 & -0.266 \\
\hline $\mathrm{H}$ & 2.465 & -2.041 & -0.311 \\
\hline $\mathrm{H}$ & 3.659 & -1.049 & -1.199 \\
\hline $\mathrm{H}$ & 4.216 & -2.303 & -0.046 \\
\hline $\mathrm{C}$ & 1.892 & 1.385 & -1.519 \\
\hline $\mathrm{H}$ & 2.085 & 2.427 & -1.244 \\
\hline $\mathrm{H}$ & 2.758 & 0.982 & -2.053 \\
\hline $\mathrm{H}$ & 1.025 & 1.343 & -2.181 \\
\hline $\mathrm{C}$ & -1.019 & -0.898 & 1.728 \\
\hline $\mathrm{H}$ & -0.928 & -1.813 & 2.317 \\
\hline $\mathrm{H}$ & -1.407 & -0.089 & 2.360 \\
\hline $\mathrm{H}$ & -1.718 & -1.074 & 0.909 \\
\hline $\mathrm{C}$ & 1.667 & -1.402 & 4.040 \\
\hline $\mathrm{H}$ & 1.192 & -0.588 & 4.593 \\
\hline $\mathrm{H}$ & 0.961 & -2.225 & 3.914 \\
\hline $\mathrm{H}$ & 2.537 & -1.759 & 4.592 \\
\hline $\mathrm{O}$ & 4.147 & -2.036 & 2.606 \\
\hline $\mathrm{O}$ & -0.543 & -0.123 & -1.011 \\
\hline $\mathrm{H}$ & 4.376 & -0.128 & 0.888 \\
\hline
\end{tabular}

\begin{tabular}{|c|c|c|c|}
\hline$y$ & & & \\
\hline $\mathrm{O}$ & 0.146 & -0.611 & 0.045 \\
\hline $\mathrm{C}$ & 0.102 & -0.406 & 1.248 \\
\hline $\mathrm{N}$ & 1.185 & -0.261 & 2.091 \\
\hline $\mathrm{C}$ & 2.551 & -0.238 & 1.606 \\
\hline $\mathrm{H}$ & 3.190 & -0.851 & 2.251 \\
\hline $\mathrm{H}$ & 2.957 & 0.780 & 1.565 \\
\hline $\mathrm{H}$ & 2.553 & -0.653 & 0.597 \\
\hline $\mathrm{C}$ & 0.802 & -0.057 & 3.465 \\
\hline $\mathrm{H}$ & 1.352 & -0.753 & 4.117 \\
\hline $\mathrm{N}$ & 0.912 & 1.298 & 3.985 \\
\hline $\mathrm{C}$ & 2.174 & 1.840 & 4.461 \\
\hline $\mathrm{H}$ & 1.952 & 2.745 & 5.029 \\
\hline $\mathrm{H}$ & 2.834 & 2.096 & 3.628 \\
\hline $\mathrm{H}$ & 2.691 & 1.124 & 5.118 \\
\hline $\mathrm{C}$ & -0.284 & 1.727 & 4.547 \\
\hline $\mathrm{O}$ & -0.444 & 2.722 & 5.233 \\
\hline $\mathrm{N}$ & -1.264 & 0.795 & 4.217 \\
\hline $\mathrm{C}$ & -0.741 & -0.307 & 3.448 \\
\hline $\mathrm{H}$ & -1.034 & -1.263 & 3.908 \\
\hline $\mathrm{N}$ & -1.057 & -0.319 & 2.026 \\
\hline $\mathrm{C}$ & -2.317 & -0.818 & 1.507 \\
\hline $\mathrm{H}$ & -2.596 & -1.737 & 2.048 \\
\hline $\mathrm{H}$ & -2.153 & -1.047 & 0.452 \\
\hline $\mathrm{C}$ & -2.618 & 0.893 & 4.709 \\
\hline $\mathrm{H}$ & -2.906 & -0.084 & 5.129 \\
\hline $\mathrm{H}$ & -2.624 & 1.650 & 5.497 \\
\hline $\mathrm{N}$ & -3.605 & 1.306 & 3.728 \\
\hline $\mathrm{C}$ & -4.195 & 0.382 & 2.768 \\
\hline $\mathrm{H}$ & -4.471 & -0.559 & 3.269 \\
\hline $\mathrm{N}$ & -3.424 & 0.105 & 1.580 \\
\hline $\mathrm{C}$ & -3.931 & 0.750 & 0.455 \\
\hline $\mathrm{O}$ & -3.502 & 0.649 & -0.682 \\
\hline $\mathrm{N}$ & -5.031 & 1.497 & 0.856 \\
\hline $\mathrm{C}$ & -5.424 & 1.178 & 2.221 \\
\hline $\mathrm{H}$ & -6.358 & 0.595 & 2.216 \\
\hline $\mathrm{N}$ & -5.538 & 2.282 & 3.140 \\
\hline $\mathrm{C}$ & -4.475 & 2.362 & 4.018 \\
\hline $\mathrm{O}$ & -4.336 & 3.184 & 4.909 \\
\hline $\mathrm{C}$ & -6.609 & 3.258 & 3.126 \\
\hline $\mathrm{H}$ & -6.571 & 3.809 & 4.068 \\
\hline $\mathrm{H}$ & -7.578 & 2.753 & 3.042 \\
\hline $\mathrm{H}$ & -6.508 & 3.973 & 2.300 \\
\hline $\mathrm{C}$ & -5.989 & 1.969 & -0.130 \\
\hline $\mathrm{H}$ & -6.902 & 1.356 & -0.123 \\
\hline $\mathrm{H}$ & -5.518 & 1.893 & -1.111 \\
\hline $\mathrm{H}$ & -6.261 & 3.012 & 0.053 \\
\hline
\end{tabular}

$\begin{array}{lrrr}\text { 9-H } & \text { N2 } & & \\ \mathrm{O} & -0.028 & -0.283 & -0.022 \\ \mathrm{C} & -0.024 & -0.138 & 1.176 \\ \mathrm{~N} & 1.128 & 0.009 & 1.976 \\ \mathrm{C} & 2.480 & -0.103 & 1.429 \\ \mathrm{H} & 3.037 & -0.894 & 1.942 \\ \mathrm{H} & 3.028 & 0.842 & 1.505 \\ \mathrm{H} & 2.379 & -0.359 & 0.374 \\ \mathrm{C} & 0.802 & 0.094 & 3.337 \\ \mathrm{H} & 1.438 & -0.493 & 4.004 \\ \mathrm{~N} & 0.832 & 1.546 & 3.897 \\ \mathrm{C} & 2.032 & 1.939 & 4.705 \\ \mathrm{H} & 1.860 & 2.941 & 5.099 \\ \mathrm{H} & 2.911 & 1.920 & 4.062 \\ \mathrm{H} & 2.143 & 1.235 & 5.530 \\ \mathrm{C} & -0.490 & 1.717 & 4.706 \\ \mathrm{O} & -0.625 & 2.642 & 5.452 \\ \mathrm{~N} & -1.268 & 0.669 & 4.381 \\ \mathrm{C} & -0.707 & -0.261 & 3.409 \\ \mathrm{H} & -0.878 & -1.285 & 3.768 \\ \mathrm{~N} & -1.131 & -0.097 & 2.033 \\ \mathrm{C} & -2.444 & -0.552 & 1.536 \\ \mathrm{H} & -2.670 & -1.535 & 1.972 \\ \mathrm{H} & -2.330 & -0.647 & 0.454 \\ \mathrm{C} & -2.638 & 0.528 & 4.946 \\ \mathrm{H} & -2.790 & -0.547 & 5.105 \\ \mathrm{H} & -2.647 & 1.053 & 5.904 \\ \mathrm{~N} & -3.656 & 1.097 & 4.130 \\ \mathrm{C} & -4.297 & 0.410 & 3.012 \\ \mathrm{H} & -4.639 & -0.589 & 3.317 \\ \mathrm{~N} & -3.530 & 0.341 & 1.796 \\ \mathrm{C} & -3.931 & 1.310 & 0.861 \\ \mathrm{O} & -3.412 & 1.483 & -0.226 \\ \mathrm{~N} & -5.010 & 1.981 & 1.397 \\ \mathrm{C} & -5.462 & 1.387 & 2.648 \\ \mathrm{H} & -6.428 & 0.884 & 2.505 \\ \mathrm{~N} & -5.531 & 2.275 & 3.788 \\ \mathrm{C} & -4.471 & 2.132 & 4.643 \\ \mathrm{O} & -4.251 & 2.738 & 5.676 \\ \mathrm{C} & -6.600 & 3.236 & 4.023 \\ \mathrm{H} & -6.547 & 3.549 & 5.067 \\ \mathrm{H} & -7.570 & 2.764 & 3.837 \\ \mathrm{H} & -6.501 & 4.120 & 3.386 \\ \mathrm{C} & -5.870 & 2.807 & 0.559 \\ \mathrm{H} & -6.848 & 2.330 & 0.414 \\ \mathrm{H} & -5.382 & 2.920 & -0.409 \\ & -6.016 & 3.797 & 0.999 \\ & 0.756 & 2.179 & 3.091\end{array}$




\begin{tabular}{|c|c|c|c|}
\hline \multicolumn{4}{|c|}{ 9-H ${ }^{+}{ }^{N} 4$} \\
\hline $\mathrm{O}$ & 0.012 & -0.017 & 0.000 \\
\hline $\mathrm{C}$ & 0.008 & -0.011 & 1.210 \\
\hline $\mathrm{N}$ & 1.105 & -0.018 & 2.054 \\
\hline $\mathrm{C}$ & 2.439 & -0.337 & 1.554 \\
\hline $\mathrm{H}$ & 2.794 & -1.284 & 1.978 \\
\hline $\mathrm{H}$ & 3.152 & 0.457 & 1.787 \\
\hline $\mathrm{H}$ & 2.366 & -0.437 & 0.471 \\
\hline $\mathrm{C}$ & 0.717 & -0.158 & 3.432 \\
\hline $\mathrm{H}$ & 1.064 & -1.112 & 3.851 \\
\hline $\mathrm{N}$ & 1.149 & 0.919 & 4.319 \\
\hline $\mathrm{C}$ & 2.551 & 1.120 & 4.702 \\
\hline $\mathrm{H}$ & 2.576 & 1.689 & 5.632 \\
\hline $\mathrm{H}$ & 3.085 & 1.677 & 3.929 \\
\hline $\mathrm{H}$ & 3.022 & 0.147 & 4.855 \\
\hline $\mathrm{C}$ & 0.197 & 1.754 & 4.754 \\
\hline $\mathrm{O}$ & 0.223 & 2.703 & 5.490 \\
\hline $\mathrm{N}$ & -1.148 & 1.235 & 4.215 \\
\hline C & -0.846 & -0.053 & 3.387 \\
\hline $\mathrm{H}$ & -1.353 & -0.856 & 3.930 \\
\hline $\mathrm{N}$ & -1.150 & -0.020 & 2.014 \\
\hline C & -2.491 & -0.151 & 1.416 \\
\hline $\mathrm{H}$ & -3.175 & -0.438 & 2.224 \\
\hline $\mathrm{H}$ & -2.475 & -0.942 & 0.662 \\
\hline C & -2.052 & 2.457 & 3.668 \\
\hline $\mathrm{H}$ & -3.058 & 2.203 & 4.002 \\
\hline $\mathrm{H}$ & -1.633 & 3.284 & 4.245 \\
\hline $\mathrm{N}$ & -2.030 & 2.698 & 2.301 \\
\hline C & -3.076 & 2.332 & 1.362 \\
\hline $\mathrm{H}$ & -4.059 & 2.449 & 1.835 \\
\hline $\mathrm{N}$ & -2.933 & 1.032 & 0.740 \\
\hline C & -2.912 & 1.117 & -0.668 \\
\hline $\mathrm{O}$ & -2.934 & 0.171 & -1.426 \\
\hline $\mathrm{N}$ & -2.926 & 2.459 & -0.992 \\
\hline C & -2.837 & 3.309 & 0.165 \\
\hline $\mathrm{H}$ & -3.569 & 4.124 & 0.103 \\
\hline $\mathrm{N}$ & -1.504 & 3.855 & 0.461 \\
\hline C & -1.055 & 3.538 & 1.704 \\
\hline $\mathrm{O}$ & -0.030 & 3.875 & 2.276 \\
\hline C & -0.785 & 4.757 & -0.428 \\
\hline $\mathrm{H}$ & 0.079 & 5.146 & 0.113 \\
\hline $\mathrm{H}$ & -1.429 & 5.592 & -0.722 \\
\hline $\mathrm{H}$ & -0.439 & 4.231 & -1.322 \\
\hline $\mathrm{C}$ & -3.168 & 2.931 & -2.349 \\
\hline $\mathrm{H}$ & -4.011 & 3.629 & -2.366 \\
\hline $\mathrm{H}$ & -3.408 & 2.061 & -2.961 \\
\hline $\mathrm{H}$ & -2.285 & 3.420 & -2.772 \\
\hline $\mathrm{H}$ & -1.644 & 0.947 & 5.063 \\
\hline
\end{tabular}

\begin{tabular}{|c|c|c|c|}
\hline \multicolumn{4}{|c|}{$9-\mathrm{H}^{+}{ }_{-} \mathrm{N8}$} \\
\hline $\mathrm{O}$ & -0.020 & 0.053 & 0.053 \\
\hline C & 0.006 & 0.029 & 1.267 \\
\hline $\mathrm{N}$ & 1.113 & -0.009 & 2.079 \\
\hline C & 2.467 & -0.075 & 1.544 \\
\hline $\mathrm{H}$ & 3.023 & -0.880 & 2.037 \\
\hline $\mathrm{H}$ & 3.005 & 0.868 & 1.676 \\
\hline $\mathrm{H}$ & 2.394 & -0.290 & 0.477 \\
\hline C & 0.784 & -0.094 & 3.479 \\
\hline $\mathrm{H}$ & 1.338 & -0.916 & 3.952 \\
\hline $\mathrm{N}$ & 0.961 & 1.132 & 4.253 \\
\hline C & 2.265 & 1.685 & 4.600 \\
\hline $\mathrm{H}$ & 2.114 & 2.437 & 5.376 \\
\hline $\mathrm{H}$ & 2.737 & 2.158 & 3.736 \\
\hline $\mathrm{H}$ & 2.920 & 0.896 & 4.986 \\
\hline C & -0.186 & 1.558 & 4.852 \\
\hline $\mathrm{O}$ & -0.357 & 2.503 & 5.600 \\
\hline $\mathrm{N}$ & -1.220 & 0.663 & 4.467 \\
\hline C & -0.770 & -0.303 & 3.477 \\
\hline $\mathrm{H}$ & -1.072 & -1.319 & 3.764 \\
\hline $\mathrm{N}$ & -1.144 & -0.005 & 2.101 \\
\hline C & -2.384 & -0.464 & 1.505 \\
\hline $\mathrm{H}$ & -2.652 & -1.459 & 1.886 \\
\hline $\mathrm{H}$ & -2.224 & -0.513 & 0.425 \\
\hline C & -2.519 & 0.833 & 4.972 \\
\hline $\mathrm{H}$ & -3.010 & -0.108 & 5.237 \\
\hline $\mathrm{H}$ & -2.483 & 1.516 & 5.825 \\
\hline $\mathrm{N}$ & -3.456 & 1.517 & 3.942 \\
\hline C & -4.189 & 0.593 & 2.942 \\
\hline $\mathrm{H}$ & -4.398 & -0.332 & 3.487 \\
\hline $\mathrm{N}$ & -3.522 & 0.422 & 1.721 \\
\hline C & -4.026 & 1.308 & 0.739 \\
\hline $\mathrm{O}$ & -3.626 & 1.401 & -0.395 \\
\hline $\mathrm{N}$ & -5.067 & 2.029 & 1.335 \\
\hline C & -5.447 & 1.421 & 2.593 \\
\hline $\mathrm{H}$ & -6.350 & 0.803 & 2.492 \\
\hline $\mathrm{N}$ & -5.619 & 2.311 & 3.736 \\
\hline C & -4.569 & 2.384 & 4.575 \\
\hline $\mathrm{O}$ & -4.398 & 2.956 & 5.614 \\
\hline C & -6.861 & 3.046 & 4.005 \\
\hline $\mathrm{H}$ & -6.845 & 3.379 & 5.043 \\
\hline $\mathrm{H}$ & -7.715 & 2.382 & 3.848 \\
\hline $\mathrm{H}$ & -6.945 & 3.917 & 3.350 \\
\hline C & -6.036 & 2.728 & 0.489 \\
\hline $\mathrm{H}$ & -6.953 & 2.139 & 0.369 \\
\hline $\mathrm{H}$ & -5.576 & 2.870 & -0.490 \\
\hline $\mathrm{H}$ & -6.279 & 3.706 & 0.910 \\
\hline $\mathrm{H}$ & -2.860 & 2.159 & 3.402 \\
\hline
\end{tabular}

\begin{tabular}{|c|c|c|c|}
\hline \multicolumn{4}{|c|}{ 9-H $\mathrm{H}_{-}{ }^{\mathrm{N}} 10$} \\
\hline $\mathrm{O}$ & 0.054 & 0.295 & 0.005 \\
\hline $\mathrm{C}$ & 0.038 & 0.173 & 1.196 \\
\hline $\mathrm{N}$ & 1.367 & 0.155 & 1.993 \\
\hline $\mathrm{C}$ & 2.005 & 1.522 & 1.958 \\
\hline $\mathrm{H}$ & 2.972 & 1.475 & 2.456 \\
\hline $\mathrm{H}$ & 1.351 & 2.231 & 2.464 \\
\hline $\mathrm{H}$ & 2.124 & 1.794 & 0.909 \\
\hline C & 0.991 & -0.414 & 3.413 \\
\hline $\mathrm{H}$ & 1.245 & -1.476 & 3.370 \\
\hline $\mathrm{N}$ & 1.539 & 0.278 & 4.496 \\
\hline $\mathrm{C}$ & 2.834 & 0.000 & 5.115 \\
\hline $\mathrm{H}$ & 2.887 & 0.592 & 6.029 \\
\hline $\mathrm{H}$ & 3.665 & 0.288 & 4.463 \\
\hline $\mathrm{H}$ & 2.921 & -1.062 & 5.367 \\
\hline $\mathrm{C}$ & 0.600 & 1.160 & 5.070 \\
\hline $\mathrm{O}$ & 0.794 & 1.852 & 6.040 \\
\hline $\mathrm{N}$ & -0.574 & 1.064 & 4.312 \\
\hline $\mathrm{C}$ & -0.529 & -0.124 & 3.481 \\
\hline $\mathrm{H}$ & -1.091 & -0.956 & 3.930 \\
\hline $\mathrm{N}$ & -0.951 & 0.023 & 2.096 \\
\hline $\mathrm{C}$ & -2.380 & 0.056 & 1.679 \\
\hline $\mathrm{H}$ & -2.898 & -0.676 & 2.310 \\
\hline $\mathrm{H}$ & -2.418 & -0.258 & 0.632 \\
\hline $\mathrm{C}$ & -1.829 & 1.612 & 4.861 \\
\hline $\mathrm{H}$ & -2.456 & 0.786 & 5.223 \\
\hline $\mathrm{H}$ & -1.529 & 2.241 & 5.702 \\
\hline $\mathrm{N}$ & -2.586 & 2.411 & 3.947 \\
\hline $\mathrm{C}$ & -3.536 & 1.922 & 2.982 \\
\hline $\mathrm{H}$ & -4.243 & 1.221 & 3.447 \\
\hline $\mathrm{N}$ & -2.968 & 1.350 & 1.764 \\
\hline $\mathrm{C}$ & -3.497 & 1.960 & 0.604 \\
\hline $\mathrm{O}$ & -3.322 & 1.558 & -0.531 \\
\hline $\mathrm{N}$ & -4.246 & 3.032 & 1.016 \\
\hline $\mathrm{C}$ & -4.208 & 3.229 & 2.448 \\
\hline $\mathrm{H}$ & -5.225 & 3.388 & 2.832 \\
\hline $\mathrm{N}$ & -3.313 & 4.274 & 2.929 \\
\hline $\mathrm{C}$ & -2.421 & 3.803 & 3.869 \\
\hline $\mathrm{O}$ & -1.635 & 4.447 & 4.539 \\
\hline C & -3.644 & 5.692 & 2.853 \\
\hline $\mathrm{H}$ & -2.938 & 6.233 & 3.484 \\
\hline $\mathrm{H}$ & -4.663 & 5.874 & 3.220 \\
\hline $\mathrm{H}$ & -3.560 & 6.061 & 1.829 \\
\hline C & -4.968 & 3.885 & 0.082 \\
\hline $\mathrm{H}$ & -5.972 & 4.088 & 0.467 \\
\hline $\mathrm{H}$ & -5.048 & 3.353 & -0.866 \\
\hline $\mathrm{H}$ & -4.450 & 4.833 & -0.091 \\
\hline $\mathrm{H}$ & 1.983 & -0.496 & 1.496 \\
\hline
\end{tabular}




\begin{tabular}{|c|c|c|c|c|c|c|c|}
\hline \multicolumn{8}{|c|}{$10 a$} \\
\hline $\mathrm{N}$ & 0.101 & -0.368 & 0.568 & $\mathrm{~N}$ & -8.536 & 0.217 & -1.760 \\
\hline $\mathrm{C}$ & -0.222 & -0.066 & 1.938 & $\mathrm{~N}$ & -6.027 & -0.631 & -1.530 \\
\hline $\mathrm{H}$ & 0.589 & -0.411 & 2.593 & $\mathrm{C}$ & -7.031 & -1.729 & -1.645 \\
\hline $\mathrm{N}$ & -1.448 & -0.663 & 2.520 & $\mathrm{H}$ & -7.059 & -2.063 & -2.692 \\
\hline $\mathrm{N}$ & -0.640 & 1.823 & 3.427 & $\mathrm{~N}$ & -6.799 & -2.894 & -0.836 \\
\hline $\mathrm{C}$ & -0.215 & 1.510 & 2.080 & $\mathrm{C}$ & -4.754 & -0.806 & -0.870 \\
\hline $\mathrm{H}$ & 0.834 & 1.802 & 1.949 & $\mathrm{H}$ & -4.918 & -1.247 & 0.115 \\
\hline $\mathrm{N}$ & -0.920 & 2.165 & 0.959 & $\mathrm{H}$ & -4.356 & 0.204 & -0.709 \\
\hline $\mathrm{C}$ & -2.348 & 2.464 & 1.029 & $\mathrm{C}$ & -5.748 & -3.886 & -1.088 \\
\hline $\mathrm{H}$ & -2.796 & 1.785 & 1.754 & $\mathrm{H}$ & -6.151 & -4.846 & -0.743 \\
\hline $\mathrm{H}$ & -2.788 & 2.236 & 0.048 & $\mathrm{H}$ & -5.613 & -3.965 & -2.172 \\
\hline C & -0.965 & 3.191 & 3.837 & $\mathrm{~N}$ & -4.443 & -3.735 & -0.460 \\
\hline $\mathrm{H}$ & -0.415 & 3.897 & 3.206 & $\mathrm{C}$ & -3.392 & -2.950 & -1.074 \\
\hline $\mathrm{H}$ & -0.593 & 3.318 & 4.861 & $\mathrm{H}$ & -3.011 & -3.490 & -1.950 \\
\hline $\mathrm{N}$ & -2.379 & 3.554 & 3.844 & $\mathrm{~N}$ & -3.744 & -1.609 & -1.578 \\
\hline C & -3.027 & 4.254 & 2.761 & $\mathrm{~N}$ & -1.142 & -2.120 & -0.701 \\
\hline $\mathrm{H}$ & -2.746 & 5.315 & 2.784 & C & -2.189 & -2.885 & -0.065 \\
\hline $\mathrm{N}$ & -2.734 & 3.829 & 1.371 & $\mathrm{H}$ & -1.858 & -3.923 & 0.062 \\
\hline $\mathrm{N}$ & -5.251 & 4.882 & 1.956 & $\mathrm{~N}$ & -2.642 & -2.470 & 1.283 \\
\hline $\mathrm{C}$ & -4.575 & 4.230 & 3.062 & $\mathrm{C}$ & 0.072 & -1.716 & 0.009 \\
\hline $\mathrm{H}$ & -4.709 & 4.835 & 3.968 & $\mathrm{H}$ & 0.900 & -1.783 & -0.708 \\
\hline $\mathrm{N}$ & -5.030 & 2.880 & 3.437 & $\mathrm{H}$ & 0.278 & -2.439 & 0.806 \\
\hline C & -6.705 & 4.882 & 1.851 & $\mathrm{C}$ & -2.590 & -1.070 & 1.712 \\
\hline $\mathrm{H}$ & -6.968 & 5.760 & 1.248 & $\mathrm{H}$ & -3.496 & -0.872 & 2.298 \\
\hline $\mathrm{H}$ & -7.129 & 5.040 & 2.849 & $\mathrm{H}$ & -2.629 & -0.437 & 0.825 \\
\hline C & -5.393 & 1.951 & 2.354 & $\mathrm{H}$ & -2.984 & 2.815 & 4.195 \\
\hline $\mathrm{H}$ & -5.054 & 2.388 & 1.413 & $\mathrm{H}$ & -5.751 & 2.912 & 4.148 \\
\hline $\mathrm{H}$ & -4.846 & 1.010 & 2.488 & $\mathrm{H}$ & -7.075 & 0.940 & 2.953 \\
\hline $\mathrm{N}$ & -6.777 & 1.581 & 2.226 & $\mathrm{H}$ & -10.166 & 0.222 & 1.667 \\
\hline C & -7.832 & 2.584 & 1.978 & $\mathrm{H}$ & -9.192 & -2.307 & 0.261 \\
\hline $\mathrm{H}$ & -8.240 & 2.954 & 2.933 & $\mathrm{H}$ & -6.971 & -2.743 & 0.150 \\
\hline $\mathrm{N}$ & -7.411 & 3.749 & 1.241 & $\mathrm{H}$ & -4.493 & -3.546 & 0.539 \\
\hline $\mathrm{N}$ & -8.889 & 2.056 & -0.232 & $\mathrm{H}$ & -2.275 & -3.083 & 2.002 \\
\hline $\mathrm{C}$ & -9.033 & 1.875 & 1.232 & $\mathrm{H}$ & -1.231 & -1.350 & 3.232 \\
\hline $\mathrm{H}$ & -9.942 & 2.391 & 1.582 & $\mathrm{H}$ & -1.348 & 1.155 & 3.724 \\
\hline $\mathrm{N}$ & -9.191 & 0.498 & 1.682 & $\mathrm{H}$ & -2.163 & 4.509 & 0.883 \\
\hline $\mathrm{C}$ & -9.526 & 1.135 & -1.185 & $\mathrm{H}$ & -0.390 & 2.941 & 0.580 \\
\hline $\mathrm{H}$ & -10.347 & 0.558 & -0.744 & $\mathrm{H}$ & -7.071 & 3.509 & 0.315 \\
\hline $\mathrm{H}$ & -9.945 & 1.751 & -1.989 & $\mathrm{H}$ & -4.785 & 4.667 & 1.078 \\
\hline $\mathrm{C}$ & -8.367 & -0.596 & 1.135 & $\mathrm{H}$ & -7.627 & 0.625 & -1.553 \\
\hline $\mathrm{H}$ & -7.413 & -0.165 & 0.838 & $\mathrm{H}$ & -9.118 & 3.017 & -0.457 \\
\hline $\mathrm{H}$ & -8.177 & -1.298 & 1.959 & $\mathrm{H}$ & -3.940 & -1.630 & -2.572 \\
\hline $\mathrm{N}$ & -8.985 & -1.340 & 0.043 & $\mathrm{H}$ & -5.907 & -0.165 & -2.424 \\
\hline $\mathrm{C}$ & -8.498 & -1.169 & -1.328 & $\mathrm{H}$ & -1.546 & -1.366 & -1.251 \\
\hline $\mathrm{H}$ & -9.172 & -1.785 & -1.938 & $\mathrm{H}$ & -0.2790 & 0.3412 & -0.0534 \\
\hline
\end{tabular}




\begin{tabular}{|c|c|c|c|c|c|c|c|}
\hline $\mathrm{N}$ & 0.110 & -0.155 & 0.056 & $\mathrm{~N}$ & -6.539 & -0.667 & -4.692 \\
\hline $\mathrm{C}$ & -0.004 & -0.033 & 1.495 & $\mathrm{~N}$ & -4.842 & -2.704 & -4.165 \\
\hline $\mathrm{H}$ & 1.003 & -0.132 & 1.923 & $\mathrm{C}$ & -6.128 & -2.818 & -3.479 \\
\hline $\mathrm{N}$ & -0.784 & -1.120 & 2.124 & $\mathrm{H}$ & -6.559 & -3.832 & -3.578 \\
\hline $\mathrm{N}$ & -1.628 & 1.467 & 2.793 & $\mathrm{~N}$ & -5.993 & -2.620 & -2.046 \\
\hline $\mathrm{C}$ & -0.488 & 1.455 & 1.893 & $\mathrm{C}$ & -3.739 & -3.570 & -3.758 \\
\hline $\mathrm{H}$ & 0.337 & 1.875 & 2.493 & $\mathrm{H}$ & -3.188 & -3.829 & -4.669 \\
\hline $\mathrm{N}$ & -0.712 & 2.258 & 0.683 & $\mathrm{H}$ & -4.094 & -4.513 & -3.314 \\
\hline $\mathrm{C}$ & -1.208 & 3.625 & 0.833 & $\mathrm{C}$ & -5.044 & -1.622 & -1.530 \\
\hline $\mathrm{H}$ & -0.631 & 4.250 & 0.139 & $\mathrm{H}$ & -4.705 & -1.023 & -2.377 \\
\hline $\mathrm{H}$ & -1.048 & 4.026 & 1.843 & $\mathrm{H}$ & -5.561 & -0.940 & -0.846 \\
\hline $\mathrm{C}$ & -3.000 & 1.496 & 2.269 & $\mathrm{~N}$ & -3.895 & -2.111 & -0.802 \\
\hline $\mathrm{H}$ & -3.594 & 0.727 & 2.776 & $\mathrm{C}$ & -2.988 & -3.114 & -1.387 \\
\hline $\mathrm{H}$ & -2.961 & 1.232 & 1.205 & $\mathrm{H}$ & -3.368 & -4.136 & -1.225 \\
\hline $\mathrm{N}$ & -3.671 & 2.765 & 2.540 & $\mathrm{~N}$ & -2.781 & -2.987 & -2.817 \\
\hline $\mathrm{C}$ & -3.628 & 3.864 & 1.538 & $\mathrm{~N}$ & -0.778 & -1.991 & -1.248 \\
\hline $\mathrm{H}$ & -3.396 & 4.780 & 2.098 & $\mathrm{C}$ & -1.615 & -3.043 & -0.632 \\
\hline $\mathrm{N}$ & -2.625 & 3.764 & 0.500 & $\mathrm{H}$ & -1.150 & -4.033 & -0.772 \\
\hline $\mathrm{N}$ & -4.945 & 4.426 & -0.525 & $\mathrm{~N}$ & -1.810 & -2.915 & 0.805 \\
\hline $\mathrm{C}$ & -5.083 & 4.103 & 0.891 & $\mathrm{C}$ & 0.388 & -1.471 & -0.533 \\
\hline $\mathrm{H}$ & -5.534 & 4.934 & 1.460 & $\mathrm{H}$ & 1.194 & -1.365 & -1.269 \\
\hline $\mathrm{N}$ & -5.990 & 2.983 & 1.106 & $\mathrm{H}$ & 0.746 & -2.146 & 0.256 \\
\hline $\mathrm{C}$ & -6.139 & 4.657 & -1.326 & $\mathrm{C}$ & -1.991 & -1.602 & 1.451 \\
\hline $\mathrm{H}$ & -5.910 & 5.484 & -2.008 & $\mathrm{H}$ & -2.765 & -1.712 & 2.220 \\
\hline $\mathrm{H}$ & -7.002 & 4.971 & -0.719 & $\mathrm{H}$ & -2.375 & -0.916 & 0.695 \\
\hline $\mathrm{C}$ & -5.900 & 1.826 & 0.188 & $\mathrm{H}$ & -5.686 & -0.447 & -4.193 \\
\hline $\mathrm{H}$ & -4.995 & 1.957 & -0.410 & $\mathrm{H}$ & -4.942 & -2.624 & -5.170 \\
\hline $\mathrm{H}$ & -5.769 & 0.913 & 0.780 & $\mathrm{H}$ & -6.851 & 2.446 & -4.295 \\
\hline $\mathrm{N}$ & -7.019 & 1.570 & -0.686 & $\mathrm{H}$ & -4.192 & 5.080 & -0.696 \\
\hline $\mathrm{C}$ & -7.533 & 2.562 & -1.654 & $\mathrm{H}$ & 0.101 & 2.210 & 0.080 \\
\hline $\mathrm{H}$ & -8.347 & 3.151 & -1.201 & $\mathrm{H}$ & -0.523 & -2.295 & -2.181 \\
\hline $\mathrm{N}$ & -6.562 & 3.519 & -2.142 & $\mathrm{H}$ & -2.564 & -2.028 & -3.073 \\
\hline $\mathrm{N}$ & -7.110 & 1.556 & -3.885 & $\mathrm{H}$ & -5.751 & 3.044 & -2.530 \\
\hline $\mathrm{C}$ & -8.170 & 1.813 & -2.884 & $\mathrm{H}$ & -2.876 & 3.112 & -0.234 \\
\hline $\mathrm{H}$ & -8.915 & 2.515 & -3.292 & $\mathrm{H}$ & -0.706 & 0.232 & -0.410 \\
\hline $\mathrm{N}$ & -8.936 & 0.645 & -2.474 & $\mathrm{H}$ & -4.652 & 2.579 & 2.735 \\
\hline $\mathrm{C}$ & -7.301 & 0.552 & -4.939 & $\mathrm{H}$ & -7.793 & 1.129 & -0.202 \\
\hline $\mathrm{H}$ & -8.351 & 0.279 & -5.088 & $\mathrm{H}$ & -8.847 & -2.442 & -3.133 \\
\hline $\mathrm{H}$ & -6.940 & 1.003 & -5.872 & $\mathrm{H}$ & -4.143 & -2.397 & 0.139 \\
\hline $\mathrm{C}$ & -8.283 & -0.657 & -2.256 & $\mathrm{H}$ & -1.008 & -0.834 & 3.072 \\
\hline $\mathrm{H}$ & -7.256 & -0.454 & -1.980 & $\mathrm{H}$ & -1.541 & 2.174 & 3.514 \\
\hline $\mathrm{H}$ & -8.765 & -1.138 & -1.397 & $\mathrm{H}$ & -6.947 & 3.286 & 1.236 \\
\hline $\mathrm{N}$ & -8.384 & -1.578 & -3.393 & $\mathrm{H}$ & -9.754 & 0.522 & -3.060 \\
\hline $\mathrm{C}$ & -7.186 & -1.866 & -4.190 & $\mathrm{H}$ & -5.945 & -3.492 & -1.536 \\
\hline $\mathrm{H}$ & -7.563 & -2.451 & -5.046 & $\mathrm{H}$ & -1.103 & -3.429 & 1.319 \\
\hline
\end{tabular}




\begin{tabular}{|c|c|c|c|c|c|c|c|}
\hline \multicolumn{8}{|c|}{$10 c$} \\
\hline $\mathrm{N}$ & -0.065 & 0.085 & -0.009 & $\mathrm{~N}$ & -6.870 & -2.145 & -3.191 \\
\hline $\mathrm{C}$ & -0.016 & 0.012 & 1.443 & $\mathrm{~N}$ & -4.651 & -3.430 & -3.254 \\
\hline $\mathrm{H}$ & 1.056 & 0.039 & 1.711 & $\mathrm{C}$ & -5.616 & -4.163 & -2.418 \\
\hline $\mathrm{N}$ & -0.660 & -1.165 & 2.029 & $\mathrm{H}$ & -5.862 & -5.134 & -2.881 \\
\hline $\mathrm{N}$ & -1.894 & 0.946 & 2.804 & $\mathrm{~N}$ & -5.143 & -4.453 & -1.079 \\
\hline $\mathrm{C}$ & -0.704 & 1.324 & 2.068 & $\mathrm{C}$ & -3.292 & -3.930 & -3.436 \\
\hline $\mathrm{H}$ & -0.004 & 1.740 & 2.814 & $\mathrm{H}$ & -2.986 & -3.596 & -4.436 \\
\hline $\mathrm{N}$ & -0.941 & 2.287 & 0.988 & $\mathrm{H}$ & -3.205 & -5.027 & -3.437 \\
\hline $\mathrm{C}$ & -1.575 & 3.575 & 1.244 & $\mathrm{C}$ & -4.008 & -5.339 & -0.821 \\
\hline $\mathrm{H}$ & -1.123 & 4.281 & 0.537 & $\mathrm{H}$ & -4.267 & -5.998 & 0.018 \\
\hline $\mathrm{H}$ & -1.387 & 3.978 & 2.249 & $\mathrm{H}$ & -3.846 & -5.994 & -1.690 \\
\hline $\mathrm{C}$ & -2.671 & 1.915 & 3.571 & $\mathrm{~N}$ & -2.825 & -4.601 & -0.390 \\
\hline $\mathrm{H}$ & -2.027 & 2.765 & 3.842 & $\mathrm{C}$ & -1.820 & -4.150 & -1.365 \\
\hline $\mathrm{H}$ & -2.971 & 1.442 & 4.515 & $\mathrm{H}$ & -1.314 & -5.016 & -1.823 \\
\hline $\mathrm{N}$ & -3.919 & 2.290 & 2.909 & $\mathrm{~N}$ & -2.363 & -3.367 & -2.457 \\
\hline $\mathrm{C}$ & -3.994 & 3.493 & 2.061 & $\mathrm{~N}$ & -0.601 & -1.969 & -1.232 \\
\hline $\mathrm{H}$ & -3.840 & 4.398 & 2.673 & $\mathrm{C}$ & -0.696 & -3.288 & -0.591 \\
\hline $\mathrm{N}$ & -3.019 & 3.542 & 0.990 & $\mathrm{H}$ & 0.262 & -3.829 & -0.691 \\
\hline $\mathrm{N}$ & -5.373 & 3.437 & -0.032 & $\mathrm{~N}$ & -1.004 & -3.266 & 0.828 \\
\hline $\mathrm{C}$ & -5.475 & 3.585 & 1.431 & $\mathrm{C}$ & 0.431 & -1.010 & -0.837 \\
\hline $\mathrm{H}$ & -5.878 & 4.581 & 1.684 & $\mathrm{H}$ & 0.809 & -0.566 & -1.765 \\
\hline $\mathrm{N}$ & -6.326 & 2.610 & 2.083 & $\mathrm{H}$ & 1.294 & -1.475 & -0.341 \\
\hline C & -6.569 & 3.448 & -0.872 & $\mathrm{C}$ & -0.175 & -2.517 & 1.774 \\
\hline $\mathrm{H}$ & -6.264 & 3.926 & -1.811 & $\mathrm{H}$ & 0.873 & -2.551 & 1.444 \\
\hline $\mathrm{H}$ & -7.397 & 4.052 & -0.471 & $\mathrm{H}$ & -0.217 & -3.051 & 2.731 \\
\hline $\mathrm{C}$ & -7.760 & 2.504 & 1.792 & $\mathrm{H}$ & -4.683 & 2.319 & 3.576 \\
\hline $\mathrm{H}$ & -8.281 & 2.312 & 2.738 & $\mathrm{H}$ & -5.921 & 1.685 & 1.979 \\
\hline $\mathrm{H}$ & -8.133 & 3.470 & 1.422 & $\mathrm{H}$ & -8.787 & 0.768 & 1.299 \\
\hline $\mathrm{N}$ & -8.066 & 1.374 & 0.925 & $\mathrm{H}$ & -7.402 & -0.815 & 0.246 \\
\hline C & -8.216 & 1.540 & -0.523 & $\mathrm{H}$ & -7.124 & -3.872 & -0.384 \\
\hline $\mathrm{H}$ & -9.061 & 2.213 & -0.754 & $\mathrm{H}$ & -5.002 & -3.593 & -0.557 \\
\hline $\mathrm{N}$ & -7.059 & 2.110 & -1.185 & $\mathrm{H}$ & -2.364 & -5.053 & 0.392 \\
\hline $\mathrm{N}$ & -7.793 & -0.025 & -2.410 & $\mathrm{H}$ & -1.967 & -2.965 & 0.956 \\
\hline $\mathrm{C}$ & -8.555 & 0.107 & -1.167 & $\mathrm{H}$ & -0.871 & -0.999 & 3.005 \\
\hline $\mathrm{H}$ & -9.640 & 0.085 & -1.373 & $\mathrm{H}$ & -2.527 & 0.402 & 2.225 \\
\hline $\mathrm{N}$ & -8.316 & -0.934 & -0.182 & $\mathrm{H}$ & -3.199 & 2.791 & 0.329 \\
\hline $\mathrm{C}$ & -7.956 & -1.167 & -3.301 & $\mathrm{H}$ & -0.131 & 2.359 & 0.383 \\
\hline $\mathrm{H}$ & -8.921 & -1.679 & -3.186 & $\mathrm{H}$ & -6.276 & 1.462 & -1.181 \\
\hline $\mathrm{H}$ & -7.933 & -0.772 & -4.324 & $\mathrm{H}$ & -4.694 & 4.110 & -0.372 \\
\hline $\mathrm{C}$ & -8.493 & -2.345 & -0.511 & $\mathrm{H}$ & -6.023 & -1.635 & -2.952 \\
\hline $\mathrm{H}$ & -8.829 & -2.850 & 0.403 & $\mathrm{H}$ & -7.748 & 0.861 & -2.898 \\
\hline $\mathrm{H}$ & -9.311 & -2.445 & -1.239 & $\mathrm{H}$ & -2.746 & -2.491 & -2.115 \\
\hline $\mathrm{N}$ & -7.259 & -3.019 & -0.916 & $\mathrm{H}$ & -5.083 & -3.196 & -4.141 \\
\hline $\mathrm{C}$ & -6.982 & -3.309 & -2.331 & $\mathrm{H}$ & -0.615 & -2.098 & -2.238 \\
\hline $\mathrm{H}$ & -7.789 & -3.933 & -2.755 & $\mathrm{H}$ & -1.005 & 0.319 & -0.315 \\
\hline
\end{tabular}




\begin{tabular}{|c|c|c|c|c|c|c|c|c|c|c|c|}
\hline \multicolumn{12}{|l|}{ 11a } \\
\hline $\mathrm{N}$ & 0.040 & 0.021 & 0.024 & $\mathrm{C}$ & -9.845 & 5.069 & -1.272 & $\mathrm{H}$ & -3.902 & -3.720 & -1.097 \\
\hline $\mathrm{C}$ & 0.008 & -0.001 & 1.479 & $\mathrm{H}$ & -10.423 & 4.778 & -0.386 & $\mathrm{~N}$ & -3.632 & -2.240 & -2.491 \\
\hline $\mathrm{H}$ & 1.047 & 0.006 & 1.857 & $\mathrm{H}$ & -8.960 & 4.445 & -1.299 & $\mathrm{~N}$ & -1.343 & -1.557 & -1.227 \\
\hline $\mathrm{N}$ & -0.560 & -1.233 & 2.028 & $\mathrm{C}$ & -8.641 & 6.115 & -3.939 & $\mathrm{C}$ & -2.049 & -2.721 & -0.659 \\
\hline $\mathrm{N}$ & -2.080 & 1.324 & 2.142 & $\mathrm{H}$ & -8.166 & 6.503 & -4.850 & $\mathrm{H}$ & -1.647 & -3.662 & -1.076 \\
\hline $\mathrm{C}$ & -0.630 & 1.333 & 2.045 & $\mathrm{H}$ & -9.563 & 6.684 & -3.779 & $\mathrm{~N}$ & -1.930 & -2.862 & 0.788 \\
\hline $\mathrm{H}$ & -0.278 & 1.383 & 3.093 & $\mathrm{~N}$ & -8.997 & 4.722 & -4.179 & $\mathrm{C}$ & 0.005 & -1.210 & -0.755 \\
\hline $\mathrm{N}$ & -0.144 & 2.465 & 1.256 & $\mathrm{C}$ & -10.210 & 4.144 & -3.619 & $\mathrm{H}$ & 0.463 & -2.007 & -0.160 \\
\hline $\mathrm{C}$ & -2.907 & 1.772 & 1.016 & $\mathrm{H}$ & -11.025 & 4.244 & -4.358 & $\mathrm{H}$ & 0.630 & -1.062 & -1.645 \\
\hline $\mathrm{H}$ & -2.252 & 1.858 & 0.146 & $\mathrm{~N}$ & -10.706 & 4.865 & -2.445 & $\mathrm{C}$ & -1.910 & -1.672 & 1.652 \\
\hline $\mathrm{H}$ & -3.657 & 1.011 & 0.774 & $\mathrm{~N}$ & -9.431 & 2.195 & -2.153 & $\mathrm{H}$ & -2.470 & -0.891 & 1.151 \\
\hline $\mathrm{C}$ & -0.459 & 3.820 & 1.695 & $\mathrm{C}$ & -10.043 & 2.583 & -3.414 & $\mathrm{H}$ & -2.446 & -1.916 & 2.577 \\
\hline $\mathrm{H}$ & -0.590 & 3.883 & 2.787 & $\mathrm{H}$ & -11.080 & 2.201 & -3.352 & $\mathrm{H}$ & -7.543 & 0.405 & -0.902 \\
\hline $\mathrm{H}$ & 0.403 & 4.446 & 1.435 & $\mathrm{~N}$ & -9.327 & 2.026 & -4.560 & $\mathrm{H}$ & -4.473 & -2.364 & 0.707 \\
\hline $\mathrm{N}$ & -1.644 & 4.432 & 1.088 & $\mathrm{C}$ & -9.206 & 0.578 & -4.687 & $\mathrm{H}$ & -0.409 & -1.276 & 3.030 \\
\hline $\mathrm{C}$ & -2.951 & 4.212 & 1.686 & $\mathrm{H}$ & -9.237 & 0.349 & -5.758 & $\mathrm{H}$ & -4.483 & 2.871 & 1.731 \\
\hline $\mathrm{H}$ & -2.776 & 4.161 & 2.775 & $\mathrm{H}$ & -10.049 & 0.049 & -4.215 & $\mathrm{H}$ & -7.995 & 5.422 & 0.808 \\
\hline $\mathrm{N}$ & -3.638 & 3.013 & 1.189 & $\mathrm{C}$ & -7.975 & 2.050 & -2.046 & $\mathrm{H}$ & -11.628 & 4.533 & -2.188 \\
\hline $\mathrm{N}$ & -5.276 & 5.127 & 1.763 & $\mathrm{H}$ & -7.600 & 2.633 & -1.197 & $\mathrm{H}$ & -6.858 & 6.784 & -3.168 \\
\hline $\mathrm{C}$ & -3.886 & 5.455 & 1.466 & $\mathrm{H}$ & -7.539 & 2.485 & -2.947 & $\mathrm{H}$ & -5.464 & 6.009 & -1.714 \\
\hline $\mathrm{H}$ & -3.586 & 6.200 & 2.224 & $\mathrm{~N}$ & -7.460 & 0.706 & -1.867 & $\mathrm{H}$ & -2.705 & 6.186 & -0.013 \\
\hline $\mathrm{N}$ & -3.692 & 5.985 & 0.110 & $\mathrm{C}$ & -7.918 & -0.381 & -2.741 & $\mathrm{H}$ & -1.665 & 4.235 & 0.091 \\
\hline $\mathrm{C}$ & -6.128 & 4.553 & 0.690 & $\mathrm{H}$ & -8.935 & -0.718 & -2.476 & $\mathrm{H}$ & 0.820 & 2.351 & 0.966 \\
\hline $\mathrm{H}$ & -6.604 & 3.642 & 1.073 & $\mathrm{~N}$ & -7.979 & -0.015 & -4.148 & $\mathrm{H}$ & -0.611 & 0.693 & -0.363 \\
\hline $\mathrm{H}$ & -5.463 & 4.251 & -0.118 & $\mathrm{~N}$ & -5.809 & -1.521 & -3.394 & $\mathrm{H}$ & -1.345 & -1.662 & -2.235 \\
\hline C & -4.504 & 7.130 & -0.298 & $\mathrm{C}$ & -6.988 & -1.628 & -2.525 & $\mathrm{H}$ & -3.424 & -1.249 & -2.578 \\
\hline $\mathrm{H}$ & -3.853 & 7.775 & -0.900 & $H$ & -7.595 & -2.510 & -2.794 & $\mathrm{H}$ & -6.129 & -1.410 & -4.351 \\
\hline $\mathrm{H}$ & -4.853 & 7.733 & 0.557 & $\mathrm{~N}$ & -6.651 & -1.796 & -1.115 & $\mathrm{H}$ & -7.174 & 0.549 & -4.409 \\
\hline $\mathrm{N}$ & -5.675 & 6.798 & -1.109 & $\mathrm{C}$ & -4.799 & -2.574 & -3.306 & $\mathrm{H}$ & -9.567 & 2.487 & -5.430 \\
\hline C & -6.979 & 6.654 & -0.494 & $\mathrm{H}$ & -5.206 & -3.527 & -2.928 & $\mathrm{H}$ & -8.188 & 4.131 & -4.030 \\
\hline $\mathrm{H}$ & -7.072 & 7.482 & 0.227 & $\mathrm{H}$ & -4.451 & -2.758 & -4.330 & $\mathrm{H}$ & -2.419 & 1.658 & 3.034 \\
\hline $\mathrm{N}$ & -7.206 & 5.360 & 0.174 & $\mathrm{C}$ & -5.475 & -1.079 & -0.561 & $\mathrm{H}$ & -5.750 & 5.885 & 2.239 \\
\hline $\mathrm{N}$ & -9.406 & 6.461 & -1.089 & $\mathrm{H}$ & -5.182 & -0.330 & -1.295 & $\mathrm{H}$ & -10.135 & 7.090 & -1.404 \\
\hline C & -8.100 & 6.894 & -1.570 & $\mathrm{H}$ & -5.790 & -0.540 & 0.342 & $\mathrm{H}$ & -9.936 & 1.459 & -1.678 \\
\hline $\mathrm{H}$ & -8.177 & 7.990 & -1.673 & $\mathrm{~N}$ & -4.330 & -1.859 & -0.161 & $\mathrm{H}$ & -6.647 & -2.771 & -0.841 \\
\hline $\mathrm{N}$ & -7.676 & 6.281 & -2.844 & $\mathrm{C}$ & -3.553 & -2.675 & -1.112 & $\mathrm{H}$ & -1.154 & -3.467 & 1.030 \\
\hline
\end{tabular}




\begin{tabular}{|c|c|c|c|c|c|c|c|c|c|c|c|}
\hline $\mathrm{N}$ & -1.023 & 0.450 & 0.172 & C & -9.463 & -0.997 & -1.072 & $\mathrm{~N}$ & -2.099 & -1.343 & -1.169 \\
\hline C & -0.319 & 0.231 & 1.442 & C & -6.260 & -0.440 & -1.773 & $\mathrm{C}$ & -1.083 & -2.411 & -1.021 \\
\hline $\mathrm{H}$ & 0.748 & 0.373 & 1.194 & $\mathrm{H}$ & -5.264 & -0.604 & -1.349 & $\mathrm{H}$ & -0.093 & -2.064 & -1.360 \\
\hline $\mathrm{N}$ & -0.571 & -1.087 & 1.987 & $\mathrm{H}$ & -6.134 & 0.109 & -2.721 & $\mathrm{~N}$ & -0.904 & -2.910 & 0.323 \\
\hline $\mathrm{N}$ & -1.584 & 0.938 & 3.569 & $\mathrm{~N}$ & -6.799 & -1.748 & -2.129 & $\mathrm{C}$ & -2.232 & -0.319 & -0.149 \\
\hline C & -0.618 & 1.338 & 2.536 & C & -7.979 & -1.784 & -2.981 & $\mathrm{H}$ & -3.012 & 0.362 & -0.508 \\
\hline $\mathrm{H}$ & 0.314 & 1.425 & 3.114 & $\mathrm{H}$ & -7.943 & -0.867 & -3.590 & $\mathrm{H}$ & -2.588 & -0.772 & 0.775 \\
\hline $\mathrm{N}$ & -0.829 & 2.596 & 1.825 & $\mathrm{~N}$ & -9.208 & -1.908 & -2.194 & $\mathrm{C}$ & -0.028 & -2.241 & 1.275 \\
\hline C & -2.983 & 0.650 & 3.295 & $\mathrm{~N}$ & -8.277 & -4.218 & -3.342 & $\mathrm{H}$ & 0.246 & -2.982 & 2.034 \\
\hline $\mathrm{H}$ & -3.073 & -0.394 & 2.973 & C & -7.873 & -2.968 & -4.010 & $\mathrm{H}$ & 0.892 & -1.975 & 0.730 \\
\hline $\mathrm{H}$ & -3.503 & 0.743 & 4.266 & $\mathrm{H}$ & -8.583 & -2.778 & -4.832 & $\mathrm{H}$ & -0.456 & -1.114 & 2.994 \\
\hline C & -1.579 & 3.686 & 2.443 & $\mathrm{~N}$ & -6.551 & -2.855 & -4.591 & $\mathrm{H}$ & -3.046 & 3.968 & 1.060 \\
\hline $\mathrm{H}$ & -1.519 & 3.611 & 3.534 & C & -6.144 & -3.480 & -5.818 & $\mathrm{H}$ & -9.050 & 1.468 & 1.294 \\
\hline $\mathrm{H}$ & -1.101 & 4.634 & 2.168 & $\mathrm{H}$ & -5.268 & -2.920 & -6.161 & $\mathrm{H}$ & -5.918 & -6.207 & -2.837 \\
\hline $\mathrm{N}$ & -2.988 & 3.837 & 2.067 & $\mathrm{H}$ & -6.930 & -3.330 & -6.569 & $\mathrm{H}$ & -1.203 & 2.369 & 0.904 \\
\hline C & -3.971 & 2.849 & 2.509 & C & -7.652 & -5.472 & -3.705 & $\mathrm{H}$ & -6.466 & 0.775 & -0.084 \\
\hline $\mathrm{H}$ & -4.118 & 3.004 & 3.588 & $\mathrm{H}$ & -7.922 & -5.708 & -4.742 & $\mathrm{H}$ & -1.974 & -0.910 & -2.079 \\
\hline $\mathrm{N}$ & -3.614 & 1.442 & 2.246 & $\mathrm{H}$ & -8.122 & -6.241 & -3.080 & $\mathrm{H}$ & -0.380 & 0.471 & -0.610 \\
\hline $\mathrm{N}$ & -6.418 & 2.679 & 2.633 & $\mathrm{~N}$ & -6.195 & -5.526 & -3.534 & $\mathrm{H}$ & -1.786 & -3.206 & 0.728 \\
\hline C & -5.320 & 3.157 & 1.801 & C & -5.377 & -5.735 & -4.737 & $\mathrm{H}$ & -2.707 & -6.422 & -2.895 \\
\hline $\mathrm{H}$ & -5.418 & 4.251 & 1.743 & $\mathrm{H}$ & -5.474 & -6.776 & -5.096 & $\mathrm{H}$ & -2.748 & -2.497 & -3.145 \\
\hline $\mathrm{N}$ & -5.275 & 2.573 & 0.438 & $\mathrm{~N}$ & -5.801 & -4.936 & -5.886 & $\mathrm{H}$ & -3.572 & -4.093 & -5.739 \\
\hline C & -7.787 & 2.874 & 2.147 & $\mathrm{~N}$ & -3.387 & -4.228 & -4.751 & $\mathrm{H}$ & -2.060 & -5.164 & -0.734 \\
\hline $\mathrm{H}$ & -7.888 & 3.938 & 1.889 & $\mathrm{C}$ & -3.852 & -5.572 & -4.381 & $\mathrm{H}$ & -1.476 & 1.523 & 4.387 \\
\hline $\mathrm{H}$ & -8.448 & 2.696 & 3.002 & $\mathrm{H}$ & -3.319 & -6.337 & -4.974 & $\mathrm{H}$ & -4.395 & 0.924 & 1.857 \\
\hline $\mathrm{C}$ & -5.867 & 3.317 & -0.679 & $\mathrm{~N}$ & -3.578 & -5.915 & -2.992 & $\mathrm{H}$ & -6.524 & -5.436 & -6.387 \\
\hline $\mathrm{H}$ & -5.571 & 2.772 & -1.585 & $\mathrm{C}$ & -2.005 & -3.883 & -4.426 & $\mathrm{H}$ & -8.312 & -4.092 & -2.337 \\
\hline $\mathrm{H}$ & -5.458 & 4.338 & -0.767 & $\mathrm{H}$ & -1.362 & -4.766 & -4.284 & $\mathrm{H}$ & -5.832 & -2.860 & -3.877 \\
\hline $\mathrm{N}$ & -7.305 & 3.482 & -0.660 & $\mathrm{H}$ & -1.603 & -3.328 & -5.282 & $\mathrm{H}$ & -9.999 & 0.764 & -2.016 \\
\hline $\mathrm{C}$ & -8.243 & 2.421 & -0.335 & $\mathrm{C}$ & -3.718 & -4.893 & -1.922 & $\mathrm{H}$ & -6.915 & -2.332 & -1.306 \\
\hline $\mathrm{H}$ & -9.230 & 2.847 & -0.573 & $\mathrm{H}$ & -4.269 & -4.050 & -2.332 & $\mathrm{H}$ & -10.020 & -2.013 & -2.795 \\
\hline $\mathrm{N}$ & -8.205 & 1.981 & 1.075 & $\mathrm{H}$ & -4.336 & -5.317 & -1.122 & $\mathrm{H}$ & -7.587 & 4.364 & -0.256 \\
\hline $\mathrm{N}$ & -9.408 & 0.450 & -1.252 & $\mathrm{~N}$ & -2.505 & -4.435 & -1.280 & $\mathrm{H}$ & -6.296 & 1.685 & 2.821 \\
\hline $\mathrm{C}$ & -8.101 & 1.168 & -1.254 & $\mathrm{C}$ & -1.495 & -3.591 & -1.965 & $\mathrm{H}$ & -4.326 & 2.304 & 0.189 \\
\hline $\mathrm{H}$ & -7.905 & 1.547 & -2.275 & $\mathrm{H}$ & -0.583 & -4.181 & -2.133 & $\mathrm{H}$ & -8.761 & -1.226 & -0.270 \\
\hline $\mathrm{N}$ & -7.024 & 0.324 & -0.803 & $\mathrm{~N}$ & -1.891 & -3.034 & -3.240 & $\mathrm{H}$ & -10.468 & -1.249 & -0.718 \\
\hline
\end{tabular}




\begin{tabular}{|c|c|c|c|c|c|c|c|c|c|c|c|}
\hline & & & & & & & & & & & \\
\hline $\mathrm{N}$ & -0.120 & -0.064 & -0.200 & $\mathrm{C}$ & -10.354 & -0.041 & -1.023 & $\mathrm{~N}$ & -1.635 & -4.054 & -2.616 \\
\hline $\mathrm{C}$ & -0.095 & 0.120 & 1.239 & $\mathrm{H}$ & -11.126 & 0.553 & -1.536 & $\mathrm{~N}$ & -0.332 & -2.220 & -1.306 \\
\hline $\mathrm{H}$ & 0.968 & 0.112 & 1.534 & $\mathrm{H}$ & -10.879 & -0.683 & -0.305 & $\mathrm{C}$ & -0.611 & -3.369 & -0.432 \\
\hline $\mathrm{N}$ & -0.840 & -0.901 & 1.990 & $\mathrm{C}$ & -9.263 & 1.967 & -3.128 & $\mathrm{H}$ & 0.323 & -3.909 & -0.201 \\
\hline N & -1.537 & 1.485 & 2.771 & $\mathrm{H}$ & -9.026 & 2.687 & -3.922 & $\mathrm{~N}$ & -1.205 & -3.015 & 0.843 \\
\hline C & -0.680 & 1.568 & 1.605 & $\mathrm{H}$ & -10.361 & 1.879 & -3.102 & $\mathrm{C}$ & 0.580 & -1.178 & -0.840 \\
\hline $\mathrm{H}$ & 0.176 & 2.200 & 1.902 & $\mathrm{~N}$ & -8.685 & 0.674 & -3.495 & $\mathrm{H}$ & 1.370 & -1.545 & -0.167 \\
\hline $\mathrm{N}$ & -1.333 & 2.123 & 0.410 & $\mathrm{C}$ & -9.419 & -0.564 & -3.312 & $\mathrm{H}$ & 1.086 & -0.797 & -1.737 \\
\hline C & -1.928 & 2.674 & 3.559 & $\mathrm{H}$ & -10.393 & -0.423 & -3.812 & $\mathrm{C}$ & -0.444 & -2.302 & $1.87 \mathrm{C}$ \\
\hline $\mathrm{H}$ & -1.831 & 2.406 & 4.618 & $\mathrm{~N}$ & -9.619 & -0.944 & -1.906 & $\mathrm{H}$ & -0.662 & -2.761 & 2.842 \\
\hline $\mathrm{H}$ & -1.209 & 3.477 & 3.368 & $\mathrm{~N}$ & -8.672 & -2.956 & -3.260 & $\mathrm{H}$ & 0.633 & -2.447 & 1.689 \\
\hline C & -1.909 & 3.457 & 0.479 & $\mathrm{C}$ & -8.663 & -1.756 & -4.073 & $\mathrm{H}$ & -6.929 & -4.955 & -2.522 \\
\hline $\mathrm{H}$ & -1.360 & 4.147 & 1.142 & $\mathrm{~N}$ & -7.322 & -1.291 & -4.453 & $\mathrm{H}$ & -4.606 & -3.655 & -1.923 \\
\hline $\mathrm{H}$ & -1.843 & 3.874 & -0.534 & $\mathrm{C}$ & -6.451 & -2.187 & -5.197 & $\mathrm{H}$ & -2.725 & -4.536 & 0.466 \\
\hline $\mathrm{N}$ & -3.315 & 3.418 & 0.893 & $\mathrm{H}$ & -5.802 & -1.547 & -5.809 & $\mathrm{H}$ & -2.079 & -2.517 & 0.696 \\
\hline C & -3.690 & 3.922 & 2.220 & $\mathrm{H}$ & -6.985 & -2.853 & -5.895 & $\mathrm{H}$ & -0.877 & -0.618 & 2.96 \\
\hline $\mathrm{H}$ & -3.273 & 4.933 & 2.288 & $\mathrm{C}$ & -8.387 & -4.296 & -3.819 & $\mathrm{H}$ & -2.347 & 0.903 & 2.575 \\
\hline $\mathrm{N}$ & -3.283 & 3.173 & 3.404 & $\mathrm{H}$ & -8.548 & -4.269 & -4.902 & $\mathrm{H}$ & 77 & 2.455 & 3.60 \\
\hline $\mathrm{N}$ & -5.800 & 2.690 & 2.302 & $\mathrm{H}$ & -9.134 & -4.984 & -3.404 & $\mathrm{H}$ & -5.619 & 2.181 & 1.44 \\
\hline C & -5.245 & 4.049 & 2.252 & $\mathrm{~N}$ & -7.096 & -4.892 & -3.524 & $\mathrm{H}$ & -8.667 & 1.358 & 1.69 \\
\hline $\mathrm{H}$ & -5.522 & 4.523 & 3.201 & $\mathrm{C}$ & -5.878 & -4.441 & -4.187 & $\mathrm{H}$ & -8.551 & 0.432 & -0.23 \\
\hline $\mathrm{N}$ & -5.636 & 4.935 & 1.161 & $\mathrm{H}$ & -5.873 & -4.833 & -5.211 & $\mathrm{H}$ & -10.016 & -1.877 & -1.880 \\
\hline $\mathrm{C}$ & -7.222 & 2.502 & 2.603 & $\mathrm{~N}$ & -5.621 & -3.000 & -4.305 & $\mathrm{H}$ & -8.149 & -2.807 & -2.40 \\
\hline $\mathrm{H}$ & -7.620 & 3.429 & 3.047 & $\mathrm{~N}$ & -3.461 & -4.760 & -4.187 & $\mathrm{H}$ & -8.530 & 3.514 & -1.99 \\
\hline $\mathrm{H}$ & -7.327 & 1.718 & 3.365 & $\mathrm{C}$ & -4.667 & -5.073 & -3.431 & $\mathrm{H}$ & -9.255 & -1.995 & -4.973 \\
\hline C & -7.023 & 5.078 & 0.755 & $\mathrm{H}$ & -4.805 & -6.161 & -3.432 & $\mathrm{H}$ & -6.921 & 3.493 & -0.570 \\
\hline $\mathrm{H}$ & -7.058 & 5.979 & 0.130 & $\mathrm{~N}$ & -4.758 & -4.655 & -2.026 & $\mathrm{H}$ & -5.024 & 4.774 & 0.363 \\
\hline $\mathrm{H}$ & -7.650 & 5.276 & 1.631 & $\mathrm{C}$ & -2.137 & -4.996 & -3.640 & $\mathrm{H}$ & -3.629 & 2.461 & 0.75 \\
\hline $\mathrm{N}$ & -7.629 & 3.981 & -0.029 & $\mathrm{H}$ & -2.072 & -6.016 & -3.245 & $\mathrm{H}$ & -0.701 & 2.033 & -0.379 \\
\hline $\mathrm{C}$ & -8.569 & 3.037 & 0.543 & $\mathrm{H}$ & -1.449 & -4.942 & -4.492 & $\mathrm{H}$ & -1.080 & -0.059 & -0.536 \\
\hline $\mathrm{H}$ & -9.310 & 3.643 & 1.092 & $\mathrm{C}$ & -3.912 & -5.308 & -1.023 & $\mathrm{H}$ & -0.046 & -2.571 & -2.21 \\
\hline $\mathrm{N}$ & -7.961 & 2.041 & 1.438 & $\mathrm{H}$ & -4.526 & -5.578 & -0.155 & $\mathrm{H}$ & -2.051 & -3.136 & -2.74 \\
\hline $\mathrm{N}$ & -9.473 & 0.858 & -0.276 & $\mathrm{H}$ & -3.524 & -6.251 & -1.442 & $\mathrm{H}$ & -3.545 & -3.826 & -4.58 \\
\hline $\mathrm{C}$ & -9.356 & 2.262 & -0.620 & $\mathrm{~N}$ & -2.877 & -4.413 & -0.530 & $\mathrm{H}$ & -5.637 & -2.541 & -3.398 \\
\hline $\mathrm{H}$ & -10.384 & 2.663 & -0.642 & $\mathrm{C}$ & -1.572 & -4.392 & -1.207 & $\mathrm{H}$ & -7.406 & -0.390 & -4.912 \\
\hline $\mathrm{N}$ & -8.685 & 2.515 & -1.904 & $\mathrm{H}$ & -1.098 & -5.388 & -1.156 & $\mathrm{H}$ & -7.769 & 0.604 & -3.05 \\
\hline
\end{tabular}




\begin{tabular}{lrrr}
\multicolumn{4}{l}{ HTMA } \\
H & 0.030 & -0.052 & 0.066 \\
$\mathrm{C}$ & 0.029 & -0.050 & 1.162 \\
$\mathrm{~N}$ & 1.425 & -0.019 & 1.644 \\
$\mathrm{C}$ & 2.092 & -1.255 & 1.187 \\
$\mathrm{~N}$ & 1.413 & -2.474 & 1.671 \\
$\mathrm{C}$ & 0.017 & -2.440 & 1.188 \\
$\mathrm{H}$ & -0.487 & 0.854 & 1.505 \\
$\mathrm{~N}$ & -0.709 & -1.236 & 1.644 \\
$\mathrm{C}$ & -0.680 & -1.220 & 3.121 \\
$\mathrm{~N}$ & 0.697 & -1.221 & 3.658 \\
$\mathrm{C}$ & 1.397 & -0.035 & 3.121 \\
$\mathrm{C}$ & 1.385 & -2.425 & 3.148 \\
$\mathrm{H}$ & 0.018 & -2.462 & 0.093 \\
$\mathrm{H}$ & -0.508 & -3.330 & 1.551 \\
$\mathrm{H}$ & 3.126 & -1.256 & 1.549 \\
$\mathrm{H}$ & 2.109 & -1.267 & 0.092 \\
$\mathrm{H}$ & 0.870 & -3.316 & 3.524 \\
$\mathrm{H}$ & 2.413 & -2.435 & 3.524 \\
$\mathrm{H}$ & 0.891 & 0.868 & 3.478 \\
$\mathrm{H}$ & 2.425 & -0.028 & 3.498 \\
$\mathrm{H}$ & -1.200 & -0.325 & 3.478 \\
$\mathrm{H}$ & -1.209 & -2.102 & 3.497
\end{tabular}

\begin{tabular}{lrrr}
\multicolumn{4}{l}{ HTMA-H $^{+}$} \\
$\mathrm{H}$ & 0.048 & -0.018 & 0.044 \\
$\mathrm{C}$ & 0.068 & 0.015 & 1.136 \\
$\mathrm{~N}$ & 1.406 & -0.030 & 1.645 \\
$\mathrm{C}$ & 2.087 & -1.255 & 1.173 \\
$\mathrm{~N}$ & 1.394 & -2.463 & 1.671 \\
$\mathrm{C}$ & 0.056 & -2.505 & 1.163 \\
$\mathrm{H}$ & -0.473 & 0.894 & 1.494 \\
$\mathrm{~N}$ & -0.706 & -1.236 & 1.644 \\
$\mathrm{C}$ & -0.678 & -1.219 & 3.200 \\
$\mathrm{~N}$ & 0.685 & -1.221 & 3.640 \\
$\mathrm{C}$ & 1.385 & -0.025 & 3.123 \\
$\mathrm{C}$ & 1.373 & -2.435 & 3.150 \\
$\mathrm{H}$ & 0.036 & -2.496 & 0.071 \\
$\mathrm{H}$ & -0.494 & -3.371 & 1.541 \\
$\mathrm{H}$ & 3.114 & -1.256 & 1.540 \\
$\mathrm{H}$ & 2.107 & -1.267 & 0.080 \\
$\mathrm{H}$ & 0.864 & -3.326 & 3.528 \\
$\mathrm{H}$ & 2.400 & -2.438 & 3.521 \\
$\mathrm{H}$ & 0.885 & 0.878 & 3.482 \\
$\mathrm{H}$ & 2.412 & -0.025 & 3.494 \\
$\mathrm{H}$ & -1.207 & -0.318 & 3.520 \\
$\mathrm{H}$ & -1.215 & -2.108 & 3.540 \\
$\mathrm{H}$ & -1.671 & -1.235 & 1.297
\end{tabular}

\begin{tabular}{|c|c|c|c|c|c|c|c|}
\hline \multicolumn{4}{|c|}{$12 \mathrm{~s}$} & \multicolumn{4}{|c|}{$12 e$} \\
\hline $\mathrm{H}$ & -0.021 & 0.124 & -0.033 & $\mathrm{H}$ & 0.399 & 0.009 & -0.025 \\
\hline $\mathrm{C}$ & -0.022 & -0.069 & 1.059 & $\mathrm{C}$ & 0.060 & -0.028 & 1.030 \\
\hline $\mathrm{N}$ & 1.311 & -0.089 & 1.631 & $\mathrm{~N}$ & 1.156 & -0.061 & 1.979 \\
\hline C & 2.048 & 1.176 & 1.527 & $\mathrm{C}$ & 2.018 & 1.110 & 1.964 \\
\hline $\mathrm{N}$ & 3.450 & 0.796 & 1.311 & $\mathrm{~N}$ & 3.156 & 0.690 & 2.765 \\
\hline C & 3.557 & -0.636 & 1.597 & $\mathrm{C}$ & 3.420 & -0.699 & 2.364 \\
\hline C & 2.197 & -1.141 & 1.133 & $\mathrm{C}$ & 2.059 & -1.211 & 1.833 \\
\hline $\mathrm{H}$ & 3.694 & -0.844 & 2.675 & $\mathrm{H}$ & 3.795 & -1.276 & 3.217 \\
\hline $\mathrm{H}$ & 4.394 & -1.079 & 1.046 & $\mathrm{H}$ & 4.181 & -0.752 & 1.564 \\
\hline $\mathrm{H}$ & 1.925 & -2.111 & 1.564 & $\mathrm{H}$ & 1.674 & -2.070 & 2.394 \\
\hline $\mathrm{H}$ & 2.176 & -1.228 & 0.030 & $\mathrm{H}$ & 2.158 & -1.518 & 0.776 \\
\hline $\mathrm{H}$ & -0.513 & -1.031 & 1.237 & $\mathrm{H}$ & -0.562 & -0.921 & 1.156 \\
\hline $\mathrm{H}$ & -0.626 & 0.707 & 1.541 & $\mathrm{H}$ & -0.571 & 0.847 & 1.220 \\
\hline C & 4.424 & 1.640 & 1.976 & $\mathrm{C}$ & 4.308 & 1.568 & 2.702 \\
\hline $\mathrm{H}$ & 4.336 & 1.615 & 3.081 & $\mathrm{H}$ & 4.029 & 2.573 & 3.032 \\
\hline $\mathrm{H}$ & 5.435 & 1.317 & 1.706 & $\mathrm{H}$ & 5.088 & 1.200 & 3.376 \\
\hline $\mathrm{H}$ & 4.309 & 2.678 & 1.647 & $\mathrm{H}$ & 4.741 & 1.644 & 1.684 \\
\hline $\mathrm{H}$ & 1.696 & 1.796 & 0.681 & $\mathrm{H}$ & 2.324 & 1.387 & 0.921 \\
\hline $\mathrm{H}$ & 1.913 & 1.764 & 2.453 & $\mathrm{H}$ & 1.516 & 1.977 & 2.412 \\
\hline \multicolumn{4}{|c|}{$12 \mathrm{~s}-\mathrm{H}^{+}$} & \multicolumn{4}{|c|}{$12 \mathrm{e}-\mathrm{H}^{+}$} \\
\hline $\mathrm{H}$ & 0.442 & 0.681 & 0.107 & $\mathrm{H}$ & 0.442 & 0.681 & 0.107 \\
\hline C & 0.199 & 0.363 & 1.123 & $\mathrm{C}$ & 0.199 & 0.363 & 1.123 \\
\hline $\mathrm{N}$ & 1.431 & -0.060 & 1.793 & $\mathrm{~N}$ & 1.431 & -0.060 & 1.793 \\
\hline C & 1.276 & -0.446 & 3.166 & $\mathrm{C}$ & 1.276 & -0.446 & 3.166 \\
\hline $\mathrm{N}$ & 2.686 & -0.914 & 3.525 & $\mathrm{~N}$ & 2.686 & -0.914 & 3.525 \\
\hline C & 3.283 & -1.407 & 2.191 & $\mathrm{C}$ & 3.283 & -1.407 & 2.191 \\
\hline C & 2.153 & -1.175 & 1.182 & $\mathrm{C}$ & 2.153 & -1.175 & 1.182 \\
\hline $\mathrm{H}$ & 3.588 & -2.448 & 2.302 & $\mathrm{H}$ & 3.588 & -2.448 & 2.302 \\
\hline $\mathrm{H}$ & 4.155 & -0.788 & 1.981 & $\mathrm{H}$ & 4.155 & -0.788 & 1.981 \\
\hline $\mathrm{H}$ & 1.525 & -2.077 & 1.073 & $\mathrm{H}$ & 1.525 & -2.077 & 1.073 \\
\hline $\mathrm{H}$ & 2.539 & -0.900 & 0.198 & $\mathrm{H}$ & 2.539 & -0.900 & 0.198 \\
\hline $\mathrm{H}$ & -0.552 & -0.442 & 1.073 & $\mathrm{H}$ & -0.552 & -0.442 & 1.073 \\
\hline $\mathrm{H}$ & -0.230 & 1.218 & 1.652 & $\mathrm{H}$ & -0.230 & 1.218 & 1.652 \\
\hline C & 3.516 & 0.150 & 4.189 & $\mathrm{C}$ & 3.516 & 0.150 & 4.189 \\
\hline $\mathrm{H}$ & 3.071 & 0.392 & 5.155 & $\mathrm{H}$ & 3.071 & 0.392 & 5.155 \\
\hline $\mathrm{H}$ & 4.529 & -0.228 & 4.328 & $\mathrm{H}$ & 4.529 & -0.228 & 4.328 \\
\hline $\mathrm{H}$ & 3.521 & 1.026 & 3.539 & $\mathrm{H}$ & 3.521 & 1.026 & 3.539 \\
\hline $\mathrm{H}$ & 0.978 & 0.382 & 3.812 & $\mathrm{H}$ & 0.978 & 0.382 & 3.812 \\
\hline $\mathrm{H}$ & 0.608 & -1.311 & 3.332 & $\mathrm{H}$ & 0.608 & -1.311 & 3.332 \\
\hline $\mathrm{H}$ & 2.613 & -1.705 & 4.170 & $\mathrm{H}$ & 2.613 & -1.705 & 4.170 \\
\hline
\end{tabular}




\begin{tabular}{|c|c|c|c|}
\hline 13 & & & \\
\hline $\mathrm{C}$ & 0.002 & -0.008 & -0.039 \\
\hline$N$ & 0.045 & -0.012 & 1.324 \\
\hline$C$ & 1.269 & -0.017 & 2.124 \\
\hline $\mathrm{N}$ & 0.733 & -0.006 & 3.485 \\
\hline $\mathrm{C}$ & -0.707 & 0.248 & 3.516 \\
\hline C & -1.153 & -0.236 & 2.134 \\
\hline $\mathrm{H}$ & -0.916 & 1.317 & 3.654 \\
\hline $\mathrm{H}$ & -1.169 & -0.302 & 4.338 \\
\hline & -1.994 & 0.327 & 1.726 \\
\hline & -1.424 & -1.301 & 2.149 \\
\hline & 1.488 & -0.002 & 4.621 \\
\hline $\mathrm{H}$ & 1.878 & -0.911 & 1.951 \\
\hline $\mathrm{H}$ & 1.881 & 0.866 & 1.907 \\
\hline O & -1.035 & -0.097 & -0.684 \\
\hline $\mathrm{O}$ & 1.255 & 0.113 & -0.547 \\
\hline $\mathrm{C}$ & 1.490 & 0.183 & -2.004 \\
\hline C & 0.794 & 1.417 & -2.589 \\
\hline $\mathrm{H}$ & 1.080 & 1.531 & -3.640 \\
\hline $\mathrm{H}$ & -0.291 & 1.326 & -2.529 \\
\hline $\mathrm{H}$ & 1.107 & 2.320 & -2.053 \\
\hline C & 1.029 & -1.117 & -2.672 \\
\hline $\mathrm{H}$ & 1.318 & -1.105 & -3.728 \\
\hline $\mathrm{H}$ & 1.509 & -1.980 & -2.199 \\
\hline $\mathrm{H}$ & -0.054 & -1.234 & -2.605 \\
\hline C & 3.012 & 0.326 & -2.087 \\
\hline $\mathrm{H}$ & 3.507 & -0.533 & -1.624 \\
\hline $\mathrm{H}$ & 3.324 & 0.383 & -3.134 \\
\hline $\mathrm{H}$ & 3.344 & 1.235 & -1.576 \\
\hline $\mathrm{O}$ & 1.019 & 0.113 & 5.746 \\
\hline $\mathrm{O}$ & 2.801 & -0.152 & 4.311 \\
\hline $\mathrm{C}$ & 3.837 & -0.211 & 5.364 \\
\hline C & 3.594 & -1.422 & 6.270 \\
\hline $\mathrm{H}$ & 4.435 & -1.533 & 6.962 \\
\hline $\mathrm{H}$ & 2.677 & -1.306 & 6.849 \\
\hline & 3.525 & -2.337 & 5.673 \\
\hline$C$ & 5.122 & -0.390 & 4.551 \\
\hline $\mathrm{H}$ & 5.984 & -0.448 & 5.224 \\
\hline & 5.082 & -1.310 & 3.960 \\
\hline & 5.270 & 0.454 & 3.870 \\
\hline & 3.866 & 1.107 & 6.145 \\
\hline & 4.000 & 1.952 & 5.462 \\
\hline & 2.946 & 1.250 & 6.712 \\
\hline
\end{tabular}

\begin{tabular}{|c|c|c|c|c|c|c|c|}
\hline \multicolumn{4}{|c|}{$13-\mathbf{H}^{+}$} & \multicolumn{4}{|c|}{14} \\
\hline C & 0.062 & 0.013 & -0.009 & $\mathrm{C}$ & 0.213 & -0.457 & -0.139 \\
\hline $\mathrm{N}$ & 0.048 & 0.012 & 1.513 & $\mathrm{~N}$ & -0.014 & 0.142 & 1.178 \\
\hline C & 1.508 & -0.020 & 2.120 & $\mathrm{C}$ & 1.259 & 0.031 & 1.875 \\
\hline $\mathrm{N}$ & 1.316 & -0.654 & 3.368 & $\mathrm{~N}$ & 1.575 & -1.295 & 2.464 \\
\hline C & 0.392 & -1.767 & 3.147 & $\mathrm{C}$ & 2.656 & -1.866 & 1.659 \\
\hline $\mathrm{C}$ & -0.647 & -1.197 & 2.141 & $\mathrm{~N}$ & 3.349 & -0.711 & 1.082 \\
\hline $\mathrm{H}$ & -0.062 & -2.084 & 4.084 & C & 2.298 & 0.235 & 0.738 \\
\hline $\mathrm{H}$ & 0.928 & -2.611 & 2.704 & $\mathrm{~N}$ & 1.560 & -0.031 & -0.522 \\
\hline $\mathrm{H}$ & -1.553 & -0.837 & 2.629 & $\mathrm{H}$ & 2.716 & 1.248 & 0.708 \\
\hline $\mathrm{H}$ & -0.901 & -1.896 & 1.344 & $\mathrm{H}$ & 1.315 & 0.798 & 2.656 \\
\hline C & 1.291 & 0.169 & 4.526 & $\mathrm{C}$ & 4.309 & -1.019 & 0.034 \\
\hline $\mathrm{H}$ & 2.081 & -0.633 & 1.421 & $\mathrm{H}$ & 3.847 & -1.497 & -0.845 \\
\hline $\mathrm{H}$ & 1.893 & 0.994 & 2.214 & $\mathrm{H}$ & 4.802 & -0.097 & -0.294 \\
\hline $\mathrm{O}$ & 0.355 & -0.997 & -0.585 & $\mathrm{H}$ & 5.081 & -1.685 & 0.435 \\
\hline $\mathrm{O}$ & -0.241 & 1.216 & -0.399 & $\mathrm{C}$ & 1.580 & 1.083 & -1.470 \\
\hline $\mathrm{C}$ & -0.277 & 1.610 & -1.902 & $\mathrm{H}$ & 1.057 & 1.983 & -1.100 \\
\hline $\mathrm{C}$ & -1.339 & 0.753 & -2.581 & $\mathrm{H}$ & 2.617 & 1.353 & -1.692 \\
\hline $\mathrm{H}$ & -1.446 & 1.094 & -3.615 & $\mathrm{H}$ & 1.115 & 0.774 & -2.411 \\
\hline $\mathrm{H}$ & -1.063 & -0.303 & -2.604 & $\mathrm{C}$ & -1.185 & -0.340 & 1.892 \\
\hline $\mathrm{H}$ & -2.310 & 0.868 & -2.091 & $\mathrm{H}$ & -1.139 & -1.419 & 2.115 \\
\hline $\mathrm{C}$ & 1.125 & 1.414 & -2.467 & $\mathrm{H}$ & -1.287 & 0.203 & 2.838 \\
\hline $\mathrm{H}$ & 1.135 & 1.784 & -3.496 & $\mathrm{H}$ & -2.081 & -0.141 & 1.295 \\
\hline $\mathrm{H}$ & 1.862 & 1.990 & -1.901 & $\mathrm{C}$ & 1.863 & -1.254 & 3.897 \\
\hline $\mathrm{H}$ & 1.417 & 0.362 & -2.487 & $\mathrm{H}$ & 2.776 & -0.683 & 4.145 \\
\hline $\mathrm{C}$ & -0.675 & 3.077 & -1.819 & $\mathrm{H}$ & 1.019 & -0.802 & 4.427 \\
\hline $\mathrm{H}$ & 0.067 & 3.658 & -1.264 & $\mathrm{H}$ & 1.978 & -2.274 & 4.279 \\
\hline $\mathrm{H}$ & -0.738 & 3.484 & -2.832 & $\mathrm{H}$ & 3.341 & -2.460 & 2.275 \\
\hline $\mathrm{H}$ & -1.651 & 3.197 & $\begin{array}{l}-2.832 \\
-1.342\end{array}$ & $\mathrm{H}$ & 2.243 & -2.527 & 0.874 \\
\hline $\mathrm{O}$ & 1.669 & 1.325 & -1.342 & $\mathrm{H}$ & 0.155 & -1.561 & -0.099 \\
\hline $\mathrm{O}$ & 0.850 & -0.516 & 4.479 & $\mathrm{H}$ & -0.537 & -0.105 & -0.858 \\
\hline $\mathrm{C}$ & 0.855 & 0.063 & 5.568 & & & & \\
\hline $\mathrm{C}$ & -0.076 & $\begin{array}{l}0.063 \\
1.274\end{array}$ & 6.967 & & & & \\
\hline $\mathrm{H}$ & -0.167 & $\begin{array}{l}1.274 \\
1.611\end{array}$ & 7.011 & & & & \\
\hline $\mathrm{H}$ & 0.308 & $\begin{array}{l}1.611 \\
2.103\end{array}$ & 8.048 & & & & \\
\hline $\mathrm{H}$ & -1.078 & $\begin{array}{l}2.103 \\
1.006\end{array}$ & 6.415 & & & & \\
\hline C & 0.305 & -1.100 & 6.660 & & & & \\
\hline $\mathrm{H}$ & 0.261 & -0.810 & $\begin{array}{l}1.190 \\
8.844\end{array}$ & & & & \\
\hline $\mathrm{H}$ & -0.706 & -1.367 & 7.468 & & & & \\
\hline $\mathrm{H}$ & 0.948 & -1.980 & 7.704 & & & & \\
\hline C & 2.294 & 0.397 & 7.356 & & & & \\
\hline $\mathrm{H}$ & 2.938 & -0.481 & 7.250 & & & & \\
\hline $\mathrm{H}$ & 2.697 & 1.215 & 6.756 & & & & \\
\hline $\mathrm{H}$ & 2.312 & 0.702 & 8.406 & & & & \\
\hline $\mathrm{H}$ & -0.396 & 0.882 & 1.820 & & & & \\
\hline
\end{tabular}




$\begin{array}{lrrr}\text { 14-H } & \text { N2 } & & \\ \mathrm{C} & -0.063 & 0.334 & -0.185 \\ \mathrm{~N} & -0.002 & -0.173 & 1.181 \\ \mathrm{C} & 1.386 & -0.006 & 1.633 \\ \mathrm{~N} & 1.950 & -1.078 & 2.441 \\ \mathrm{C} & 2.105 & -2.204 & 1.559 \\ \mathrm{~N} & 2.803 & -1.564 & 0.376 \\ \mathrm{C} & 2.178 & -0.099 & 0.312 \\ \mathrm{~N} & 1.251 & -0.006 & -0.749 \\ \mathrm{H} & 3.041 & 0.571 & 0.249 \\ \mathrm{H} & 1.552 & 0.952 & 2.150 \\ \mathrm{C} & 4.295 & -1.589 & 0.484 \\ \mathrm{H} & 4.723 & -1.030 & -0.350 \\ \mathrm{H} & 4.576 & -1.129 & 1.431 \\ \mathrm{H} & 4.638 & -2.624 & 0.449 \\ \mathrm{C} & 1.637 & 0.723 & -1.961 \\ \mathrm{H} & 2.568 & 0.317 & -2.365 \\ \mathrm{H} & 0.863 & 0.587 & -2.719 \\ \mathrm{H} & 1.766 & 1.801 & -1.781 \\ \mathrm{C} & -1.032 & 0.405 & 2.048 \\ \mathrm{H} & -1.008 & -0.063 & 3.033 \\ \mathrm{H} & -0.914 & 1.495 & 2.172 \\ \mathrm{H} & -2.016 & 0.211 & 1.615 \\ \mathrm{C} & 1.387 & -1.367 & 3.760 \\ \mathrm{H} & 1.335 & -0.438 & 4.333 \\ \mathrm{H} & 0.387 & -1.820 & 3.718 \\ \mathrm{H} & 2.057 & -2.049 & 4.291 \\ \mathrm{H} & -0.867 & -0.151 & -0.749 \\ \mathrm{H} & -0.226 & 1.431 & -0.219 \\ \mathrm{H} & 2.731 & -2.985 & 1.996 \\ \mathrm{H} & 1.163 & -2.632 & 1.187 \\ \mathrm{H} & 2.500 & -2.016 & -0.492\end{array}$

\begin{tabular}{lrrr} 
14-H & \multicolumn{1}{l}{ N4 } & & \\
$\mathrm{C}$ & -0.002 & 0.053 & 0.014 \\
$\mathrm{~N}$ & 0.102 & 0.082 & 1.485 \\
$\mathrm{C}$ & 1.472 & 0.123 & 1.840 \\
$\mathrm{~N}$ & 1.927 & -1.213 & 2.536 \\
$\mathrm{C}$ & 2.199 & -2.120 & 1.322 \\
$\mathrm{~N}$ & 2.839 & -1.275 & 0.367 \\
$\mathrm{C}$ & 2.288 & 0.102 & 0.509 \\
$\mathrm{~N}$ & 1.296 & 0.537 & -0.439 \\
$\mathrm{H}$ & 3.133 & 0.799 & 0.510 \\
$\mathrm{H}$ & 1.735 & 0.925 & 2.536 \\
$\mathrm{C}$ & 4.305 & -1.372 & 0.297 \\
$\mathrm{H}$ & 4.662 & -0.753 & -0.528 \\
$\mathrm{H}$ & 4.823 & -1.051 & 1.216 \\
$\mathrm{H}$ & 4.589 & -2.404 & 0.077 \\
$\mathrm{C}$ & 1.603 & 0.380 & -1.856 \\
$\mathrm{H}$ & 2.547 & 0.883 & -2.080 \\
$\mathrm{H}$ & 1.682 & -0.674 & -2.163 \\
$\mathrm{H}$ & 0.820 & 0.864 & -2.446 \\
$\mathrm{C}$ & -0.809 & 1.001 & 2.181 \\
$\mathrm{H}$ & -0.658 & 0.928 & 3.261 \\
$\mathrm{H}$ & -0.664 & 2.045 & 1.870 \\
$\mathrm{H}$ & -1.842 & 0.711 & 1.975 \\
$\mathrm{C}$ & 0.987 & -1.767 & 3.554 \\
$\mathrm{H}$ & 0.932 & -1.085 & 4.403 \\
$\mathrm{H}$ & 0.007 & -1.867 & 3.090 \\
$\mathrm{H}$ & 1.357 & -2.739 & 3.885 \\
$\mathrm{H}$ & -0.230 & -0.968 & -0.342 \\
$\mathrm{H}$ & -0.804 & 0.716 & -0.327 \\
$\mathrm{H}$ & 2.808 & -2.973 & 1.625 \\
$\mathrm{H}$ & 1.209 & -2.464 & 1.007 \\
$\mathrm{H}$ & 2.827 & -1.025 & 2.988 \\
& & &
\end{tabular}

\begin{tabular}{|c|c|c|c|}
\hline & 0.000 & -0.001 & 0.000 \\
\hline & 0.000 & 0.000 & 1.471 \\
\hline & 1.423 & 0.000 & 1.841 \\
\hline & 2.068 & -1.324 & 1.939 \\
\hline & 2.844 & -1.515 & 0.715 \\
\hline I & 3.185 & -0.165 & 0.269 \\
\hline & 2.104 & 0.733 & 0.633 \\
\hline $\mathrm{N}$ & 1.033 & 0.961 & -0.379 \\
\hline & 2.518 & 1.705 & 0.918 \\
\hline & 1.554 & 0.535 & 2.78 \\
\hline & 3.892 & 0.028 & -1.004 \\
\hline 5 & 0.606 & 2.388 & -0.43 \\
\hline $\mathrm{H}$ & 0.469 & 2.789 & 0.581 \\
\hline 5 & -0.865 & -0.969 & 2.16 \\
\hline 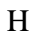 & -0.428 & -1.979 & 2.07 \\
\hline 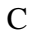 & 2.773 & -1.604 & 3.20 \\
\hline 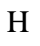 & 2.084 & -1.273 & 3.99 \\
\hline I & 3.749 & -2.100 & 0.90 \\
\hline $\mathrm{H}$ & 2.246 & -2.075 & -0.02 \\
\hline $\mathrm{H}$ & 0.264 & -0.991 & -0.416 \\
\hline $\mathrm{H}$ & -0.974 & 0.269 & -0.40 \\
\hline c & 5.372 & -0.360 & -0.85 \\
\hline I & 5.924 & -0.130 & -1.772 \\
\hline 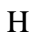 & 5.833 & 0.182 & -0.02 \\
\hline $\mathrm{H}$ & 5.488 & -1.434 & -0.66 \\
\hline 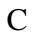 & 1.693 & 3.216 & -1.14 \\
\hline $\mathrm{H}$ & 2.668 & 3.129 & -0.65 \\
\hline 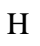 & 1.804 & 2.887 & -2.18 \\
\hline $\mathrm{H}$ & 1.419 & 4.277 & -1.14 \\
\hline 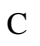 & -0.721 & 2.571 & -1.18 \\
\hline $\mathrm{H}$ & -1.580 & 2.199 & -0.62 \\
\hline 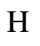 & -0.892 & 3.637 & -1.36 \\
\hline $\mathrm{H}$ & -0.692 & 2.065 & -2.16 \\
\hline $\mathrm{C}$ & -2.268 & -0.999 & 1.53 \\
\hline $\mathrm{H}$ & -2.264 & -1.375 & 0.51 \\
\hline $\mathrm{H}$ & -2.913 & -1.663 & 2.12 \\
\hline $\mathrm{H}$ & -2.719 & 0.001 & 1.54 \\
\hline $\mathrm{C}$ & -0.973 & -0.613 & 3.65 \\
\hline $\mathrm{H}$ & -1.610 & -1.339 & 4.16 \\
\hline $\mathrm{H}$ & -0.001 & -0.618 & 4.15 \\
\hline $\mathrm{H}$ & -1.412 & 0.384 & 3.77 \\
\hline C & 4.100 & -0.844 & 3.40 \\
\hline $\mathrm{H}$ & 4.508 & -1.054 & 4.40 \\
\hline $\mathrm{H}$ & 4.851 & -1.141 & 2.67 \\
\hline $\mathrm{H}$ & 3.960 & 0.238 & 3.32 \\
\hline C & 2.962 & -3.116 & 3.39 \\
\hline $\mathrm{H}$ & 3.656 & -3.529 & 2.65 \\
\hline $\mathrm{H}$ & 3.376 & -3.334 & 4.38 \\
\hline $\mathrm{H}$ & 2.006 & -3.638 & 3.28 \\
\hline $\mathrm{H}$ & 3.852 & 1.106 & -1.19 \\
\hline C & 3.254 & -0.680 & -2.21 \\
\hline $\mathrm{H}$ & 2.203 & -0.399 & -2.31 \\
\hline $\mathrm{H}$ & 3.779 & -0.395 & -3.13 \\
\hline $\mathrm{H}$ & 3.323 & -1.771 & -2.12 \\
\hline
\end{tabular}




\begin{tabular}{|c|c|c|c|}
\hline \multicolumn{4}{|c|}{$15-\mathrm{H}^{+} \_\mathrm{N} 2$} \\
\hline $\mathrm{C}$ & -0.036 & 0.112 & -0.174 \\
\hline $\mathrm{N}$ & -0.009 & -0.049 & 1.276 \\
\hline $\mathrm{C}$ & 1.381 & 0.032 & 1.748 \\
\hline $\mathrm{N}$ & 1.952 & -1.132 & 2.408 \\
\hline $\mathrm{C}$ & 2.109 & -2.156 & 1.412 \\
\hline $\mathrm{N}$ & 2.727 & -1.409 & 0.253 \\
\hline $\mathrm{C}$ & 2.194 & 0.170 & 0.452 \\
\hline $\mathrm{N}$ & 1.311 & 0.604 & -0.524 \\
\hline $\mathrm{H}$ & 3.124 & 0.728 & 0.520 \\
\hline $\mathrm{H}$ & 1.531 & 0.897 & 2.405 \\
\hline $\mathrm{C}$ & 4.230 & -1.567 & 0.047 \\
\hline $\mathrm{H}$ & 4.467 & -0.810 & -0.708 \\
\hline $\mathrm{C}$ & 1.707 & 0.780 & -1.938 \\
\hline $\mathrm{H}$ & 1.921 & -0.211 & -2.384 \\
\hline $\mathrm{C}$ & -1.014 & 0.718 & 2.059 \\
\hline $\mathrm{H}$ & -0.781 & 0.493 & 3.106 \\
\hline $\mathrm{C}$ & 1.485 & -1.525 & 3.759 \\
\hline $\mathrm{H}$ & 1.237 & -0.576 & 4.249 \\
\hline $\mathrm{H}$ & -0.255 & -0.845 & -0.685 \\
\hline $\mathrm{H}$ & -0.794 & 0.831 & -0.493 \\
\hline $\mathrm{H}$ & 2.763 & -2.961 & 1.750 \\
\hline $\mathrm{H}$ & 1.166 & -2.589 & 1.043 \\
\hline $\mathrm{C}$ & 0.560 & 1.405 & -2.742 \\
\hline $\mathrm{H}$ & 0.883 & 1.554 & -3.775 \\
\hline $\mathrm{H}$ & -0.329 & 0.769 & -2.769 \\
\hline $\mathrm{H}$ & 0.284 & 2.380 & -2.328 \\
\hline $\mathrm{C}$ & 2.966 & 1.648 & -2.048 \\
\hline $\mathrm{H}$ & 3.841 & 1.208 & -1.560 \\
\hline $\mathrm{H}$ & 3.226 & 1.783 & -3.102 \\
\hline $\mathrm{H}$ & 2.790 & 2.636 & -1.611 \\
\hline $\mathrm{C}$ & 5.030 & -1.274 & 1.314 \\
\hline $\mathrm{H}$ & 4.852 & -2.019 & 2.093 \\
\hline $\mathrm{H}$ & 6.093 & -1.307 & 1.060 \\
\hline $\mathrm{H}$ & 4.815 & -0.289 & 1.732 \\
\hline $\mathrm{C}$ & 4.524 & -2.950 & -0.539 \\
\hline $\mathrm{H}$ & 5.587 & -3.016 & -0.789 \\
\hline $\mathrm{H}$ & 4.305 & -3.753 & 0.172 \\
\hline $\mathrm{H}$ & 3.960 & -3.135 & -1.460 \\
\hline $\mathrm{C}$ & 2.632 & -2.167 & 4.551 \\
\hline $\mathrm{H}$ & 3.504 & -1.509 & 4.585 \\
\hline $\mathrm{H}$ & 2.312 & -2.368 & 5.577 \\
\hline $\mathrm{H}$ & 2.936 & -3.128 & 4.119 \\
\hline C & 0.231 & -2.417 & 3.766 \\
\hline $\mathrm{H}$ & -0.126 & -2.547 & 4.792 \\
\hline $\mathrm{H}$ & -0.578 & -1.987 & 3.172 \\
\hline $\mathrm{H}$ & 0.449 & -3.417 & 3.373 \\
\hline C & -0.932 & 2.244 & 1.875 \\
\hline $\mathrm{H}$ & -1.201 & 2.549 & 0.858 \\
\hline $\mathrm{H}$ & -1.630 & 2.740 & 2.556 \\
\hline $\mathrm{H}$ & 0.069 & 2.633 & 2.091 \\
\hline $\mathrm{C}$ & -2.425 & 0.189 & 1.780 \\
\hline $\mathrm{H}$ & -3.149 & 0.673 & 2.442 \\
\hline $\mathrm{H}$ & -2.739 & 0.396 & 0.751 \\
\hline $\mathrm{H}$ & -2.479 & -0.892 & 1.941 \\
\hline $\mathrm{H}$ & 2.286 & -1.731 & -0.611 \\
\hline
\end{tabular}

\begin{tabular}{|c|c|c|c|}
\hline \multicolumn{4}{|c|}{$15-\mathrm{H}^{+}{ }_{-} \mathrm{N} 4$} \\
\hline C & -0.029 & 0.048 & 0.098 \\
\hline $\mathrm{N}$ & 0.127 & 0.143 & 1.557 \\
\hline C & 1.510 & 0.124 & 1.846 \\
\hline $\mathrm{N}$ & 1.988 & -1.250 & 2.451 \\
\hline C & 2.306 & -2.070 & 1.189 \\
\hline $\mathrm{N}$ & 2.931 & -1.141 & 0.303 \\
\hline C & 2.286 & 0.182 & 0.488 \\
\hline $\mathrm{N}$ & 1.233 & 0.561 & -0.437 \\
\hline $\mathrm{H}$ & 3.074 & 0.940 & 0.491 \\
\hline $\mathrm{H}$ & 1.813 & 0.876 & 2.578 \\
\hline C & 4.415 & -1.176 & 0.189 \\
\hline $\mathrm{H}$ & 4.658 & -0.324 & -0.453 \\
\hline C & 1.493 & 0.397 & -1.883 \\
\hline $\mathrm{H}$ & 1.757 & -0.655 & -2.086 \\
\hline C & -0.717 & 1.131 & 2.291 \\
\hline $\mathrm{H}$ & -0.374 & 1.074 & 3.332 \\
\hline C & 1.119 & -1.869 & 3.552 \\
\hline $\mathrm{H}$ & 0.615 & -1.015 & 4.012 \\
\hline $\mathrm{H}$ & -0.231 & -0.998 & -0.202 \\
\hline $\mathrm{H}$ & -0.873 & 0.652 & -0.237 \\
\hline $\mathrm{H}$ & 2.939 & -2.920 & 1.445 \\
\hline $\mathrm{H}$ & 1.345 & -2.429 & 0.820 \\
\hline C & 0.243 & 0.749 & -2.700 \\
\hline $\mathrm{H}$ & 0.475 & 0.673 & -3.766 \\
\hline $\mathrm{H}$ & -0.593 & 0.071 & -2.505 \\
\hline $\mathrm{H}$ & -0.081 & 1.775 & -2.498 \\
\hline C & 2.664 & 1.290 & -2.314 \\
\hline $\mathrm{H}$ & 3.598 & 1.046 & -1.800 \\
\hline $\mathrm{H}$ & 2.847 & 1.169 & -3.385 \\
\hline $\mathrm{H}$ & 2.434 & 2.344 & -2.122 \\
\hline C & 5.167 & -0.990 & 1.521 \\
\hline $\mathrm{H}$ & 5.006 & -1.834 & 2.205 \\
\hline $\mathrm{H}$ & 6.246 & -0.939 & 1.344 \\
\hline $\mathrm{H}$ & 4.884 & -0.058 & 2.026 \\
\hline C & 4.864 & -2.445 & -0.543 \\
\hline $\mathrm{H}$ & 5.940 & -2.405 & -0.741 \\
\hline $\mathrm{H}$ & 4.680 & -3.349 & 0.048 \\
\hline $\mathrm{H}$ & 4.340 & -2.546 & -1.497 \\
\hline C & 2.042 & -2.529 & 4.579 \\
\hline $\mathrm{H}$ & 2.758 & -1.819 & 5.009 \\
\hline $\mathrm{H}$ & 1.443 & -2.924 & 5.404 \\
\hline $\mathrm{H}$ & 2.595 & -3.370 & 4.146 \\
\hline C & 0.064 & -2.832 & 3.011 \\
\hline $\mathrm{H}$ & -0.581 & -3.129 & 3.843 \\
\hline $\mathrm{H}$ & -0.563 & -2.362 & 2.252 \\
\hline $\mathrm{H}$ & 0.509 & -3.746 & 2.606 \\
\hline C & -0.533 & 2.577 & 1.807 \\
\hline $\mathrm{H}$ & -0.872 & 2.704 & 0.774 \\
\hline $\mathrm{H}$ & -1.119 & 3.257 & 2.433 \\
\hline $\mathrm{H}$ & 0.513 & 2.895 & 1.856 \\
\hline C & -2.186 & 0.699 & 2.270 \\
\hline $\mathrm{H}$ & -2.783 & 1.371 & 2.893 \\
\hline $\mathrm{H}$ & -2.606 & 0.736 & 1.259 \\
\hline $\mathrm{H}$ & -2.306 & -0.320 & 2.651 \\
\hline $\mathrm{H}$ & 2.896 & -1.050 & 2.879 \\
\hline
\end{tabular}

\begin{tabular}{|c|c|c|c|}
\hline C & 0.065 & -0.044 & -0.006 \\
\hline v & 0.059 & -0.055 & 1.449 \\
\hline & 1.428 & 0.027 & 1.930 \\
\hline $\mathrm{V}$ & 2.129 & -1.260 & 2.002 \\
\hline $\mathrm{C}$ & 3.118 & -1.396 & 0.926 \\
\hline & 3.391 & -0.011 & 0.570 \\
\hline & 2.198 & 0.786 & 0.795 \\
\hline N & 1.238 & 0.784 & -0.316 \\
\hline $\mathrm{H}$ & 2.461 & 1.812 & 1.047 \\
\hline $\mathrm{H}$ & 1.468 & 0.521 & 2.899 \\
\hline C & 4.707 & 0.421 & 0.455 \\
\hline C & 1.324 & 1.714 & -1.326 \\
\hline C & -1.110 & 0.260 & 2.134 \\
\hline $\mathrm{C}$ & 2.039 & -2.053 & 3.122 \\
\hline $\mathrm{H}$ & 0.178 & -1.059 & -0.411 \\
\hline $\mathrm{H}$ & -0.868 & 0.384 & -0.368 \\
\hline $\mathrm{H}$ & 4.041 & -1.874 & 1.251 \\
\hline $\mathrm{H}$ & 2.706 & -1.954 & 0.073 \\
\hline C & 0.219 & 1.707 & -2.366 \\
\hline $\mathrm{H}$ & 0.537 & 2.336 & -3.197 \\
\hline $\mathrm{H}$ & 0.002 & 0.699 & -2.732 \\
\hline $\mathrm{H}$ & -0.706 & 2.120 & -1.948 \\
\hline $\mathrm{C}$ & 4.953 & 1.909 & 0.347 \\
\hline $\mathrm{H}$ & 4.806 & 2.389 & 1.322 \\
\hline $\mathrm{H}$ & 5.993 & 2.050 & 0.051 \\
\hline $\mathrm{H}$ & 4.281 & 2.384 & -0.373 \\
\hline C & 2.880 & -3.315 & 3.142 \\
\hline $\mathrm{H}$ & 2.546 & -3.928 & 3.978 \\
\hline $\mathrm{H}$ & 2.793 & -3.884 & 2.212 \\
\hline $\mathrm{H}$ & 3.938 & -3.070 & 3.289 \\
\hline C & -1.011 & 0.504 & 3.623 \\
\hline $\mathrm{H}$ & -2.025 & 0.522 & 4.021 \\
\hline $\mathrm{H}$ & -0.415 & -0.263 & 4.124 \\
\hline $\mathrm{H}$ & -0.549 & 1.480 & 3.816 \\
\hline $\mathrm{O}$ & 2.261 & 2.508 & -1.377 \\
\hline $\mathrm{O}$ & 5.618 & -0.401 & 0.449 \\
\hline $\mathrm{O}$ & 1.304 & -1.743 & 4.058 \\
\hline O & -2.171 & 0.330 & 1.523 \\
\hline
\end{tabular}




\begin{tabular}{|c|c|c|c|c|c|c|c|c|c|c|c|}
\hline \multicolumn{4}{|c|}{$16-\mathrm{H}^{+} \_\mathrm{N} 2$} & \multicolumn{4}{|c|}{$16-\mathrm{H}^{+} \_\mathrm{N} 4$} & \multicolumn{4}{|c|}{17} \\
\hline $\mathrm{C}$ & -0.286 & 0.387 & 0.078 & $\mathrm{C}$ & 0.146 & -0.178 & 0.153 & $\mathrm{C}$ & 0.008 & -0.011 & -0.004 \\
\hline $\mathrm{N}$ & -0.100 & 0.187 & 1.505 & $\mathrm{~N}$ & 0.249 & -0.094 & 1.623 & $\mathrm{~N}$ & 0.002 & -0.015 & 1.472 \\
\hline $\mathrm{C}$ & 1.294 & 0.046 & 1.854 & $\mathrm{C}$ & 1.549 & 0.249 & 2.025 & $\mathrm{C}$ & 1.374 & -0.005 & 2.017 \\
\hline $\mathrm{N}$ & 1.886 & -1.304 & 1.749 & $\mathrm{~N}$ & 2.479 & -1.032 & 2.392 & $\mathrm{~N}$ & 1.789 & -1.241 & 2.702 \\
\hline $\mathrm{C}$ & 2.674 & -1.456 & 0.551 & $\mathrm{C}$ & 3.300 & -1.268 & 1.126 & $\mathrm{C}$ & 2.182 & -2.162 & 1.640 \\
\hline $\mathrm{N}$ & 3.192 & -0.056 & 0.307 & $\mathrm{~N}$ & 3.522 & 0.063 & 0.655 & $\mathrm{~N}$ & 2.734 & -1.305 & 0.571 \\
\hline $\mathrm{C}$ & 2.012 & 0.829 & 0.725 & $\mathrm{C}$ & 2.283 & 0.817 & 0.767 & $\mathrm{C}$ & 2.237 & 0.082 & 0.686 \\
\hline $\mathrm{N}$ & 1.042 & 0.891 & -0.342 & $\mathrm{~N}$ & 1.312 & 0.579 & -0.293 & $\mathrm{~N}$ & 1.318 & 0.516 & -0.379 \\
\hline $\mathrm{H}$ & 2.397 & 1.813 & 0.999 & $\mathrm{H}$ & 2.504 & 1.882 & 0.846 & $\mathrm{H}$ & 3.071 & 0.782 & 0.747 \\
\hline $\mathrm{H}$ & 1.479 & 0.421 & 2.861 & $\mathrm{H}$ & 1.589 & 0.873 & 2.915 & $\mathrm{H}$ & 1.513 & 0.842 & 2.690 \\
\hline $\mathrm{C}$ & 4.539 & 0.250 & 1.027 & $\mathrm{C}$ & 4.848 & 0.581 & 0.680 & $\mathrm{H}$ & 2.929 & -2.875 & 1.984 \\
\hline $\mathrm{C}$ & 1.422 & 1.242 & -1.616 & $\mathrm{C}$ & 1.397 & 1.340 & -1.461 & $\mathrm{H}$ & 1.282 & -2.704 & 1.307 \\
\hline $\mathrm{C}$ & -1.204 & 0.402 & 2.353 & $\mathrm{C}$ & -0.948 & 0.036 & 2.383 & $\mathrm{H}$ & -0.082 & -1.028 & -0.418 \\
\hline $\mathrm{C}$ & 2.036 & -2.077 & 2.916 & $\mathrm{C}$ & 1.720 & -2.186 & 3.075 & $\mathrm{H}$ & -0.798 & 0.610 & -0.390 \\
\hline $\mathrm{H}$ & -0.530 & -0.542 & -0.453 & $\mathrm{H}$ & 0.171 & -1.221 & -0.188 & $\mathrm{~S}$ & 1.363 & 2.210 & -0.849 \\
\hline $\mathrm{H}$ & -1.082 & 1.114 & -0.094 & $\mathrm{H}$ & -0.799 & 0.263 & -0.164 & $\mathrm{~S}$ & 3.417 & -2.064 & -0.809 \\
\hline $\mathrm{H}$ & 3.510 & -2.140 & 0.678 & $\mathrm{H}$ & 4.244 & -1.764 & 1.355 & $\mathrm{~S}$ & 2.915 & -1.086 & 4.046 \\
\hline $\mathrm{H}$ & 2.089 & -1.734 & -0.332 & $\mathrm{H}$ & 2.688 & -1.861 & 0.444 & $S$ & -1.451 & -0.420 & 2.289 \\
\hline $\mathrm{C}$ & 0.349 & 1.422 & -2.651 & $\mathrm{C}$ & 0.299 & 1.162 & -2.482 & $\mathrm{O}$ & 3.073 & -2.503 & 4.513 \\
\hline $\mathrm{H}$ & 0.817 & 1.711 & -3.591 & $\mathrm{H}$ & 0.624 & 1.623 & -3.414 & $\mathrm{O}$ & 4.206 & -0.495 & 3.568 \\
\hline $\mathrm{H}$ & -0.213 & 0.492 & -2.801 & $\mathrm{H}$ & 0.063 & 0.108 & -2.659 & $\mathrm{O}$ & 2.209 & -0.204 & 5.018 \\
\hline $\mathrm{H}$ & -0.365 & 2.192 & -2.343 & $\mathrm{H}$ & -0.617 & 1.665 & -2.150 & $\mathrm{O}$ & 4.376 & -1.080 & -1.384 \\
\hline $\mathrm{C}$ & 5.080 & 1.620 & 0.767 & $\mathrm{C}$ & 5.033 & 2.030 & 0.319 & $\mathrm{O}$ & 4.078 & -3.282 & -0.223 \\
\hline $\mathrm{H}$ & 4.721 & 2.306 & 1.545 & $\mathrm{H}$ & 4.773 & 2.672 & 1.170 & $\mathrm{O}$ & 2.322 & -2.452 & -1.757 \\
\hline $\mathrm{H}$ & 6.168 & 1.575 & 0.847 & $\mathrm{H}$ & 6.090 & 2.182 & 0.098 & $\mathrm{O}$ & 2.769 & 2.434 & -1.291 \\
\hline $\mathrm{H}$ & 4.778 & 2.012 & -0.207 & $\mathrm{H}$ & 4.416 & 2.320 & -0.535 & $\mathrm{O}$ & 0.358 & 2.274 & -1.961 \\
\hline C & 2.787 & -3.382 & 2.798 & $\mathrm{C}$ & 1.312 & -3.337 & 2.218 & $\mathrm{O}$ & 0.983 & 3.076 & 0.314 \\
\hline $\mathrm{H}$ & 2.616 & -3.946 & 3.715 & $\mathrm{H}$ & 0.742 & -4.034 & 2.834 & $\mathrm{O}$ & -1.571 & -1.912 & 2.379 \\
\hline $\mathrm{H}$ & 2.456 & -3.976 & 1.941 & $\mathrm{H}$ & 0.698 & -3.003 & 1.376 & $\mathrm{O}$ & -1.372 & 0.247 & 3.618 \\
\hline $\mathrm{H}$ & 3.864 & -3.199 & 2.704 & $\mathrm{H}$ & 2.193 & -3.849 & 1.815 & $\mathrm{O}$ & -2.510 & 0.151 & 1.386 \\
\hline $\mathrm{C}$ & -0.969 & 0.415 & 3.841 & $\mathrm{C}$ & -0.830 & 0.469 & 3.825 & & & & \\
\hline $\mathrm{H}$ & -1.944 & 0.422 & 4.327 & $\mathrm{H}$ & -1.820 & 0.391 & 4.273 & & & & \\
\hline $\mathrm{H}$ & -0.383 & -0.442 & 4.180 & $\mathrm{H}$ & -0.130 & -0.143 & 4.400 & & & & \\
\hline $\mathrm{H}$ & -0.434 & 1.327 & 4.134 & $\mathrm{H}$ & -0.508 & 1.516 & 3.886 & & & & \\
\hline $\mathrm{O}$ & 2.634 & 1.379 & -1.857 & $\mathrm{O}$ & 2.342 & 2.101 & -1.607 & & & & \\
\hline $\mathrm{O}$ & 5.012 & -0.625 & 1.684 & $\mathrm{O}$ & 5.757 & -0.175 & 0.972 & & & & \\
\hline $\mathrm{O}$ & 1.544 & -1.677 & 3.957 & $\mathrm{O}$ & 1.542 & -2.035 & 4.247 & & & & \\
\hline $\mathrm{O}$ & -2.292 & 0.585 & 1.834 & $\mathrm{O}$ & -2.002 & -0.187 & 1.825 & & & & \\
\hline $\mathrm{H}$ & 3.312 & 0.211 & -0.704 & $\mathrm{H}$ & 3.122 & -0.703 & 3.122 & & & & \\
\hline
\end{tabular}




\begin{tabular}{lrrr} 
17-H & \multicolumn{1}{r}{ N2 } & & \\
$\mathrm{C}$ & -0.023 & -0.180 & 0.065 \\
$\mathrm{~N}$ & 0.007 & -0.003 & 1.492 \\
$\mathrm{C}$ & 1.356 & -0.059 & 2.059 \\
$\mathrm{~N}$ & 1.750 & -1.319 & 2.706 \\
$\mathrm{C}$ & 2.184 & -2.201 & 1.639 \\
$\mathrm{~N}$ & 2.823 & -1.287 & 0.651 \\
$\mathrm{C}$ & 2.268 & 0.038 & 0.771 \\
$\mathrm{~N}$ & 1.300 & 0.357 & -0.382 \\
$\mathrm{H}$ & 3.028 & 0.820 & 0.788 \\
$\mathrm{H}$ & 1.494 & 0.762 & 2.763 \\
$\mathrm{H}$ & 2.897 & -2.940 & 1.996 \\
$\mathrm{H}$ & 1.309 & -2.712 & 1.211 \\
$\mathrm{H}$ & -0.064 & -1.229 & -0.276 \\
$\mathrm{H}$ & -0.840 & 0.383 & -0.385 \\
$\mathrm{~S}$ & 1.286 & 2.163 & -0.995 \\
$\mathrm{~S}$ & 3.517 & -1.888 & -0.806 \\
$\mathrm{~S}$ & 2.913 & -1.136 & 4.049 \\
$\mathrm{~S}$ & -1.502 & -0.181 & 2.350 \\
$\mathrm{O}$ & 3.299 & -2.549 & 4.329 \\
$\mathrm{O}$ & 4.042 & -0.289 & 3.557 \\
$\mathrm{O}$ & 2.116 & -0.483 & 5.116 \\
$\mathrm{O}$ & 4.801 & -1.176 & -1.001 \\
$\mathrm{O}$ & 3.625 & -3.347 & -0.559 \\
$\mathrm{O}$ & 2.507 & -1.543 & -1.883 \\
$\mathrm{O}$ & 2.660 & 2.285 & -1.518 \\
$\mathrm{O}$ & 0.217 & 2.080 & -2.017 \\
$\mathrm{O}$ & 0.980 & 2.954 & 0.206 \\
$\mathrm{O}$ & -1.754 & -1.642 & 2.505 \\
$\mathrm{O}$ & -1.285 & 0.552 & 3.617 \\
$\mathrm{O}$ & -2.466 & 0.458 & 1.402 \\
$\mathrm{H}$ & 1.649 & -0.196 & -1.204
\end{tabular}

$\begin{array}{lrrr}\mathbf{1 7}-\mathbf{H}^{+} \mathbf{N} \mathbf{N} & & \\ \mathrm{C} & 0.146 & -0.057 & -0.043 \\ \mathrm{~N} & 0.078 & 0.246 & 1.454 \\ \mathrm{C} & 1.558 & 0.079 & 1.968 \\ \mathrm{~N} & 1.820 & -1.141 & 2.644 \\ \mathrm{C} & 2.283 & -2.121 & 1.658 \\ \mathrm{~N} & 2.810 & -1.315 & 0.540 \\ \mathrm{C} & 2.358 & 0.075 & 0.608 \\ \mathrm{~N} & 1.412 & 0.493 & -0.451 \\ \mathrm{H} & 3.199 & 0.770 & 0.604 \\ \mathrm{H} & 1.739 & 0.940 & 2.607 \\ \mathrm{H} & 3.069 & -2.750 & 2.078 \\ \mathrm{H} & 1.441 & -2.758 & 1.348 \\ \mathrm{H} & 0.146 & -1.140 & -0.177 \\ \mathrm{H} & -0.700 & 0.406 & -0.545 \\ \mathrm{~S} & 1.311 & 2.241 & -0.734 \\ \mathrm{~S} & 3.171 & -2.162 & -0.933 \\ \mathrm{~S} & 2.750 & -1.036 & 4.156 \\ \mathrm{~S} & -1.442 & -0.511 & 2.303 \\ \mathrm{O} & 2.489 & -2.351 & 4.797 \\ \mathrm{O} & 4.179 & -0.840 & 3.778 \\ \mathrm{O} & 2.145 & 0.140 & 4.834 \\ \mathrm{O} & 4.027 & -1.228 & -1.704 \\ \mathrm{O} & 3.870 & -3.380 & -0.423 \\ \mathrm{O} & 1.870 & -2.492 & -1.591 \\ \mathrm{O} & 2.710 & 2.684 & -0.919 \\ \mathrm{O} & 0.435 & 2.350 & -1.929 \\ \mathrm{O} & 0.662 & 2.808 & 0.507 \\ \mathrm{O} & -1.281 & -1.956 & 2.086 \\ \mathrm{O} & -1.336 & -0.006 & 3.679 \\ \mathrm{O} & -2.490 & 0.136 & 1.474 \\ \mathrm{H} & -0.088 & 1.266 & 1.488\end{array}$

$\begin{array}{lrrr}\text { 17-H+_O } & & \\ \mathrm{C} & 0.007 & 0.014 & -0.006 \\ \mathrm{~N} & 0.002 & -0.007 & 1.464 \\ \mathrm{C} & 1.396 & 0.001 & 1.980 \\ \mathrm{~N} & 1.732 & -1.191 & 2.764 \\ \mathrm{C} & 2.043 & -2.224 & 1.790 \\ \mathrm{~N} & 2.683 & -1.507 & 0.651 \\ \mathrm{C} & 2.287 & -0.073 & 0.685 \\ \mathrm{~N} & 1.388 & 0.395 & -0.359 \\ \mathrm{H} & 3.173 & 0.558 & 0.727 \\ \mathrm{H} & 1.587 & 0.900 & 2.570 \\ \mathrm{H} & 2.721 & -2.967 & 2.207 \\ \mathrm{H} & 1.108 & -2.708 & 1.469 \\ \mathrm{H} & -0.197 & -0.988 & -0.402 \\ \mathrm{H} & -0.709 & 0.729 & -0.406 \\ \mathrm{~S} & 1.815 & 1.341 & -1.641 \\ \mathrm{~S} & 2.877 & -2.394 & -0.785 \\ \mathrm{~S} & 2.958 & -0.964 & 4.029 \\ \mathrm{~S} & -1.142 & 1.136 & 2.186 \\ \mathrm{O} & 3.131 & -2.353 & 4.552 \\ \mathrm{O} & 4.192 & -0.416 & 3.387 \\ \mathrm{O} & 2.316 & -0.016 & 4.973 \\ \mathrm{O} & 3.632 & -1.435 & -1.695 \\ \mathrm{O} & 3.690 & -3.574 & -0.404 \\ \mathrm{O} & 1.542 & -2.744 & -1.348 \\ \mathrm{O} & 2.990 & 2.140 & -1.261 \\ \mathrm{O} & 2.252 & 0.337 & -2.813 \\ \mathrm{O} & 0.616 & 2.022 & -2.142 \\ \mathrm{O} & -1.318 & 0.661 & 3.578 \\ \mathrm{O} & -0.534 & 2.497 & 2.081 \\ \mathrm{O} & -2.345 & 0.956 & 1.314 \\ \mathrm{H} & 2.830 & -0.431 & -2.395\end{array}$




\begin{tabular}{|c|c|c|c|c|c|c|c|c|c|c|c|}
\hline \multicolumn{3}{|c|}{18} & \multicolumn{5}{|c|}{19} & \multicolumn{4}{|c|}{$19-\mathrm{H}^{+} \_\mathrm{N} 2$} \\
\hline C & 0.000 & 0.000 & 0.000 & C & -0.109 & 0.466 & -0.160 & C & 0.040 & -0.304 & 0.117 \\
\hline $\mathrm{N}$ & 0.000 & 0.000 & 1.472 & $\mathrm{~N}$ & 0.043 & -0.118 & 1.174 & $\mathrm{~N}$ & 0.119 & 0.052 & 1.536 \\
\hline C & 1.350 & 0.000 & 2.027 & C & 1.197 & 0.352 & 1.923 & C & 1.211 & -0.418 & 2.376 \\
\hline $\mathrm{N}$ & 1.882 & -1.348 & 2.275 & $\mathrm{H}$ & 1.255 & -0.184 & 2.877 & $\mathrm{H}$ & 0.952 & -0.272 & 3.428 \\
\hline C & 2.706 & -1.781 & 1.149 & $\mathrm{H}$ & 1.164 & 1.434 & 2.131 & $\mathrm{H}$ & 2.153 & 0.104 & 2.164 \\
\hline $\mathrm{N}$ & 3.158 & -0.486 & 0.615 & $\mathrm{H}$ & 2.110 & 0.129 & 1.360 & $\mathrm{H}$ & 1.367 & -1.487 & 2.208 \\
\hline C & 2.181 & 0.576 & 0.831 & C & -1.249 & 0.016 & 1.827 & C & -0.787 & 0.997 & 1.872 \\
\hline $\mathrm{N}$ & 1.231 & 0.734 & -0.281 & $\mathrm{H}$ & -1.339 & -0.748 & 2.609 & $\mathrm{H}$ & -1.110 & 1.020 & 2.911 \\
\hline $\mathrm{H}$ & 2.669 & 1.529 & 1.023 & $\mathrm{~N}$ & -1.576 & 1.350 & 2.394 & $\mathrm{~N}$ & -0.212 & 2.699 & 1.743 \\
\hline $\mathrm{H}$ & 1.401 & 0.579 & 2.946 & C & -1.792 & 1.340 & 3.840 & C & -0.456 & 3.461 & 2.993 \\
\hline $\mathrm{H}$ & 3.538 & -2.397 & 1.482 & $\mathrm{H}$ & -1.911 & 2.365 & 4.204 & $\mathrm{H}$ & -0.073 & 4.481 & 2.896 \\
\hline $\mathrm{H}$ & 2.106 & -2.342 & 0.423 & $\mathrm{H}$ & -0.915 & 0.918 & 4.338 & $\mathrm{H}$ & 0.046 & 2.965 & 3.826 \\
\hline $\mathrm{H}$ & 0.051 & -1.014 & -0.413 & $\mathrm{H}$ & -2.679 & 0.755 & 4.145 & $\mathrm{H}$ & -1.532 & 3.489 & 3.173 \\
\hline $\mathrm{H}$ & -0.867 & 0.513 & -0.407 & C & -2.717 & 1.875 & 1.630 & C & -0.975 & 3.196 & 0.557 \\
\hline $\mathrm{N}$ & 3.936 & -0.478 & -0.534 & $\mathrm{~N}$ & -3.361 & 0.687 & 1.067 & $\mathrm{~N}$ & -2.205 & 2.445 & 0.630 \\
\hline $\mathrm{O}$ & 4.397 & -1.566 & -0.872 & C & -2.260 & -0.182 & 0.675 & C & -1.840 & 1.043 & 0.766 \\
\hline $\mathrm{O}$ & 4.109 & 0.608 & -1.072 & $\mathrm{H}$ & -2.634 & -1.212 & 0.583 & $\mathrm{H}$ & -2.746 & 0.488 & 1.058 \\
\hline $\mathrm{N}$ & 2.445 & -1.575 & 3.575 & $\mathrm{~N}$ & -1.490 & 0.189 & -0.516 & $\mathrm{~N}$ & -1.142 & 0.405 & -0.362 \\
\hline $\mathrm{O}$ & 2.114 & -0.807 & 4.463 & C & -1.831 & -0.393 & -1.800 & C & -1.974 & -0.302 & -1.373 \\
\hline $\mathrm{O}$ & 3.161 & -2.560 & 3.677 & $\mathrm{H}$ & -2.410 & -1.316 & -1.639 & $\mathrm{H}$ & -2.906 & -0.640 & -0.895 \\
\hline $\mathrm{N}$ & -1.012 & -0.679 & 2.135 & $\mathrm{H}$ & -0.905 & -0.673 & -2.319 & $\mathrm{H}$ & -1.419 & -1.196 & -1.677 \\
\hline $\mathrm{O}$ & -1.971 & -1.013 & 1.443 & C & -4.449 & 0.892 & 0.121 & C & -3.241 & 2.814 & -0.355 \\
\hline $\mathrm{O}$ & -0.863 & -0.848 & 3.338 & $\mathrm{H}$ & -4.860 & -0.105 & -0.101 & $\mathrm{H}$ & -4.108 & 2.177 & -0.128 \\
\hline $\mathrm{N}$ & 1.053 & 2.070 & -0.773 & $\mathrm{H}$ & -5.228 & 1.457 & 0.650 & $\mathrm{H}$ & -3.525 & 3.848 & -0.130 \\
\hline $\mathrm{O}$ & 1.935 & 2.874 & -0.522 & $\mathrm{~N}$ & -4.140 & 1.571 & -1.122 & $\mathrm{~N}$ & -2.857 & 2.699 & -1.732 \\
\hline $\mathrm{O}$ & 0.056 & 2.254 & -1.454 & C & -3.963 & 0.793 & -2.350 & C & -3.272 & 1.511 & -2.495 \\
\hline & & & & $\mathrm{H}$ & -4.585 & -0.114 & -2.323 & $\mathrm{H}$ & -4.242 & 1.140 & -2.135 \\
\hline & & & & $\mathrm{N}$ & -2.605 & 0.422 & -2.725 & $\mathrm{~N}$ & -2.330 & 0.413 & -2.561 \\
\hline & & & & C & -2.000 & 1.664 & -3.208 & C & -1.281 & 0.825 & -3.498 \\
\hline & & & & $\mathrm{N}$ & -3.066 & 2.319 & -3.978 & $\mathrm{~N}$ & -1.979 & 1.638 & -4.498 \\
\hline & & & & C & -4.357 & 1.790 & -3.464 & C & -3.301 & 2.024 & -3.948 \\
\hline & & & & $\mathrm{H}$ & -4.911 & 1.316 & -4.284 & $\mathrm{H}$ & -4.104 & 1.573 & -4.543 \\
\hline & & & & $\mathrm{N}$ & -5.227 & 2.737 & -2.783 & $\mathrm{~N}$ & -3.561 & 3.445 & -3.792 \\
\hline & & & & C & -4.698 & 2.877 & -1.425 & C & -2.824 & 3.871 & -2.609 \\
\hline & & & & C & -5.485 & 3.989 & -3.475 & C & -3.369 & 4.279 & -4.971 \\
\hline & & & & $\mathrm{H}$ & -6.206 & 4.579 & -2.899 & $\mathrm{H}$ & -3.670 & 5.306 & -4.741 \\
\hline & & & & $\mathrm{H}$ & -5.932 & 3.779 & -4.453 & $\mathrm{H}$ & -4.012 & 3.919 & -5.779 \\
\hline & & & & $\mathrm{H}$ & -4.575 & 4.591 & -3.629 & $\mathrm{H}$ & -2.325 & 4.287 & -5.324 \\
\hline & & & & C & -2.911 & 2.188 & -5.426 & C & -2.026 & 1.043 & -5.834 \\
\hline & & & & $\mathrm{H}$ & -2.868 & 1.138 & -5.767 & $\mathrm{H}$ & -2.534 & 0.062 & -5.854 \\
\hline & & & & $\mathrm{H}$ & -1.996 & 2.696 & -5.747 & $\mathrm{H}$ & -1.011 & 0.918 & -6.221 \\
\hline & & & & $\mathrm{H}$ & -3.750 & 2.678 & -5.929 & $\mathrm{H}$ & -2.552 & 1.716 & -6.515 \\
\hline & & & & $\mathrm{H}$ & -1.679 & 2.313 & -2.376 & $\mathrm{H}$ & -0.496 & 1.417 & -2.995 \\
\hline & & & & $\mathrm{H}$ & -1.128 & 1.450 & -3.837 & $\mathrm{H}$ & -0.811 & -0.056 & -3.951 \\
\hline & & & & $\mathrm{H}$ & 0.590 & -0.003 & -0.868 & $\mathrm{H}$ & -0.047 & -1.399 & 0.026 \\
\hline & & & & $\mathrm{H}$ & 0.103 & 1.555 & -0.149 & $\mathrm{H}$ & 0.953 & 0.004 & -0.418 \\
\hline & & & & $\mathrm{H}$ & -3.929 & 3.676 & -1.373 & $\mathrm{H}$ & -1.782 & 4.155 & -2.857 \\
\hline & & & & $\mathrm{H}$ & -5.502 & 3.144 & -0.723 & $\mathrm{H}$ & -3.311 & 4.738 & -2.141 \\
\hline & & & & $\mathrm{H}$ & -3.414 & 2.420 & 2.278 & $\mathrm{H}$ & -1.164 & 4.271 & 0.633 \\
\hline & & & & $\mathrm{H}$ & -2.363 & 2.560 & 0.842 & $\mathrm{H}$ & -0.382 & 2.985 & -0.343 \\
\hline & & & & & & & & $\mathrm{H}$ & 0.788 & 2.664 & 1.541 \\
\hline
\end{tabular}




\begin{tabular}{|c|c|c|c|}
\hline \multicolumn{4}{|c|}{$19-\mathrm{H}^{+}{ }_{-} \mathrm{N} 4$} \\
\hline C & -0.053 & 0.092 & -0.082 \\
\hline & 0.081 & 0.078 & 1.370 \\
\hline & 1.441 & 0.111 & 1.896 \\
\hline & 1.411 & -0.010 & 2.983 \\
\hline & 1.971 & 1.045 & 1.657 \\
\hline & 2.002 & -0.732 & 1.485 \\
\hline & -0.847 & 1.051 & 1.889 \\
\hline 1 & -1.123 & 0.790 & 2.917 \\
\hline & -0.422 & 2.482 & 1.870 \\
\hline & -0.420 & 3.153 & 3.177 \\
\hline 4 & 0.022 & 4.147 & 3.074 \\
\hline & 0.208 & 2.587 & 3.867 \\
\hline & -1.420 & 3.257 & 3.633 \\
\hline & -1.141 & 3.159 & 0.825 \\
\hline $\mathrm{N}$ & -2.476 & 2.439 & 0.748 \\
\hline 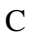 & -2.035 & 0.935 & 0.884 \\
\hline $\mathrm{H}$ & -2.924 & 0.410 & 1.254 \\
\hline & -1.473 & 0.386 & -0.281 \\
\hline $\mathrm{C}$ & -2.275 & -0.344 & -1.275 \\
\hline $\mathrm{H}$ & -3.241 & -0.593 & -0.817 \\
\hline 1 & -1.761 & -1.286 & -1.495 \\
\hline C & -3.442 & 2.834 & -0.424 \\
\hline $\mathrm{H}$ & -4.332 & 2.219 & -0.235 \\
\hline $\mathrm{H}$ & -3.677 & 3.883 & -0.213 \\
\hline N & -2.923 & 2.646 & -1.701 \\
\hline $\mathrm{C}$ & -3.372 & 1.493 & -2.527 \\
\hline $\mathrm{H}$ & -4.397 & 1.226 & -2.243 \\
\hline$N$ & -2.535 & 0.322 & -2.525 \\
\hline $\mathrm{C}$ & -1.407 & 0.608 & -3.423 \\
\hline N & -1.971 & 1.462 & -4.467 \\
\hline $\mathrm{C}$ & -3.240 & 2.032 & -3.970 \\
\hline $\mathrm{H}$ & -4.070 & 1.722 & -4.614 \\
\hline $\mathrm{N}$ & -3.289 & 3.479 & -3.800 \\
\hline C & -2.568 & 3.772 & -2.571 \\
\hline $\mathrm{C}$ & -2.893 & 4.280 & -4.953 \\
\hline $\mathrm{H}$ & -3.040 & 5.340 & -4.724 \\
\hline $\mathrm{H}$ & -3.537 & 4.032 & -5.801 \\
\hline $\mathrm{H}$ & -1.844 & 4.120 & -5.245 \\
\hline 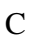 & -2.053 & 0.836 & -5.789 \\
\hline $\mathrm{H}$ & -2.675 & -0.076 & -5.799 \\
\hline 1 & -1.050 & 0.580 & -6.139 \\
\hline 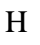 & -2.473 & 1.549 & -6.503 \\
\hline $\mathrm{H}$ & -0.589 & 1.130 & -2.895 \\
\hline $\mathrm{H}$ & -1.007 & -0.325 & -3.837 \\
\hline $\mathrm{H}$ & 0.200 & -0.886 & -0.507 \\
\hline 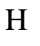 & 0.595 & 0.851 & -0.560 \\
\hline 11 & -1.473 & 3.823 & -2.726 \\
\hline $\mathrm{H}$ & -2.899 & 4.727 & -2.140 \\
\hline $\mathrm{H}$ & -1.294 & 4.220 & 1.035 \\
\hline $\mathrm{H}$ & -0.688 & 3.036 & -0.162 \\
\hline 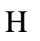 & -2.992 & 2.657 & 1.608 \\
\hline
\end{tabular}

\begin{tabular}{|c|c|c|c|}
\hline \multicolumn{4}{|c|}{$19-\mathrm{H}^{+} \_\mathrm{N} 8$} \\
\hline $\mathrm{C}$ & 0.116 & 0.204 & 0.076 \\
\hline $\mathrm{N}$ & -0.075 & 0.030 & 1.509 \\
\hline $\mathrm{C}$ & 1.150 & -0.119 & 2.288 \\
\hline $\mathrm{H}$ & 0.893 & -0.308 & 3.334 \\
\hline $\mathrm{H}$ & 1.799 & 0.768 & 2.235 \\
\hline $\mathrm{H}$ & 1.706 & -0.987 & 1.921 \\
\hline $\mathrm{C}$ & -0.981 & 1.087 & 1.920 \\
\hline $\mathrm{H}$ & -1.466 & 0.804 & 2.861 \\
\hline $\mathrm{N}$ & -0.418 & 2.453 & 2.039 \\
\hline $\mathrm{C}$ & -0.412 & 3.002 & 3.398 \\
\hline $\mathrm{H}$ & 0.155 & 3.937 & 3.416 \\
\hline $\mathrm{H}$ & 0.094 & 2.304 & 4.068 \\
\hline $\mathrm{H}$ & -1.424 & 3.194 & 3.792 \\
\hline $\mathrm{C}$ & -1.039 & 3.307 & 1.039 \\
\hline $\mathrm{N}$ & -2.271 & 2.588 & 0.651 \\
\hline $\mathrm{C}$ & -1.969 & 1.167 & 0.736 \\
\hline $\mathrm{H}$ & -2.891 & 0.598 & 0.897 \\
\hline $\mathrm{N}$ & -1.212 & 0.613 & -0.422 \\
\hline $\mathrm{C}$ & -1.945 & -0.315 & -1.289 \\
\hline $\mathrm{H}$ & -2.842 & -0.691 & -0.780 \\
\hline $\mathrm{H}$ & -1.320 & -1.177 & -1.534 \\
\hline $\mathrm{C}$ & -3.058 & 3.075 & -0.417 \\
\hline $\mathrm{H}$ & -4.067 & 2.654 & -0.390 \\
\hline $\mathrm{H}$ & -3.125 & 4.163 & -0.373 \\
\hline $\mathrm{N}$ & -2.482 & 2.715 & -1.822 \\
\hline $\mathrm{C}$ & -3.190 & 1.417 & -2.522 \\
\hline $\mathrm{H}$ & -4.130 & 1.294 & -1.983 \\
\hline $\mathrm{N}$ & -2.383 & 0.283 & -2.549 \\
\hline $\mathrm{C}$ & -1.451 & 0.390 & -3.684 \\
\hline $\mathrm{N}$ & -2.048 & 1.409 & -4.558 \\
\hline $\mathrm{C}$ & -3.304 & 1.895 & -3.964 \\
\hline $\mathrm{H}$ & -4.192 & 1.488 & -4.467 \\
\hline $\mathrm{N}$ & -3.467 & 3.335 & -3.832 \\
\hline $\mathrm{C}$ & -2.479 & 3.785 & -2.878 \\
\hline $\mathrm{C}$ & -3.547 & 4.138 & -5.049 \\
\hline $\mathrm{H}$ & -3.822 & 5.164 & -4.785 \\
\hline $\mathrm{H}$ & -4.336 & 3.738 & -5.691 \\
\hline $\mathrm{H}$ & -2.602 & 4.164 & -5.612 \\
\hline $\mathrm{C}$ & -2.109 & 1.032 & -5.972 \\
\hline $\mathrm{H}$ & -2.729 & 0.137 & -6.145 \\
\hline $\mathrm{H}$ & -1.101 & 0.836 & -6.345 \\
\hline $\mathrm{H}$ & -2.517 & 1.858 & -6.558 \\
\hline $\mathrm{H}$ & -0.441 & 0.691 & -3.357 \\
\hline $\mathrm{H}$ & -1.370 & -0.585 & -4.184 \\
\hline $\mathrm{H}$ & 0.447 & -0.729 & -0.391 \\
\hline $\mathrm{H}$ & 0.865 & 0.985 & -0.152 \\
\hline $\mathrm{H}$ & -1.458 & 3.842 & -3.288 \\
\hline $\mathrm{H}$ & -2.754 & 4.754 & -2.452 \\
\hline $\mathrm{H}$ & -1.293 & 4.292 & 1.445 \\
\hline $\mathrm{H}$ & -0.364 & 3.457 & 0.176 \\
\hline $\mathrm{H}$ & -1.529 & 2.382 & -1.626 \\
\hline
\end{tabular}

\begin{tabular}{|c|c|c|c|}
\hline \multicolumn{4}{|c|}{$19-\mathrm{H}^{+} \_\mathrm{N} 10$} \\
\hline C & 0.024 & 0.119 & -0.054 \\
\hline $\mathrm{N}$ & 0.041 & 0.100 & 1.404 \\
\hline C & 1.366 & 0.127 & 2.009 \\
\hline $\mathrm{H}$ & 1.270 & 0.041 & 3.096 \\
\hline $\mathrm{H}$ & 1.927 & 1.045 & 1.773 \\
\hline $\mathrm{H}$ & 1.941 & -0.736 & 1.659 \\
\hline C & -0.899 & 1.116 & 1.841 \\
\hline $\mathrm{H}$ & -1.236 & 0.883 & 2.858 \\
\hline $\mathrm{N}$ & -0.450 & 2.530 & 1.772 \\
\hline C & -0.304 & 3.186 & 3.073 \\
\hline $\mathrm{H}$ & 0.161 & 4.167 & 2.943 \\
\hline $\mathrm{H}$ & 0.363 & 2.594 & 3.706 \\
\hline $\mathrm{H}$ & -1.262 & 3.316 & 3.604 \\
\hline C & -1.317 & 3.238 & 0.832 \\
\hline $\mathrm{N}$ & -2.505 & 2.386 & 0.705 \\
\hline C & -2.029 & 1.018 & 0.798 \\
\hline $\mathrm{H}$ & -2.857 & 0.365 & 1.105 \\
\hline $\mathrm{N}$ & -1.355 & 0.479 & -0.392 \\
\hline C & -2.124 & -0.331 & -1.308 \\
\hline $\mathrm{H}$ & -3.056 & -0.666 & -0.830 \\
\hline $\mathrm{H}$ & -1.559 & -1.230 & -1.583 \\
\hline C & -3.515 & 2.718 & -0.260 \\
\hline $\mathrm{H}$ & -4.381 & 2.070 & -0.083 \\
\hline $\mathrm{H}$ & -3.830 & 3.753 & -0.072 \\
\hline $\mathrm{N}$ & -3.210 & 2.614 & -1.698 \\
\hline C & -3.452 & 1.423 & -2.518 \\
\hline $\mathrm{H}$ & -4.443 & 1.034 & -2.255 \\
\hline $\mathrm{N}$ & -2.514 & 0.316 & -2.562 \\
\hline C & -1.460 & 0.650 & -3.510 \\
\hline $\mathrm{N}$ & -2.156 & 1.444 & -4.540 \\
\hline C & -3.352 & 1.953 & -3.984 \\
\hline $\mathrm{H}$ & -4.241 & 1.788 & -4.600 \\
\hline $\mathrm{N}$ & -3.265 & 3.524 & -3.786 \\
\hline C & -2.566 & 3.639 & -2.435 \\
\hline C & -2.642 & 4.277 & -4.911 \\
\hline $\mathrm{H}$ & -2.542 & 5.325 & -4.621 \\
\hline $\mathrm{H}$ & -3.281 & 4.197 & -5.791 \\
\hline $\mathrm{H}$ & -1.667 & 3.840 & -5.117 \\
\hline C & -2.227 & 0.845 & -5.880 \\
\hline $\mathrm{H}$ & -2.729 & -0.133 & -5.872 \\
\hline $\mathrm{H}$ & -1.217 & 0.721 & -6.274 \\
\hline $\mathrm{H}$ & -2.765 & 1.513 & -6.558 \\
\hline $\mathrm{H}$ & -0.639 & 1.231 & -3.060 \\
\hline $\mathrm{H}$ & -1.036 & -0.259 & -3.952 \\
\hline $\mathrm{H}$ & 0.292 & -0.868 & -0.458 \\
\hline $\mathrm{H}$ & 0.740 & 0.859 & -0.463 \\
\hline $\mathrm{H}$ & -1.495 & 3.506 & -2.650 \\
\hline $\mathrm{H}$ & -2.729 & 4.632 & -2.006 \\
\hline $\mathrm{H}$ & -1.597 & 4.229 & 1.210 \\
\hline $\mathrm{H}$ & -0.799 & 3.369 & -0.136 \\
\hline $\mathrm{H}$ & -4.224 & 3.852 & -3.642 \\
\hline
\end{tabular}




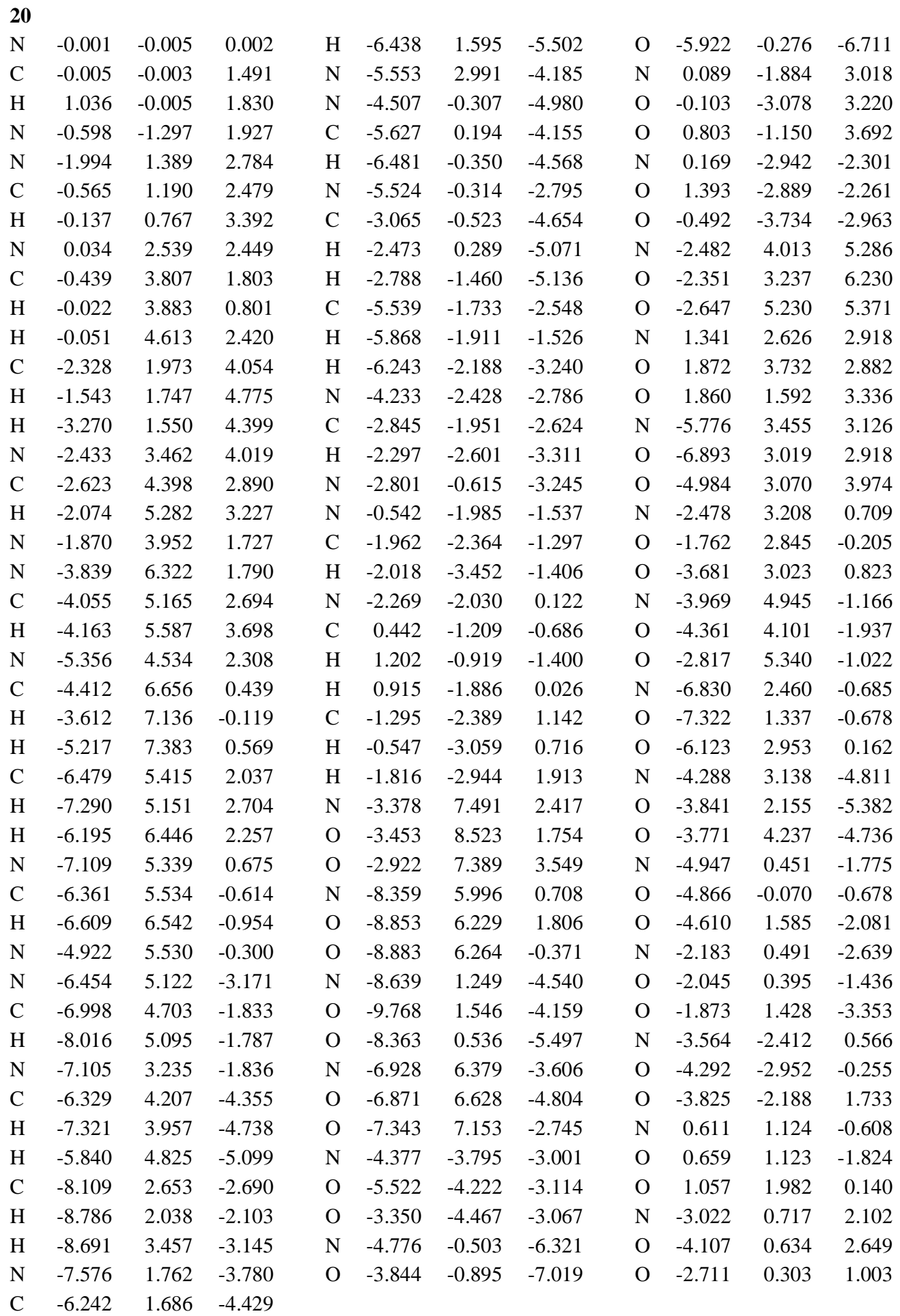




\begin{tabular}{|c|c|c|c|c|c|c|c|c|c|c|c|}
\hline \multicolumn{12}{|l|}{21} \\
\hline $\mathrm{N}$ & \multicolumn{11}{|c|}{777} \\
\hline \multicolumn{12}{|c|}{0.000} \\
\hline \multicolumn{2}{|c|}{1.051} & 0.000 & 1.796 & $\mathrm{H}$ & -7.853 & 2.771 & -4.513 & $\mathrm{O}$ & -4.941 & 10.236 & -0.377 \\
\hline & \multirow{2}{*}{$\begin{array}{l}-0.547 \\
-1.784\end{array}$} & -1.321 & 1.917 & $\mathrm{H}$ & -7.460 & 1.555 & -3.276 & $\mathrm{O}$ & -5.627 & 9.828 & 1.652 \\
\hline T & & 0.861 & 3.222 & $\mathrm{~N}$ & -6.032 & 1.862 & -4.765 & $\mathrm{~N}$ & -1.831 & 7.226 & 5.559 \\
\hline & \multirow{2}{*}{$\begin{array}{r}-0.582 \\
0.194\end{array}$} & 1.185 & 2.474 & $\mathrm{C}$ & -4.798 & 1.111 & -4.375 & $\mathrm{O}$ & -1.567 & 8.393 & 5.281 \\
\hline 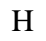 & & 1.174 & 3.239 & $\mathrm{H}$ & -4.001 & 1.595 & -4.944 & $\mathrm{O}$ & -1.582 & 6.653 & 6.608 \\
\hline $\mathrm{N}$ & -0.675 & 2.579 & 2.050 & $\mathrm{~N}$ & -4.436 & 1.387 & -3.004 & $\mathrm{~N}$ & 0.539 & 3.232 & 1.882 \\
\hline & -2.053 & 1.499 & 4.547 & $\mathrm{~N}$ & -3.424 & -0.659 & -5.566 & $\mathrm{O}$ & 0.524 & 4.446 & 1.739 \\
\hline $\mathrm{H}$ & -3.123 & 1.419 & 4.720 & $\mathrm{C}$ & -4.730 & -0.374 & -4.980 & $\mathrm{O}$ & 1.538 & 2.508 & 1.909 \\
\hline $\mathrm{H}$ & -1.513 & 0.952 & 5.316 & $\mathrm{H}$ & -5.380 & -0.284 & -5.850 & $\mathrm{~N}$ & 0.768 & -2.769 & -2.298 \\
\hline$C$ & -1.883 & 3.238 & 1.578 & $\mathrm{~N}$ & -5.207 & -1.538 & -4.202 & $\mathrm{O}$ & 1.973 & -2.578 & -2.217 \\
\hline $\mathrm{H}$ & -1.573 & 4.122 & 1.031 & $\mathrm{C}$ & -2.153 & -1.078 & -4.898 & $\mathrm{O}$ & 0.232 & -3.659 & -2.961 \\
\hline $\mathrm{H}$ & -2.435 & 2.575 & 0.919 & $\mathrm{H}$ & -1.885 & -2.079 & -5.237 & $\mathrm{~N}$ & -3.415 & -0.970 & -6.945 \\
\hline $\mathrm{N}$ & -2.805 & 3.642 & 2.675 & $\mathrm{H}$ & -1.360 & -0.395 & -5.192 & $\mathrm{O}$ & -2.318 & -1.299 & -7.388 \\
\hline C & -2.210 & 4.064 & 3.923 & $\mathrm{C}$ & -4.458 & -2.771 & -4.034 & $\mathrm{O}$ & -4.460 & -0.890 & -7.572 \\
\hline $\mathrm{H}$ & -1.327 & 4.619 & 3.602 & $\mathrm{H}$ & -5.189 & -3.575 & -4.018 & $\mathrm{~N}$ & -6.764 & 3.152 & -1.556 \\
\hline $\mathrm{N}$ & -1.653 & 2.896 & 4.673 & $\mathrm{H}$ & -3.794 & -2.927 & -4.884 & $\mathrm{O}$ & -5.999 & 3.770 & -0.815 \\
\hline $\mathrm{N}$ & -4.375 & 5.124 & 5.108 & $\mathrm{~N}$ & -3.704 & -2.910 & -2.779 & $\mathrm{O}$ & -7.630 & 2.363 & -1.227 \\
\hline $\mathrm{C}$ & -2.916 & 5.156 & 4.864 & $\mathrm{C}$ & -2.307 & -2.371 & -2.716 & $\mathrm{~N}$ & -3.457 & 6.251 & -1.605 \\
\hline $\mathrm{H}$ & -2.429 & 4.967 & 5.821 & $\mathrm{H}$ & -1.698 & -3.031 & -3.338 & $\mathrm{O}$ & -3.075 & 5.131 & -1.875 \\
\hline $\mathrm{N}$ & -2.489 & 6.511 & 4.532 & $\mathrm{~N}$ & -2.290 & -1.096 & -3.458 & $\mathrm{O}$ & -2.744 & 7.178 & -1.246 \\
\hline $\mathrm{C}$ & -5.242 & 6.286 & 5.011 & $\mathrm{~N}$ & -0.083 & -1.888 & -1.593 & $\mathrm{~N}$ & -7.148 & 4.992 & 1.167 \\
\hline $\mathrm{H}$ & -4.677 & 7.196 & 5.213 & $\mathrm{C}$ & -1.450 & -2.478 & -1.349 & $\mathrm{O}$ & -6.420 & 4.600 & 2.050 \\
\hline $\mathrm{H}$ & -5.998 & 6.172 & 5.784 & $\mathrm{H}$ & -1.295 & -3.555 & -1.289 & $\mathrm{O}$ & -8.178 & 4.475 & 0.779 \\
\hline $\mathrm{C}$ & -2.964 & 7.420 & 3.443 & $\mathrm{~N}$ & -1.924 & -2.009 & -0.035 & $\mathrm{~N}$ & -3.355 & 6.080 & 1.506 \\
\hline $\mathrm{H}$ & -2.106 & 7.751 & 2.863 & $\mathrm{C}$ & 0.726 & -1.096 & -0.599 & $\mathrm{O}$ & -4.105 & 5.441 & 0.794 \\
\hline $\mathrm{H}$ & -3.433 & 8.297 & 3.890 & $\mathrm{H}$ & 1.114 & -1.748 & 0.183 & $\mathrm{O}$ & -2.138 & 6.168 & 1.395 \\
\hline $\mathrm{N}$ & -3.927 & 6.765 & 2.585 & $\mathrm{H}$ & 1.570 & -0.717 & -1.165 & $\mathrm{~N}$ & -4.762 & 4.177 & 6.089 \\
\hline $\mathrm{C}$ & -5.349 & 7.151 & 2.609 & $\mathrm{C}$ & -1.154 & -2.441 & 1.101 & $\mathrm{O}$ & -3.893 & 3.388 & 6.439 \\
\hline $\mathrm{H}$ & -5.318 & 8.205 & 2.890 & $\mathrm{H}$ & -1.795 & -2.981 & 1.791 & $\mathrm{O}$ & -5.916 & 4.212 & 6.483 \\
\hline $\mathrm{N}$ & -5.994 & 6.433 & 3.756 & $\mathrm{H}$ & -0.365 & -3.125 & 0.779 & $\mathrm{~N}$ & -4.076 & 2.997 & 2.662 \\
\hline $\mathrm{N}$ & -6.715 & 6.180 & 0.451 & $\mathrm{~N}$ & -0.381 & 3.128 & 5.221 & $\mathrm{O}$ & -4.646 & 2.879 & 3.737 \\
\hline $\mathrm{C}$ & -6.128 & 7.305 & 1.199 & $\mathrm{O}$ & 0.284 & 2.156 & 5.564 & $\mathrm{O}$ & -4.487 & 2.650 & 1.573 \\
\hline $\mathrm{H}$ & -6.933 & 7.981 & 1.484 & $\mathrm{O}$ & -0.046 & 4.305 & 5.326 & $\mathrm{~N}$ & -2.893 & 0.386 & 2.514 \\
\hline $\mathrm{N}$ & -5.255 & 8.092 & 0.253 & $\mathrm{~N}$ & -7.384 & 6.518 & 3.921 & $\mathrm{O}$ & -2.753 & 0.327 & 1.294 \\
\hline $\mathrm{C}$ & -7.606 & 6.537 & -0.621 & $\mathrm{O}$ & -7.858 & 6.203 & 4.999 & $\mathrm{O}$ & -3.864 & 0.041 & 3.162 \\
\hline $\mathrm{H}$ & -7.748 & 7.620 & -0.645 & $\mathrm{O}$ & -8.036 & 6.887 & 2.941 & $\mathrm{~N}$ & 0.110 & 1.180 & -0.788 \\
\hline $\mathrm{H}$ & -8.578 & 6.083 & -0.453 & $\mathrm{~N}$ & -8.156 & 6.317 & -2.946 & $\mathrm{O}$ & -0.465 & 2.179 & -0.409 \\
\hline $\mathrm{C}$ & -5.140 & 7.870 & -1.232 & $\mathrm{O}$ & -9.231 & 6.747 & -2.539 & $\mathrm{O}$ & 0.713 & 1.064 & -1.846 \\
\hline $\mathrm{H}$ & -4.327 & 8.513 & -1.548 & $\mathrm{O}$ & -7.869 & 6.081 & -4.120 & $\mathrm{~N}$ & -3.350 & -1.967 & 0.237 \\
\hline $\mathrm{H}$ & -6.046 & 8.202 & -1.739 & $\mathrm{~N}$ & -5.953 & 2.461 & -6.033 & $\mathrm{O}$ & -4.057 & -1.561 & -0.656 \\
\hline $\mathrm{N}$ & -4.857 & 6.500 & -1.595 & $\mathrm{O}$ & -6.758 & 3.347 & -6.302 & $\mathrm{O}$ & -3.696 & -2.300 & 1.355 \\
\hline $\mathrm{C}$ & -5.813 & 5.909 & -2.581 & $\mathrm{O}$ & -5.080 & 2.027 & -6.780 & $\mathrm{~N}$ & -1.989 & 0.125 & -2.842 \\
\hline $\mathrm{H}$ & -5.793 & 6.569 & -3.452 & $\mathrm{~N}$ & -4.029 & -4.053 & -2.034 & $\mathrm{O}$ & -2.158 & 0.197 & -1.640 \\
\hline $\mathrm{N}$ & -7.174 & 6.055 & -1.988 & $\mathrm{O}$ & -5.050 & -4.655 & -2.317 & $\mathrm{O}$ & -1.605 & 1.023 & -3.582 \\
\hline $\mathrm{N}$ & -6.638 & 3.438 & -2.918 & $\mathrm{O}$ & -3.261 & -4.354 & -1.118 & $\mathrm{~N}$ & -6.615 & -1.698 & -4.230 \\
\hline $\mathrm{C}$ & -5.676 & 4.449 & -3.321 & $\mathrm{~N}$ & 0.060 & -1.815 & 3.074 & $\mathrm{O}$ & -7.248 & -0.762 & -4.705 \\
\hline $\mathrm{H}$ & -6.016 & 4.728 & -4.318 & $\mathrm{O}$ & -0.103 & -3.005 & 3.323 & $\mathrm{O}$ & -7.076 & -2.729 & -3.769 \\
\hline $\mathrm{N}$ & -4.389 & 3.791 & -3.529 & $\mathrm{O}$ & 0.696 & -1.013 & 3.757 & $\mathrm{~N}$ & -5.166 & 0.798 & -1.930 \\
\hline $\mathrm{C}$ & -3.846 & 2.721 & -2.706 & $\mathrm{~N}$ & -3.549 & 4.405 & -4.449 & $\mathrm{O}$ & -6.055 & 0.015 & -2.231 \\
\hline $\mathrm{H}$ & -4.029 & 2.929 & -1.656 & $\mathrm{O}$ & -2.560 & 3.791 & -4.823 & $\mathrm{O}$ & -4.814 & 1.110 & -0.810 \\
\hline
\end{tabular}




$\begin{array}{lrrr}\mathbf{2 2} & & & \\ \mathrm{C} & 0.214 & -0.380 & -0.103 \\ \mathrm{~N} & 0.215 & -0.556 & 1.400 \\ \mathrm{C} & 1.262 & 0.279 & 1.928 \\ \mathrm{~N} & 2.204 & 0.012 & 3.038 \\ \mathrm{C} & 3.244 & 1.026 & 2.751 \\ \mathrm{~N} & 3.243 & 1.202 & 1.247 \\ \mathrm{C} & 2.195 & 0.367 & 0.720 \\ \mathrm{~N} & 1.254 & 0.634 & -0.391 \\ \mathrm{H} & 0.864 & 1.271 & 2.182 \\ \mathrm{H} & 2.593 & -0.625 & 0.465 \\ \mathrm{H} & 2.953 & 1.965 & 3.221 \\ \mathrm{H} & 4.221 & 0.707 & 3.106 \\ \mathrm{H} & -0.763 & -0.061 & -0.459 \\ \mathrm{H} & 0.505 & -1.319 & -0.574 \\ \mathrm{~N} & 0.769 & 1.976 & -0.545 \\ \mathrm{O} & 1.579 & 2.864 & -0.332 \\ \mathrm{O} & -0.377 & 2.102 & -0.955 \\ \mathrm{~N} & -1.032 & -0.467 & 2.042 \\ \mathrm{O} & -1.011 & -0.056 & 3.196 \\ \mathrm{O} & -2.000 & -0.858 & 1.402 \\ \mathrm{~N} & 2.688 & -1.331 & 3.192 \\ \mathrm{O} & 3.834 & -1.456 & 3.600 \\ \mathrm{O} & 1.877 & -2.217 & 2.980 \\ \mathrm{~N} & 4.490 & 1.113 & 0.605 \\ \mathrm{O} & 4.468 & 0.701 & -0.549 \\ \mathrm{O} & 5.457 & 1.503 & 1.245\end{array}$

$\begin{array}{lrrrlrrr}\mathbf{2 3} & & & & \mathbf{2 4} & & & \\ \mathrm{C} & -0.005 & 0.000 & 0.000 & \mathrm{~N} & 0.009 & 0.005 & 0.006 \\ \mathrm{~N} & 0.001 & 0.014 & 1.461 & \mathrm{C} & 0.002 & 0.001 & 1.500 \\ \mathrm{C} & 1.348 & 0.001 & 2.072 & \mathrm{~N} & 1.491 & -0.008 & 1.382 \\ \mathrm{C} & 2.330 & -0.225 & 0.906 & \mathrm{C} & 1.267 & -0.793 & 0.131 \\ \mathrm{C} & 2.269 & 0.974 & -0.059 & \mathrm{C} & 0.734 & -2.262 & 0.491 \\ \mathrm{~N} & 0.849 & 1.095 & -0.457 & \mathrm{~N} & 0.727 & -2.266 & 1.986 \\ \mathrm{C} & 1.947 & -1.513 & 0.152 & \mathrm{C} & -0.531 & -1.468 & 1.861 \\ \mathrm{~N} & 0.614 & -1.251 & -0.432 & \mathrm{~N} & -0.755 & -2.254 & 0.610 \\ \mathrm{H} & 3.345 & -0.323 & 1.299 & \mathrm{H} & -0.474 & 0.831 & 2.015 \\ \mathrm{H} & 2.659 & -1.748 & -0.643 & \mathrm{H} & 2.001 & -0.724 & -0.665 \\ \mathrm{H} & 1.896 & -2.371 & 0.830 & \mathrm{H} & -1.265 & -1.537 & 2.657 \\ \mathrm{H} & 1.408 & -0.797 & 2.816 & \mathrm{H} & 1.210 & -3.092 & -0.023 \\ \mathrm{H} & 1.540 & 0.953 & 2.576 & \mathrm{~N} & -1.644 & -1.881 & -0.426 \\ \mathrm{H} & 2.598 & 1.901 & 0.420 & \mathrm{O} & -1.312 & -2.220 & -1.552 \\ \mathrm{H} & 2.892 & 0.807 & -0.943 & \mathrm{O} & -2.686 & -1.356 & -0.062 \\ \mathrm{H} & -1.012 & 0.098 & -0.391 & \mathrm{~N} & 0.185 & 1.309 & -0.588 \\ \mathrm{~N} & -0.219 & -2.353 & -0.641 & \mathrm{O} & 0.899 & 1.346 & -1.574 \\ \mathrm{O} & 0.348 & -3.441 & -0.699 & \mathrm{O} & -0.470 & 2.207 & -0.091 \\ \mathrm{O} & -1.416 & -2.136 & -0.789 & \mathrm{~N} & 2.380 & -0.381 & 2.418 \\ \mathrm{~N} & -0.986 & 0.759 & 2.110 & \mathrm{O} & 3.421 & -0.906 & 2.054 \\ \mathrm{O} & -0.773 & 1.000 & 3.296 & \mathrm{O} & 2.048 & -0.042 & 3.544 \\ \mathrm{O} & -1.980 & 1.065 & 1.462 & \mathrm{~N} & 0.551 & -3.570 & 2.580 \\ \mathrm{~N} & 0.583 & 1.650 & -1.710 & \mathrm{O} & 1.206 & -4.468 & 2.083 \\ \mathrm{O} & 1.485 & 2.334 & -2.189 & \mathrm{O} & -0.163 & -3.607 & 3.566 \\ \mathrm{O} & -0.524 & 1.445 & -2.195 & & & & \end{array}$

$\begin{array}{lrrr}\mathbf{2 5} & & & \\ \mathrm{N} & 0.006 & 0.006 & 0.004 \\ \mathrm{C} & 0.000 & 0.001 & 1.472 \\ \mathrm{~N} & 1.479 & -0.007 & 1.662 \\ \mathrm{C} & 1.689 & -1.366 & 1.147 \\ \mathrm{C} & 0.701 & -1.306 & -0.149 \\ \mathrm{~N} & -0.393 & -2.147 & 0.354 \\ \mathrm{C} & -0.423 & -1.554 & 1.722 \\ \mathrm{~N} & 0.873 & -2.077 & 2.173 \\ \mathrm{H} & -0.541 & 0.795 & 1.972 \\ \mathrm{H} & 2.711 & -1.704 & 1.031 \\ \mathrm{H} & -1.292 & -1.788 & 2.324 \\ \mathrm{H} & 1.088 & -1.528 & -1.135 \\ \mathrm{~N} & 0.591 & 1.161 & -0.599 \\ \mathrm{O} & 1.271 & 0.958 & -1.593 \\ \mathrm{O} & 0.286 & 2.230 & -0.099 \\ \mathrm{~N} & -1.588 & -2.123 & -0.427 \\ \mathrm{O} & -2.636 & -2.123 & 0.200 \\ \mathrm{O} & -1.432 & -2.181 & -1.634 \\ \mathrm{~N} & 2.001 & 0.237 & 2.969 \\ \mathrm{O} & 1.309 & 0.929 & 3.699 \\ \mathrm{O} & 3.113 & -0.211 & 3.186 \\ \mathrm{~N} & 0.963 & -3.501 & 2.249 \\ \mathrm{O} & 2.021 & -3.989 & 1.882 \\ \mathrm{O} & 0.002 & -4.066 & 2.741\end{array}$




$\begin{array}{lrrr}\varepsilon-C L-20 & & \\ \mathrm{H} & -0.007 & 0.003 & -0.008 \\ \mathrm{C} & -0.011 & -0.003 & 1.080 \\ \mathrm{~N} & 1.348 & -0.012 & 1.563 \\ \mathrm{C} & 1.552 & -0.028 & 2.994 \\ \mathrm{C} & 0.799 & 1.222 & 3.625 \\ \mathrm{~N} & 0.157 & 1.961 & 2.562 \\ \mathrm{C} & -0.765 & 1.249 & 1.712 \\ \mathrm{~N} & -1.857 & 0.650 & 2.502 \\ \mathrm{C} & -1.495 & -0.744 & 2.782 \\ \mathrm{~N} & -0.762 & -1.168 & 1.584 \\ \mathrm{C} & -0.493 & -0.773 & 4.032 \\ \mathrm{~N} & 0.866 & -1.147 & 3.662 \\ \mathrm{~N} & -0.161 & 0.559 & 4.525 \\ \mathrm{H} & 2.620 & -0.033 & 3.198 \\ \mathrm{H} & -0.883 & -1.407 & 4.824 \\ \mathrm{H} & 1.460 & 1.892 & 4.169 \\ \mathrm{H} & -1.167 & 1.930 & 0.965 \\ \mathrm{H} & -2.370 & -1.362 & 2.960 \\ \mathrm{~N} & 2.426 & -0.259 & 0.681 \\ \mathrm{~N} & 1.146 & -2.463 & 3.308 \\ \mathrm{~N} & -1.120 & 1.299 & 5.209 \\ \mathrm{~N} & 0.252 & 3.370 & 2.505 \\ \mathrm{~N} & -3.202 & 0.893 & 2.056 \\ \mathrm{~N} & -1.491 & -1.947 & 0.621 \\ \mathrm{O} & 2.132 & -0.412 & -0.494 \\ \mathrm{O} & 3.540 & -0.249 & 1.177 \\ \mathrm{O} & 2.210 & -2.649 & 2.732 \\ \mathrm{O} & 0.315 & -3.300 & 3.645 \\ \mathrm{O} & -2.075 & 0.668 & 5.648 \\ \mathrm{O} & -0.887 & 2.494 & 5.332 \\ \mathrm{O} & -0.458 & 3.923 & 1.680 \\ \mathrm{O} & 1.064 & 3.885 & 3.256 \\ \mathrm{O} & -3.366 & 1.878 & 1.355 \\ \mathrm{O} & -4.048 & 0.123 & 2.476 \\ \mathrm{O} & -2.374 & -2.656 & 1.070 \\ \mathrm{O} & -1.109 & -1.866 & -0.535\end{array}$

$\begin{array}{lrrr}\text { 26 } & & & \\ \mathrm{H} & -0.015 & 0.024 & -0.003 \\ \mathrm{C} & -0.010 & 0.017 & 1.083 \\ \mathrm{~N} & 1.363 & 0.013 & 1.580 \\ \mathrm{C} & 1.421 & 0.036 & 3.049 \\ \mathrm{C} & 0.623 & 1.285 & 3.631 \\ \mathrm{~N} & 0.140 & 2.027 & 2.480 \\ \mathrm{C} & -0.814 & 1.270 & 1.668 \\ \mathrm{~N} & -1.900 & 0.718 & 2.479 \\ \mathrm{C} & -1.427 & -0.030 & 3.630 \\ \mathrm{~N} & -0.581 & -1.233 & 1.580 \\ \mathrm{C} & -0.625 & -1.276 & 3.049 \\ \mathrm{~N} & 0.743 & -1.158 & 3.535 \\ \mathrm{~N} & -0.545 & 0.850 & 4.412 \\ \mathrm{H} & 2.457 & 0.041 & 3.372 \\ \mathrm{H} & -1.062 & -2.215 & 3.372 \\ \mathrm{H} & 1.261 & 1.910 & 4.247 \\ \mathrm{H} & -1.218 & 1.901 & 0.882 \\ \mathrm{H} & -2.261 & -0.349 & 4.247 \\ \mathrm{~N} & 2.287 & 0.833 & 0.887 \\ \mathrm{~N} & 1.520 & -2.370 & 3.531 \\ \mathrm{~N} & -0.303 & 0.472 & 5.755 \\ \mathrm{~N} & -0.057 & 3.436 & 2.634 \\ \mathrm{~N} & -3.097 & 1.489 & 2.637 \\ \mathrm{~N} & -1.711 & -1.730 & 0.888 \\ \mathrm{O} & 2.008 & 1.104 & -0.272 \\ \mathrm{O} & 3.295 & 1.146 & 1.504 \\ \mathrm{O} & 0.886 & -3.410 & 3.557 \\ \mathrm{O} & 2.730 & -2.227 & 3.559 \\ \mathrm{O} & -1.146 & -0.244 & 6.275 \\ \mathrm{O} & 0.701 & 0.938 & 6.275 \\ \mathrm{O} & -0.684 & 3.985 & 1.746 \\ \mathrm{O} & 0.476 & 3.949 & 3.605 \\ \mathrm{O} & -3.332 & 2.290 & 1.750 \\ \mathrm{O} & -3.785 & 1.218 & 3.607 \\ \mathrm{O} & -2.416 & -2.516 & 1.505 \\ & -1.843 & -1.364 & -0.271\end{array}$

\begin{tabular}{|c|c|c|c|}
\hline & & & \\
\hline $\mathrm{N}$ & -0.019 & -0.005 & -0.006 \\
\hline 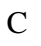 & -0.002 & 0.000 & 1.451 \\
\hline & 1.343 & 0.004 & 1.997 \\
\hline & 2.125 & 1.155 & 2.413 \\
\hline & 1.195 & 2.293 & 2.974 \\
\hline $\mathbf{N}$ & 1.286 & 3.487 & 2.154 \\
\hline & 3.014 & 1.642 & 1.368 \\
\hline & -0.176 & 1.836 & 3.157 \\
\hline 0 & -0.854 & 1.181 & 2.047 \\
\hline $\mathbf{N}$ & -1.254 & 2.108 & 1.004 \\
\hline & -2.501 & 2.766 & 1.191 \\
\hline $\mathrm{N}$ & -1.003 & -0.840 & -0.622 \\
\hline $\mathrm{N}$ & 1.971 & -1.264 & 2.133 \\
\hline$\sqrt{2}$ & -0.517 & 1.372 & 4.467 \\
\hline 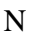 & 1.114 & 4.727 & 2.828 \\
\hline $\mathrm{N}$ & 4.318 & 2.050 & 1.790 \\
\hline $\mathrm{O}$ & -2.833 & 3.550 & 0.315 \\
\hline $\mathrm{O}$ & -3.112 & 2.484 & 2.210 \\
\hline $\mathrm{O}$ & -1.514 & -1.694 & 0.086 \\
\hline $\mathrm{O}$ & -1.228 & -0.635 & -1.805 \\
\hline $\mathrm{O}$ & 1.316 & -2.231 & 1.776 \\
\hline $\mathrm{O}$ & 3.105 & -1.259 & 2.587 \\
\hline $\mathrm{O}$ & -1.546 & 0.721 & 4.563 \\
\hline $\mathrm{O}$ & 0.242 & 1.686 & 5.371 \\
\hline $\mathrm{O}$ & 1.185 & 5.731 & 2.136 \\
\hline $\mathrm{O}$ & 0.907 & 4.664 & 4.030 \\
\hline $\mathrm{O}$ & 4.959 & 2.727 & 1.000 \\
\hline $\mathrm{O}$ & 4.679 & 1.668 & 2.892 \\
\hline $\mathrm{H}$ & -1.767 & 0.762 & 2.465 \\
\hline $\mathrm{H}$ & -0.463 & -0.937 & 1.755 \\
\hline $\mathrm{H}$ & 1.551 & 2.562 & 3.966 \\
\hline $\mathrm{H}$ & 2.774 & 0.821 & 3.220 \\
\hline C & 0.318 & 1.221 & -0.716 \\
\hline $\mathrm{H}$ & 0.053 & 1.041 & -1.756 \\
\hline O & -0.523 & 2.448 & -0.203 \\
\hline $\mathrm{H}$ & -1.263 & 2.692 & -0.963 \\
\hline $\mathrm{C}$ & 2.443 & 2.376 & 0.247 \\
\hline $\mathrm{H}$ & 3.290 & 2.800 & -0.290 \\
\hline C & 1.525 & 3.561 & 0.724 \\
\hline $\mathrm{H}$ & 2.053 & 4.494 & 0.540 \\
\hline $\mathrm{N}$ & 1.738 & 1.517 & -0.688 \\
\hline $\mathrm{N}$ & 0.294 & 3.644 & -0.051 \\
\hline $\mathrm{N}$ & 0.312 & 4.541 & -1.166 \\
\hline $\mathrm{O}$ & 1.205 & 5.375 & -1.180 \\
\hline $\mathrm{O}$ & -0.578 & 4.404 & -1.990 \\
\hline $\mathrm{N}$ & 2.531 & 0.892 & -1.689 \\
\hline $\mathrm{O}$ & 3.727 & 1.139 & -1.662 \\
\hline O & 1.938 & 0.167 & -2.472 \\
\hline
\end{tabular}




\begin{tabular}{|c|c|c|c|}
\hline & & & \\
\hline & -0.010 & .005 & 1.474 \\
\hline & 1.318 & 0.002 & 2.068 \\
\hline & 2.087 & 1.129 & 2.608 \\
\hline & 1.192 & 2.382 & 2.885 \\
\hline & 1.458 & 3.477 & 1.946 \\
\hline & 3.242 & 1.474 & 1.799 \\
\hline & -0.213 & 2.020 & 2.960 \\
\hline & -0.814 & 1.285 & 1.871 \\
\hline & -0.813 & 2.066 & 0.638 \\
\hline & -1.917 & 2.899 & 0.389 \\
\hline & -0.844 & -0.997 & -0.636 \\
\hline & 1.873 & -1.278 & 2.337 \\
\hline & -0.785 & 1.857 & 4.251 \\
\hline & 1.168 & 4.773 & 2.450 \\
\hline & 4.484 & 1.664 & 2.464 \\
\hline & -2.029 & 3.317 & -0.756 \\
\hline 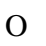 & -2.625 & 3.152 & 1.355 \\
\hline 0 & -1.139 & -1.971 & 0.034 \\
\hline O & -1.118 & -0.786 & -1.806 \\
\hline $\mathrm{O}$ & 1.232 & -2.241 & 1.946 \\
\hline O & 2.947 & -1.285 & 2.922 \\
\hline $\mathrm{O}$ & -1.902 & 1.361 & 4.289 \\
\hline O & -0.114 & 2.232 & 5.199 \\
\hline 0 & 0.671 & 4.817 & 3.566 \\
\hline $\mathrm{O}$ & & 5.713 & \\
\hline $\mathrm{O}$ & 5.390 & 2.137 & 1.794 \\
\hline $\mathrm{O}$ & 4.533 & 1.334 & 3.638 \\
\hline $\mathrm{H}$ & -1.830 & 1.030 & 2.175 \\
\hline $\mathrm{H}$ & -0.516 & -0.903 & 1.802 \\
\hline $\mathrm{H}$ & 1.447 & 2.749 & 3.878 \\
\hline $\mathrm{H}$ & 2.493 & 0.803 & 3.564 \\
\hline 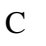 & 1.136 & & \\
\hline $\mathrm{H}$ & 1.166 & 1.953 & -2.063 \\
\hline $\mathrm{C}$ & -0.217 & 1.362 & -0.502 \\
\hline $\mathrm{H}$ & -0.905 & 1.370 & -1.347 \\
\hline $\mathrm{C}$ & 3.050 & 2.160 & 0.543 \\
\hline $\mathrm{H}$ & 4.039 & 2.416 & 0.160 \\
\hline $\mathrm{C}$ & 2.152 & 3.434 & 0.668 \\
\hline $\mathrm{H}$ & 2.742 & 4.347 & 0.587 \\
\hline $\mathrm{N}$ & 2.313 & 1.335 & -0.410 \\
\hline $\mathrm{N}$ & 1.268 & 3.379 & -0.510 \\
\hline $\mathrm{N}$ & 1.525 & 4.346 & -1.551 \\
\hline $\mathrm{O}$ & 2.156 & 5.338 & -1.234 \\
\hline $\mathrm{O}$ & 1.035 & 4.089 & -2.638 \\
\hline $\mathrm{N}$ & 3.052 & 0.484 & -1.251 \\
\hline $\mathrm{O}$ & 4.205 & 0.261 & -0.905 \\
\hline $\mathrm{O}$ & 2.453 & 0.025 & -2.214 \\
\hline
\end{tabular}

\begin{tabular}{|c|c|c|c|c|c|c|c|}
\hline 29 & & & & 30 & & & \\
\hline $\mathrm{N}$ & -0.009 & -0.001 & 0.008 & $\mathrm{~N}$ & -0.027 & 0.005 & -0.005 \\
\hline C & -0.009 & 0.002 & 1.471 & $\mathrm{C}$ & -0.009 & -0.002 & 1.455 \\
\hline $\mathrm{N}$ & 1.361 & 0.005 & 1.956 & $\mathrm{~N}$ & 1.341 & -0.007 & 2.015 \\
\hline C & 2.292 & -1.121 & 1.948 & $\mathrm{C}$ & 1.629 & 1.132 & 2.900 \\
\hline $\mathrm{N}$ & 1.980 & -2.083 & 2.982 & $\mathrm{C}$ & 2.781 & 2.077 & 2.391 \\
\hline C & 0.781 & -2.894 & 2.823 & $\mathrm{~N}$ & 2.323 & 3.191 & 1.547 \\
\hline C & 0.998 & -3.726 & 1.479 & $\mathrm{~N}$ & 3.721 & 1.372 & 1.525 \\
\hline $\mathrm{N}$ & 2.282 & -3.383 & 0.866 & $\mathrm{~N}$ & 0.347 & 1.827 & 2.970 \\
\hline C & 2.500 & -1.960 & 0.608 & $\mathrm{C}$ & -0.532 & 1.395 & 1.887 \\
\hline $\mathrm{N}$ & 1.741 & -1.531 & -0.544 & $\mathrm{~N}$ & -0.365 & 2.175 & 0.662 \\
\hline C & 0.321 & -1.277 & -0.624 & $\mathrm{~N}$ & -1.229 & 3.263 & 0.457 \\
\hline C & -0.639 & -2.425 & -0.075 & $\mathrm{~N}$ & -0.950 & -0.880 & -0.649 \\
\hline $\mathrm{N}$ & -1.540 & -1.788 & 0.860 & $\mathrm{~N}$ & 1.906 & -1.249 & 2.350 \\
\hline C & -0.968 & -1.144 & 2.033 & $\mathrm{~N}$ & -0.234 & 1.947 & 4.273 \\
\hline $\mathrm{N}$ & -0.430 & -2.109 & 2.975 & $\mathrm{~N}$ & 2.164 & 4.446 & 2.158 \\
\hline $\mathrm{N}$ & -0.053 & -3.643 & 0.481 & $\mathrm{~N}$ & 5.066 & 1.273 & 2.002 \\
\hline $\mathrm{H}$ & 3.546 & -1.858 & 0.330 & $\mathrm{O}$ & -1.300 & 3.688 & -0.689 \\
\hline $\mathrm{H}$ & 1.063 & -4.772 & 1.767 & $\mathrm{O}$ & -1.790 & 3.693 & 1.455 \\
\hline $\mathrm{H}$ & 3.254 & -0.678 & 2.193 & $\mathrm{O}$ & -1.335 & -1.837 & 0.002 \\
\hline $\mathrm{H}$ & 0.759 & -3.614 & 3.638 & $\mathrm{O}$ & -1.220 & -0.609 & -1.808 \\
\hline $\mathrm{H}$ & -1.776 & -0.645 & 2.564 & $\mathrm{O}$ & 1.396 & -2.226 & 1.819 \\
\hline $\mathrm{H}$ & 0.099 & -1.159 & -1.682 & $\mathrm{O}$ & 2.868 & -1.220 & 3.106 \\
\hline $\mathrm{H}$ & -0.443 & 0.949 & 1.778 & $\mathrm{O}$ & -1.444 & 2.092 & 4.320 \\
\hline $\mathrm{H}$ & -1.231 & -2.769 & -0.918 & $\mathrm{O}$ & 0.554 & 1.941 & 5.205 \\
\hline $\mathrm{N}$ & -1.058 & 0.747 & -0.618 & $\mathrm{O}$ & 2.049 & 4.443 & 3.377 \\
\hline $\mathrm{O}$ & -1.612 & 1.588 & 0.071 & $\mathrm{O}$ & 2.120 & 5.405 & 1.401 \\
\hline $\mathrm{O}$ & -1.271 & 0.500 & -1.795 & $\mathrm{O}$ & 5.935 & 1.121 & 1.160 \\
\hline $\mathrm{N}$ & -2.835 & -2.364 & 0.997 & $\mathrm{O}$ & 5.199 & 1.303 & 3.215 \\
\hline $\mathrm{O}$ & -3.479 & -2.014 & 1.973 & $\mathrm{H}$ & -1.564 & 1.417 & 2.240 \\
\hline $\mathrm{O}$ & -3.184 & -3.125 & 0.108 & $\mathrm{H}$ & -0.595 & -0.850 & 1.811 \\
\hline $\mathrm{N}$ & 1.976 & 1.313 & 1.935 & $\mathrm{H}$ & 3.286 & 2.465 & 3.276 \\
\hline $\mathrm{O}$ & 3.195 & 1.350 & 1.963 & $\mathrm{H}$ & 1.928 & 0.771 & 3.884 \\
\hline $\mathrm{O}$ & 1.214 & 2.265 & 1.910 & $\mathrm{C}$ & 1.417 & 1.736 & -1.122 \\
\hline $\mathrm{N}$ & 2.488 & -1.349 & -1.763 & $\mathrm{H}$ & 1.348 & 1.569 & -2.197 \\
\hline $\mathrm{O}$ & 1.849 & -1.025 & -2.749 & $\mathrm{C}$ & 0.011 & 1.373 & -0.513 \\
\hline $\mathrm{O}$ & 3.691 & -1.535 & -1.695 & $\mathrm{H}$ & -0.723 & 1.513 & -1.306 \\
\hline $\mathrm{N}$ & 2.370 & -1.748 & 4.309 & $\mathrm{C}$ & 3.534 & 1.770 & 0.132 \\
\hline $\mathrm{O}$ & 3.199 & -0.859 & 4.420 & $\mathrm{H}$ & 4.499 & 1.746 & -0.375 \\
\hline $\mathrm{O}$ & 1.862 & -2.407 & 5.203 & $\mathrm{C}$ & 2.844 & 3.160 & 0.183 \\
\hline $\mathrm{N}$ & 3.419 & -4.102 & 1.357 & $\mathrm{H}$ & 3.495 & 4.011 & -0.020 \\
\hline $\mathrm{O}$ & 4.514 & -3.617 & 1.115 & $\mathrm{~N}$ & 2.538 & 0.960 & -0.568 \\
\hline $\mathrm{O}$ & 3.190 & -5.154 & 1.934 & $\mathrm{~N}$ & 1.795 & 3.116 & -0.834 \\
\hline $\mathrm{N}$ & -1.182 & -2.312 & 4.191 & $\mathrm{~N}$ & 1.952 & 3.975 & -1.968 \\
\hline $\mathrm{O}$ & -1.924 & -1.404 & 4.523 & $\mathrm{O}$ & 2.678 & 4.945 & -1.823 \\
\hline $\mathrm{O}$ & -1.002 & -3.370 & 4.766 & $\mathrm{O}$ & 1.298 & 3.673 & -2.953 \\
\hline $\mathrm{N}$ & -0.137 & -4.811 & -0.368 & $\mathrm{~N}$ & 2.997 & -0.138 & -1.315 \\
\hline $\mathrm{O}$ & -0.711 & -4.676 & -1.435 & $\mathrm{O}$ & 4.113 & -0.549 & -1.026 \\
\hline $\mathrm{O}$ & 0.363 & -5.832 & 0.072 & $\mathrm{O}$ & 2.220 & -0.590 & -2.146 \\
\hline
\end{tabular}




$\begin{array}{lrrr}\text { 31 } & & & \\ \mathrm{H} & -0.078 & -0.008 & -0.054 \\ \mathrm{C} & -0.032 & -0.004 & 1.040 \\ \mathrm{C} & 1.418 & -0.004 & 1.591 \\ \mathrm{~N} & 1.548 & 1.196 & 2.439 \\ \mathrm{C} & 0.280 & 1.950 & 2.405 \\ \mathrm{~N} & -0.691 & 1.197 & 1.588 \\ \mathrm{C} & -1.821 & 0.780 & 2.442 \\ \mathrm{~N} & -1.543 & 1.206 & 3.827 \\ \mathrm{C} & -0.272 & 1.956 & 3.855 \\ \mathrm{~N} & 0.696 & 1.205 & 4.678 \\ \mathrm{C} & 1.824 & 0.779 & 3.827 \\ \mathrm{C} & 1.821 & -0.773 & 3.833 \\ \mathrm{~N} & 1.544 & -1.199 & 2.447 \\ \mathrm{C} & 0.273 & -1.949 & 2.419 \\ \mathrm{C} & -0.279 & -1.943 & 3.869 \\ \mathrm{~N} & 0.692 & -1.190 & 4.686 \\ \mathrm{C} & 0.033 & 0.011 & 5.235 \\ \mathrm{C} & -1.417 & 0.011 & 4.684 \\ \mathrm{~N} & -1.547 & -1.189 & 3.836 \\ \mathrm{C} & -1.823 & -0.772 & 2.447 \\ \mathrm{~N} & -0.695 & -1.198 & 1.597 \\ \mathrm{H} & -0.423 & 2.963 & 4.255 \\ \mathrm{H} & 0.434 & 2.954 & 1.998 \\ \mathrm{H} & -2.177 & 0.015 & 5.471 \\ \mathrm{H} & -2.759 & 1.212 & 2.083 \\ \mathrm{H} & 2.760 & -1.205 & 4.192 \\ \mathrm{H} & 0.424 & -2.956 & 2.019 \\ \mathrm{H} & 2.178 & -0.008 & 0.804 \\ \mathrm{H} & -2.764 & -1.203 & 2.092 \\ \mathrm{H} & -0.433 & -2.946 & 4.276 \\ \mathrm{H} & 0.079 & 0.015 & 6.328 \\ \mathrm{H} & 2.765 & 1.210 & 4.183\end{array}$

$\begin{array}{lrrr}\text { 31-H } & & & \\ \mathrm{H} & -0.078 & -0.007 & -0.057 \\ \mathrm{C} & -0.030 & 0.001 & 1.034 \\ \mathrm{C} & 1.420 & 0.005 & 1.587 \\ \mathrm{~N} & 1.548 & 1.198 & 2.441 \\ \mathrm{C} & 0.275 & 1.956 & 2.404 \\ \mathrm{~N} & -0.688 & 1.192 & 1.595 \\ \mathrm{C} & -1.824 & 0.780 & 2.435 \\ \mathrm{~N} & -1.545 & 1.204 & 3.827 \\ \mathrm{C} & -0.281 & 1.959 & 3.853 \\ \mathrm{~N} & 0.689 & 1.186 & 4.664 \\ \mathrm{C} & 1.835 & 0.785 & 3.818 \\ \mathrm{C} & 1.863 & -0.770 & 3.799 \\ \mathrm{~N} & 1.527 & -1.189 & 2.461 \\ \mathrm{C} & 0.264 & -1.955 & 2.408 \\ \mathrm{C} & -0.321 & -1.970 & 3.850 \\ \mathrm{~N} & 0.702 & -1.208 & 4.709 \\ \mathrm{C} & 0.021 & 0.056 & 5.259 \\ \mathrm{C} & -1.426 & 0.024 & 4.688 \\ \mathrm{~N} & -1.526 & -1.179 & 3.832 \\ \mathrm{C} & -1.823 & -0.772 & 2.437 \\ \mathrm{~N} & -0.693 & -1.198 & 1.596 \\ \mathrm{H} & -0.419 & 2.957 & 4.274 \\ \mathrm{H} & 0.434 & 2.956 & 1.997 \\ \mathrm{H} & -2.187 & 0.011 & 5.472 \\ \mathrm{H} & -2.762 & 1.213 & 2.081 \\ \mathrm{H} & 2.775 & -1.223 & 4.196 \\ \mathrm{H} & 0.431 & -2.961 & 2.013 \\ \mathrm{H} & 2.190 & -0.019 & 0.814 \\ \mathrm{H} & -2.762 & -1.217 & 2.103 \\ \mathrm{H} & -0.442 & -2.962 & 4.293 \\ \mathrm{H} & 0.091 & 0.016 & 6.349 \\ \mathrm{H} & 2.767 & 1.218 & 4.189 \\ & 1.044 & -1.796 & 5.473\end{array}$




\begin{tabular}{|c|c|c|c|c|c|c|c|}
\hline \multicolumn{8}{|c|}{ CB[5] } \\
\hline $\mathrm{O}$ & 0.015 & 0.160 & 0.015 & $\mathrm{~N}$ & -1.156 & -7.379 & 1.660 \\
\hline $\mathrm{C}$ & 0.006 & 0.121 & 1.227 & C & -1.933 & -6.908 & 2.719 \\
\hline $\mathrm{N}$ & 1.120 & 0.012 & 2.059 & $\mathrm{O}$ & -1.678 & -7.013 & 3.900 \\
\hline C & 0.788 & 0.282 & 3.449 & $\mathrm{C}$ & -0.003 & -6.961 & -1.307 \\
\hline $\mathrm{H}$ & 1.217 & 1.249 & 3.752 & $\mathrm{H}$ & 0.057 & -8.046 & -1.465 \\
\hline $\mathrm{N}$ & 1.121 & -0.731 & 4.425 & $\mathrm{H}$ & 0.027 & -6.443 & -2.269 \\
\hline $\mathrm{C}$ & -0.002 & -1.383 & 4.932 & $\mathrm{C}$ & 0.001 & -8.221 & 1.918 \\
\hline $\mathrm{O}$ & -0.011 & -2.203 & 5.826 & $\mathrm{H}$ & -0.029 & -8.490 & 2.977 \\
\hline $\mathrm{N}$ & -1.117 & -0.876 & 4.263 & $\mathrm{H}$ & -0.062 & -9.126 & 1.301 \\
\hline C & -0.783 & 0.283 & 3.451 & $\mathrm{~N}$ & 1.280 & -7.583 & 1.689 \\
\hline $\mathrm{H}$ & -1.208 & 1.190 & 3.906 & $\mathrm{C}$ & 1.884 & -7.353 & 0.396 \\
\hline $\mathrm{N}$ & -1.117 & 0.235 & 2.045 & $\mathrm{H}$ & 2.136 & -8.315 & -0.075 \\
\hline C & -2.451 & 0.092 & 1.502 & $\mathrm{~N}$ & 1.156 & -6.521 & -0.548 \\
\hline $\mathrm{H}$ & -2.391 & 0.378 & 0.449 & C & 1.924 & -5.445 & -0.994 \\
\hline $\mathrm{H}$ & -3.129 & 0.771 & 2.035 & $\mathrm{O}$ & 1.664 & -4.714 & -1.926 \\
\hline $\mathrm{C}$ & -2.458 & -1.202 & 4.719 & $\mathrm{~N}$ & 3.075 & -5.400 & -0.209 \\
\hline $\mathrm{H}$ & -3.039 & -0.277 & 4.829 & C & 3.152 & -6.491 & 0.737 \\
\hline $\mathrm{H}$ & -2.355 & -1.695 & 5.688 & $\mathrm{H}$ & 4.094 & -7.042 & 0.596 \\
\hline $\mathrm{N}$ & -3.184 & -2.117 & 3.864 & $\mathrm{~N}$ & 2.974 & -6.175 & 2.144 \\
\hline $\mathrm{C}$ & -3.827 & -1.771 & 2.617 & $\mathrm{C}$ & 1.947 & -6.922 & 2.721 \\
\hline $\mathrm{H}$ & -4.658 & -1.074 & 2.804 & $\mathrm{O}$ & 1.708 & -7.022 & 3.906 \\
\hline $\mathrm{N}$ & -2.987 & -1.258 & 1.548 & $\mathrm{C}$ & 3.955 & -4.252 & -0.243 \\
\hline $\mathrm{C}$ & -3.120 & -2.004 & 0.376 & $\mathrm{H}$ & 3.821 & -3.784 & -1.221 \\
\hline $\mathrm{O}$ & -2.714 & -1.695 & -0.724 & $\mathrm{H}$ & 4.993 & -4.592 & -0.129 \\
\hline $\mathrm{N}$ & -3.856 & -3.146 & 0.690 & $\mathrm{C}$ & 3.981 & -5.543 & 2.980 \\
\hline C & -4.310 & -3.160 & 2.063 & $\mathrm{H}$ & 3.844 & -5.930 & 3.992 \\
\hline $\mathrm{H}$ & -5.404 & -3.275 & 2.094 & $\mathrm{H}$ & 4.980 & -5.808 & 2.609 \\
\hline $\mathrm{N}$ & -3.691 & -4.115 & 2.967 & $\mathrm{~N}$ & 3.880 & -4.101 & 3.071 \\
\hline $\mathrm{C}$ & -3.146 & -3.492 & 4.090 & C & 4.312 & -3.164 & 2.059 \\
\hline $\mathrm{O}$ & -2.757 & -4.041 & 5.099 & $\mathrm{H}$ & 5.404 & -3.220 & 1.939 \\
\hline $\mathrm{C}$ & -3.957 & -4.248 & -0.242 & $\mathrm{~N}$ & 3.669 & -3.236 & 0.757 \\
\hline $\mathrm{H}$ & -3.808 & -3.829 & -1.241 & $\mathrm{C}$ & 3.128 & -2.007 & 0.377 \\
\hline $\mathrm{H}$ & -4.960 & -4.689 & -0.167 & $\mathrm{O}$ & 2.728 & -1.709 & -0.729 \\
\hline C & -3.976 & -5.539 & 2.982 & $\mathrm{~N}$ & 3.186 & -1.163 & 1.485 \\
\hline $\mathrm{H}$ & -3.853 & -5.878 & 4.014 & C & 3.831 & -1.779 & 2.623 \\
\hline $\mathrm{H}$ & -5.009 & -5.708 & 2.652 & $\mathrm{H}$ & 4.662 & -1.146 & 2.968 \\
\hline $\mathrm{N}$ & -3.086 & -6.345 & 2.173 & $\mathrm{~N}$ & 2.994 & -2.150 & 3.752 \\
\hline $\mathrm{C}$ & -3.151 & -6.486 & 0.736 & $\mathrm{C}$ & 3.142 & -3.497 & 4.087 \\
\hline $\mathrm{H}$ & -4.093 & -6.978 & 0.451 & $\mathrm{O}$ & 2.745 & -4.034 & 5.100 \\
\hline $\mathrm{N}$ & -2.958 & -5.289 & -0.066 & C & 2.462 & 0.090 & 1.505 \\
\hline $\mathrm{C}$ & -1.938 & -5.451 & -1.004 & $\mathrm{H}$ & 2.359 & 0.409 & 0.465 \\
\hline $\mathrm{O}$ & -1.696 & -4.717 & -1.939 & $\mathrm{H}$ & 3.046 & 0.830 & 2.067 \\
\hline $\mathrm{N}$ & -1.281 & -6.644 & -0.705 & $\mathrm{C}$ & 2.455 & -1.210 & 4.721 \\
\hline $\mathrm{C}$ & -1.884 & -7.352 & 0.402 & $\mathrm{H}$ & 3.132 & -0.350 & 4.810 \\
\hline $\mathrm{H}$ & -2.137 & -8.378 & 0.096 & $\mathrm{H}$ & 2.393 & -1.736 & 5.676 \\
\hline
\end{tabular}




\begin{tabular}{|c|c|c|c|c|c|c|c|}
\hline \multicolumn{8}{|c|}{ CB[5]-H ${ }^{+} \_N 2$} \\
\hline $\mathrm{O}$ & -0.092 & 0.144 & -0.015 & $\mathrm{C}$ & -1.519 & -7.108 & 2.922 \\
\hline $\mathrm{C}$ & -0.043 & 0.073 & 1.184 & $\mathrm{O}$ & -1.290 & -7.134 & 4.113 \\
\hline $\mathrm{N}$ & 1.097 & -0.043 & 1.988 & $\mathrm{C}$ & 0.512 & -7.116 & -1.082 \\
\hline $\mathrm{C}$ & 0.788 & 0.244 & 3.368 & $\mathrm{H}$ & 0.627 & -8.200 & -1.205 \\
\hline $\mathrm{H}$ & 1.105 & 1.258 & 3.650 & $\mathrm{H}$ & 0.507 & -6.631 & -2.061 \\
\hline $\mathrm{N}$ & 1.279 & -0.690 & 4.379 & $\mathrm{C}$ & 0.556 & -8.242 & 2.210 \\
\hline $\mathrm{C}$ & 0.327 & -1.432 & 4.989 & $\mathrm{H}$ & 0.538 & -8.461 & 3.280 \\
\hline $\mathrm{O}$ & 0.308 & -2.095 & 5.979 & $\mathrm{H}$ & 0.604 & -9.178 & 1.640 \\
\hline $\mathrm{N}$ & -0.935 & -1.290 & 4.082 & $\mathrm{~N}$ & 1.755 & -7.473 & 1.954 \\
\hline $\mathrm{C}$ & -0.758 & 0.078 & 3.410 & $\mathrm{C}$ & 2.391 & -7.312 & 0.664 \\
\hline $\mathrm{H}$ & -1.261 & 0.794 & 4.067 & $\mathrm{H}$ & 2.701 & -8.291 & 0.274 \\
\hline $\mathrm{N}$ & -1.161 & 0.135 & 2.059 & $\mathrm{~N}$ & 1.647 & -6.583 & -0.350 \\
\hline $\mathrm{C}$ & -2.505 & -0.189 & 1.582 & $\mathrm{C}$ & 2.360 & -5.490 & -0.842 \\
\hline $\mathrm{H}$ & -2.514 & 0.066 & 0.519 & $\mathrm{O}$ & 2.081 & -4.825 & -1.815 \\
\hline $\mathrm{H}$ & -3.234 & 0.425 & 2.121 & $\mathrm{~N}$ & 3.487 & -5.332 & -0.031 \\
\hline $\mathrm{C}$ & -2.291 & -1.595 & 4.779 & $\mathrm{C}$ & 3.604 & -6.363 & 0.975 \\
\hline $\mathrm{H}$ & -2.766 & -0.629 & 4.962 & $\mathrm{H}$ & 4.576 & -6.869 & 0.890 \\
\hline $\mathrm{H}$ & -2.028 & -2.096 & 5.715 & $\mathrm{~N}$ & 3.370 & -5.964 & 2.353 \\
\hline $\mathrm{N}$ & -3.079 & -2.467 & 4.003 & $\mathrm{C}$ & 2.342 & -6.700 & 2.949 \\
\hline $\mathrm{C}$ & -3.721 & -2.141 & 2.737 & $\mathrm{O}$ & 2.046 & -6.690 & 4.125 \\
\hline $\mathrm{H}$ & -4.584 & -1.485 & 2.905 & $\mathrm{C}$ & 4.321 & -4.158 & -0.131 \\
\hline $\mathrm{N}$ & -2.842 & -1.601 & 1.712 & $\mathrm{H}$ & 4.177 & -3.756 & -1.137 \\
\hline $\mathrm{C}$ & -2.905 & -2.384 & 0.530 & $\mathrm{H}$ & 5.371 & -4.439 & 0.009 \\
\hline $\mathrm{O}$ & -2.461 & -2.050 & -0.543 & $\mathrm{C}$ & 4.324 & -5.246 & 3.171 \\
\hline $\mathrm{N}$ & -3.585 & -3.547 & 0.837 & $\mathrm{H}$ & 4.184 & -5.575 & 4.204 \\
\hline $\mathrm{C}$ & -4.125 & -3.557 & 2.178 & $\mathrm{H}$ & 5.343 & -5.480 & 2.841 \\
\hline $\mathrm{H}$ & -5.212 & -3.708 & 2.149 & $\mathrm{~N}$ & 4.153 & -3.801 & 3.170 \\
\hline $\mathrm{N}$ & -3.528 & -4.491 & 3.128 & $\mathrm{C}$ & 4.599 & -2.903 & 2.116 \\
\hline $\mathrm{C}$ & -2.962 & -3.867 & 4.213 & $\mathrm{H}$ & 5.694 & -2.935 & 2.037 \\
\hline $\mathrm{O}$ & -2.461 & -4.360 & 5.198 & $\mathrm{~N}$ & 3.997 & -3.086 & 0.809 \\
\hline $\mathrm{C}$ & -3.630 & -4.659 & -0.109 & $\mathrm{C}$ & 3.241 & -1.994 & 0.409 \\
\hline $\mathrm{H}$ & -3.492 & -4.228 & -1.104 & $\mathrm{O}$ & 2.704 & -1.826 & -0.664 \\
\hline $\mathrm{H}$ & -4.615 & -5.136 & -0.044 & $\mathrm{~N}$ & 3.240 & -1.076 & 1.467 \\
\hline $\mathrm{C}$ & -3.693 & -5.951 & 3.098 & $\mathrm{C}$ & 4.062 & -1.494 & 2.581 \\
\hline $\mathrm{H}$ & -3.606 & -6.295 & 4.131 & $\mathrm{H}$ & 4.864 & -0.767 & 2.764 \\
\hline $\mathrm{H}$ & -4.693 & -6.179 & 2.714 & $\mathrm{~N}$ & 3.374 & -1.802 & 3.825 \\
\hline $\mathrm{N}$ & -2.704 & -6.658 & 2.330 & $\mathrm{C}$ & 3.453 & -3.161 & 4.170 \\
\hline $\mathrm{C}$ & -2.715 & -6.838 & 0.894 & $\mathrm{O}$ & 3.002 & -3.640 & 5.190 \\
\hline $\mathrm{H}$ & -3.602 & -7.411 & 0.591 & $\mathrm{C}$ & 2.436 & 0.111 & 1.398 \\
\hline $\mathrm{N}$ & -2.587 & -5.639 & 0.085 & $\mathrm{H}$ & 2.278 & 0.343 & 0.342 \\
\hline $\mathrm{C}$ & -1.504 & -5.711 & -0.800 & $\mathrm{H}$ & 2.955 & 0.945 & 1.888 \\
\hline $\mathrm{O}$ & -1.273 & -4.937 & -1.704 & $\mathrm{C}$ & 2.721 & -0.879 & 4.699 \\
\hline $\mathrm{N}$ & -0.779 & -6.850 & -0.473 & $\mathrm{H}$ & 3.201 & 0.103 & 4.662 \\
\hline $\mathrm{C}$ & -1.368 & -7.600 & 0.615 & $\mathrm{H}$ & 2.760 & -1.278 & 5.715 \\
\hline $\mathrm{H}$ & -1.522 & -8.645 & 0.313 & $\mathrm{H}$ & -0.826 & -2.008 & 3.353 \\
\hline
\end{tabular}




\begin{tabular}{|c|c|c|c|c|c|c|c|}
\hline \multicolumn{8}{|c|}{$\mathrm{CB}[5]-\mathrm{H}^{+} \_\mathrm{N} 4$} \\
\hline $\mathrm{O}$ & 0.119 & -0.517 & 0.093 & $\mathrm{C}$ & -1.414 & -7.213 & 2.891 \\
\hline $\mathrm{C}$ & 0.067 & -0.304 & 1.275 & $\mathrm{O}$ & -1.133 & -7.272 & 4.069 \\
\hline $\mathrm{N}$ & 1.190 & -0.082 & 2.118 & $\mathrm{C}$ & 0.479 & -7.091 & -1.122 \\
\hline $\mathrm{C}$ & 0.783 & 0.462 & 3.362 & $\mathrm{H}$ & 0.624 & -8.165 & -1.292 \\
\hline $\mathrm{H}$ & 1.040 & 1.523 & 3.480 & $\mathrm{H}$ & 0.462 & -6.564 & -2.080 \\
\hline $\mathrm{N}$ & 1.300 & -0.234 & 4.630 & $\mathrm{C}$ & 0.585 & -8.414 & 2.069 \\
\hline $\mathrm{C}$ & 0.147 & -1.136 & 5.172 & $\mathrm{H}$ & 0.582 & -8.717 & 3.119 \\
\hline $\mathrm{O}$ & 0.325 & -1.798 & 6.152 & $\mathrm{H}$ & 0.621 & -9.301 & 1.427 \\
\hline $\mathrm{N}$ & -0.924 & -0.878 & 4.405 & $\mathrm{~N}$ & 1.791 & -7.632 & 1.863 \\
\hline $\mathrm{C}$ & -0.764 & 0.189 & 3.405 & $\mathrm{C}$ & 2.395 & -7.341 & 0.579 \\
\hline $\mathrm{H}$ & -1.343 & 1.063 & 3.731 & $\mathrm{H}$ & 2.740 & -8.272 & 0.109 \\
\hline $\mathrm{N}$ & -1.075 & -0.164 & 2.056 & $\mathrm{~N}$ & 1.607 & -6.567 & -0.366 \\
\hline $\mathrm{C}$ & -2.423 & -0.256 & 1.475 & $\mathrm{C}$ & 2.270 & -5.419 & -0.790 \\
\hline $\mathrm{H}$ & -2.328 & -0.002 & 0.416 & $\mathrm{O}$ & 1.948 & -4.687 & -1.701 \\
\hline $\mathrm{H}$ & -3.053 & 0.486 & 1.980 & $\mathrm{~N}$ & 3.413 & -5.283 & 0.001 \\
\hline $\mathrm{C}$ & -2.248 & -1.468 & 4.750 & $\mathrm{C}$ & 3.575 & -6.367 & 0.943 \\
\hline $\mathrm{H}$ & -2.959 & -0.639 & 4.843 & $\mathrm{H}$ & 4.566 & -6.829 & 0.826 \\
\hline $\mathrm{H}$ & -2.113 & -1.961 & 5.716 & $\mathrm{~N}$ & 3.324 & -6.066 & 2.343 \\
\hline $\mathrm{N}$ & -2.719 & -2.431 & 3.813 & $\mathrm{C}$ & 2.348 & -6.896 & 2.901 \\
\hline $\mathrm{C}$ & -3.618 & -2.157 & 2.705 & $\mathrm{O}$ & 2.078 & -6.978 & 4.080 \\
\hline $\mathrm{H}$ & -4.475 & -1.564 & 3.054 & $\mathrm{C}$ & 4.261 & -4.123 & -0.114 \\
\hline $\mathrm{N}$ & -3.024 & -1.556 & 1.536 & $\mathrm{H}$ & 4.123 & -3.718 & -1.119 \\
\hline $\mathrm{C}$ & -3.062 & -2.395 & 0.411 & $\mathrm{H}$ & 5.307 & -4.422 & 0.026 \\
\hline $\mathrm{O}$ & -2.726 & -2.084 & -0.710 & $\mathrm{C}$ & 4.181 & -5.281 & 3.191 \\
\hline $\mathrm{N}$ & -3.605 & -3.602 & 0.825 & $\mathrm{H}$ & 4.010 & -5.611 & 4.219 \\
\hline $\mathrm{C}$ & -4.023 & -3.594 & 2.212 & $\mathrm{H}$ & 5.234 & -5.433 & 2.921 \\
\hline $\mathrm{H}$ & -5.104 & -3.779 & 2.280 & $\mathrm{~N}$ & 3.910 & -3.844 & 3.151 \\
\hline $\mathrm{N}$ & -3.320 & -4.482 & 3.124 & $\mathrm{C}$ & 4.460 & -2.935 & 2.163 \\
\hline $\mathrm{C}$ & -2.626 & -3.804 & 4.107 & $\mathrm{H}$ & 5.556 & -3.019 & 2.160 \\
\hline $\mathrm{O}$ & -2.062 & -4.263 & 5.078 & $\mathrm{~N}$ & 3.943 & -3.038 & 0.814 \\
\hline $\mathrm{C}$ & -3.699 & -4.741 & -0.074 & $\mathrm{C}$ & 3.386 & -1.848 & 0.365 \\
\hline $\mathrm{H}$ & -3.630 & -4.341 & -1.089 & $\mathrm{O}$ & 3.023 & -1.579 & -0.755 \\
\hline $\mathrm{H}$ & -4.670 & -5.231 & 0.068 & $\mathrm{~N}$ & 3.371 & -0.959 & 1.462 \\
\hline $\mathrm{C}$ & -3.500 & -5.932 & 3.178 & $\mathrm{C}$ & 3.960 & -1.528 & 2.640 \\
\hline $\mathrm{H}$ & -3.321 & -6.241 & 4.211 & $\mathrm{H}$ & 4.772 & -0.894 & 3.023 \\
\hline $\mathrm{H}$ & -4.534 & -6.161 & 2.896 & $\mathrm{~N}$ & 3.040 & -1.847 & 3.738 \\
\hline $\mathrm{N}$ & -2.590 & -6.688 & 2.356 & $\mathrm{C}$ & 3.138 & -3.227 & 4.102 \\
\hline $\mathrm{C}$ & -2.702 & -6.893 & 0.925 & $\mathrm{O}$ & 2.652 & -3.695 & 5.106 \\
\hline $\mathrm{H}$ & -3.608 & -7.472 & 0.698 & $\mathrm{C}$ & 2.496 & 0.176 & 1.475 \\
\hline $\mathrm{N}$ & -2.639 & -5.713 & 0.084 & $\mathrm{H}$ & 2.303 & 0.434 & 0.430 \\
\hline $\mathrm{C}$ & -1.573 & -5.754 & -0.815 & $\mathrm{H}$ & 2.970 & 1.023 & 1.986 \\
\hline $\mathrm{O}$ & -1.375 & -4.976 & -1.723 & $\mathrm{C}$ & 2.717 & -0.920 & 4.737 \\
\hline $\mathrm{N}$ & -0.811 & -6.876 & -0.504 & $\mathrm{H}$ & 3.414 & -0.077 & 4.764 \\
\hline $\mathrm{C}$ & -1.377 & -7.666 & 0.569 & $\mathrm{H}$ & 2.648 & -1.421 & 5.708 \\
\hline $\mathrm{H}$ & -1.563 & -8.692 & 0.223 & $\mathrm{H}$ & 1.363 & 0.496 & 5.349 \\
\hline $\mathrm{N}$ & -0.653 & -7.693 & 1.829 & & & & \\
\hline
\end{tabular}




\begin{tabular}{|c|c|c|c|c|c|c|c|}
\hline \multicolumn{8}{|c|}{$\mathrm{CB}[5] \mathrm{A}$} \\
\hline $\mathrm{C}$ & -0.008 & 0.314 & -0.001 & $\mathrm{H}$ & -3.852 & 7.684 & 0.780 \\
\hline $\mathrm{N}$ & 0.011 & 0.190 & 1.441 & $\mathrm{~N}$ & -3.114 & 5.967 & -0.198 \\
\hline $\mathrm{C}$ & 1.366 & 0.027 & 1.951 & $\mathrm{C}$ & -3.520 & 4.633 & 0.194 \\
\hline $\mathrm{H}$ & 1.469 & -0.946 & 2.455 & $\mathrm{~N}$ & -4.106 & 4.811 & 1.523 \\
\hline $\mathrm{N}$ & 1.892 & 1.059 & 2.848 & $\mathrm{C}$ & -3.443 & 5.963 & 2.138 \\
\hline $\mathrm{C}$ & 2.365 & 2.159 & 2.008 & $\mathrm{H}$ & -4.144 & 6.414 & 2.857 \\
\hline $\mathrm{N}$ & 2.767 & 1.516 & 0.776 & $\mathrm{~N}$ & -2.143 & 5.751 & 2.763 \\
\hline $\mathrm{C}$ & 2.244 & 0.160 & 0.677 & $\mathrm{C}$ & -1.109 & 6.543 & 2.130 \\
\hline $\mathrm{H}$ & 3.069 & -0.566 & 0.634 & $\mathrm{C}$ & -4.224 & 3.585 & 2.313 \\
\hline $\mathrm{N}$ & 1.318 & -0.144 & -0.417 & $\mathrm{H}$ & -4.914 & 2.928 & 1.763 \\
\hline $\mathrm{C}$ & 1.707 & 0.247 & -1.772 & $\mathrm{H}$ & -4.712 & 3.854 & 3.259 \\
\hline $\mathrm{H}$ & 0.995 & -0.242 & -2.453 & $\mathrm{C}$ & -2.010 & 5.283 & 4.126 \\
\hline $\mathrm{H}$ & 2.696 & -0.190 & -1.964 & $\mathrm{H}$ & -1.308 & 5.939 & 4.662 \\
\hline $\mathrm{C}$ & 3.923 & 1.959 & 0.027 & $\mathrm{H}$ & -2.983 & 5.365 & 4.628 \\
\hline $\mathrm{H}$ & 4.441 & 1.080 & -0.380 & $\mathrm{~N}$ & -1.534 & 3.915 & 4.328 \\
\hline $\mathrm{H}$ & 4.621 & 2.461 & 0.713 & $\mathrm{C}$ & -2.419 & 2.816 & 3.934 \\
\hline $\mathrm{N}$ & 3.700 & 2.883 & -1.085 & $\mathrm{H}$ & -3.205 & 2.725 & 4.699 \\
\hline $\mathrm{C}$ & 3.007 & 2.376 & -2.271 & $\mathrm{~N}$ & -3.011 & 2.854 & 2.603 \\
\hline $\mathrm{H}$ & 3.716 & 1.757 & -2.840 & $\mathrm{C}$ & -2.588 & 1.729 & 1.797 \\
\hline $\mathrm{N}$ & 1.752 & 1.661 & -2.076 & $\mathrm{~N}$ & -2.013 & 0.792 & 2.761 \\
\hline $\mathrm{C}$ & 0.647 & 2.329 & -2.731 & $\mathrm{C}$ & -1.475 & 1.586 & 3.868 \\
\hline $\mathrm{N}$ & 1.287 & 3.296 & -3.623 & $\mathrm{H}$ & -1.499 & 0.964 & 4.775 \\
\hline $\mathrm{C}$ & 2.570 & 3.663 & -3.020 & $\mathrm{~N}$ & -0.157 & 2.186 & 3.701 \\
\hline $\mathrm{H}$ & 3.256 & 3.952 & -3.831 & $\mathrm{C}$ & -0.213 & 3.631 & 3.767 \\
\hline $\mathrm{N}$ & 2.569 & 4.675 & -1.972 & C & -1.154 & -0.241 & 2.182 \\
\hline $\mathrm{C}$ & 3.057 & 4.144 & -0.717 & $\mathrm{H}$ & -1.795 & -0.845 & 1.523 \\
\hline C & 0.419 & 4.376 & -4.091 & $\mathrm{H}$ & -0.829 & -0.890 & 3.006 \\
\hline $\mathrm{H}$ & -0.382 & 3.900 & -4.677 & $\mathrm{C}$ & 1.063 & 1.462 & 3.984 \\
\hline $\mathrm{H}$ & 1.009 & 4.990 & -4.785 & $\mathrm{H}$ & 0.815 & 0.550 & 4.543 \\
\hline $\mathrm{C}$ & 2.613 & 6.091 & -2.265 & $\mathrm{H}$ & 1.704 & 2.079 & 4.632 \\
\hline $\mathrm{H}$ & 3.403 & 6.558 & -1.658 & $\mathrm{H}$ & -4.268 & 4.222 & -0.504 \\
\hline $\mathrm{H}$ & 2.886 & 6.229 & -3.319 & $\mathrm{H}$ & -2.663 & 3.937 & 0.219 \\
\hline $\mathrm{N}$ & 1.397 & 6.869 & -2.028 & $\mathrm{H}$ & -3.445 & 1.268 & 1.276 \\
\hline C & 0.244 & 6.619 & -2.897 & $\mathrm{H}$ & -1.850 & 2.028 & 1.032 \\
\hline $\mathrm{H}$ & 0.440 & 7.102 & -3.865 & $\mathrm{H}$ & -0.792 & -0.320 & -0.446 \\
\hline $\mathrm{N}$ & -0.179 & 5.239 & -3.096 & $\mathrm{H}$ & -0.194 & 1.355 & -0.320 \\
\hline C & -1.517 & 5.011 & -2.597 & $\mathrm{H}$ & -0.020 & 2.825 & -2.004 \\
\hline $\mathrm{N}$ & -2.069 & 6.354 & -2.423 & $\mathrm{H}$ & 0.037 & 1.617 & -3.313 \\
\hline $\mathrm{C}$ & -0.946 & 7.246 & -2.121 & $\mathrm{H}$ & -1.510 & 4.451 & -1.645 \\
\hline $\mathrm{H}$ & -1.211 & 8.256 & -2.467 & $\mathrm{H}$ & -2.120 & 4.437 & -3.320 \\
\hline $\mathrm{N}$ & -0.461 & 7.294 & -0.747 & $\mathrm{H}$ & 2.236 & 3.985 & 0.004 \\
\hline C & 0.912 & 6.850 & -0.648 & $\mathrm{H}$ & 3.787 & 4.828 & -0.252 \\
\hline $\mathrm{C}$ & -3.250 & 6.428 & -1.562 & $\mathrm{H}$ & 3.216 & 2.672 & 2.486 \\
\hline $\mathrm{H}$ & -3.580 & 7.475 & -1.554 & $\mathrm{H}$ & 1.572 & 2.908 & 1.839 \\
\hline $\mathrm{H}$ & -4.035 & 5.841 & -2.062 & $\mathrm{H}$ & 0.578 & 4.031 & 4.423 \\
\hline $\mathrm{C}$ & -1.058 & 8.147 & 0.256 & $\mathrm{H}$ & -0.088 & 4.090 & 2.770 \\
\hline $\mathrm{H}$ & -0.263 & 8.716 & 0.761 & $\mathrm{H}$ & -0.492 & 7.066 & 2.880 \\
\hline $\mathrm{H}$ & -1.714 & 8.874 & -0.241 & $\mathrm{H}$ & -0.437 & 5.919 & 1.517 \\
\hline $\mathrm{N}$ & -1.844 & 7.508 & 1.312 & $\mathrm{H}$ & 0.984 & 5.840 & -0.207 \\
\hline C & -3.113 & 6.884 & 0.935 & $\mathrm{H}$ & 1.508 & 7.534 & -0.021 \\
\hline
\end{tabular}




\begin{tabular}{|c|c|c|c|c|c|c|c|}
\hline \multicolumn{8}{|c|}{ CB[5]A-H ${ }^{+}$N2 } \\
\hline $\mathrm{C}$ & 0.022 & -0.103 & 0.004 & $\mathrm{~N}$ & -3.442 & 5.384 & -0.725 \\
\hline $\mathrm{N}$ & 0.027 & -0.035 & 1.449 & $\mathrm{C}$ & -3.744 & 4.032 & -0.229 \\
\hline $\mathrm{C}$ & 1.383 & -0.013 & 1.987 & $\mathrm{~N}$ & -4.413 & 4.249 & 1.047 \\
\hline $\mathrm{H}$ & 1.570 & -0.913 & 2.591 & $\mathrm{C}$ & -3.924 & 5.498 & 1.598 \\
\hline $\mathrm{N}$ & 1.789 & 1.152 & 2.776 & $\mathrm{H}$ & -4.690 & 5.912 & 2.273 \\
\hline $\mathrm{C}$ & 2.199 & 2.198 & 1.844 & $\mathrm{~N}$ & -2.592 & 5.491 & 2.239 \\
\hline $\mathrm{N}$ & 2.667 & 1.478 & 0.680 & $\mathrm{C}$ & -1.927 & 6.749 & 1.933 \\
\hline C & 2.270 & 0.073 & 0.718 & $\mathrm{C}$ & -4.478 & 3.059 & 1.915 \\
\hline $\mathrm{H}$ & 3.159 & -0.572 & 0.762 & $\mathrm{H}$ & -5.091 & 2.323 & 1.376 \\
\hline $\mathrm{N}$ & 1.402 & -0.421 & -0.351 & $\mathrm{H}$ & -5.036 & 3.351 & 2.814 \\
\hline $\mathrm{C}$ & 1.769 & -0.109 & -1.726 & $\mathrm{C}$ & -2.518 & 5.083 & 3.665 \\
\hline $\mathrm{H}$ & 1.120 & -0.714 & -2.375 & $\mathrm{H}$ & -1.934 & 5.843 & 4.199 \\
\hline $\mathrm{H}$ & 2.798 & -0.455 & -1.882 & $\mathrm{H}$ & -3.526 & 5.090 & 4.103 \\
\hline $\mathrm{C}$ & 3.807 & 1.934 & -0.083 & $\mathrm{~N}$ & -1.920 & 3.802 & 3.943 \\
\hline $\mathrm{H}$ & 4.392 & 1.065 & -0.410 & $\mathrm{C}$ & -2.679 & 2.593 & 3.635 \\
\hline $\mathrm{H}$ & 4.460 & 2.543 & 0.559 & $\mathrm{H}$ & -3.477 & 2.486 & 4.383 \\
\hline $\mathrm{N}$ & 3.531 & 2.740 & -1.279 & $\mathrm{~N}$ & -3.223 & 2.466 & 2.287 \\
\hline C & 2.871 & 2.079 & -2.406 & C & -2.696 & 1.293 & 1.609 \\
\hline $\mathrm{H}$ & 3.624 & 1.471 & -2.927 & $\mathrm{~N}$ & -2.061 & 0.523 & 2.674 \\
\hline $\mathrm{N}$ & 1.679 & 1.284 & -2.133 & C & -1.619 & 1.470 & 3.696 \\
\hline $\mathrm{C}$ & 0.524 & 1.785 & -2.840 & $\mathrm{H}$ & -1.595 & 0.944 & 4.661 \\
\hline $\mathrm{N}$ & 1.077 & 2.738 & -3.801 & $\mathrm{~N}$ & -0.363 & 2.181 & 3.468 \\
\hline $\mathrm{C}$ & 2.332 & 3.251 & -3.261 & $\mathrm{C}$ & -0.549 & 3.616 & 3.473 \\
\hline $\mathrm{H}$ & 2.988 & 3.521 & -4.101 & C & -1.106 & -0.493 & 2.223 \\
\hline $\mathrm{N}$ & 2.253 & 4.356 & -2.303 & $\mathrm{H}$ & -1.679 & -1.219 & 1.631 \\
\hline C & 2.838 & 3.995 & -1.021 & $\mathrm{H}$ & -0.745 & -1.016 & 3.118 \\
\hline C & 0.136 & 3.662 & -4.381 & C & 0.911 & 1.594 & 3.853 \\
\hline $\mathrm{H}$ & -0.600 & 3.077 & -4.945 & $\mathrm{H}$ & 0.725 & 0.728 & 4.500 \\
\hline $\mathrm{H}$ & 0.674 & 4.288 & -5.106 & $\mathrm{H}$ & 1.478 & 2.326 & 4.445 \\
\hline $\mathrm{C}$ & 2.164 & 5.722 & -2.731 & $\mathrm{H}$ & -4.408 & 3.497 & -0.923 \\
\hline $\mathrm{H}$ & 2.888 & 6.339 & -2.184 & $\mathrm{H}$ & -2.817 & 3.450 & -0.117 \\
\hline $\mathrm{H}$ & 2.403 & 5.806 & -3.798 & $\mathrm{H}$ & -3.502 & 0.707 & 1.138 \\
\hline $\mathrm{N}$ & 0.844 & 6.374 & -2.542 & $\mathrm{H}$ & -1.973 & 1.573 & 0.823 \\
\hline C & -0.261 & 5.957 & -3.399 & $\mathrm{H}$ & -0.660 & -0.891 & -0.358 \\
\hline $\mathrm{H}$ & -0.078 & 6.370 & -4.403 & $\mathrm{H}$ & -0.303 & 0.853 & -0.447 \\
\hline $\mathrm{N}$ & -0.607 & 4.534 & -3.441 & $\mathrm{H}$ & -0.199 & 2.280 & -2.163 \\
\hline C & -2.058 & 4.374 & -3.398 & $\mathrm{H}$ & -0.009 & 0.976 & -3.366 \\
\hline $\mathrm{N}$ & -2.579 & 5.698 & -3.006 & $\mathrm{H}$ & -2.344 & 3.599 & -2.672 \\
\hline C & -1.493 & 6.568 & -2.734 & $\mathrm{H}$ & -2.481 & 4.090 & -4.376 \\
\hline $\mathrm{H}$ & -1.683 & 7.612 & -2.993 & $\mathrm{H}$ & 2.062 & 3.878 & -0.243 \\
\hline $\mathrm{N}$ & -1.079 & 6.565 & -1.214 & $\mathrm{H}$ & 3.548 & 4.765 & -0.676 \\
\hline $\mathrm{C}$ & 0.404 & 6.360 & -1.157 & $\mathrm{H}$ & 3.002 & 2.813 & 2.284 \\
\hline C & -3.745 & 5.732 & -2.118 & $\mathrm{H}$ & 1.355 & 2.871 & 1.599 \\
\hline $\mathrm{H}$ & -4.166 & 6.744 & -2.151 & $\mathrm{H}$ & 0.160 & 4.113 & 4.156 \\
\hline $\mathrm{H}$ & -4.495 & 5.051 & -2.535 & $\mathrm{H}$ & -0.411 & 4.054 & 2.466 \\
\hline C & -1.737 & 7.710 & -0.354 & $\mathrm{H}$ & -2.068 & 7.511 & 2.722 \\
\hline $\mathrm{H}$ & -0.922 & 8.324 & 0.031 & $\mathrm{H}$ & -0.843 & 6.600 & 1.813 \\
\hline $\mathrm{H}$ & -2.321 & 8.300 & -1.065 & $\mathrm{H}$ & 0.578 & 5.403 & -0.652 \\
\hline $\mathrm{N}$ & -2.547 & 7.212 & 0.683 & $\mathrm{H}$ & 0.878 & 7.166 & -0.588 \\
\hline C & -3.702 & 6.368 & 0.344 & $\mathrm{H}$ & -1.578 & 5.731 & -0.852 \\
\hline $\mathrm{H}$ & -4.565 & 6.998 & 0.094 & & & & \\
\hline
\end{tabular}




\begin{tabular}{|c|c|c|c|c|c|c|c|}
\hline \multicolumn{8}{|c|}{ CB[5]A-H ${ }^{+} \_N 4$} \\
\hline $\mathrm{C}$ & -0.032 & 0.000 & 0.004 & $\mathrm{~N}$ & -3.510 & 5.261 & -0.721 \\
\hline $\mathrm{N}$ & -0.020 & 0.017 & 1.449 & $\mathrm{C}$ & -3.881 & 3.951 & -0.200 \\
\hline $\mathrm{C}$ & 1.337 & -0.008 & 1.982 & $\mathrm{~N}$ & -4.478 & 4.232 & 1.102 \\
\hline $\mathrm{H}$ & 1.506 & -0.930 & 2.556 & $\mathrm{C}$ & -3.915 & 5.484 & 1.592 \\
\hline $\mathrm{N}$ & 1.774 & 1.121 & 2.806 & $\mathrm{H}$ & -4.652 & 5.952 & 2.262 \\
\hline $\mathrm{C}$ & 2.203 & 2.187 & 1.910 & $\mathrm{~N}$ & -2.596 & 5.448 & 2.226 \\
\hline $\mathrm{N}$ & 2.639 & 1.496 & 0.713 & $\mathrm{C}$ & -1.665 & 6.345 & 1.582 \\
\hline $\mathrm{C}$ & 2.221 & 0.097 & 0.713 & $\mathrm{C}$ & -4.525 & 3.087 & 2.018 \\
\hline $\mathrm{H}$ & 3.099 & -0.564 & 0.734 & $\mathrm{H}$ & -5.167 & 2.333 & 1.541 \\
\hline $\mathrm{N}$ & 1.339 & -0.347 & -0.366 & $\mathrm{H}$ & -5.038 & 3.422 & 2.928 \\
\hline $\mathrm{C}$ & 1.717 & -0.047 & -1.735 & $\mathrm{C}$ & -2.452 & 5.121 & 3.641 \\
\hline $\mathrm{H}$ & 1.073 & -0.650 & -2.389 & $\mathrm{H}$ & -1.818 & 5.884 & 4.115 \\
\hline $\mathrm{H}$ & 2.747 & -0.399 & -1.880 & $\mathrm{H}$ & -3.438 & 5.177 & 4.121 \\
\hline $\mathrm{C}$ & 3.763 & 1.962 & -0.054 & $\mathrm{~N}$ & -1.878 & 3.826 & 3.973 \\
\hline $\mathrm{H}$ & 4.355 & 1.108 & -0.405 & $\mathrm{C}$ & -2.673 & 2.625 & 3.700 \\
\hline $\mathrm{H}$ & 4.417 & 2.574 & 0.583 & $\mathrm{H}$ & -3.450 & 2.550 & 4.474 \\
\hline $\mathrm{N}$ & 3.459 & 2.785 & -1.239 & $\mathrm{~N}$ & -3.263 & 2.486 & 2.375 \\
\hline C & 2.845 & 2.128 & -2.394 & $\mathrm{C}$ & -2.746 & 1.330 & 1.675 \\
\hline $\mathrm{H}$ & 3.618 & 1.522 & -2.889 & $\mathrm{~N}$ & -2.093 & 0.542 & 2.716 \\
\hline $\mathrm{N}$ & 1.630 & 1.352 & -2.164 & $\mathrm{C}$ & -1.635 & 1.473 & 3.751 \\
\hline C & 0.548 & 1.768 & -3.035 & $\mathrm{H}$ & -1.624 & 0.936 & 4.710 \\
\hline $\mathrm{N}$ & 1.130 & 2.827 & -3.869 & $\mathrm{~N}$ & -0.364 & 2.156 & 3.540 \\
\hline C & 2.350 & 3.308 & -3.264 & $\mathrm{C}$ & -0.529 & 3.590 & 3.465 \\
\hline $\mathrm{H}$ & 3.058 & 3.603 & -4.050 & $\mathrm{C}$ & -1.151 & -0.459 & 2.223 \\
\hline $\mathrm{N}$ & 2.239 & 4.409 & -2.283 & $\mathrm{H}$ & -1.734 & -1.163 & 1.612 \\
\hline C & 2.658 & 3.965 & -0.957 & $\mathrm{H}$ & -0.778 & -1.016 & 3.092 \\
\hline C & 0.225 & 3.773 & -4.479 & $\mathrm{C}$ & 0.901 & 1.552 & 3.900 \\
\hline $\mathrm{H}$ & -0.518 & 3.203 & -5.049 & $\mathrm{H}$ & 0.711 & 0.675 & 4.531 \\
\hline $\mathrm{H}$ & 0.791 & 4.382 & -5.195 & $\mathrm{H}$ & 1.485 & 2.265 & 4.501 \\
\hline $\mathrm{C}$ & 2.262 & 5.745 & -2.660 & $\mathrm{H}$ & -4.612 & 3.451 & -0.856 \\
\hline $\mathrm{H}$ & 2.926 & 6.353 & -2.033 & $\mathrm{H}$ & -2.998 & 3.297 & -0.115 \\
\hline $\mathrm{H}$ & 2.541 & 5.874 & -3.712 & $\mathrm{H}$ & -3.558 & 0.752 & 1.205 \\
\hline $\mathrm{N}$ & 0.887 & 6.492 & -2.535 & $\mathrm{H}$ & -2.032 & 1.618 & 0.882 \\
\hline C & -0.284 & 6.069 & -3.514 & $\mathrm{H}$ & -0.737 & -0.755 & -0.384 \\
\hline $\mathrm{H}$ & -0.022 & 6.542 & -4.469 & $\mathrm{H}$ & -0.325 & 0.980 & -0.419 \\
\hline $\mathrm{N}$ & -0.498 & 4.687 & -3.583 & $\mathrm{H}$ & -0.317 & 2.130 & -2.454 \\
\hline C & -1.777 & 4.313 & -2.987 & $\mathrm{H}$ & 0.192 & 0.941 & -3.672 \\
\hline $\mathrm{N}$ & -2.507 & 5.571 & -2.947 & $\mathrm{H}$ & -1.649 & 3.869 & -1.986 \\
\hline C & -1.548 & 6.654 & -2.790 & $\mathrm{H}$ & -2.294 & 3.583 & -3.624 \\
\hline $\mathrm{H}$ & -1.956 & 7.549 & -3.275 & $\mathrm{H}$ & 1.784 & 3.735 & -0.325 \\
\hline $\mathrm{N}$ & -1.038 & 7.052 & -1.469 & $\mathrm{H}$ & 3.260 & 4.736 & -0.454 \\
\hline C & 0.220 & 6.440 & -1.187 & $\mathrm{H}$ & 3.028 & 2.763 & 2.362 \\
\hline $\mathrm{C}$ & -3.713 & 5.577 & -2.112 & $\mathrm{H}$ & 1.379 & 2.892 & 1.693 \\
\hline $\mathrm{H}$ & -4.169 & 6.571 & -2.213 & $\mathrm{H}$ & 0.215 & 4.112 & 4.090 \\
\hline $\mathrm{H}$ & -4.406 & 4.856 & -2.564 & $\mathrm{H}$ & -0.418 & 3.963 & 2.429 \\
\hline $\mathrm{C}$ & -1.793 & 7.792 & -0.441 & $\mathrm{H}$ & -1.203 & 7.045 & 2.300 \\
\hline $\mathrm{H}$ & -1.081 & 8.475 & 0.040 & $\mathrm{H}$ & -0.842 & 5.785 & 1.097 \\
\hline $\mathrm{H}$ & -2.525 & 8.406 & -0.978 & $\mathrm{H}$ & 0.199 & 5.381 & -0.899 \\
\hline $\mathrm{N}$ & -2.477 & 7.082 & 0.611 & $\mathrm{H}$ & 0.798 & 7.008 & -0.450 \\
\hline C & -3.662 & 6.294 & 0.303 & $\mathrm{H}$ & 1.069 & 7.481 & -2.734 \\
\hline $\mathrm{H}$ & -4.483 & 6.980 & 0.048 & & & & \\
\hline
\end{tabular}




\begin{tabular}{|c|c|c|c|c|c|c|c|c|c|c|c|}
\hline \multicolumn{12}{|c|}{ CB[6] } \\
\hline $\mathrm{O}$ & -0.054 & 0.035 & -0.001 & $\mathrm{~N}$ & -4.380 & -5.091 & 0.065 & $\mathrm{~N}$ & 3.146 & -7.932 & 1.717 \\
\hline C & -0.037 & 0.034 & 1.213 & C & -4.847 & -6.131 & 0.960 & C & 3.886 & -7.546 & 0.536 \\
\hline $\mathrm{N}$ & 1.096 & -0.035 & 2.024 & $\mathrm{H}$ & -5.942 & -6.226 & 0.882 & $\mathrm{H}$ & 4.539 & -8.373 & 0.216 \\
\hline C & 0.792 & 0.257 & 3.413 & $\mathrm{~N}$ & -4.460 & -6.028 & 2.350 & $\mathrm{~N}$ & 3.119 & -7.062 & -0.596 \\
\hline $\mathrm{H}$ & 1.235 & 1.224 & 3.697 & C & -3.630 & -7.067 & 2.760 & C & 3.455 & -5.755 & -0.944 \\
\hline $\mathrm{N}$ & 1.140 & -0.749 & 4.390 & $\mathrm{O}$ & -3.281 & -7.302 & 3.899 & $\mathrm{O}$ & 3.109 & -5.167 & -1.949 \\
\hline C & 0.028 & -1.375 & 4.945 & $\mathrm{~N}$ & -3.322 & -7.823 & 1.630 & $\mathrm{~N}$ & 4.306 & -5.268 & 0.044 \\
\hline $\mathrm{O}$ & 0.035 & -2.178 & 5.855 & C & -4.083 & -7.412 & 0.466 & C & 4.684 & -6.279 & 1.007 \\
\hline $\mathrm{N}$ & -1.099 & -0.863 & 4.302 & $\mathrm{H}$ & -4.757 & -8.225 & 0.156 & $\mathrm{H}$ & 5.776 & -6.424 & 0.987 \\
\hline C & -0.777 & 0.265 & 3.447 & $\mathrm{~N}$ & -3.335 & -6.932 & -0.676 & $\mathrm{~N}$ & 4.240 & -6.088 & 2.373 \\
\hline $\mathrm{H}$ & -1.195 & 1.189 & 3.875 & C & -3.563 & -5.587 & -0.949 & C & 3.404 & -7.113 & 2.812 \\
\hline $\mathrm{N}$ & -1.140 & 0.161 & 2.052 & $\mathrm{O}$ & -3.167 & -4.973 & -1.919 & $\mathrm{O}$ & 3.016 & -7.288 & 3.949 \\
\hline C & -2.428 & -1.138 & 4.815 & C & -2.615 & -9.084 & 1.744 & C & 4.863 & -3.935 & -0.026 \\
\hline $\mathrm{H}$ & -2.300 & -1.706 & 5.741 & $\mathrm{H}$ & -3.191 & -9.867 & 1.232 & $\mathrm{H}$ & 5.948 & -3.990 & 0.140 \\
\hline $\mathrm{H}$ & -2.939 & -0.187 & 5.025 & $\mathrm{H}$ & -2.543 & -9.311 & 2.811 & $\mathrm{H}$ & 4.658 & -3.560 & -1.032 \\
\hline C & -2.491 & 0.204 & 1.534 & C & -2.521 & -7.755 & -1.541 & C & 4.835 & -5.154 & 3.307 \\
\hline $\mathrm{H}$ & -3.043 & 1.003 & 2.048 & $\mathrm{H}$ & -2.379 & -7.195 & -2.469 & $\mathrm{H}$ & 4.615 & -5.523 & 4.312 \\
\hline $\mathrm{H}$ & -2.412 & 0.432 & 0.468 & $\mathrm{H}$ & -3.055 & -8.694 & -1.748 & $\mathrm{H}$ & 5.923 & -5.131 & 3.146 \\
\hline $\mathrm{N}$ & -3.236 & -1.035 & 1.644 & $\mathrm{~N}$ & -1.200 & -8.061 & -1.026 & $\mathrm{~N}$ & 4.318 & -3.805 & 3.235 \\
\hline C & -4.001 & -1.433 & 2.810 & C & -0.906 & -9.197 & -0.170 & C & 4.733 & -2.806 & 2.274 \\
\hline $\mathrm{H}$ & -4.653 & -0.605 & 3.127 & $\mathrm{H}$ & -1.349 & -10.110 & -0.598 & $\mathrm{H}$ & 5.828 & -2.693 & 2.301 \\
\hline $\mathrm{N}$ & -3.260 & -1.938 & 3.945 & $\mathrm{~N}$ & -1.265 & -9.083 & 1.225 & $\mathrm{~N}$ & 4.292 & -2.983 & 0.905 \\
\hline C & -3.532 & -3.274 & 4.221 & C & -0.157 & -8.988 & 2.062 & C & 3.478 & -1.941 & 0.466 \\
\hline $\mathrm{O}$ & -3.154 & -3.900 & 5.190 & $\mathrm{O}$ & -0.173 & -8.988 & 3.277 & $\mathrm{O}$ & 3.096 & -1.757 & -0.672 \\
\hline $\mathrm{N}$ & -4.368 & -3.744 & 3.209 & $\mathrm{~N}$ & 0.976 & -8.951 & 1.250 & $\mathrm{~N}$ & 3.234 & -1.117 & 1.561 \\
\hline C & -4.800 & -2.691 & 2.313 & C & 0.662 & -9.231 & -0.140 & C & 3.969 & -1.515 & 2.741 \\
\hline $\mathrm{H}$ & -5.892 & -2.565 & 2.385 & $\mathrm{H}$ & 1.079 & -10.209 & -0.426 & $\mathrm{H}$ & 4.645 & -0.703 & 3.053 \\
\hline $\mathrm{N}$ & -4.409 & -2.806 & 0.924 & $\mathrm{~N}$ & 1.036 & -8.233 & -1.115 & $\mathrm{~N}$ & 3.196 & -1.972 & 3.879 \\
\hline C & -3.557 & -1.785 & 0.514 & C & -0.061 & -7.578 & -1.668 & C & 3.486 & -3.291 & 4.225 \\
\hline $\mathrm{O}$ & -3.201 & -1.559 & -0.624 & $\mathrm{O}$ & -0.033 & -6.774 & -2.577 & $\mathrm{O}$ & 3.121 & -3.867 & 5.230 \\
\hline C & -4.978 & -5.056 & 3.288 & C & 2.390 & -7.916 & -1.513 & C & 2.423 & 0.074 & 1.448 \\
\hline $\mathrm{H}$ & -6.063 & -4.956 & 3.140 & $\mathrm{H}$ & 2.321 & -7.378 & -2.462 & $\mathrm{H}$ & 2.953 & 0.915 & 1.920 \\
\hline $\mathrm{H}$ & -4.772 & -5.444 & 4.289 & $\mathrm{H}$ & 2.947 & -8.853 & -1.653 & $\mathrm{H}$ & 2.293 & 0.269 & 0.380 \\
\hline C & -4.952 & -3.763 & -0.016 & C & 2.300 & -9.100 & 1.825 & C & 2.486 & -1.097 & 4.792 \\
\hline $\mathrm{H}$ & -4.733 & -3.380 & -1.016 & $\mathrm{H}$ & 2.806 & -9.953 & 1.350 & $\mathrm{H}$ & 2.403 & -1.629 & 5.743 \\
\hline $\mathrm{H}$ & -6.040 & -3.831 & 0.130 & $\mathrm{H}$ & 2.165 & -9.295 & 2.892 & $\mathrm{H}$ & 3.066 & -0.173 & 4.928 \\
\hline
\end{tabular}




\begin{tabular}{|c|c|c|c|c|c|c|c|c|c|c|c|}
\hline \multicolumn{12}{|c|}{$\mathrm{CB}[6]-\mathrm{H}^{+} \_\mathrm{N} 2$} \\
\hline $\mathrm{O}$ & -0.165 & 0.005 & -0.056 & $\mathrm{C}$ & -4.598 & -6.434 & 0.859 & $\mathrm{C}$ & 4.280 & -7.344 & 0.718 \\
\hline $\mathrm{C}$ & -0.088 & -0.022 & 1.145 & $\mathrm{C}$ & -3.381 & -7.377 & 2.663 & $\mathrm{H}$ & 4.946 & -8.196 & 0.514 \\
\hline $\mathrm{N}$ & 1.070 & -0.135 & 1.924 & $\mathrm{O}$ & -3.064 & -7.621 & 3.808 & $\mathrm{~N}$ & 3.615 & -6.933 & -0.503 \\
\hline C & 0.797 & 0.204 & 3.302 & $\mathrm{~N}$ & -3.048 & -8.103 & 1.529 & $\mathrm{C}$ & 3.941 & -5.635 & -0.882 \\
\hline $\mathrm{H}$ & 1.119 & 1.229 & 3.538 & $\mathrm{C}$ & -3.713 & -7.622 & 0.335 & $\mathrm{O}$ & 3.655 & -5.090 & -1.927 \\
\hline $\mathrm{N}$ & 1.320 & -0.692 & 4.330 & $\mathrm{H}$ & -4.303 & -8.432 & -0.118 & $\mathrm{~N}$ & 4.708 & -5.085 & 0.149 \\
\hline $\mathrm{C}$ & 0.399 & -1.479 & 4.929 & $\mathrm{~N}$ & -2.877 & -6.995 & -0.672 & $\mathrm{C}$ & 5.051 & -6.053 & 1.169 \\
\hline $\mathrm{O}$ & 0.414 & -2.170 & 5.901 & $\mathrm{C}$ & -3.230 & -5.676 & -0.920 & $\mathrm{H}$ & 6.142 & -6.192 & 1.211 \\
\hline $\mathrm{N}$ & -0.885 & -1.345 & 4.055 & $\mathrm{O}$ & -2.792 & -4.953 & -1.791 & $\mathrm{~N}$ & 4.532 & -5.799 & 2.497 \\
\hline $\mathrm{C}$ & -0.741 & 0.034 & 3.382 & $\mathrm{C}$ & -2.228 & -9.302 & 1.606 & $\mathrm{C}$ & 3.618 & -6.769 & 2.914 \\
\hline $\mathrm{H}$ & -1.232 & 0.741 & 4.056 & $\mathrm{H}$ & -2.702 & -10.093 & 1.013 & $\mathrm{O}$ & 3.119 & -6.846 & 4.019 \\
\hline $\mathrm{N}$ & -1.177 & 0.093 & 2.046 & $\mathrm{H}$ & -2.200 & -9.594 & 2.659 & $\mathrm{C}$ & 5.261 & -3.757 & 0.050 \\
\hline C & -2.205 & -1.640 & 4.803 & $\mathrm{C}$ & -1.992 & -7.717 & -1.568 & $\mathrm{H}$ & 6.335 & -3.780 & 0.275 \\
\hline $\mathrm{H}$ & -1.930 & -2.291 & 5.638 & $\mathrm{H}$ & -1.830 & -7.080 & -2.441 & $\mathrm{H}$ & 5.105 & -3.427 & -0.980 \\
\hline $\mathrm{H}$ & -2.571 & -0.673 & 5.160 & $\mathrm{H}$ & -2.483 & -8.652 & -1.876 & $\mathrm{C}$ & 5.072 & -4.835 & 3.420 \\
\hline C & -2.570 & 0.012 & 1.608 & $\mathrm{~N}$ & -0.689 & -8.013 & -1.013 & $\mathrm{H}$ & 4.818 & -5.167 & 4.430 \\
\hline $\mathrm{H}$ & -3.153 & 0.753 & 2.168 & $\mathrm{C}$ & -0.403 & -9.184 & -0.200 & $\mathrm{H}$ & 6.164 & -4.793 & 3.305 \\
\hline $\mathrm{H}$ & -2.569 & 0.265 & 0.544 & $\mathrm{H}$ & -0.775 & -10.092 & -0.697 & $\mathrm{~N}$ & 4.532 & -3.487 & 3.279 \\
\hline $\mathrm{N}$ & -3.163 & -1.302 & 1.742 & $\mathrm{H}$ & -5.677 & -6.632 & 0.785 & $\mathrm{C}$ & 4.995 & -2.512 & 2.296 \\
\hline C & -3.912 & -1.756 & 2.895 & $\mathrm{~N}$ & -4.203 & -6.322 & 2.251 & $\mathrm{H}$ & 6.080 & -2.371 & 2.390 \\
\hline $\mathrm{H}$ & -4.568 & -0.963 & 3.278 & $\mathrm{~N}$ & -0.858 & -9.149 & 1.171 & $\mathrm{~N}$ & 4.642 & -2.762 & 0.917 \\
\hline $\mathrm{N}$ & -3.116 & -2.321 & 3.977 & $\mathrm{C}$ & 0.182 & -8.945 & 2.076 & $\mathrm{C}$ & 3.622 & -1.939 & 0.467 \\
\hline $\mathrm{C}$ & -3.353 & -3.705 & 4.175 & $\mathrm{O}$ & 0.086 & -8.926 & 3.287 & $\mathrm{O}$ & 3.145 & -1.899 & -0.645 \\
\hline $\mathrm{O}$ & -2.833 & -4.363 & 5.049 & $\mathrm{~N}$ & 1.356 & -8.816 & 1.336 & $\mathrm{~N}$ & 3.260 & -1.103 & 1.537 \\
\hline $\mathrm{N}$ & -4.278 & -4.090 & 3.238 & $\mathrm{C}$ & 1.157 & -9.145 & -0.067 & $\mathrm{C}$ & 4.171 & -1.225 & 2.659 \\
\hline $\mathrm{C}$ & -4.701 & -3.010 & 2.362 & $\mathrm{H}$ & 1.637 & -10.106 & -0.303 & $\mathrm{H}$ & 4.794 & -0.325 & 2.758 \\
\hline $\mathrm{H}$ & -5.791 & -2.889 & 2.429 & $\mathrm{~N}$ & 1.551 & -8.144 & -1.030 & $\mathrm{~N}$ & 3.578 & -1.566 & 3.936 \\
\hline $\mathrm{N}$ & -4.291 & -3.096 & 0.975 & $\mathrm{C}$ & 0.464 & -7.481 & -1.592 & $\mathrm{C}$ & 3.775 & -2.916 & 4.280 \\
\hline $\mathrm{C}$ & -3.499 & -2.032 & 0.579 & $\mathrm{O}$ & 0.507 & -6.631 & -2.457 & $\mathrm{O}$ & 3.366 & -3.434 & 5.299 \\
\hline $\mathrm{O}$ & -3.168 & -1.735 & -0.546 & $\mathrm{C}$ & 2.914 & -7.829 & -1.404 & $\mathrm{C}$ & 2.392 & 0.018 & 1.308 \\
\hline $\mathrm{C}$ & -4.820 & -5.450 & 3.212 & $\mathrm{H}$ & 2.875 & -7.329 & -2.375 & $\mathrm{H}$ & 2.858 & 0.943 & 1.678 \\
\hline $\mathrm{H}$ & -5.899 & -5.379 & 3.026 & $\mathrm{H}$ & 3.478 & -8.767 & -1.491 & $\mathrm{H}$ & 2.222 & 0.095 & 0.230 \\
\hline $\mathrm{H}$ & -4.641 & -5.883 & 4.200 & $\mathrm{C}$ & 2.645 & -8.852 & 1.997 & $\mathrm{C}$ & 2.753 & -0.729 & 4.743 \\
\hline $\mathrm{C}$ & -4.840 & -4.033 & -0.005 & $\mathrm{H}$ & 3.232 & -9.700 & 1.614 & $\mathrm{H}$ & 2.768 & -1.121 & 5.762 \\
\hline $\mathrm{H}$ & -4.663 & -3.587 & -0.987 & $\mathrm{H}$ & 2.451 & -8.988 & 3.064 & $\mathrm{H}$ & 3.119 & 0.302 & 4.730 \\
\hline $\mathrm{H}$ & -5.918 & -4.133 & 0.170 & $\mathrm{~N}$ & 3.430 & -7.643 & 1.853 & $\mathrm{H}$ & -0.803 & -2.067 & 3.326 \\
\hline $\mathrm{N}$ & -4.231 & -5.337 & -0.005 & & & & & & & & \\
\hline
\end{tabular}




\begin{tabular}{|c|c|c|c|c|c|c|c|c|c|c|c|}
\hline \multicolumn{12}{|c|}{ CB[6]-H ${ }^{+} \_N 4$} \\
\hline $\mathrm{O}$ & 0.144 & -0.512 & 0.096 & $\mathrm{C}$ & -4.482 & -6.477 & 0.978 & $\mathrm{H}$ & 4.971 & -8.109 & 0.270 \\
\hline $\mathrm{C}$ & 0.084 & -0.279 & 1.276 & $\mathrm{H}$ & -5.566 & -6.658 & 1.031 & $\mathrm{~N}$ & 3.481 & -6.872 & -0.543 \\
\hline $\mathrm{N}$ & 1.204 & -0.076 & 2.130 & $\mathrm{~N}$ & -3.939 & -6.300 & 2.314 & $\mathrm{C}$ & 3.780 & -5.556 & -0.875 \\
\hline C & 0.792 & 0.495 & 3.361 & $\mathrm{C}$ & -3.122 & -7.366 & 2.702 & $\mathrm{O}$ & 3.434 & -4.956 & -1.871 \\
\hline $\mathrm{H}$ & 1.075 & 1.550 & 3.468 & $\mathrm{O}$ & -2.695 & -7.563 & 3.821 & $\mathrm{~N}$ & 4.611 & -5.054 & 0.131 \\
\hline $\mathrm{N}$ & 1.269 & -0.198 & 4.646 & $\mathrm{~N}$ & -2.939 & -8.171 & 1.587 & $\mathrm{C}$ & 4.935 & -6.041 & 1.134 \\
\hline $\mathrm{C}$ & 0.113 & -1.134 & 5.124 & $\mathrm{C}$ & -3.677 & -7.709 & 0.431 & $\mathrm{H}$ & 6.026 & -6.136 & 1.240 \\
\hline $\mathrm{O}$ & 0.283 & -1.860 & 6.058 & $\mathrm{H}$ & -4.324 & -8.515 & 0.054 & $\mathrm{~N}$ & 4.319 & -5.861 & 2.439 \\
\hline $\mathrm{N}$ & -0.958 & -0.808 & 4.382 & $\mathrm{~N}$ & -2.904 & -7.140 & -0.658 & $\mathrm{C}$ & 3.560 & -6.975 & 2.824 \\
\hline $\mathrm{C}$ & -0.760 & 0.261 & 3.389 & $\mathrm{C}$ & -3.284 & -5.837 & -0.959 & $\mathrm{O}$ & 3.089 & -7.160 & 3.927 \\
\hline $\mathrm{H}$ & -1.325 & 1.146 & 3.709 & $\mathrm{O}$ & -2.931 & -5.178 & -1.916 & $\mathrm{C}$ & 5.117 & -3.708 & 0.085 \\
\hline $\mathrm{N}$ & -1.063 & -0.085 & 2.037 & $\mathrm{C}$ & -2.131 & -9.377 & 1.640 & $\mathrm{H}$ & 6.191 & -3.712 & 0.315 \\
\hline C & -2.311 & -1.295 & 4.776 & $\mathrm{H}$ & -2.648 & -10.170 & 1.086 & $\mathrm{H}$ & 4.956 & -3.340 & -0.932 \\
\hline $\mathrm{H}$ & -2.172 & -1.848 & 5.709 & $\mathrm{H}$ & -2.045 & -9.655 & 2.693 & $\mathrm{C}$ & 4.796 & -4.940 & 3.434 \\
\hline $\mathrm{H}$ & -2.926 & -0.402 & 4.950 & $\mathrm{C}$ & -2.092 & -7.913 & -1.578 & $\mathrm{H}$ & 4.473 & -5.316 & 4.409 \\
\hline C & -2.400 & -0.060 & 1.430 & $\mathrm{H}$ & -1.991 & -7.317 & -2.489 & $\mathrm{H}$ & 5.893 & -4.881 & 3.401 \\
\hline $\mathrm{H}$ & -2.947 & 0.782 & 1.874 & $\mathrm{H}$ & -2.604 & -8.859 & -1.806 & $\mathrm{~N}$ & 4.270 & -3.582 & 3.305 \\
\hline $\mathrm{H}$ & -2.260 & 0.111 & 0.359 & $\mathrm{~N}$ & -0.756 & -8.196 & -1.103 & $\mathrm{C}$ & 4.801 & -2.598 & 2.376 \\
\hline $\mathrm{N}$ & -3.150 & -1.274 & 1.560 & $\mathrm{C}$ & -0.399 & -9.321 & -0.262 & $\mathrm{H}$ & 5.893 & -2.540 & 2.489 \\
\hline C & -3.807 & -1.716 & 2.764 & $\mathrm{~N}$ & -0.782 & -9.242 & 1.133 & $\mathrm{~N}$ & 4.452 & -2.764 & 0.982 \\
\hline $\mathrm{H}$ & -4.499 & -0.946 & 3.137 & $\mathrm{C}$ & 0.311 & -9.151 & 1.990 & $\mathrm{C}$ & 3.698 & -1.708 & 0.490 \\
\hline $\mathrm{N}$ & -2.934 & -2.161 & 3.835 & $\mathrm{O}$ & 0.282 & -9.200 & 3.203 & $\mathrm{O}$ & 3.351 & -1.516 & -0.652 \\
\hline $\mathrm{C}$ & -3.121 & -3.523 & 4.149 & $\mathrm{~N}$ & 1.452 & -9.045 & 1.196 & $\mathrm{~N}$ & 3.454 & -0.840 & 1.572 \\
\hline $\mathrm{O}$ & -2.617 & -4.087 & 5.097 & $\mathrm{C}$ & 1.170 & -9.251 & -0.214 & $\mathrm{C}$ & 4.072 & -1.275 & 2.788 \\
\hline $\mathrm{N}$ & -4.002 & -4.037 & 3.222 & $\mathrm{H}$ & 1.654 & -10.175 & -0.562 & $\mathrm{H}$ & 4.757 & -0.511 & 3.183 \\
\hline $\mathrm{C}$ & -4.533 & -3.034 & 2.317 & $\mathrm{~N}$ & 1.484 & -8.159 & -1.107 & $\mathrm{~N}$ & 3.157 & -1.697 & 3.851 \\
\hline $\mathrm{H}$ & -5.626 & -2.982 & 2.424 & $\mathrm{C}$ & 0.352 & -7.561 & -1.654 & $\mathrm{C}$ & 3.383 & -3.064 & 4.213 \\
\hline $\mathrm{N}$ & -4.180 & -3.160 & 0.917 & $\mathrm{O}$ & 0.338 & -6.682 & -2.492 & $\mathrm{O}$ & 2.896 & -3.592 & 5.186 \\
\hline $\mathrm{C}$ & -3.431 & -2.089 & 0.452 & $\mathrm{C}$ & 2.813 & -7.748 & -1.493 & $\mathrm{C}$ & 2.502 & 0.223 & 1.490 \\
\hline $\mathrm{O}$ & -3.111 & -1.853 & -0.692 & $\mathrm{H}$ & 2.719 & -7.187 & -2.426 & $\mathrm{H}$ & 2.905 & 1.137 & 1.948 \\
\hline $\mathrm{C}$ & -4.490 & -5.408 & 3.304 & $\mathrm{H}$ & 3.432 & -8.641 & -1.655 & $\mathrm{H}$ & 2.311 & 0.393 & 0.427 \\
\hline $\mathrm{H}$ & -5.586 & -5.388 & 3.222 & $\mathrm{C}$ & 2.772 & -9.085 & 1.784 & C & 2.706 & -0.815 & 4.840 \\
\hline $\mathrm{H}$ & -4.197 & -5.793 & 4.284 & $\mathrm{H}$ & 3.375 & -9.856 & 1.286 & $\mathrm{H}$ & 2.597 & -1.346 & 5.791 \\
\hline $\mathrm{C}$ & -4.785 & -4.122 & 0.002 & $\mathrm{H}$ & 2.643 & -9.339 & 2.839 & $\mathrm{H}$ & 3.350 & 0.066 & 4.938 \\
\hline $\mathrm{H}$ & -4.651 & -3.721 & -1.006 & $\mathrm{~N}$ & 3.503 & -7.830 & 1.736 & $\mathrm{H}$ & 1.259 & 0.532 & 5.368 \\
\hline $\mathrm{H}$ & -5.855 & -4.201 & 0.233 & $\mathrm{C}$ & 4.250 & -7.345 & 0.595 & $\mathrm{H}$ & -0.776 & -10.256 & -0.702 \\
\hline $\mathrm{N}$ & -4.196 & -5.436 & 0.018 & & & & & & & & \\
\hline
\end{tabular}




\begin{tabular}{|c|c|c|c|c|c|c|c|c|c|c|c|}
\hline \multicolumn{12}{|c|}{ CB[6]A } \\
\hline C & -0.019 & 0.443 & 0.005 & $\mathrm{~N}$ & -0.737 & 6.898 & -4.108 & $\mathrm{~N}$ & -1.497 & 3.573 & 4.886 \\
\hline $\mathrm{N}$ & -0.013 & 0.281 & 1.447 & C & -0.578 & 5.487 & -3.757 & C & -2.354 & 2.491 & 4.408 \\
\hline C & 1.342 & 0.047 & 1.940 & C & 0.359 & 9.182 & -1.824 & $\mathrm{H}$ & -3.056 & 2.226 & 5.212 \\
\hline $\mathrm{H}$ & 1.402 & -0.935 & 2.432 & $\mathrm{H}$ & 0.183 & 9.868 & -2.665 & $\mathrm{~N}$ & -3.077 & 2.693 & 3.154 \\
\hline $\mathrm{N}$ & 1.926 & 1.044 & 2.835 & $\mathrm{H}$ & 1.191 & 9.593 & -1.235 & C & -2.651 & 1.736 & 2.151 \\
\hline C & 2.376 & 2.149 & 1.987 & C & -1.982 & 7.531 & -3.685 & $\mathrm{~N}$ & -1.972 & 0.695 & 2.923 \\
\hline $\mathrm{N}$ & 2.776 & 1.499 & 0.753 & $\mathrm{H}$ & -2.799 & 6.970 & -4.160 & C & -1.352 & 1.363 & 4.065 \\
\hline C & 2.212 & 0.155 & 0.664 & $\mathrm{H}$ & -1.984 & 8.542 & -4.117 & $\mathrm{H}$ & -1.228 & 0.626 & 4.872 \\
\hline $\mathrm{H}$ & 3.017 & -0.592 & 0.616 & $\mathrm{~N}$ & -2.237 & 7.628 & -2.262 & $\mathrm{~N}$ & -0.099 & 2.082 & 3.841 \\
\hline $\mathrm{N}$ & 1.265 & -0.119 & -0.415 & C & -2.114 & 8.912 & -1.577 & C & -0.257 & 3.498 & 4.113 \\
\hline C & 4.028 & 1.816 & 0.099 & $\mathrm{H}$ & -2.402 & 9.731 & -2.253 & C & -1.158 & -0.245 & 2.159 \\
\hline $\mathrm{H}$ & 4.677 & 2.353 & 0.804 & $\mathrm{~N}$ & -0.826 & 9.247 & -0.975 & $\mathrm{H}$ & -0.815 & -1.014 & 2.867 \\
\hline $\mathrm{H}$ & 4.538 & 0.878 & -0.166 & C & -0.754 & 8.519 & 0.292 & $\mathrm{H}$ & -1.832 & -0.736 & 1.444 \\
\hline C & 1.686 & 0.179 & -1.779 & $\mathrm{~N}$ & -2.133 & 8.463 & 0.741 & C & 1.171 & 1.412 & 4.028 \\
\hline $\mathrm{H}$ & 2.600 & -0.404 & -1.961 & C & -3.052 & 8.759 & -0.357 & $\mathrm{H}$ & 1.829 & 2.051 & 4.633 \\
\hline $\mathrm{H}$ & 0.906 & -0.219 & -2.444 & $\mathrm{H}$ & -3.632 & 9.666 & -0.131 & $\mathrm{H}$ & 1.005 & 0.484 & 4.593 \\
\hline $\mathrm{N}$ & 1.936 & 1.565 & -2.119 & $\mathrm{~N}$ & -3.983 & 7.714 & -0.775 & $\mathrm{H}$ & 3.224 & 2.673 & 2.455 \\
\hline C & 3.306 & 2.047 & -2.283 & C & -3.221 & 6.784 & -1.610 & $\mathrm{H}$ & 1.570 & 2.888 & 1.818 \\
\hline $\mathrm{H}$ & 3.944 & 1.248 & -2.689 & C & -4.836 & 7.114 & 0.245 & $\mathrm{H}$ & 0.587 & 3.887 & 4.704 \\
\hline $\mathrm{N}$ & 3.974 & 2.620 & -1.118 & $\mathrm{H}$ & -5.546 & 6.461 & -0.283 & $\mathrm{H}$ & -0.320 & 4.091 & 3.181 \\
\hline C & 3.461 & 3.982 & -0.971 & $\mathrm{H}$ & -5.415 & 7.934 & 0.694 & $\mathrm{H}$ & -1.091 & 7.084 & 3.957 \\
\hline $\mathrm{N}$ & 3.196 & 4.405 & -2.334 & C & -2.498 & 8.776 & 2.107 & $\mathrm{H}$ & -1.297 & 6.385 & 2.328 \\
\hline C & 3.147 & 3.256 & -3.236 & $\mathrm{H}$ & -3.349 & 9.473 & 2.097 & $\mathrm{H}$ & -0.324 & 7.508 & 0.159 \\
\hline $\mathrm{H}$ & 3.945 & 3.330 & -3.989 & $\mathrm{H}$ & -1.659 & 9.291 & 2.594 & $\mathrm{H}$ & -0.123 & 9.063 & 1.012 \\
\hline $\mathrm{N}$ & 1.889 & 2.979 & -3.925 & $\mathrm{~N}$ & -2.874 & 7.668 & 2.979 & $\mathrm{H}$ & 1.576 & 6.308 & -1.193 \\
\hline C & 1.019 & 2.320 & -2.952 & C & -4.082 & 6.918 & 2.646 & $\mathrm{H}$ & 2.527 & 7.819 & -1.213 \\
\hline C & 3.623 & 5.700 & -2.822 & $\mathrm{H}$ & -4.954 & 7.552 & 2.867 & $\mathrm{H}$ & 2.547 & 4.009 & -0.348 \\
\hline $\mathrm{H}$ & 4.129 & 5.567 & -3.789 & $\mathrm{~N}$ & -4.193 & 6.360 & 1.300 & $\mathrm{H}$ & 4.215 & 4.628 & -0.493 \\
\hline $\mathrm{H}$ & 4.359 & 6.122 & -2.123 & C & -4.253 & 4.911 & 1.344 & $\mathrm{H}$ & -2.745 & 5.990 & -1.004 \\
\hline C & 1.287 & 4.059 & -4.700 & $\mathrm{~N}$ & -4.598 & 4.616 & 2.735 & $\mathrm{H}$ & -3.881 & 6.299 & -2.346 \\
\hline $\mathrm{H}$ & 0.439 & 3.621 & -5.246 & C & -3.985 & 5.664 & 3.547 & $\mathrm{H}$ & -5.029 & 4.523 & 0.666 \\
\hline $\mathrm{H}$ & 2.034 & 4.366 & -5.446 & $\mathrm{H}$ & -4.553 & 5.750 & 4.485 & $\mathrm{H}$ & -3.289 & 4.451 & 1.057 \\
\hline $\mathrm{N}$ & 0.832 & 5.230 & -3.981 & $\mathrm{~N}$ & -2.555 & 5.562 & 3.831 & $\mathrm{H}$ & -3.513 & 1.314 & 1.611 \\
\hline C & 1.587 & 6.480 & -4.045 & C & -1.832 & 6.678 & 3.251 & $\mathrm{H}$ & -1.975 & 2.196 & 1.406 \\
\hline $\mathrm{H}$ & 2.061 & 6.586 & -5.031 & C & -4.421 & 3.233 & 3.164 & $\mathrm{H}$ & -0.851 & -0.112 & -0.455 \\
\hline $\mathrm{N}$ & 2.600 & 6.721 & -3.020 & $\mathrm{H}$ & -4.825 & 3.166 & 4.185 & $\mathrm{H}$ & -0.114 & 1.506 & -0.288 \\
\hline C & 1.886 & 7.163 & -1.823 & $\mathrm{H}$ & -5.061 & 2.617 & 2.518 & $\mathrm{H}$ & 0.439 & 3.054 & -2.362 \\
\hline $\mathrm{N}$ & 0.743 & 7.887 & -2.347 & C & -2.091 & 4.897 & 5.031 & $\mathrm{H}$ & 0.304 & 1.655 & -3.462 \\
\hline C & 0.516 & 7.559 & -3.752 & $\mathrm{H}$ & -1.338 & 5.528 & 5.523 & $\mathrm{H}$ & -0.869 & 5.294 & -2.707 \\
\hline $\mathrm{H}$ & 0.620 & 8.461 & -4.373 & $\mathrm{H}$ & -2.935 & 4.790 & 5.727 & $\mathrm{H}$ & -1.206 & 4.856 & -4.405 \\
\hline
\end{tabular}




\begin{tabular}{|c|c|c|c|c|c|c|c|c|c|c|c|}
\hline \multicolumn{12}{|c|}{ CB[6]A-H ${ }^{+} \_N 2$} \\
\hline $\mathrm{C}$ & -0.043 & -0.269 & -0.031 & $\mathrm{C}$ & -1.123 & 4.469 & -4.295 & $\mathrm{C}$ & -2.685 & 2.171 & 4.166 \\
\hline $\mathrm{N}$ & -0.048 & -0.033 & 1.404 & $\mathrm{C}$ & -0.692 & 8.450 & -2.824 & $\mathrm{H}$ & -3.361 & 1.905 & 4.991 \\
\hline $\mathrm{C}$ & 1.310 & -0.002 & 1.940 & $\mathrm{H}$ & -0.964 & 9.003 & -3.734 & $\mathrm{~N}$ & -3.404 & 2.144 & 2.895 \\
\hline $\mathrm{H}$ & 1.530 & -0.892 & 2.547 & $\mathrm{H}$ & 0.072 & 9.040 & -2.300 & $\mathrm{C}$ & -2.855 & 1.152 & 1.999 \\
\hline $\mathrm{N}$ & 1.736 & 1.169 & 2.707 & $\mathrm{C}$ & -2.786 & 6.296 & -4.463 & $\mathrm{~N}$ & -2.035 & 0.307 & 2.869 \\
\hline $\mathrm{C}$ & 1.868 & 2.272 & 1.779 & $\mathrm{H}$ & -3.514 & 5.580 & -4.868 & $\mathrm{C}$ & -1.544 & 1.146 & 3.954 \\
\hline $\mathrm{N}$ & 2.387 & 1.642 & 0.521 & $\mathrm{H}$ & -2.916 & 7.240 & -5.010 & $\mathrm{H}$ & -1.350 & 0.514 & 4.831 \\
\hline $\mathrm{C}$ & 2.162 & 0.069 & 0.673 & $\mathrm{~N}$ & -3.056 & 6.513 & -3.058 & $\mathrm{~N}$ & -0.379 & 1.994 & 3.677 \\
\hline $\mathrm{H}$ & 3.158 & -0.370 & 0.754 & $\mathrm{C}$ & -3.103 & 7.876 & -2.524 & $\mathrm{C}$ & -0.723 & 3.405 & 3.799 \\
\hline $\mathrm{N}$ & 1.380 & -0.469 & -0.370 & $\mathrm{H}$ & -3.489 & 8.569 & -3.284 & $\mathrm{C}$ & -1.125 & -0.610 & 2.231 \\
\hline $\mathrm{C}$ & 3.792 & 2.062 & -0.023 & $\mathrm{~N}$ & -1.872 & 8.431 & -1.974 & $\mathrm{H}$ & -0.671 & -1.229 & 3.018 \\
\hline $\mathrm{H}$ & 4.211 & 2.769 & 0.695 & C & -1.713 & 7.868 & -0.634 & $\mathrm{H}$ & -1.719 & -1.276 & 1.593 \\
\hline $\mathrm{H}$ & 4.401 & 1.155 & -0.032 & $\mathrm{~N}$ & -3.074 & 7.665 & -0.171 & $\mathrm{C}$ & 0.952 & 1.518 & 3.915 \\
\hline $\mathrm{C}$ & 1.794 & -0.207 & -1.751 & C & -4.020 & 7.743 & -1.288 & $\mathrm{H}$ & 1.539 & 2.276 & 4.451 \\
\hline $\mathrm{H}$ & 2.788 & -0.650 & -1.885 & $\mathrm{H}$ & -4.699 & 8.596 & -1.153 & $\mathrm{H}$ & 0.933 & 0.615 & 4.539 \\
\hline $\mathrm{H}$ & 1.102 & -0.741 & -2.409 & $\mathrm{~N}$ & -4.817 & 6.559 & -1.587 & $\mathrm{H}$ & 2.570 & 3.023 & 2.153 \\
\hline $\mathrm{N}$ & 1.839 & 1.219 & -2.100 & $\mathrm{C}$ & -3.946 & 5.639 & -2.314 & $\mathrm{H}$ & 0.911 & 2.753 & 1.532 \\
\hline C & 3.163 & 1.821 & -2.401 & $\mathrm{C}$ & -5.616 & 5.983 & -0.512 & $\mathrm{H}$ & 0.049 & 3.956 & 4.358 \\
\hline $\mathrm{H}$ & 3.883 & 1.046 & -2.685 & $\mathrm{H}$ & -6.242 & 5.202 & -0.964 & $\mathrm{H}$ & -0.835 & 3.881 & 2.806 \\
\hline $\mathrm{N}$ & 3.720 & 2.634 & -1.316 & $\mathrm{H}$ & -6.288 & 6.777 & -0.158 & $\mathrm{H}$ & -1.949 & 6.798 & 3.209 \\
\hline $\mathrm{C}$ & 3.146 & 3.989 & -1.426 & C & -3.491 & 8.091 & 1.153 & $\mathrm{H}$ & -2.029 & 5.893 & 1.670 \\
\hline $\mathrm{N}$ & 2.832 & 4.120 & -2.821 & $\mathrm{H}$ & -4.412 & 8.683 & 1.065 & $\mathrm{H}$ & -1.144 & 6.917 & -0.657 \\
\hline C & 2.875 & 2.841 & -3.525 & $\mathrm{H}$ & -2.720 & 8.747 & 1.580 & $\mathrm{H}$ & -1.169 & 8.571 & 0.015 \\
\hline $\mathrm{H}$ & 3.652 & 2.864 & -4.302 & $\mathrm{~N}$ & -3.755 & 7.052 & 2.142 & $\mathrm{H}$ & 0.988 & 5.936 & -1.878 \\
\hline $\mathrm{N}$ & 1.650 & 2.321 & -4.127 & $\mathrm{C}$ & -4.872 & 6.143 & 1.897 & $\mathrm{H}$ & 1.696 & 7.546 & -2.181 \\
\hline $\mathrm{C}$ & 0.849 & 1.763 & -3.048 & $\mathrm{H}$ & -5.809 & 6.699 & 2.042 & $\mathrm{H}$ & 2.252 & 4.101 & -0.774 \\
\hline C & 3.041 & 5.385 & -3.527 & $\mathrm{~N}$ & -4.905 & 5.425 & 0.623 & $\mathrm{H}$ & 3.882 & 4.738 & -1.097 \\
\hline $\mathrm{H}$ & 3.526 & 5.166 & -4.488 & C & -4.811 & 3.995 & 0.829 & $\mathrm{H}$ & -3.385 & 4.979 & -1.623 \\
\hline $\mathrm{H}$ & 3.739 & 5.996 & -2.940 & $\mathrm{~N}$ & -5.124 & 3.821 & 2.248 & $\mathrm{H}$ & -4.536 & 5.001 & -2.989 \\
\hline $\mathrm{C}$ & 0.921 & 3.196 & -5.057 & C & -4.655 & 5.019 & 2.936 & $\mathrm{H}$ & -5.539 & 3.451 & 0.207 \\
\hline $\mathrm{H}$ & 0.150 & 2.573 & -5.529 & $\mathrm{H}$ & -5.248 & 5.148 & 3.853 & $\mathrm{H}$ & -3.802 & 3.609 & 0.585 \\
\hline $\mathrm{H}$ & 1.634 & 3.482 & -5.841 & $\mathrm{~N}$ & -3.226 & 5.109 & 3.244 & $\mathrm{H}$ & -3.648 & 0.555 & 1.523 \\
\hline $\mathrm{N}$ & 0.319 & 4.375 & -4.486 & $\mathrm{C}$ & -2.619 & 6.230 & 2.545 & $\mathrm{H}$ & -2.246 & 1.609 & 1.193 \\
\hline C & 0.892 & 5.697 & -4.752 & $\mathrm{C}$ & -4.807 & 2.530 & 2.833 & $\mathrm{H}$ & -0.618 & -1.166 & -0.307 \\
\hline $\mathrm{H}$ & 1.325 & 5.731 & -5.761 & $\mathrm{H}$ & -5.215 & 2.530 & 3.853 & $\mathrm{H}$ & -0.470 & 0.585 & -0.588 \\
\hline $\mathrm{N}$ & 1.878 & 6.200 & -3.803 & $\mathrm{H}$ & -5.358 & 1.772 & 2.261 & $\mathrm{H}$ & 0.226 & 2.526 & -2.553 \\
\hline C & 1.141 & 6.718 & -2.649 & C & -2.732 & 4.652 & 4.522 & $\mathrm{H}$ & 0.190 & 0.970 & -3.425 \\
\hline $\mathrm{N}$ & -0.116 & 7.170 & -3.207 & $\mathrm{H}$ & -2.074 & 5.416 & 4.959 & $\mathrm{H}$ & -1.397 & 4.367 & -3.228 \\
\hline C & -0.309 & 6.650 & -4.563 & $\mathrm{H}$ & -3.577 & 4.517 & 5.211 & $\mathrm{H}$ & -1.652 & 3.686 & -4.859 \\
\hline $\mathrm{H}$ & -0.331 & 7.476 & -5.287 & $\mathrm{~N}$ & -1.978 & 3.396 & 4.537 & $\mathrm{H}$ & 1.772 & 1.866 & -0.281 \\
\hline $\mathrm{N}$ & -1.460 & 5.789 & -4.814 & & & & & & & & \\
\hline
\end{tabular}




\begin{tabular}{|c|c|c|c|c|c|c|c|c|c|c|c|}
\hline \multicolumn{12}{|c|}{$\mathrm{CB}[6] \mathrm{A}-\mathrm{H}^{+} \_\mathrm{N} 4$} \\
\hline $\mathrm{C}$ & 0.006 & 0.018 & 0.083 & $\mathrm{C}$ & -1.148 & 4.518 & -4.315 & $\mathrm{C}$ & -2.635 & 2.217 & 4.113 \\
\hline $\mathrm{N}$ & 0.074 & -0.098 & 1.538 & $\mathrm{C}$ & -0.717 & 8.481 & -2.767 & $\mathrm{H}$ & -3.304 & 1.980 & 4.952 \\
\hline $\mathrm{C}$ & 1.403 & -0.129 & 1.978 & $\mathrm{H}$ & -0.947 & 9.040 & -3.684 & $\mathrm{~N}$ & -3.353 & 2.138 & 2.844 \\
\hline $\mathrm{H}$ & 1.641 & -0.959 & 2.654 & $\mathrm{H}$ & 0.039 & 9.055 & -2.214 & $\mathrm{C}$ & -2.814 & 1.098 & 1.994 \\
\hline $\mathrm{N}$ & 1.854 & 1.167 & 2.775 & $\mathrm{C}$ & -2.778 & 6.373 & -4.491 & $\mathrm{~N}$ & -1.968 & 0.308 & 2.899 \\
\hline $\mathrm{C}$ & 2.129 & 2.151 & 1.663 & $\mathrm{H}$ & -3.504 & 5.670 & -4.922 & $\mathrm{C}$ & -1.493 & 1.191 & 3.935 \\
\hline $\mathrm{N}$ & 2.815 & 1.330 & 0.722 & $\mathrm{H}$ & -2.887 & 7.326 & -5.027 & $\mathrm{H}$ & -1.271 & 0.614 & 4.842 \\
\hline $\mathrm{C}$ & 2.277 & -0.034 & 0.682 & $\mathrm{~N}$ & -3.086 & 6.581 & -3.092 & $\mathrm{~N}$ & -0.326 & 2.049 & 3.607 \\
\hline $\mathrm{H}$ & 3.121 & -0.734 & 0.665 & $\mathrm{C}$ & -3.146 & 7.931 & -2.539 & $\mathrm{C}$ & -0.723 & 3.461 & 3.620 \\
\hline $\mathrm{N}$ & 1.324 & -0.435 & -0.339 & $\mathrm{H}$ & -3.515 & 8.635 & -3.298 & $\mathrm{C}$ & -1.045 & -0.638 & 2.321 \\
\hline $\mathrm{C}$ & 3.945 & 1.806 & -0.090 & $\mathrm{~N}$ & -1.926 & 8.486 & -1.954 & $\mathrm{H}$ & -0.626 & -1.242 & 3.136 \\
\hline $\mathrm{H}$ & 4.533 & 2.488 & 0.538 & $\mathrm{C}$ & -1.805 & 7.927 & -0.610 & $\mathrm{H}$ & -1.618 & -1.310 & 1.672 \\
\hline $\mathrm{H}$ & 4.568 & 0.929 & -0.301 & $\mathrm{~N}$ & -3.178 & 7.739 & -0.184 & $\mathrm{C}$ & 0.959 & 1.646 & 3.961 \\
\hline C & 1.677 & -0.222 & -1.745 & C & -4.093 & 7.780 & -1.323 & $\mathrm{H}$ & 1.548 & 2.455 & 4.411 \\
\hline $\mathrm{H}$ & 2.637 & -0.731 & -1.906 & $\mathrm{H}$ & -4.801 & 8.613 & -1.212 & $\mathrm{H}$ & 0.954 & 0.785 & 4.642 \\
\hline $\mathrm{H}$ & 0.924 & -0.754 & -2.339 & $\mathrm{~N}$ & -4.851 & 6.569 & -1.630 & $\mathrm{H}$ & 2.755 & 2.974 & 2.025 \\
\hline $\mathrm{N}$ & 1.765 & 1.153 & -2.175 & $\mathrm{C}$ & -3.950 & 5.678 & -2.359 & $\mathrm{H}$ & 1.151 & 2.543 & 1.357 \\
\hline C & 3.087 & 1.735 & -2.432 & $\mathrm{C}$ & -5.637 & 5.965 & -0.564 & $\mathrm{H}$ & 0.056 & 4.087 & 4.077 \\
\hline $\mathrm{H}$ & 3.791 & 0.963 & -2.773 & $\mathrm{H}$ & -6.237 & 5.168 & -1.024 & $\mathrm{H}$ & -0.911 & 3.825 & 2.595 \\
\hline $\mathrm{N}$ & 3.694 & 2.478 & -1.339 & $\mathrm{H}$ & -6.335 & 6.735 & -0.207 & $\mathrm{H}$ & -2.019 & 6.884 & 3.150 \\
\hline C & 3.059 & 3.799 & -1.312 & $\mathrm{C}$ & -3.626 & 8.142 & 1.130 & $\mathrm{H}$ & -2.086 & 5.999 & 1.599 \\
\hline $\mathrm{N}$ & 2.712 & 4.048 & -2.695 & $\mathrm{H}$ & -4.574 & 8.689 & 1.037 & $\mathrm{H}$ & -1.242 & 6.972 & -0.614 \\
\hline C & 2.804 & 2.819 & -3.491 & $\mathrm{H}$ & -2.893 & 8.831 & 1.571 & $\mathrm{H}$ & -1.274 & 8.629 & 0.052 \\
\hline $\mathrm{H}$ & 3.598 & 2.913 & -4.245 & $\mathrm{~N}$ & -3.849 & 7.083 & 2.114 & $\mathrm{H}$ & 0.824 & 5.876 & -1.783 \\
\hline $\mathrm{N}$ & 1.600 & 2.328 & -4.148 & $\mathrm{C}$ & -4.924 & 6.127 & 1.855 & $\mathrm{H}$ & 1.591 & 7.477 & -1.980 \\
\hline C & 0.785 & 1.704 & -3.111 & $\mathrm{H}$ & -5.884 & 6.640 & 2.003 & $\mathrm{H}$ & 2.161 & 3.810 & -0.659 \\
\hline C & 2.977 & 5.340 & -3.319 & $\mathrm{~N}$ & -4.919 & 5.418 & 0.576 & $\mathrm{H}$ & 3.762 & 4.554 & -0.927 \\
\hline $\mathrm{H}$ & 3.521 & 5.171 & -4.259 & C & -4.790 & 3.988 & 0.773 & $\mathrm{H}$ & -3.377 & 5.027 & -1.670 \\
\hline $\mathrm{H}$ & 3.637 & 5.920 & -2.661 & $\mathrm{~N}$ & -5.092 & 3.799 & 2.193 & $\mathrm{H}$ & -4.520 & 5.028 & -3.042 \\
\hline $\mathrm{C}$ & 0.898 & 3.236 & -5.056 & $\mathrm{C}$ & -4.660 & 5.006 & 2.885 & $\mathrm{H}$ & -5.508 & 3.430 & 0.152 \\
\hline $\mathrm{H}$ & 0.128 & 2.640 & -5.565 & $\mathrm{H}$ & -5.244 & 5.111 & 3.810 & $\mathrm{H}$ & -3.773 & 3.627 & 0.524 \\
\hline $\mathrm{H}$ & 1.628 & 3.544 & -5.817 & $\mathrm{~N}$ & -3.228 & 5.143 & 3.173 & $\mathrm{H}$ & -3.610 & 0.467 & 1.570 \\
\hline $\mathrm{N}$ & 0.293 & 4.406 & -4.466 & $\mathrm{C}$ & -2.676 & 6.301 & 2.485 & $\mathrm{H}$ & -2.228 & 1.515 & 1.153 \\
\hline C & 0.900 & 5.724 & -4.652 & $\mathrm{C}$ & -4.765 & 2.515 & 2.778 & $\mathrm{H}$ & -0.777 & -0.639 & -0.315 \\
\hline $\mathrm{H}$ & 1.391 & 5.781 & -5.633 & $\mathrm{H}$ & -5.175 & 2.510 & 3.797 & $\mathrm{H}$ & -0.212 & 1.051 & -0.238 \\
\hline $\mathrm{N}$ & 1.840 & 6.184 & -3.635 & $\mathrm{H}$ & -5.302 & 1.749 & 2.204 & $\mathrm{H}$ & 0.128 & 2.436 & -2.610 \\
\hline C & 1.046 & 6.681 & -2.512 & $\mathrm{C}$ & -2.702 & 4.703 & 4.439 & $\mathrm{H}$ & 0.154 & 0.913 & -3.542 \\
\hline $\mathrm{N}$ & -0.160 & 7.191 & -3.133 & $\mathrm{H}$ & -2.044 & 5.476 & 4.859 & $\mathrm{H}$ & -1.457 & 4.396 & -3.260 \\
\hline C & -0.296 & 6.693 & -4.502 & $\mathrm{H}$ & -3.522 & 4.551 & 5.154 & $\mathrm{H}$ & -1.672 & 3.756 & -4.913 \\
\hline $\mathrm{H}$ & -0.273 & 7.531 & -5.213 & $\mathrm{~N}$ & -1.927 & 3.455 & 4.436 & $\mathrm{H}$ & 2.766 & 0.931 & 3.181 \\
\hline $\mathrm{N}$ & -1.451 & 5.856 & -4.814 & & & & & & & & \\
\hline
\end{tabular}




\begin{tabular}{|c|c|c|c|c|c|c|c|c|c|c|c|}
\hline \multicolumn{12}{|c|}{ CB[7] } \\
\hline $\mathrm{O}$ & 0.122 & 0.006 & 0.018 & $\mathrm{~N}$ & -5.164 & -7.422 & 2.243 & C & 3.707 & -8.236 & -1.182 \\
\hline C & 0.080 & 0.002 & 1.232 & C & -5.923 & -6.943 & 1.101 & $\mathrm{H}$ & 4.538 & -8.931 & -1.386 \\
\hline $\mathrm{N}$ & 1.172 & 0.047 & 2.094 & $\mathrm{H}$ & -6.851 & -7.527 & 0.995 & $\mathrm{H}$ & 3.422 & -7.720 & -2.102 \\
\hline C & 0.786 & 0.182 & 3.479 & $\mathrm{~N}$ & -5.233 & -6.882 & -0.166 & C & 4.054 & -9.475 & 2.185 \\
\hline $\mathrm{H}$ & 1.271 & 1.068 & 3.918 & C & -4.966 & -5.578 & -0.572 & $\mathrm{H}$ & 3.946 & -9.669 & 3.255 \\
\hline $\mathrm{N}$ & 0.996 & -0.971 & 4.335 & $\mathrm{O}$ & -4.480 & -5.243 & -1.634 & $\mathrm{H}$ & 4.852 & -10.106 & 1.767 \\
\hline C & -0.181 & -1.380 & 4.961 & C & -4.946 & -8.020 & -1.010 & $\mathrm{~N}$ & 4.436 & -8.084 & 2.051 \\
\hline $\mathrm{O}$ & -0.274 & -2.181 & 5.870 & $\mathrm{H}$ & -5.832 & -8.673 & -1.031 & C & 5.037 & -7.505 & 0.871 \\
\hline $\mathrm{N}$ & -1.225 & -0.657 & 4.393 & $\mathrm{H}$ & -4.745 & -7.635 & -2.013 & $\mathrm{H}$ & 5.880 & -8.130 & 0.535 \\
\hline C & -0.774 & 0.301 & 3.412 & C & -4.903 & -8.826 & 2.495 & $\mathrm{~N}$ & 4.156 & -7.227 & -0.246 \\
\hline $\mathrm{H}$ & -1.144 & 1.306 & 3.672 & $\mathrm{H}$ & -4.685 & -8.921 & 3.562 & C & 4.163 & -5.879 & -0.603 \\
\hline $\mathrm{N}$ & -1.071 & 0.010 & 2.020 & $\mathrm{H}$ & -5.800 & -9.413 & 2.244 & $\mathrm{O}$ & 3.666 & -5.396 & -1.600 \\
\hline C & -2.369 & 0.244 & 1.416 & $\mathrm{~N}$ & -3.773 & -9.373 & 1.778 & $\mathrm{~N}$ & 4.895 & -5.198 & 0.366 \\
\hline $\mathrm{H}$ & -2.786 & 1.187 & 1.804 & C & -3.814 & -9.823 & 0.405 & C & 5.479 & -6.079 & 1.350 \\
\hline $\mathrm{H}$ & -2.206 & 0.327 & 0.339 & $\mathrm{H}$ & -4.683 & -10.482 & 0.253 & $\mathrm{H}$ & 6.573 & -5.948 & 1.367 \\
\hline C & -2.589 & -0.795 & 4.852 & $\mathrm{~N}$ & -3.787 & -8.799 & -0.621 & $\mathrm{~N}$ & 4.952 & -5.999 & 2.699 \\
\hline $\mathrm{H}$ & -2.556 & -1.333 & 5.802 & C & -2.698 & -8.939 & -1.480 & $\mathrm{C}$ & 4.459 & -7.224 & 3.145 \\
\hline $\mathrm{H}$ & -3.011 & 0.210 & 5.006 & $\mathrm{O}$ & -2.533 & -8.357 & -2.534 & $\mathrm{O}$ & 4.152 & -7.504 & 4.287 \\
\hline $\mathrm{N}$ & -3.461 & -1.551 & 3.974 & $\mathrm{~N}$ & -1.863 & -9.910 & -0.935 & $\mathrm{C}$ & 5.321 & -4.962 & 3.643 \\
\hline C & -4.128 & -0.979 & 2.818 & C & -2.442 & -10.559 & 0.221 & $\mathrm{H}$ & 5.109 & -5.354 & 4.641 \\
\hline $\mathrm{H}$ & -4.598 & -0.022 & 3.094 & $\mathrm{H}$ & -2.552 & -11.638 & 0.029 & $\mathrm{H}$ & 6.397 & -4.749 & 3.547 \\
\hline $\mathrm{N}$ & -3.336 & -0.810 & 1.622 & $\mathrm{~N}$ & -1.775 & -10.352 & 1.491 & C & 5.187 & -3.788 & 0.250 \\
\hline C & -3.729 & -1.656 & 0.590 & C & -2.602 & -9.741 & 2.432 & $\mathrm{H}$ & 6.268 & -3.639 & 0.394 \\
\hline $\mathrm{O}$ & -3.308 & -1.643 & -0.550 & $\mathrm{O}$ & -2.364 & -9.601 & 3.616 & $\mathrm{H}$ & 4.902 & -3.480 & -0.760 \\
\hline $\mathrm{N}$ & -4.735 & -2.480 & 1.090 & C & -0.580 & -11.059 & 1.896 & $\mathrm{~N}$ & 4.459 & -2.935 & 1.169 \\
\hline C & -5.166 & -2.083 & 2.416 & $\mathrm{H}$ & -0.537 & -11.024 & 2.988 & C & 4.882 & -2.691 & 2.538 \\
\hline $\mathrm{H}$ & -6.202 & -1.711 & 2.377 & $\mathrm{H}$ & -0.651 & -12.106 & 1.559 & $\mathrm{H}$ & 5.956 & -2.447 & 2.560 \\
\hline $\mathrm{N}$ & -5.037 & -3.067 & 3.467 & C & -0.684 & -10.378 & -1.633 & $\mathrm{~N}$ & 4.593 & -3.721 & 3.508 \\
\hline $\mathrm{C}$ & -4.089 & -2.712 & 4.423 & $\mathrm{H}$ & -0.736 & -11.472 & -1.730 & C & 3.588 & -3.355 & 4.399 \\
\hline $\mathrm{O}$ & -3.882 & -3.281 & 5.476 & $\mathrm{H}$ & -0.700 & -9.915 & -2.622 & $\mathrm{O}$ & 3.212 & -3.997 & 5.360 \\
\hline C & -5.943 & -4.178 & 3.670 & $\mathrm{~N}$ & 0.580 & -10.031 & -1.020 & $\mathrm{~N}$ & 3.134 & -2.094 & 4.018 \\
\hline $\mathrm{H}$ & -5.802 & -4.517 & 4.699 & C & 1.190 & -10.739 & 0.080 & C & 3.969 & -1.500 & 2.988 \\
\hline $\mathrm{H}$ & -6.975 & -3.827 & 3.529 & $\mathrm{H}$ & 1.188 & -11.822 & -0.123 & $\mathrm{H}$ & 4.535 & -0.653 & 3.407 \\
\hline $\mathrm{C}$ & -5.528 & -3.304 & 0.203 & $\mathrm{~N}$ & 0.656 & -10.483 & 1.408 & $\mathrm{~N}$ & 3.314 & -1.097 & 1.766 \\
\hline $\mathrm{H}$ & -6.586 & -3.008 & 0.287 & C & 1.650 & -10.086 & 2.302 & C & 3.648 & -1.908 & 0.685 \\
\hline $\mathrm{H}$ & -5.171 & -3.118 & -0.814 & $\mathrm{O}$ & 1.547 & -10.015 & 3.510 & $\mathrm{O}$ & 3.332 & -1.726 & -0.474 \\
\hline $\mathrm{N}$ & -5.412 & -4.728 & 0.439 & $\mathrm{~N}$ & 2.802 & -9.841 & 1.558 & C & 2.533 & 0.111 & 1.603 \\
\hline C & -6.179 & -5.436 & 1.448 & C & 2.630 & -10.128 & 0.155 & $\mathrm{H}$ & 3.052 & 0.937 & 2.108 \\
\hline $\mathrm{H}$ & -7.240 & -5.150 & 1.383 & $\mathrm{H}$ & 3.415 & -10.823 & -0.185 & $\mathrm{H}$ & 2.473 & 0.308 & 0.530 \\
\hline $\mathrm{N}$ & -5.723 & -5.324 & 2.814 & $\mathrm{~N}$ & 2.550 & -8.990 & -0.746 & C & 2.284 & -1.321 & 4.898 \\
\hline C & -5.173 & -6.508 & 3.297 & C & 1.395 & -9.022 & -1.527 & $\mathrm{H}$ & 2.093 & -1.936 & 5.781 \\
\hline $\mathrm{O}$ & -4.813 & -6.720 & 4.438 & $\mathrm{O}$ & 1.164 & -8.334 & -2.500 & $\mathrm{H}$ & 2.811 & -0.398 & 5.193 \\
\hline
\end{tabular}




\begin{tabular}{|c|c|c|c|c|c|c|c|c|c|c|c|}
\hline \multicolumn{12}{|c|}{ CB[7]-H ${ }^{+} \_N 2$} \\
\hline $\mathrm{O}$ & -0.289 & -0.070 & -0.073 & $\mathrm{C}$ & -5.990 & -6.826 & 0.618 & $\mathrm{H}$ & 4.951 & -9.134 & -1.245 \\
\hline $\mathrm{C}$ & -0.173 & -0.083 & 1.126 & $\mathrm{H}$ & -6.881 & -7.330 & 0.216 & $\mathrm{H}$ & 4.114 & -7.935 & -2.283 \\
\hline $\mathrm{N}$ & 0.999 & -0.280 & 1.870 & $\mathrm{~N}$ & -5.080 & -6.480 & -0.463 & $\mathrm{C}$ & 3.628 & -9.127 & 2.213 \\
\hline $\mathrm{C}$ & 0.799 & 0.120 & 3.246 & $\mathrm{C}$ & -5.038 & -5.112 & -0.695 & $\mathrm{H}$ & 3.285 & -9.177 & 3.249 \\
\hline $\mathrm{H}$ & 1.200 & 1.126 & 3.438 & $\mathrm{O}$ & -4.506 & -4.541 & -1.626 & $\mathrm{H}$ & 4.439 & -9.856 & 2.056 \\
\hline $\mathrm{N}$ & 1.289 & -0.777 & 4.285 & $\mathrm{C}$ & -4.684 & -7.415 & -1.504 & $\mathrm{~N}$ & 4.151 & -7.789 & 1.999 \\
\hline $\mathrm{C}$ & 0.344 & -1.529 & 4.892 & $\mathrm{H}$ & -5.560 & -8.015 & -1.796 & $\mathrm{C}$ & 5.096 & -7.464 & 0.941 \\
\hline $\mathrm{O}$ & 0.354 & -2.245 & 5.847 & $\mathrm{H}$ & -4.345 & -6.819 & -2.355 & $\mathrm{H}$ & 5.904 & -8.210 & 0.916 \\
\hline $\mathrm{N}$ & -0.961 & -1.297 & 4.073 & $\mathrm{C}$ & -5.182 & -9.026 & 1.680 & $\mathrm{~N}$ & 4.548 & -7.283 & -0.384 \\
\hline $\mathrm{C}$ & -0.741 & 0.064 & 3.377 & $\mathrm{H}$ & -5.108 & -9.358 & 2.718 & $\mathrm{C}$ & 4.551 & -5.956 & -0.791 \\
\hline $\mathrm{H}$ & -1.158 & 0.812 & 4.057 & $\mathrm{H}$ & -6.034 & -9.517 & 1.191 & $\mathrm{O}$ & 4.237 & -5.529 & -1.883 \\
\hline $\mathrm{N}$ & -1.215 & 0.136 & 2.059 & $\mathrm{~N}$ & -3.960 & -9.423 & 1.022 & $\mathrm{~N}$ & 5.037 & -5.196 & 0.279 \\
\hline $\mathrm{C}$ & -2.618 & 0.297 & 1.676 & $\mathrm{C}$ & -3.789 & -9.537 & -0.408 & $\mathrm{C}$ & 5.590 & -6.030 & 1.332 \\
\hline $\mathrm{H}$ & -3.025 & 1.154 & 2.229 & $\mathrm{H}$ & -4.623 & -10.109 & -0.845 & $\mathrm{H}$ & 6.687 & -5.939 & 1.356 \\
\hline $\mathrm{H}$ & -2.623 & 0.509 & 0.604 & $\mathrm{~N}$ & -3.600 & -8.296 & -1.138 & $\mathrm{~N}$ & 5.045 & -5.838 & 2.654 \\
\hline $\mathrm{C}$ & -2.255 & -1.468 & 4.887 & $\mathrm{C}$ & -2.402 & -8.282 & -1.855 & $\mathrm{C}$ & 4.201 & -6.878 & 3.047 \\
\hline $\mathrm{H}$ & -2.028 & -2.206 & 5.662 & $\mathrm{O}$ & -2.069 & -7.451 & -2.676 & $\mathrm{O}$ & 3.653 & -6.976 & 4.127 \\
\hline $\mathrm{H}$ & -2.462 & -0.488 & 5.331 & $\mathrm{~N}$ & -1.689 & -9.418 & -1.492 & $\mathrm{C}$ & 5.386 & -4.761 & 3.543 \\
\hline $\mathrm{N}$ & -3.299 & -1.962 & 4.082 & $\mathrm{C}$ & -2.404 & -10.253 & -0.555 & $\mathrm{H}$ & 5.139 & -5.079 & 4.558 \\
\hline $\mathrm{C}$ & -4.098 & -1.198 & 3.131 & $\mathrm{H}$ & -2.484 & -11.277 & -0.949 & $\mathrm{H}$ & 6.464 & -4.561 & 3.466 \\
\hline $\mathrm{H}$ & -4.504 & -0.296 & 3.610 & $\mathrm{~N}$ & -1.898 & -10.283 & 0.808 & $\mathrm{C}$ & 5.397 & -3.811 & 0.085 \\
\hline $\mathrm{N}$ & -3.435 & -0.874 & 1.887 & $\mathrm{C}$ & -2.867 & -9.912 & 1.736 & $\mathrm{H}$ & 6.473 & -3.670 & 0.264 \\
\hline $\mathrm{C}$ & -4.060 & -1.493 & 0.781 & $\mathrm{O}$ & -2.797 & -10.032 & 2.943 & $\mathrm{H}$ & 5.161 & -3.566 & -0.953 \\
\hline $\mathrm{O}$ & -3.817 & -1.246 & -0.378 & $\mathrm{C}$ & -0.751 & -11.072 & 1.218 & $\mathrm{~N}$ & 4.676 & -2.869 & 0.928 \\
\hline $\mathrm{N}$ & -5.003 & -2.375 & 1.280 & $\mathrm{H}$ & -0.831 & -11.203 & 2.300 & $\mathrm{C}$ & 5.025 & -2.539 & 2.290 \\
\hline $\mathrm{C}$ & -5.207 & -2.229 & 2.708 & $\mathrm{H}$ & -0.786 & -12.053 & 0.721 & $\mathrm{H}$ & 6.097 & -2.308 & 2.360 \\
\hline $\mathrm{H}$ & -6.226 & -1.869 & 2.910 & $\mathrm{C}$ & -0.443 & -9.777 & -2.133 & $\mathrm{~N}$ & 4.660 & -3.513 & 3.314 \\
\hline $\mathrm{N}$ & -4.934 & -3.395 & 3.529 & $\mathrm{H}$ & -0.494 & -10.837 & -2.425 & $\mathrm{C}$ & 3.871 & -2.966 & 4.306 \\
\hline $\mathrm{C}$ & -3.832 & -3.253 & 4.333 & $\mathrm{H}$ & -0.343 & -9.153 & -3.025 & $\mathrm{O}$ & 3.534 & -3.467 & 5.359 \\
\hline $\mathrm{O}$ & -3.379 & -4.028 & 5.148 & $\mathrm{~N}$ & 0.744 & -9.553 & -1.330 & $\mathrm{~N}$ & 3.546 & -1.657 & 3.904 \\
\hline $\mathrm{C}$ & -5.802 & -4.568 & 3.616 & $\mathrm{C}$ & 1.213 & -10.494 & -0.325 & $\mathrm{C}$ & 4.106 & -1.312 & 2.615 \\
\hline $\mathrm{H}$ & -5.560 & -5.079 & 4.551 & $\mathrm{H}$ & 1.210 & -11.517 & -0.733 & $\mathrm{H}$ & 4.655 & -0.361 & 2.681 \\
\hline $\mathrm{H}$ & -6.842 & -4.213 & 3.645 & $\mathrm{~N}$ & 0.536 & -10.469 & 0.950 & $\mathrm{~N}$ & 3.178 & -1.294 & 1.500 \\
\hline $\mathrm{C}$ & -5.929 & -3.068 & 0.384 & $\mathrm{C}$ & 1.297 & -9.877 & 1.951 & $\mathrm{C}$ & 3.597 & -2.143 & 0.457 \\
\hline $\mathrm{H}$ & -6.957 & -2.831 & 0.690 & $\mathrm{O}$ & 0.990 & -9.771 & 3.122 & $\mathrm{O}$ & 3.113 & -2.178 & -0.653 \\
\hline $\mathrm{H}$ & -5.739 & -2.673 & -0.617 & $\mathrm{~N}$ & 2.502 & -9.473 & 1.374 & $\mathrm{C}$ & 2.304 & -0.192 & 1.205 \\
\hline $\mathrm{N}$ & -5.772 & -4.495 & 0.323 & $\mathrm{C}$ & 2.647 & -9.967 & 0.014 & $\mathrm{H}$ & 2.785 & 0.760 & 1.482 \\
\hline $\mathrm{C}$ & -6.308 & -5.439 & 1.271 & $\mathrm{H}$ & 3.419 & -10.750 & -0.025 & $\mathrm{H}$ & 2.103 & -0.202 & 0.130 \\
\hline $\mathrm{H}$ & -7.384 & -5.264 & 1.421 & $\mathrm{~N}$ & 2.891 & -8.978 & -1.009 & $\mathrm{C}$ & 2.716 & -0.831 & 4.713 \\
\hline $\mathrm{N}$ & -5.626 & -5.523 & 2.554 & $\mathrm{C}$ & 1.781 & -8.759 & -1.822 & $\mathrm{H}$ & 2.723 & -1.239 & 5.726 \\
\hline $\mathrm{C}$ & -5.244 & -6.839 & 2.856 & $\mathrm{O}$ & 1.741 & -8.044 & -2.802 & $\mathrm{H}$ & 3.081 & 0.202 & 4.719 \\
\hline $\mathrm{O}$ & -4.859 & -7.233 & 3.938 & $\mathrm{C}$ & 4.171 & -8.362 & -1.279 & $\mathrm{H}$ & -0.979 & -2.029 & 3.349 \\
\hline $\mathrm{N}$ & -5.440 & -7.595 & 1.712 & & & & & & & & \\
\hline
\end{tabular}




\begin{tabular}{|c|c|c|c|c|c|c|c|c|c|c|c|}
\hline \multicolumn{12}{|c|}{ CB[7]-H+_N4 } \\
\hline $\mathrm{O}$ & 0.229 & -0.053 & -0.056 & $\mathrm{C}$ & -5.880 & -6.876 & 0.977 & $\mathrm{H}$ & 4.651 & -8.583 & -1.847 \\
\hline $\mathrm{C}$ & 0.125 & -0.078 & 1.143 & $\mathrm{H}$ & -6.762 & -7.533 & 0.953 & $\mathrm{H}$ & 3.564 & -7.269 & -2.406 \\
\hline $\mathrm{N}$ & 1.195 & 0.004 & 2.067 & $\mathrm{~N}$ & -5.313 & -6.758 & -0.347 & $\mathrm{C}$ & 4.216 & -9.521 & 1.633 \\
\hline $\mathrm{C}$ & 0.729 & -0.040 & 3.390 & $\mathrm{C}$ & -5.162 & -5.438 & -0.752 & $\mathrm{H}$ & 4.125 & -9.840 & 2.674 \\
\hline $\mathrm{H}$ & 1.236 & 0.643 & 4.078 & $\mathrm{O}$ & -4.792 & -5.049 & -1.840 & $\mathrm{H}$ & 5.005 & -10.098 & 1.132 \\
\hline $\mathrm{N}$ & 0.799 & -1.431 & 4.057 & $\mathrm{C}$ & -5.053 & -7.871 & -1.241 & $\mathrm{~N}$ & 4.616 & -8.123 & 1.654 \\
\hline $\mathrm{C}$ & -0.518 & -1.532 & 4.885 & $\mathrm{H}$ & -5.910 & -8.557 & -1.203 & $\mathrm{C}$ & 5.233 & -7.419 & 0.551 \\
\hline $\mathrm{O}$ & -0.603 & -2.269 & 5.820 & $\mathrm{H}$ & -4.954 & -7.455 & -2.247 & $\mathrm{H}$ & 6.066 & -8.013 & 0.147 \\
\hline $\mathrm{N}$ & -1.374 & -0.659 & 4.309 & $\mathrm{C}$ & -4.585 & -8.675 & 2.254 & $\mathrm{~N}$ & 4.353 & -6.993 & -0.527 \\
\hline $\mathrm{C}$ & -0.795 & 0.194 & 3.278 & $\mathrm{H}$ & -4.244 & -8.754 & 3.289 & $\mathrm{C}$ & 4.428 & -5.626 & -0.758 \\
\hline $\mathrm{H}$ & -1.076 & 1.236 & 3.491 & $\mathrm{H}$ & -5.463 & -9.323 & 2.102 & $\mathrm{O}$ & 3.938 & -5.011 & -1.683 \\
\hline $\mathrm{N}$ & -1.054 & -0.159 & 1.898 & $\mathrm{~N}$ & -3.501 & -9.130 & 1.412 & $\mathrm{~N}$ & 5.223 & -5.077 & 0.253 \\
\hline $\mathrm{C}$ & -2.348 & 0.087 & 1.251 & $\mathrm{C}$ & -3.699 & -9.617 & 0.056 & $\mathrm{C}$ & 5.692 & -6.065 & 1.191 \\
\hline $\mathrm{H}$ & -2.718 & 1.079 & 1.554 & $\mathrm{H}$ & -4.548 & -10.317 & 0.026 & $\mathrm{H}$ & 6.783 & -5.990 & 1.314 \\
\hline $\mathrm{H}$ & -2.159 & 0.078 & 0.174 & $\mathrm{~N}$ & -3.844 & -8.616 & -0.973 & $\mathrm{~N}$ & 5.039 & -6.083 & 2.491 \\
\hline $\mathrm{C}$ & -2.795 & -0.561 & 4.748 & $\mathrm{C}$ & -2.726 & -8.530 & -1.801 & $\mathrm{C}$ & 4.528 & -7.353 & 2.802 \\
\hline $\mathrm{H}$ & -2.841 & -0.977 & 5.757 & $\mathrm{O}$ & -2.620 & -7.837 & -2.792 & $\mathrm{O}$ & 4.131 & -7.706 & 3.893 \\
\hline $\mathrm{H}$ & -3.043 & 0.506 & 4.767 & $\mathrm{~N}$ & -1.775 & -9.425 & -1.308 & $\mathrm{C}$ & 5.329 & -5.148 & 3.545 \\
\hline $\mathrm{N}$ & -3.715 & -1.284 & 3.938 & $\mathrm{C}$ & -2.328 & -10.294 & -0.282 & $\mathrm{H}$ & 5.064 & -5.634 & 4.487 \\
\hline C & -4.248 & -0.862 & 2.659 & $\mathrm{H}$ & -2.433 & -11.319 & -0.669 & $\mathrm{H}$ & 6.397 & -4.889 & 3.546 \\
\hline $\mathrm{H}$ & -4.699 & 0.137 & 2.746 & $\mathrm{~N}$ & -1.641 & -10.313 & 0.987 & $\mathrm{C}$ & 5.510 & -3.670 & 0.307 \\
\hline $\mathrm{N}$ & -3.334 & -0.918 & 1.535 & $\mathrm{C}$ & -2.337 & -9.643 & 1.987 & $\mathrm{H}$ & 6.561 & -3.526 & 0.589 \\
\hline $\mathrm{C}$ & -3.826 & -1.726 & 0.494 & $\mathrm{O}$ & -2.015 & -9.557 & 3.156 & $\mathrm{H}$ & 5.334 & -3.260 & -0.691 \\
\hline $\mathrm{O}$ & -3.347 & -1.804 & -0.616 & $\mathrm{C}$ & -0.427 & -11.050 & 1.258 & $\mathrm{~N}$ & 4.668 & -2.896 & 1.222 \\
\hline $\mathrm{N}$ & -4.965 & -2.354 & 0.966 & $\mathrm{H}$ & -0.350 & -11.165 & 2.342 & C & 4.924 & -2.766 & 2.644 \\
\hline $\mathrm{C}$ & -5.291 & -1.986 & 2.324 & $\mathrm{H}$ & -0.507 & -12.039 & 0.785 & $\mathrm{H}$ & 5.976 & -2.499 & 2.818 \\
\hline $\mathrm{H}$ & -6.333 & -1.640 & 2.382 & $\mathrm{C}$ & -0.628 & -9.787 & -2.120 & $\mathrm{~N}$ & 4.570 & -3.900 & 3.477 \\
\hline $\mathrm{N}$ & -5.046 & -2.992 & 3.352 & $\mathrm{H}$ & -0.698 & -10.849 & -2.400 & $\mathrm{C}$ & 3.481 & -3.672 & 4.280 \\
\hline C & -4.198 & -2.542 & 4.343 & $\mathrm{H}$ & -0.668 & -9.165 & -3.017 & $\mathrm{O}$ & 2.971 & -4.408 & 5.097 \\
\hline $\mathrm{O}$ & -3.927 & -3.077 & 5.398 & $\mathrm{~N}$ & 0.657 & -9.562 & -1.494 & $\mathrm{~N}$ & 3.050 & -2.344 & 4.024 \\
\hline $\mathrm{C}$ & -5.906 & -4.152 & 3.574 & $\mathrm{C}$ & 1.284 & -10.455 & -0.549 & $\mathrm{C}$ & 3.923 & -1.640 & 3.091 \\
\hline $\mathrm{H}$ & -5.706 & -4.494 & 4.593 & $\mathrm{H}$ & 1.244 & -11.489 & -0.924 & $\mathrm{H}$ & 4.417 & -0.795 & 3.592 \\
\hline $\mathrm{H}$ & -6.955 & -3.836 & 3.486 & $\mathrm{~N}$ & 0.795 & -10.402 & 0.820 & $\mathrm{~N}$ & 3.301 & -1.222 & 1.857 \\
\hline $\mathrm{C}$ & -5.776 & -3.214 & 0.117 & $\mathrm{C}$ & 1.815 & -10.136 & 1.731 & $\mathrm{C}$ & 3.828 & -1.907 & 0.740 \\
\hline $\mathrm{H}$ & -6.832 & -2.958 & 0.285 & $\mathrm{O}$ & 1.747 & -10.226 & 2.941 & $\mathrm{O}$ & 3.596 & -1.630 & -0.415 \\
\hline $\mathrm{H}$ & -5.504 & -2.997 & -0.919 & $\mathrm{~N}$ & 2.950 & -9.797 & 0.996 & C & 2.603 & 0.027 & 1.669 \\
\hline $\mathrm{N}$ & -5.569 & -4.628 & 0.316 & $\mathrm{C}$ & 2.743 & -9.897 & -0.430 & $\mathrm{H}$ & 3.101 & 0.830 & 2.228 \\
\hline $\mathrm{C}$ & -6.222 & -5.397 & 1.362 & $\mathrm{H}$ & 3.500 & -10.560 & -0.877 & $\mathrm{H}$ & 2.618 & 0.252 & 0.600 \\
\hline $\mathrm{H}$ & -7.303 & -5.189 & 1.372 & $\mathrm{~N}$ & 2.679 & -8.645 & -1.164 & $\mathrm{C}$ & 2.071 & -1.761 & 4.854 \\
\hline $\mathrm{N}$ & -5.676 & -5.263 & 2.690 & $\mathrm{C}$ & 1.484 & -8.511 & -1.874 & $\mathrm{H}$ & 1.773 & -2.490 & 5.613 \\
\hline $\mathrm{C}$ & -4.944 & -6.383 & 3.088 & $\mathrm{O}$ & 1.235 & -7.659 & -2.703 & $\mathrm{H}$ & 2.384 & -0.820 & 5.320 \\
\hline $\mathrm{O}$ & -4.417 & -6.535 & 4.173 & $\mathrm{C}$ & 3.848 & -7.890 & -1.552 & $\mathrm{H}$ & 0.728 & -2.145 & 3.318 \\
\hline $\mathrm{N}$ & -4.976 & -7.293 & 2.039 & & & & & & & & \\
\hline
\end{tabular}




\begin{tabular}{|c|c|c|c|c|c|c|c|c|c|c|c|}
\hline \multicolumn{12}{|c|}{ CB[7]A } \\
\hline $\mathrm{C}$ & 0.000 & -0.005 & -0.003 & $\mathrm{H}$ & 0.327 & 9.009 & -5.270 & $\mathrm{H}$ & -5.112 & 1.685 & 4.558 \\
\hline $\mathrm{N}$ & 0.004 & -0.008 & 1.452 & $\mathrm{~N}$ & -1.103 & 8.985 & -3.790 & $\mathrm{H}$ & -5.367 & 1.234 & 2.864 \\
\hline $\mathrm{C}$ & 1.381 & -0.012 & 1.955 & $\mathrm{C}$ & -2.249 & 8.482 & -4.538 & $\mathrm{~N}$ & -3.418 & 1.807 & 3.343 \\
\hline $\mathrm{H}$ & 1.566 & -0.925 & 2.539 & $\mathrm{H}$ & -2.270 & 8.977 & -5.520 & $\mathrm{C}$ & -2.560 & 1.770 & 4.530 \\
\hline $\mathrm{N}$ & 1.825 & 1.136 & 2.736 & $\mathrm{~N}$ & -2.379 & 7.032 & -4.705 & $\mathrm{H}$ & -3.117 & 1.358 & 5.385 \\
\hline $\mathrm{C}$ & 2.094 & 2.205 & 1.773 & $\mathrm{C}$ & -3.586 & 6.557 & -4.047 & $\mathrm{~N}$ & -1.918 & 3.009 & 4.949 \\
\hline $\mathrm{N}$ & 2.596 & 1.501 & 0.604 & $\mathrm{~N}$ & -4.391 & 7.767 & -3.876 & $\mathrm{C}$ & -0.786 & 3.211 & 4.044 \\
\hline $\mathrm{C}$ & 2.235 & 0.082 & 0.671 & C & -3.448 & 8.852 & -3.637 & $\mathrm{~N}$ & -0.327 & 1.861 & 3.757 \\
\hline $\mathrm{H}$ & 3.144 & -0.537 & 0.703 & $\mathrm{H}$ & -3.928 & 9.801 & -3.915 & $\mathrm{C}$ & -1.370 & 0.887 & 4.090 \\
\hline $\mathrm{N}$ & 1.349 & -0.448 & -0.358 & $\mathrm{~N}$ & -2.852 & 8.962 & -2.302 & $\mathrm{H}$ & -1.013 & 0.209 & 4.878 \\
\hline $\mathrm{C}$ & 1.753 & -0.300 & -1.749 & $\mathrm{C}$ & -1.412 & 8.773 & -2.376 & $\mathrm{~N}$ & -1.932 & 0.087 & 3.009 \\
\hline $\mathrm{H}$ & 2.708 & -0.837 & -1.854 & $\mathrm{C}$ & -3.443 & 9.878 & -1.344 & $\mathrm{C}$ & -2.868 & 0.959 & 2.297 \\
\hline $\mathrm{H}$ & 1.009 & -0.835 & -2.354 & $\mathrm{H}$ & -2.644 & 10.447 & -0.851 & $\mathrm{C}$ & -1.018 & -0.711 & 2.205 \\
\hline $\mathrm{C}$ & 3.849 & 1.879 & -0.023 & $\mathrm{H}$ & -4.077 & 10.600 & -1.881 & $\mathrm{H}$ & -0.532 & -1.416 & 2.896 \\
\hline $\mathrm{H}$ & 4.355 & 2.624 & 0.606 & C & -5.561 & 7.676 & -3.013 & $\mathrm{H}$ & -1.634 & -1.301 & 1.513 \\
\hline $\mathrm{H}$ & 4.504 & 0.997 & -0.078 & $\mathrm{H}$ & -6.121 & 8.613 & -3.151 & $\mathrm{C}$ & 1.064 & 1.486 & 3.928 \\
\hline $\mathrm{N}$ & 3.791 & 2.433 & -1.369 & $\mathrm{H}$ & -6.184 & 6.862 & -3.407 & $\mathrm{H}$ & 1.601 & 2.309 & 4.417 \\
\hline C & 3.258 & 1.591 & -2.433 & $\mathrm{~N}$ & -5.340 & 7.460 & -1.596 & $\mathrm{H}$ & 1.121 & 0.614 & 4.598 \\
\hline $\mathrm{H}$ & 3.972 & 0.777 & -2.626 & $\mathrm{C}$ & -5.478 & 8.592 & -0.676 & $\mathrm{H}$ & 1.181 & 2.784 & 1.539 \\
\hline $\mathrm{N}$ & 1.908 & 1.046 & -2.267 & $\mathrm{H}$ & -6.203 & 9.317 & -1.074 & $\mathrm{H}$ & 2.846 & 2.902 & 2.174 \\
\hline C & 1.025 & 1.563 & -3.301 & $\mathrm{~N}$ & -4.270 & 9.311 & -0.288 & $\mathrm{H}$ & -0.750 & -0.703 & -0.402 \\
\hline $\mathrm{N}$ & 1.942 & 2.059 & -4.328 & C & -3.600 & 8.472 & 0.707 & $\mathrm{H}$ & -0.218 & 1.001 & -0.407 \\
\hline $\mathrm{C}$ & 3.107 & 2.572 & -3.617 & $\mathrm{~N}$ & -4.696 & 7.843 & 1.427 & $\mathrm{H}$ & -3.654 & 0.362 & 1.812 \\
\hline $\mathrm{H}$ & 3.967 & 2.566 & -4.303 & C & -5.932 & 7.930 & 0.644 & $\mathrm{H}$ & -2.359 & 1.554 & 1.517 \\
\hline $\mathrm{N}$ & 2.995 & 3.879 & -2.966 & $\mathrm{H}$ & -6.684 & 8.517 & 1.192 & $\mathrm{H}$ & -6.169 & 3.175 & 1.283 \\
\hline C & 3.153 & 3.740 & -1.526 & $\mathrm{~N}$ & -6.547 & 6.686 & 0.199 & $\mathrm{H}$ & -4.443 & 3.613 & 1.413 \\
\hline C & 3.473 & 5.056 & -3.666 & C & -5.759 & 6.228 & -0.945 & $\mathrm{H}$ & -6.377 & 5.612 & -1.616 \\
\hline $\mathrm{H}$ & 4.061 & 5.673 & -2.973 & C & -6.888 & 5.696 & 1.212 & $\mathrm{H}$ & -4.891 & 5.621 & -0.625 \\
\hline $\mathrm{H}$ & 4.148 & 4.740 & -4.477 & $\mathrm{H}$ & -7.610 & 6.181 & 1.888 & $\mathrm{H}$ & -3.359 & 6.079 & -3.076 \\
\hline $\mathrm{C}$ & 1.371 & 2.884 & -5.385 & $\mathrm{H}$ & -7.417 & 4.883 & 0.697 & $\mathrm{H}$ & -4.120 & 5.825 & -4.671 \\
\hline $\mathrm{H}$ & 2.164 & 3.015 & -6.137 & C & -4.775 & 7.899 & 2.874 & $\mathrm{H}$ & -1.021 & 4.612 & -4.098 \\
\hline $\mathrm{H}$ & 0.571 & 2.293 & -5.851 & $\mathrm{H}$ & -4.003 & 8.582 & 3.251 & $\mathrm{H}$ & -1.118 & 3.677 & -5.617 \\
\hline $\mathrm{N}$ & 0.849 & 4.186 & -5.017 & $\mathrm{H}$ & -5.752 & 8.316 & 3.164 & $\mathrm{H}$ & 0.372 & 2.368 & -2.914 \\
\hline C & 1.637 & 5.382 & -5.327 & $\mathrm{~N}$ & -4.628 & 6.650 & 3.609 & $\mathrm{H}$ & 0.382 & 0.770 & -3.711 \\
\hline $\mathrm{H}$ & 2.257 & 5.204 & -6.217 & $\mathrm{C}$ & -5.614 & 5.601 & 3.376 & $\mathrm{H}$ & -0.001 & 3.803 & 4.538 \\
\hline $\mathrm{N}$ & 2.483 & 5.933 & -4.275 & $\mathrm{H}$ & -6.575 & 5.923 & 3.803 & $\mathrm{H}$ & -1.087 & 3.743 & 3.122 \\
\hline $\mathrm{C}$ & 1.592 & 6.665 & -3.374 & $\mathrm{~N}$ & -5.807 & 5.135 & 2.000 & $\mathrm{H}$ & -2.592 & 6.559 & 4.176 \\
\hline $\mathrm{N}$ & 0.568 & 7.201 & -4.256 & $\mathrm{C}$ & -5.436 & 3.734 & 1.885 & $\mathrm{H}$ & -2.926 & 5.934 & 2.537 \\
\hline $\mathrm{C}$ & 0.566 & 6.478 & -5.531 & $\mathrm{~N}$ & -5.441 & 3.255 & 3.267 & $\mathrm{H}$ & -2.984 & 9.090 & 1.377 \\
\hline $\mathrm{H}$ & 0.797 & 7.168 & -6.355 & C & -5.002 & 4.375 & 4.091 & $\mathrm{H}$ & -2.942 & 7.722 & 0.230 \\
\hline $\mathrm{N}$ & -0.627 & 5.717 & -5.884 & $\mathrm{H}$ & -5.383 & 4.229 & 5.112 & $\mathrm{H}$ & -1.117 & 7.762 & -2.039 \\
\hline $\mathrm{C}$ & -0.572 & 4.482 & -5.101 & $\mathrm{~N}$ & -3.570 & 4.681 & 4.130 & $\mathrm{H}$ & -0.880 & 9.508 & -1.754 \\
\hline $\mathrm{C}$ & -1.899 & 6.423 & -5.931 & C & -3.319 & 5.998 & 3.569 & $\mathrm{H}$ & 1.158 & 6.003 & -2.601 \\
\hline $\mathrm{H}$ & -1.793 & 7.202 & -6.701 & C & -2.769 & 4.160 & 5.221 & $\mathrm{H}$ & 2.140 & 7.470 & -2.863 \\
\hline $\mathrm{H}$ & -2.647 & 5.705 & -6.293 & $\mathrm{H}$ & -2.115 & 4.956 & 5.601 & $\mathrm{H}$ & 2.179 & 3.782 & -1.003 \\
\hline $\mathrm{C}$ & 0.228 & 8.611 & -4.248 & $\mathrm{H}$ & -3.437 & 3.863 & 6.045 & $\mathrm{H}$ & 3.796 & 4.534 & -1.117 \\
\hline $\mathrm{H}$ & 0.945 & 9.151 & -3.615 & $\mathrm{C}$ & -4.852 & 1.947 & 3.521 & & & & \\
\hline
\end{tabular}




\begin{tabular}{|c|c|c|c|c|c|c|c|c|c|c|c|}
\hline \multicolumn{12}{|c|}{ CB[7]A-H+_N2 } \\
\hline $\mathrm{C}$ & -0.067 & 0.009 & 0.045 & $\mathrm{H}$ & 0.301 & 9.064 & -5.367 & $\mathrm{H}$ & -5.158 & 1.730 & 4.615 \\
\hline $\mathrm{N}$ & -0.046 & -0.016 & 1.502 & $\mathrm{~N}$ & -1.129 & 9.062 & -3.883 & $\mathrm{H}$ & -5.391 & 1.246 & 2.930 \\
\hline $\mathrm{C}$ & 1.340 & -0.026 & 1.986 & $\mathrm{C}$ & -2.276 & 8.555 & -4.630 & $\mathrm{~N}$ & -3.432 & 1.767 & 3.435 \\
\hline $\mathrm{H}$ & 1.542 & -0.956 & 2.536 & $\mathrm{H}$ & -2.302 & 9.060 & -5.605 & $\mathrm{C}$ & -2.591 & 1.683 & 4.636 \\
\hline $\mathrm{N}$ & 1.779 & 1.101 & 2.796 & $\mathrm{~N}$ & -2.403 & 7.107 & -4.808 & $\mathrm{H}$ & -3.160 & 1.249 & 5.469 \\
\hline $\mathrm{C}$ & 2.029 & 2.204 & 1.867 & $\mathrm{C}$ & -3.607 & 6.612 & -4.174 & $\mathrm{~N}$ & -1.952 & 2.909 & 5.091 \\
\hline $\mathrm{N}$ & 2.508 & 1.548 & 0.661 & $\mathrm{~N}$ & -4.406 & 7.819 & -3.945 & $\mathrm{C}$ & -0.789 & 3.127 & 4.227 \\
\hline $\mathrm{C}$ & 2.173 & 0.118 & 0.696 & $\mathrm{C}$ & -3.474 & 8.913 & -3.722 & $\mathrm{~N}$ & -0.353 & 1.788 & 3.883 \\
\hline $\mathrm{H}$ & 3.093 & -0.484 & 0.700 & $\mathrm{H}$ & -3.962 & 9.860 & -3.991 & C & -1.403 & 0.808 & 4.180 \\
\hline $\mathrm{N}$ & 1.282 & -0.402 & -0.332 & $\mathrm{~N}$ & -2.868 & 9.020 & -2.386 & $\mathrm{H}$ & -1.056 & 0.106 & 4.952 \\
\hline $\mathrm{C}$ & 1.669 & -0.238 & -1.726 & $\mathrm{C}$ & -1.419 & 8.844 & -2.473 & $\mathrm{~N}$ & -1.963 & 0.039 & 3.076 \\
\hline $\mathrm{H}$ & 2.622 & -0.774 & -1.848 & $\mathrm{C}$ & -3.458 & 9.885 & -1.406 & C & -2.883 & 0.926 & 2.375 \\
\hline $\mathrm{H}$ & 0.920 & -0.766 & -2.329 & $\mathrm{H}$ & -2.685 & 10.480 & -0.904 & $\mathrm{C}$ & -1.049 & -0.746 & 2.252 \\
\hline C & 3.757 & 1.952 & 0.035 & $\mathrm{H}$ & -4.158 & 10.587 & -1.878 & $\mathrm{H}$ & -0.554 & -1.456 & 2.930 \\
\hline $\mathrm{H}$ & 4.248 & 2.703 & 0.667 & $\mathrm{C}$ & -5.571 & 7.713 & -3.108 & $\mathrm{H}$ & -1.668 & -1.332 & 1.561 \\
\hline $\mathrm{H}$ & 4.430 & 1.083 & -0.022 & $\mathrm{H}$ & -6.121 & 8.662 & -3.188 & C & 1.045 & 1.396 & 4.013 \\
\hline $\mathrm{N}$ & 3.689 & 2.507 & -1.308 & $\mathrm{H}$ & -6.211 & 6.927 & -3.527 & $\mathrm{H}$ & 1.590 & 2.194 & 4.534 \\
\hline $\mathrm{C}$ & 3.171 & 1.663 & -2.376 & $\mathrm{~N}$ & -5.362 & 7.412 & -1.678 & $\mathrm{H}$ & 1.103 & 0.495 & 4.642 \\
\hline $\mathrm{H}$ & 3.886 & 0.848 & -2.558 & $\mathrm{C}$ & -5.450 & 8.512 & -0.720 & $\mathrm{H}$ & 1.108 & 2.787 & 1.673 \\
\hline $\mathrm{N}$ & 1.816 & 1.118 & -2.224 & $\mathrm{H}$ & -6.176 & 9.272 & -1.041 & $\mathrm{H}$ & 2.785 & 2.888 & 2.280 \\
\hline $\mathrm{C}$ & 0.953 & 1.627 & -3.280 & $\mathrm{~N}$ & -4.222 & 9.208 & -0.334 & $\mathrm{H}$ & -0.810 & -0.697 & -0.357 \\
\hline $\mathrm{N}$ & 1.887 & 2.124 & -4.290 & $\mathrm{C}$ & -3.438 & 8.273 & 0.440 & $\mathrm{H}$ & -0.310 & 1.018 & -0.339 \\
\hline $\mathrm{C}$ & 3.038 & 2.640 & -3.563 & $\mathrm{~N}$ & -4.456 & 7.566 & 1.288 & $\mathrm{H}$ & -3.674 & 0.345 & 1.877 \\
\hline $\mathrm{H}$ & 3.909 & 2.635 & -4.232 & $\mathrm{C}$ & -5.874 & 7.800 & 0.564 & $\mathrm{H}$ & -2.365 & 1.532 & 1.609 \\
\hline $\mathrm{N}$ & 2.908 & 3.952 & -2.915 & $\mathrm{H}$ & -6.462 & 8.398 & 1.263 & $\mathrm{H}$ & -5.833 & 3.174 & 1.214 \\
\hline $\mathrm{C}$ & 3.057 & 3.814 & -1.473 & $\mathrm{~N}$ & -6.496 & 6.604 & 0.169 & $\mathrm{H}$ & -4.147 & 3.637 & 1.572 \\
\hline $\mathrm{C}$ & 3.414 & 5.119 & -3.614 & $\mathrm{C}$ & -5.895 & 6.183 & -1.111 & $\mathrm{H}$ & -6.665 & 5.732 & -1.752 \\
\hline $\mathrm{H}$ & 3.983 & 5.744 & -2.913 & $\mathrm{C}$ & -6.769 & 5.593 & 1.191 & $\mathrm{H}$ & -5.106 & 5.424 & -0.951 \\
\hline $\mathrm{H}$ & 4.111 & 4.795 & -4.402 & $\mathrm{H}$ & -7.512 & 6.019 & 1.877 & $\mathrm{H}$ & -3.388 & 6.088 & -3.222 \\
\hline $\mathrm{C}$ & 1.341 & 2.931 & -5.370 & $\mathrm{H}$ & -7.232 & 4.738 & 0.692 & $\mathrm{H}$ & -4.150 & 5.913 & -4.827 \\
\hline $\mathrm{H}$ & 2.148 & 3.051 & -6.108 & $\mathrm{C}$ & -4.472 & 7.831 & 2.826 & $\mathrm{H}$ & -1.079 & 4.677 & -4.168 \\
\hline $\mathrm{H}$ & 0.549 & 2.339 & -5.844 & $\mathrm{H}$ & -3.601 & 8.449 & 3.053 & $\mathrm{H}$ & -1.134 & 3.742 & -5.688 \\
\hline $\mathrm{N}$ & 0.815 & 4.244 & -5.030 & $\mathrm{H}$ & -5.379 & 8.406 & 3.027 & $\mathrm{H}$ & 0.290 & 2.432 & -2.909 \\
\hline $\mathrm{C}$ & 1.621 & 5.431 & -5.330 & $\mathrm{~N}$ & -4.446 & 6.638 & 3.588 & $\mathrm{H}$ & 0.321 & 0.831 & -3.701 \\
\hline $\mathrm{H}$ & 2.264 & 5.238 & -6.199 & $\mathrm{C}$ & -5.473 & 5.627 & 3.352 & $\mathrm{H}$ & -0.008 & 3.680 & 4.769 \\
\hline $\mathrm{N}$ & 2.441 & 5.991 & -4.262 & $\mathrm{H}$ & -6.443 & 5.995 & 3.705 & $\mathrm{H}$ & -1.056 & 3.714 & 3.325 \\
\hline $\mathrm{C}$ & 1.541 & 6.748 & -3.398 & $\mathrm{~N}$ & -5.579 & 5.164 & 1.939 & $\mathrm{H}$ & -2.502 & 6.493 & 4.426 \\
\hline $\mathrm{N}$ & 0.541 & 7.278 & -4.314 & $\mathrm{C}$ & -5.194 & 3.739 & 1.904 & $\mathrm{H}$ & -2.627 & 5.842 & 2.773 \\
\hline $\mathrm{C}$ & 0.566 & 6.532 & -5.578 & $\mathrm{~N}$ & -5.381 & 3.286 & 3.273 & $\mathrm{H}$ & -2.704 & 8.788 & 1.066 \\
\hline $\mathrm{H}$ & 0.823 & 7.205 & -6.407 & $\mathrm{C}$ & -4.963 & 4.392 & 4.127 & $\mathrm{H}$ & -2.932 & 7.513 & -0.173 \\
\hline $\mathrm{N}$ & -0.628 & 5.780 & -5.941 & $\mathrm{H}$ & -5.437 & 4.267 & 5.111 & $\mathrm{H}$ & -1.118 & 7.833 & -2.140 \\
\hline $\mathrm{C}$ & -0.599 & 4.544 & -5.158 & $\mathrm{~N}$ & -3.535 & 4.657 & 4.289 & $\mathrm{H}$ & -0.891 & 9.583 & -1.853 \\
\hline C & -1.887 & 6.493 & -6.027 & $\mathrm{C}$ & -3.158 & 5.933 & 3.745 & $\mathrm{H}$ & 1.082 & 6.107 & -2.622 \\
\hline $\mathrm{H}$ & -1.756 & 7.278 & -6.787 & $\mathrm{C}$ & -2.788 & 4.048 & 5.392 & $\mathrm{H}$ & 2.087 & 7.558 & -2.891 \\
\hline $\mathrm{H}$ & -2.634 & 5.787 & -6.412 & $\mathrm{H}$ & -2.147 & 4.818 & 5.842 & $\mathrm{H}$ & 2.079 & 3.861 & -0.958 \\
\hline $\mathrm{C}$ & 0.209 & 8.684 & -4.340 & $\mathrm{H}$ & -3.508 & 3.730 & 6.158 & $\mathrm{H}$ & 3.700 & 4.606 & -1.060 \\
\hline $\mathrm{H}$ & 0.922 & 9.244 & -3.720 & $\mathrm{C}$ & -4.855 & 1.948 & 3.582 & $\mathrm{H}$ & -4.346 & 6.539 & 1.234 \\
\hline
\end{tabular}




\begin{tabular}{|c|c|c|c|c|c|c|c|c|c|c|c|}
\hline \multicolumn{12}{|c|}{ CB[7]A-H+_N4 } \\
\hline $\mathrm{C}$ & 0.048 & -0.062 & 0.031 & $\mathrm{H}$ & 0.359 & 8.991 & -5.147 & $\mathrm{H}$ & -5.079 & 1.694 & 4.480 \\
\hline $\mathrm{N}$ & 0.061 & -0.047 & 1.484 & $\mathrm{~N}$ & -1.099 & 8.950 & -3.696 & $\mathrm{H}$ & -5.305 & 1.229 & 2.788 \\
\hline $\mathrm{C}$ & 1.439 & -0.026 & 1.981 & $\mathrm{C}$ & -2.239 & 8.502 & -4.491 & $\mathrm{~N}$ & -3.365 & 1.818 & 3.286 \\
\hline $\mathrm{H}$ & 1.633 & -0.923 & 2.586 & $\mathrm{H}$ & -2.202 & 9.013 & -5.463 & $\mathrm{C}$ & -2.522 & 1.810 & 4.489 \\
\hline $\mathrm{N}$ & 1.872 & 1.145 & 2.733 & $\mathrm{~N}$ & -2.435 & 7.064 & -4.677 & $\mathrm{H}$ & -3.088 & 1.417 & 5.345 \\
\hline $\mathrm{C}$ & 2.160 & 2.189 & 1.752 & $\mathrm{C}$ & -3.686 & 6.632 & -4.086 & $\mathrm{~N}$ & -1.893 & 3.063 & 4.879 \\
\hline $\mathrm{N}$ & 2.660 & 1.457 & 0.601 & $\mathrm{~N}$ & -4.424 & 7.886 & -3.871 & $\mathrm{C}$ & -0.743 & 3.248 & 3.993 \\
\hline $\mathrm{C}$ & 2.289 & 0.042 & 0.692 & $\mathrm{C}$ & -3.451 & 8.919 & -3.630 & $\mathrm{~N}$ & -0.284 & 1.894 & 3.730 \\
\hline $\mathrm{H}$ & 3.193 & -0.582 & 0.729 & $\mathrm{H}$ & -3.869 & 9.898 & -3.900 & C & -1.325 & 0.923 & 4.086 \\
\hline $\mathrm{N}$ & 1.396 & -0.497 & -0.328 & $\mathrm{~N}$ & -2.875 & 8.999 & -2.259 & $\mathrm{H}$ & -0.971 & 0.272 & 4.898 \\
\hline $\mathrm{C}$ & 1.788 & -0.358 & -1.723 & $\mathrm{C}$ & -1.443 & 8.670 & -2.311 & $\mathrm{~N}$ & -1.876 & 0.086 & 3.028 \\
\hline $\mathrm{H}$ & 2.747 & -0.886 & -1.832 & $\mathrm{C}$ & -3.369 & 9.952 & -1.369 & C & -2.800 & 0.930 & 2.276 \\
\hline $\mathrm{H}$ & 1.044 & -0.905 & -2.318 & $\mathrm{H}$ & -2.575 & 10.457 & -0.808 & $\mathrm{C}$ & -0.954 & -0.736 & 2.255 \\
\hline C & 3.905 & 1.822 & -0.047 & $\mathrm{H}$ & -3.993 & 10.709 & -1.864 & $\mathrm{H}$ & -0.466 & -1.413 & 2.971 \\
\hline $\mathrm{H}$ & 4.432 & 2.560 & 0.571 & $\mathrm{C}$ & -5.619 & 7.865 & -3.066 & $\mathrm{H}$ & -1.564 & -1.354 & 1.584 \\
\hline $\mathrm{H}$ & 4.549 & 0.933 & -0.115 & $\mathrm{H}$ & -6.131 & 8.826 & -3.203 & C & 1.111 & 1.522 & 3.913 \\
\hline $\mathrm{N}$ & 3.825 & 2.378 & -1.392 & $\mathrm{H}$ & -6.276 & 7.082 & -3.462 & $\mathrm{H}$ & 1.645 & 2.358 & 4.385 \\
\hline $\mathrm{C}$ & 3.269 & 1.539 & -2.449 & $\mathrm{~N}$ & -5.463 & 7.641 & -1.622 & $\mathrm{H}$ & 1.163 & 0.668 & 4.605 \\
\hline $\mathrm{H}$ & 3.981 & 0.730 & -2.663 & $\mathrm{C}$ & -5.643 & 8.671 & -0.688 & $\mathrm{H}$ & 1.255 & 2.776 & 1.501 \\
\hline $\mathrm{N}$ & 1.926 & 0.987 & -2.252 & $\mathrm{H}$ & -6.297 & 9.482 & -1.028 & $\mathrm{H}$ & 2.918 & 2.885 & 2.143 \\
\hline $\mathrm{C}$ & 1.011 & 1.503 & -3.256 & $\mathrm{~N}$ & -4.305 & 9.396 & -0.252 & $\mathrm{H}$ & -0.700 & -0.771 & -0.355 \\
\hline $\mathrm{N}$ & 1.894 & 2.027 & -4.298 & $\mathrm{C}$ & -3.724 & 8.424 & 0.754 & $\mathrm{H}$ & -0.183 & 0.938 & -0.385 \\
\hline $\mathrm{C}$ & 3.086 & 2.525 & -3.624 & $\mathrm{~N}$ & -4.883 & 8.047 & 1.489 & $\mathrm{H}$ & -3.580 & 0.317 & 1.802 \\
\hline $\mathrm{H}$ & 3.922 & 2.517 & -4.336 & $\mathrm{C}$ & -6.074 & 7.965 & 0.640 & $\mathrm{H}$ & -2.283 & 1.502 & 1.484 \\
\hline $\mathrm{N}$ & 3.001 & 3.832 & -2.965 & $\mathrm{H}$ & -6.901 & 8.466 & 1.159 & $\mathrm{H}$ & -6.000 & 3.163 & 1.156 \\
\hline $\mathrm{C}$ & 3.191 & 3.686 & -1.530 & $\mathrm{~N}$ & -6.543 & 6.684 & 0.145 & $\mathrm{H}$ & -4.295 & 3.649 & 1.377 \\
\hline $\mathrm{C}$ & 3.471 & 5.004 & -3.671 & $\mathrm{C}$ & -5.729 & 6.337 & -1.012 & $\mathrm{H}$ & -6.292 & 5.700 & -1.706 \\
\hline $\mathrm{H}$ & 4.080 & 5.619 & -2.995 & $\mathrm{C}$ & -6.838 & 5.628 & 1.115 & $\mathrm{H}$ & -4.796 & 5.813 & -0.742 \\
\hline $\mathrm{H}$ & 4.118 & 4.694 & -4.504 & $\mathrm{H}$ & -7.617 & 6.032 & 1.778 & $\mathrm{H}$ & -3.526 & 6.088 & -3.135 \\
\hline $\mathrm{C}$ & 1.299 & 2.847 & -5.337 & $\mathrm{H}$ & -7.289 & 4.804 & 0.550 & $\mathrm{H}$ & -4.248 & 5.972 & -4.761 \\
\hline $\mathrm{H}$ & 2.070 & 2.979 & -6.112 & $\mathrm{C}$ & -4.925 & 7.941 & 2.954 & $\mathrm{H}$ & -1.094 & 4.577 & -4.056 \\
\hline $\mathrm{H}$ & 0.484 & 2.262 & -5.783 & $\mathrm{H}$ & -4.187 & 8.646 & 3.361 & $\mathrm{H}$ & -1.177 & 3.676 & -5.596 \\
\hline $\mathrm{N}$ & 0.786 & 4.159 & -4.958 & $\mathrm{H}$ & -5.920 & 8.288 & 3.262 & $\mathrm{H}$ & 0.353 & 2.292 & -2.844 \\
\hline $\mathrm{C}$ & 1.587 & 5.345 & -5.280 & $\mathrm{~N}$ & -4.700 & 6.665 & 3.576 & $\mathrm{H}$ & 0.371 & 0.705 & -3.662 \\
\hline $\mathrm{H}$ & 2.187 & 5.164 & -6.183 & $\mathrm{C}$ & -5.621 & 5.579 & 3.296 & $\mathrm{H}$ & 0.034 & 3.845 & 4.494 \\
\hline $\mathrm{N}$ & 2.460 & 5.887 & -4.246 & $\mathrm{H}$ & -6.614 & 5.837 & 3.689 & $\mathrm{H}$ & -1.026 & 3.771 & 3.059 \\
\hline $\mathrm{C}$ & 1.592 & 6.596 & -3.312 & $\mathrm{~N}$ & -5.721 & 5.141 & 1.893 & $\mathrm{H}$ & -2.687 & 6.663 & 4.232 \\
\hline $\mathrm{N}$ & 0.542 & 7.151 & -4.162 & $\mathrm{C}$ & -5.313 & 3.735 & 1.796 & $\mathrm{H}$ & -2.908 & 6.090 & 2.556 \\
\hline $\mathrm{C}$ & 0.530 & 6.454 & -5.459 & $\mathrm{~N}$ & -5.379 & 3.256 & 3.171 & $\mathrm{H}$ & -2.978 & 8.925 & 1.381 \\
\hline $\mathrm{H}$ & 0.769 & 7.159 & -6.268 & $\mathrm{C}$ & -4.976 & 4.375 & 4.008 & $\mathrm{H}$ & -3.237 & 7.636 & 0.165 \\
\hline $\mathrm{N}$ & -0.671 & 5.718 & -5.812 & $\mathrm{H}$ & -5.361 & 4.211 & 5.024 & $\mathrm{H}$ & -1.276 & 7.614 & -2.038 \\
\hline C & -0.632 & 4.464 & -5.056 & $\mathrm{~N}$ & -3.552 & 4.735 & 4.060 & $\mathrm{H}$ & -0.865 & 9.305 & -1.628 \\
\hline $\mathrm{C}$ & -1.922 & 6.435 & -5.897 & $\mathrm{C}$ & -3.352 & 6.086 & 3.572 & $\mathrm{H}$ & 1.169 & 5.918 & -2.548 \\
\hline $\mathrm{H}$ & -1.791 & 7.214 & -6.663 & $\mathrm{C}$ & -2.738 & 4.205 & 5.154 & $\mathrm{H}$ & 2.151 & 7.390 & -2.796 \\
\hline $\mathrm{H}$ & -2.678 & 5.733 & -6.269 & $\mathrm{H}$ & -2.090 & 5.007 & 5.530 & $\mathrm{H}$ & 2.228 & 3.732 & -0.986 \\
\hline $\mathrm{C}$ & 0.244 & 8.563 & -4.140 & $\mathrm{H}$ & -3.406 & 3.911 & 5.978 & $\mathrm{H}$ & 3.846 & 4.475 & -1.132 \\
\hline $\mathrm{H}$ & 0.952 & 9.082 & -3.483 & $\mathrm{C}$ & -4.796 & 1.944 & 3.447 & $\mathrm{H}$ & -4.609 & 10.213 & 0.290 \\
\hline
\end{tabular}




\begin{tabular}{|c|c|c|c|c|c|c|c|c|c|c|c|}
\hline \multicolumn{12}{|c|}{$\mathrm{CB}[8]$} \\
\hline $\mathrm{O}$ & -0.024 & -0.012 & -0.005 & C & -5.572 & -7.539 & -1.646 & $\mathrm{~N}$ & 5.255 & -8.724 & -0.912 \\
\hline C & -0.014 & -0.007 & 1.210 & $\mathrm{H}$ & -5.232 & -7.026 & -2.549 & C & 5.402 & -9.777 & 0.071 \\
\hline $\mathrm{N}$ & 1.117 & -0.030 & 2.027 & $\mathrm{H}$ & -6.580 & -7.955 & -1.810 & $\mathrm{H}$ & 6.428 & -10.176 & 0.041 \\
\hline C & 0.792 & 0.260 & 3.413 & C & -5.853 & -8.970 & 1.681 & $\mathrm{~N}$ & 5.042 & -9.450 & 1.434 \\
\hline $\mathrm{H}$ & 1.203 & 1.243 & 3.696 & $\mathrm{H}$ & -5.662 & -9.280 & 2.711 & C & 3.975 & -10.213 & 1.902 \\
\hline $\mathrm{N}$ & 1.172 & -0.731 & 4.391 & $\mathrm{H}$ & -6.848 & -9.319 & 1.364 & $\mathrm{O}$ & 3.572 & -10.259 & 3.047 \\
\hline C & 0.076 & -1.380 & 4.952 & $\mathrm{~N}$ & -4.845 & -9.604 & 0.857 & C & 6.233 & -7.675 & -1.114 \\
\hline $\mathrm{O}$ & 0.104 & -2.169 & 5.876 & C & -4.971 & -9.775 & -0.576 & $\mathrm{H}$ & 7.243 & -8.113 & -1.082 \\
\hline $\mathrm{N}$ & -1.064 & -0.915 & 4.297 & $\mathrm{H}$ & -5.981 & -10.142 & -0.820 & $\mathrm{H}$ & 6.044 & -7.250 & -2.103 \\
\hline C & -0.773 & 0.216 & 3.435 & $\mathrm{~N}$ & -4.654 & -8.628 & -1.399 & C & 5.918 & -8.748 & 2.346 \\
\hline $\mathrm{H}$ & -1.226 & 1.130 & 3.851 & C & -3.563 & -8.857 & -2.235 & $\mathrm{H}$ & 6.943 & -9.137 & 2.226 \\
\hline $\mathrm{N}$ & -1.127 & 0.081 & 2.041 & $\mathrm{O}$ & -3.179 & -8.132 & -3.131 & $\mathrm{H}$ & 5.562 & -8.952 & 3.359 \\
\hline C & -2.461 & 0.260 & 1.514 & $\mathrm{~N}$ & -3.027 & -10.095 & -1.889 & $\mathrm{~N}$ & 5.935 & -7.308 & 2.185 \\
\hline $\mathrm{H}$ & -2.363 & 0.419 & 0.437 & C & -3.840 & -10.802 & -0.923 & C & 6.725 & -6.634 & 1.170 \\
\hline $\mathrm{H}$ & -2.909 & 1.149 & 1.984 & $\mathrm{H}$ & -4.223 & -11.735 & -1.367 & $\mathrm{H}$ & 7.739 & -7.063 & 1.139 \\
\hline C & -2.378 & -1.162 & 4.857 & $\mathrm{~N}$ & -3.230 & -11.082 & 0.360 & $\mathrm{~N}$ & 6.171 & -6.587 & -0.163 \\
\hline $\mathrm{H}$ & -2.819 & -0.204 & 5.177 & C & -3.894 & -10.456 & 1.413 & C & 5.785 & -5.305 & -0.540 \\
\hline $\mathrm{H}$ & -2.239 & -1.813 & 5.724 & $\mathrm{O}$ & -3.709 & -10.653 & 2.597 & $\mathrm{O}$ & 5.399 & -4.965 & -1.641 \\
\hline $\mathrm{N}$ & -3.301 & -1.827 & 3.965 & C & -2.339 & -12.200 & 0.596 & $\mathrm{~N}$ & 5.977 & -4.471 & 0.561 \\
\hline C & -4.051 & -1.147 & 2.931 & $\mathrm{H}$ & -2.320 & -12.369 & 1.676 & C & 6.701 & -5.137 & 1.629 \\
\hline $\mathrm{H}$ & -4.484 & -0.217 & 3.334 & $\mathrm{H}$ & -2.738 & -13.091 & 0.086 & $\mathrm{H}$ & 7.706 & -4.698 & 1.730 \\
\hline $\mathrm{N}$ & -3.351 & -0.869 & 1.694 & C & -2.027 & -10.736 & -2.715 & $\mathrm{~N}$ & 6.054 & -5.189 & 2.919 \\
\hline C & -3.933 & -1.506 & 0.600 & $\mathrm{H}$ & -2.427 & -11.697 & -3.078 & C & 5.657 & -6.477 & 3.270 \\
\hline $\mathrm{O}$ & -3.668 & -1.312 & -0.570 & $\mathrm{H}$ & -1.834 & -10.073 & -3.563 & $\mathrm{O}$ & 5.199 & -6.820 & 4.342 \\
\hline $\mathrm{N}$ & -4.912 & -2.367 & 1.091 & $\mathrm{~N}$ & -0.755 & -10.968 & -2.060 & C & 5.957 & -3.031 & 0.399 \\
\hline C & -5.135 & -2.199 & 2.512 & C & -0.511 & -12.107 & -1.192 & $\mathrm{H}$ & 5.675 & -2.830 & -0.637 \\
\hline $\mathrm{H}$ & -6.166 & -1.854 & 2.691 & $\mathrm{H}$ & -0.914 & -13.023 & -1.653 & $\mathrm{H}$ & 6.965 & -2.631 & 0.595 \\
\hline $\mathrm{N}$ & -4.845 & -3.339 & 3.355 & $\mathrm{~N}$ & -0.972 & -11.999 & 0.172 & C & 6.034 & -4.100 & 3.870 \\
\hline C & -3.828 & -3.079 & 4.272 & C & 0.071 & -11.881 & 1.086 & $\mathrm{H}$ & 5.782 & -4.527 & 4.844 \\
\hline $\mathrm{O}$ & -3.495 & -3.793 & 5.197 & $\mathrm{O}$ & -0.032 & -11.880 & 2.296 & $\mathrm{H}$ & 7.037 & -3.647 & 3.909 \\
\hline C & -5.754 & -4.448 & 3.543 & $\mathrm{~N}$ & 1.259 & -11.823 & 0.357 & $\mathrm{~N}$ & 5.058 & -3.065 & 3.599 \\
\hline $\mathrm{H}$ & -6.779 & -4.054 & 3.647 & $\mathrm{C}$ & 1.048 & -12.124 & -1.049 & $\mathrm{C}$ & 5.259 & -2.008 & 2.630 \\
\hline $\mathrm{H}$ & -5.459 & -4.956 & 4.464 & $\mathrm{H}$ & 1.497 & -13.100 & -1.294 & $\mathrm{H}$ & 6.273 & -1.590 & 2.737 \\
\hline C & -5.853 & -3.016 & 0.202 & $\mathrm{~N}$ & 1.484 & -11.130 & -2.000 & $\mathrm{~N}$ & 5.008 & -2.339 & 1.244 \\
\hline $\mathrm{H}$ & -6.872 & -2.680 & 0.451 & C & 0.424 & -10.487 & -2.631 & $\mathrm{C}$ & 3.967 & -1.593 & 0.697 \\
\hline $\mathrm{H}$ & -5.597 & -2.703 & -0.814 & $\mathrm{O}$ & 0.508 & -9.690 & -3.544 & $\mathrm{O}$ & 3.651 & -1.551 & -0.476 \\
\hline $\mathrm{N}$ & -5.822 & -4.461 & 0.223 & $\mathrm{C}$ & 2.852 & -10.958 & -2.438 & $\mathrm{~N}$ & 3.390 & -0.861 & 1.732 \\
\hline C & -6.450 & -5.278 & 1.235 & $\mathrm{H}$ & 3.288 & -11.951 & -2.625 & $\mathrm{C}$ & 4.130 & -0.977 & 2.971 \\
\hline $\mathrm{H}$ & -7.470 & -4.911 & 1.433 & $\mathrm{H}$ & 2.823 & -10.384 & -3.367 & $\mathrm{H}$ & 4.519 & 0.011 & 3.267 \\
\hline $\mathrm{N}$ & -5.731 & -5.438 & 2.486 & $\mathrm{C}$ & 2.532 & -12.019 & 1.023 & $\mathrm{~N}$ & 3.440 & -1.587 & 4.088 \\
\hline C & -5.491 & -6.779 & 2.784 & $\mathrm{H}$ & 2.326 & -12.076 & 2.095 & $\mathrm{C}$ & 4.056 & -2.760 & 4.519 \\
\hline $\mathrm{O}$ & -5.095 & -7.221 & 3.844 & $\mathrm{H}$ & 2.977 & -12.967 & 0.678 & $\mathrm{O}$ & 3.799 & -3.377 & 5.533 \\
\hline $\mathrm{N}$ & -5.843 & -7.524 & 1.662 & $\mathrm{~N}$ & 3.489 & -10.953 & 0.826 & $\mathrm{C}$ & 2.433 & 0.189 & 1.463 \\
\hline C & -6.423 & -6.716 & 0.615 & $\mathrm{C}$ & 4.319 & -10.828 & -0.352 & $\mathrm{H}$ & 2.310 & 0.245 & 0.378 \\
\hline $\mathrm{H}$ & -7.424 & -7.098 & 0.358 & $\mathrm{H}$ & 4.747 & -11.809 & -0.614 & $\mathrm{H}$ & 2.834 & 1.143 & 1.842 \\
\hline $\mathrm{N}$ & -5.635 & -6.545 & -0.593 & $\mathrm{~N}$ & 3.706 & -10.232 & -1.521 & $\mathrm{C}$ & 2.503 & -0.879 & 4.936 \\
\hline C & -5.397 & -5.201 & -0.877 & C & 4.334 & -9.049 & -1.906 & $\mathrm{H}$ & 2.905 & 0.122 & 5.159 \\
\hline $\mathrm{O}$ & -4.948 & -4.753 & -1.914 & $\mathrm{O}$ & 4.145 & -8.438 & -2.939 & $\mathrm{H}$ & 2.411 & -1.456 & 5.860 \\
\hline
\end{tabular}




\begin{tabular}{|c|c|c|c|c|c|c|c|c|c|c|c|}
\hline \multicolumn{12}{|c|}{ CB[8]-H+_N2 } \\
\hline $\mathrm{O}$ & -0.182 & -0.034 & -0.062 & $\mathrm{H}$ & -5.540 & -6.826 & -2.379 & $\mathrm{C}$ & 5.068 & -9.833 & 0.109 \\
\hline $\mathrm{C}$ & -0.096 & -0.082 & 1.138 & $\mathrm{H}$ & -6.920 & -7.746 & -1.693 & $\mathrm{H}$ & 6.068 & -10.295 & 0.126 \\
\hline $\mathrm{N}$ & 1.069 & -0.232 & 1.908 & $\mathrm{C}$ & -6.307 & -8.880 & 1.771 & $\mathrm{~N}$ & 4.695 & -9.411 & 1.444 \\
\hline $\mathrm{C}$ & 0.806 & 0.116 & 3.289 & $\mathrm{H}$ & -6.150 & -9.227 & 2.795 & $\mathrm{C}$ & 3.593 & -10.115 & 1.934 \\
\hline $\mathrm{H}$ & 1.145 & 1.137 & 3.519 & $\mathrm{H}$ & -7.302 & -9.189 & 1.419 & $\mathrm{O}$ & 3.170 & -10.078 & 3.073 \\
\hline $\mathrm{N}$ & 1.317 & -0.781 & 4.318 & $\mathrm{~N}$ & -5.293 & -9.505 & 0.955 & $\mathrm{C}$ & 6.040 & -7.841 & -1.157 \\
\hline $\mathrm{C}$ & 0.410 & -1.620 & 4.860 & $\mathrm{C}$ & -5.375 & -9.632 & -0.484 & $\mathrm{H}$ & 7.025 & -8.328 & -1.102 \\
\hline $\mathrm{O}$ & 0.449 & -2.392 & 5.770 & $\mathrm{H}$ & -6.379 & -9.979 & -0.776 & $\mathrm{H}$ & 5.880 & -7.441 & -2.161 \\
\hline $\mathrm{N}$ & -0.900 & -1.410 & 4.043 & $\mathrm{~N}$ & -5.012 & -8.459 & -1.253 & $\mathrm{C}$ & 5.604 & -8.746 & 2.348 \\
\hline $\mathrm{C}$ & -0.729 & -0.027 & 3.377 & $\mathrm{C}$ & -3.911 & -8.685 & -2.081 & $\mathrm{H}$ & 6.600 & -9.210 & 2.266 \\
\hline $\mathrm{H}$ & -1.203 & 0.688 & 4.054 & $\mathrm{O}$ & -3.493 & -7.928 & -2.935 & $\mathrm{H}$ & 5.217 & -8.883 & 3.360 \\
\hline $\mathrm{N}$ & -1.174 & 0.037 & 2.048 & $\mathrm{~N}$ & -3.418 & -9.950 & -1.781 & $\mathrm{~N}$ & 5.732 & -7.314 & 2.133 \\
\hline $\mathrm{C}$ & -2.565 & 0.228 & 1.641 & $\mathrm{C}$ & -4.242 & -10.658 & -0.825 & $\mathrm{C}$ & 6.580 & -6.743 & 1.096 \\
\hline $\mathrm{H}$ & -2.554 & 0.413 & 0.564 & $\mathrm{H}$ & -4.621 & -11.590 & -1.274 & $\mathrm{H}$ & 7.561 & -7.242 & 1.094 \\
\hline $\mathrm{H}$ & -2.955 & 1.111 & 2.167 & $\mathrm{~N}$ & -3.639 & -10.941 & 0.463 & $\mathrm{~N}$ & 6.038 & -6.714 & -0.242 \\
\hline $\mathrm{C}$ & -2.183 & -1.624 & 4.860 & $\mathrm{C}$ & -4.328 & -10.343 & 1.514 & $\mathrm{C}$ & 5.678 & -5.437 & -0.649 \\
\hline $\mathrm{H}$ & -2.373 & -0.672 & 5.368 & $\mathrm{O}$ & -4.155 & -10.541 & 2.700 & $\mathrm{O}$ & 5.275 & -5.109 & -1.746 \\
\hline $\mathrm{H}$ & -1.958 & -2.412 & 5.585 & $\mathrm{C}$ & -2.755 & -12.068 & 0.699 & $\mathrm{~N}$ & 5.916 & -4.574 & 0.429 \\
\hline $\mathrm{N}$ & -3.241 & -2.060 & 4.034 & $\mathrm{H}$ & -2.738 & -12.237 & 1.779 & $\mathrm{C}$ & 6.659 & -5.231 & 1.492 \\
\hline $\mathrm{C}$ & -4.034 & -1.219 & 3.144 & $\mathrm{H}$ & -3.162 & -12.955 & 0.190 & $\mathrm{H}$ & 7.689 & -4.844 & 1.534 \\
\hline $\mathrm{H}$ & -4.350 & -0.303 & 3.663 & $\mathrm{C}$ & -2.417 & -10.587 & -2.610 & $\mathrm{~N}$ & 6.059 & -5.196 & 2.803 \\
\hline $\mathrm{N}$ & -3.416 & -0.913 & 1.874 & $\mathrm{H}$ & -2.825 & -11.538 & -2.988 & $\mathrm{C}$ & 5.527 & -6.430 & 3.186 \\
\hline $\mathrm{C}$ & -4.118 & -1.491 & 0.793 & $\mathrm{H}$ & -2.212 & -9.915 & -3.448 & $\mathrm{O}$ & 5.020 & -6.678 & 4.262 \\
\hline $\mathrm{O}$ & -3.902 & -1.259 & -0.375 & $\mathrm{~N}$ & -1.151 & -10.838 & -1.950 & $\mathrm{C}$ & 5.945 & -3.148 & 0.214 \\
\hline $\mathrm{N}$ & -5.097 & -2.312 & 1.326 & $\mathrm{C}$ & -0.928 & -11.990 & -1.090 & $\mathrm{H}$ & 5.643 & -2.974 & -0.821 \\
\hline $\mathrm{C}$ & -5.234 & -2.158 & 2.761 & $\mathrm{H}$ & -1.347 & -12.895 & -1.556 & $\mathrm{H}$ & 6.965 & -2.764 & 0.373 \\
\hline $\mathrm{H}$ & -6.215 & -1.723 & 3.003 & $\mathrm{~N}$ & -1.389 & -11.876 & 0.273 & $\mathrm{C}$ & 6.114 & -4.081 & 3.708 \\
\hline $\mathrm{N}$ & -5.020 & -3.347 & 3.566 & $\mathrm{C}$ & -0.346 & -11.738 & 1.184 & $\mathrm{H}$ & 5.897 & -4.460 & 4.710 \\
\hline $\mathrm{C}$ & -3.875 & -3.300 & 4.319 & $\mathrm{O}$ & -0.451 & -11.701 & 2.394 & $\mathrm{H}$ & 7.123 & -3.646 & 3.684 \\
\hline $\mathrm{O}$ & -3.458 & -4.107 & 5.120 & $\mathrm{~N}$ & 0.843 & -11.704 & 0.455 & $\mathrm{~N}$ & 5.145 & -3.018 & 3.446 \\
\hline $\mathrm{C}$ & -6.007 & -4.412 & 3.733 & $\mathrm{C}$ & 0.629 & -12.032 & -0.946 & $\mathrm{C}$ & 5.333 & -1.998 & 2.423 \\
\hline $\mathrm{H}$ & -6.990 & -3.937 & 3.866 & $\mathrm{H}$ & 1.060 & -13.020 & -1.171 & $\mathrm{H}$ & 6.352 & -1.590 & 2.488 \\
\hline $\mathrm{H}$ & -5.737 & -4.962 & 4.638 & $\mathrm{~N}$ & 1.084 & -11.061 & -1.911 & $\mathrm{~N}$ & 5.041 & -2.386 & 1.062 \\
\hline C & -6.139 & -2.881 & 0.471 & $\mathrm{C}$ & 0.037 & -10.383 & -2.526 & $\mathrm{C}$ & 3.909 & -1.773 & 0.555 \\
\hline $\mathrm{H}$ & -7.113 & -2.494 & 0.803 & $\mathrm{O}$ & 0.135 & -9.576 & -3.429 & $\mathrm{O}$ & 3.475 & -1.844 & -0.575 \\
\hline $\mathrm{H}$ & -5.928 & -2.535 & -0.544 & $\mathrm{C}$ & 2.450 & -10.934 & -2.365 & $\mathrm{~N}$ & 3.360 & -0.989 & 1.587 \\
\hline $\mathrm{N}$ & -6.186 & -4.316 & 0.436 & $\mathrm{H}$ & 2.855 & -11.941 & -2.548 & $\mathrm{C}$ & 4.224 & -0.938 & 2.749 \\
\hline $\mathrm{C}$ & -6.808 & -5.153 & 1.431 & $\mathrm{H}$ & 2.431 & -10.368 & -3.300 & $\mathrm{H}$ & 4.622 & 0.078 & 2.892 \\
\hline $\mathrm{H}$ & -7.818 & -4.784 & 1.666 & $\mathrm{C}$ & 2.109 & -11.924 & 1.127 & $\mathrm{~N}$ & 3.653 & -1.432 & 3.984 \\
\hline $\mathrm{N}$ & -6.052 & -5.364 & 2.655 & $\mathrm{H}$ & 1.902 & -11.941 & 2.200 & $\mathrm{C}$ & 4.226 & -2.646 & 4.406 \\
\hline $\mathrm{C}$ & -5.854 & -6.728 & 2.921 & $\mathrm{H}$ & 2.523 & -12.896 & 0.813 & $\mathrm{O}$ & 3.964 & -3.207 & 5.450 \\
\hline $\mathrm{O}$ & -5.440 & -7.191 & 3.964 & $\mathrm{~N}$ & 3.105 & -10.900 & 0.896 & $\mathrm{C}$ & 2.376 & 0.008 & 1.279 \\
\hline $\mathrm{N}$ & -6.268 & -7.428 & 1.800 & $\mathrm{C}$ & 3.932 & -10.835 & -0.290 & $\mathrm{H}$ & 2.206 & -0.008 & 0.200 \\
\hline $\mathrm{C}$ & -6.805 & -6.571 & 0.767 & $\mathrm{H}$ & 4.308 & -11.839 & -0.540 & $\mathrm{H}$ & 2.737 & 1.004 & 1.583 \\
\hline $\mathrm{H}$ & -7.809 & -6.916 & 0.479 & $\mathrm{~N}$ & 3.335 & -10.224 & -1.462 & $\mathrm{C}$ & 2.723 & -0.737 & 4.806 \\
\hline $\mathrm{N}$ & -5.983 & -6.382 & -0.418 & $\mathrm{C}$ & 4.041 & -9.103 & -1.891 & $\mathrm{H}$ & 2.987 & 0.324 & 4.893 \\
\hline $\mathrm{C}$ & -5.714 & -5.042 & -0.663 & $\mathrm{O}$ & 3.879 & -8.502 & -2.934 & $\mathrm{H}$ & 2.731 & -1.210 & 5.791 \\
\hline $\mathrm{O}$ & -5.207 & -4.565 & -1.657 & $\mathrm{~N}$ & 5.006 & -8.823 & -0.924 & $\mathrm{H}$ & -0.904 & -2.127 & 3.304 \\
\hline $\mathrm{C}$ & -5.908 & -7.356 & -1.497 & & & & & & & & \\
\hline
\end{tabular}




\section{CB[8]-H+_N4}

\begin{tabular}{|c|c|c|c|c|c|c|c|c|c|c|c|}
\hline $\mathrm{O}$ & 0.253 & -0.039 & -0.058 & $\mathrm{H}$ & -5.962 & -7.282 & -2.270 & C & 5.199 & -9.775 & -0.386 \\
\hline $\mathrm{C}$ & 0.145 & -0.083 & 1.140 & $\mathrm{H}$ & -7.147 & -8.139 & -1.230 & $\mathrm{H}$ & 6.199 & -10.146 & -0.658 \\
\hline $\mathrm{N}$ & 1.208 & 0.008 & 2.069 & $\mathrm{C}$ & -5.798 & -8.591 & 2.242 & $\mathrm{~N}$ & 5.091 & -9.646 & 1.051 \\
\hline C & 0.738 & -0.044 & 3.390 & $\mathrm{H}$ & -5.433 & -8.739 & 3.262 & $\mathrm{C}$ & 4.096 & -10.463 & 1.589 \\
\hline $\mathrm{H}$ & 1.220 & 0.658 & 4.076 & $\mathrm{H}$ & -6.804 & -9.029 & 2.141 & $\mathrm{O}$ & 3.895 & -10.658 & 2.772 \\
\hline $\mathrm{N}$ & 0.858 & -1.430 & 4.060 & $\mathrm{~N}$ & -4.890 & -9.280 & 1.355 & $\mathrm{C}$ & 5.809 & -7.513 & -1.389 \\
\hline C & -0.472 & -1.602 & 4.853 & $\mathrm{C}$ & -5.252 & -9.693 & 0.013 & $\mathrm{H}$ & 6.813 & -7.929 & -1.567 \\
\hline $\mathrm{O}$ & -0.551 & -2.373 & 5.762 & $\mathrm{H}$ & -6.263 & -10.128 & 0.014 & $\mathrm{H}$ & 5.470 & -6.973 & -2.276 \\
\hline $\mathrm{N}$ & -1.346 & -0.738 & 4.293 & $\mathrm{~N}$ & -5.146 & -8.685 & -1.018 & $\mathrm{C}$ & 6.103 & -9.048 & 1.887 \\
\hline C & -0.791 & 0.143 & 3.274 & $\mathrm{C}$ & -4.171 & -8.991 & -1.968 & $\mathrm{H}$ & 7.097 & -9.384 & 1.556 \\
\hline $\mathrm{H}$ & -1.105 & 1.173 & 3.497 & $\mathrm{O}$ & -3.975 & -8.395 & -3.009 & $\mathrm{H}$ & 5.916 & -9.390 & 2.908 \\
\hline $\mathrm{N}$ & -1.038 & -0.200 & 1.889 & $\mathrm{~N}$ & -3.502 & -10.129 & -1.526 & $\mathrm{~N}$ & 6.102 & -7.596 & 1.916 \\
\hline C & -2.326 & 0.075 & 1.236 & $\mathrm{C}$ & -4.136 & -10.725 & -0.365 & $\mathrm{C}$ & 6.682 & -6.753 & 0.894 \\
\hline $\mathrm{H}$ & -2.136 & 0.053 & 0.160 & $\mathrm{H}$ & -4.534 & -11.719 & -0.623 & $\mathrm{H}$ & 7.682 & -7.125 & 0.625 \\
\hline $\mathrm{H}$ & -2.667 & 1.079 & 1.532 & $\mathrm{~N}$ & -3.332 & -10.812 & 0.835 & $\mathrm{~N}$ & 5.888 & -6.543 & -0.307 \\
\hline C & -2.759 & -0.655 & 4.754 & $\mathrm{C}$ & -3.818 & -10.014 & 1.865 & $\mathrm{C}$ & 5.661 & -5.195 & -0.556 \\
\hline $\mathrm{H}$ & -2.996 & 0.413 & 4.834 & $\mathrm{O}$ & -3.414 & -9.988 & 3.011 & $\mathrm{O}$ & 5.185 & -4.705 & -1.560 \\
\hline $\mathrm{H}$ & -2.800 & -1.124 & 5.740 & $\mathrm{C}$ & -2.370 & -11.864 & 1.085 & $\mathrm{~N}$ & 6.130 & -4.483 & 0.552 \\
\hline $\mathrm{N}$ & -3.692 & -1.326 & 3.917 & $\mathrm{H}$ & -2.184 & -11.886 & 2.161 & $\mathrm{C}$ & 6.709 & -5.336 & 1.559 \\
\hline C & -4.227 & -0.820 & 2.670 & $\mathrm{H}$ & -2.806 & -12.824 & 0.764 & $\mathrm{H}$ & 7.724 & -4.994 & 1.814 \\
\hline $\mathrm{H}$ & -4.601 & 0.206 & 2.804 & $\mathrm{C}$ & -2.620 & -10.864 & -2.414 & $\mathrm{~N}$ & 5.923 & -5.526 & 2.768 \\
\hline $\mathrm{N}$ & -3.342 & -0.896 & 1.525 & $\mathrm{H}$ & -3.050 & -11.859 & -2.606 & $\mathrm{C}$ & 5.686 & -6.885 & 3.029 \\
\hline C & -3.892 & -1.667 & 0.483 & $\mathrm{H}$ & -2.567 & -10.298 & -3.347 & $\mathrm{O}$ & 5.239 & -7.337 & 4.063 \\
\hline $\mathrm{O}$ & -3.437 & -1.750 & -0.638 & $\mathrm{~N}$ & -1.267 & -11.030 & -1.934 & $\mathrm{C}$ & 6.123 & -3.047 & 0.587 \\
\hline $\mathrm{N}$ & -5.048 & -2.250 & 0.969 & $\mathrm{C}$ & -0.857 & -12.014 & -0.961 & $\mathrm{H}$ & 5.942 & -2.695 & -0.431 \\
\hline $\mathrm{C}$ & -5.356 & -1.852 & 2.324 & $\mathrm{H}$ & -1.312 & -12.989 & -1.196 & $\mathrm{H}$ & 7.099 & -2.687 & 0.940 \\
\hline $\mathrm{H}$ & -6.365 & -1.419 & 2.370 & $\mathrm{~N}$ & -1.087 & -11.680 & 0.436 & $\mathrm{C}$ & 5.883 & -4.574 & 3.845 \\
\hline $\mathrm{N}$ & -5.212 & -2.876 & 3.351 & $\mathrm{C}$ & 0.088 & -11.749 & 1.186 & $\mathrm{H}$ & 5.581 & -5.117 & 4.744 \\
\hline C & -4.301 & -2.526 & 4.327 & $\mathrm{O}$ & 0.173 & -11.716 & 2.398 & $\mathrm{H}$ & 6.877 & -4.126 & 3.997 \\
\hline $\mathrm{O}$ & -4.071 & -3.093 & 5.376 & $\mathrm{~N}$ & 1.143 & -11.915 & 0.293 & $\mathrm{~N}$ & 4.930 & -3.482 & 3.660 \\
\hline C & -6.210 & -3.916 & 3.596 & $\mathrm{C}$ & 0.703 & -12.016 & -1.078 & $\mathrm{C}$ & 5.192 & -2.300 & 2.860 \\
\hline $\mathrm{H}$ & -7.209 & -3.457 & 3.556 & $\mathrm{H}$ & 1.104 & -12.933 & -1.537 & $\mathrm{H}$ & 6.179 & -1.892 & 3.121 \\
\hline $\mathrm{H}$ & -6.019 & -4.300 & 4.600 & $\mathrm{~N}$ & 0.973 & -10.871 & -1.933 & $\mathrm{~N}$ & 5.079 & -2.450 & 1.422 \\
\hline C & -5.957 & -2.986 & 0.105 & $\mathrm{C}$ & -0.190 & -10.381 & -2.529 & $\mathrm{C}$ & 4.132 & -1.605 & 0.870 \\
\hline $\mathrm{H}$ & -6.969 & -2.575 & 0.245 & $\mathrm{O}$ & -0.250 & -9.572 & -3.433 & $\mathrm{O}$ & 3.945 & -1.368 & -0.302 \\
\hline $\mathrm{H}$ & -5.631 & -2.822 & -0.925 & $\mathrm{C}$ & 2.257 & -10.653 & -2.569 & $\mathrm{~N}$ & 3.424 & -1.009 & 1.938 \\
\hline $\mathrm{N}$ & -5.970 & -4.413 & 0.319 & $\mathrm{H}$ & 2.647 & -11.615 & -2.939 & $\mathrm{C}$ & 4.012 & -1.328 & 3.219 \\
\hline $\mathrm{C}$ & -6.746 & -5.050 & 1.370 & $\mathrm{H}$ & 2.087 & -9.977 & -3.410 & $\mathrm{H}$ & 4.343 & -0.419 & 3.741 \\
\hline $\mathrm{H}$ & -7.766 & -4.637 & 1.396 & $\mathrm{C}$ & 2.496 & -12.147 & 0.742 & $\mathrm{~N}$ & 3.180 & -2.145 & 4.097 \\
\hline $\mathrm{N}$ & -6.167 & -5.031 & 2.691 & $\mathrm{H}$ & 2.455 & -12.318 & 1.820 & $\mathrm{C}$ & 3.773 & -3.402 & 4.393 \\
\hline C & -5.674 & -6.278 & 3.082 & $\mathrm{H}$ & 2.886 & -13.044 & 0.237 & $\mathrm{O}$ & 3.320 & -4.196 & 5.187 \\
\hline $\mathrm{O}$ & -5.192 & -6.539 & 4.166 & $\mathrm{~N}$ & 3.415 & -11.045 & 0.525 & $\mathrm{C}$ & 2.611 & 0.157 & 1.688 \\
\hline $\mathrm{N}$ & -5.885 & -7.157 & 2.026 & $\mathrm{C}$ & 4.048 & -10.773 & -0.752 & $\mathrm{H}$ & 2.625 & 0.340 & 0.610 \\
\hline C & -6.700 & -6.564 & 0.975 & $\mathrm{H}$ & 4.413 & -11.712 & -1.196 & $\mathrm{H}$ & 3.018 & 1.028 & 2.220 \\
\hline $\mathrm{H}$ & -7.692 & -7.039 & 0.956 & $\mathrm{~N}$ & 3.259 & -10.043 & -1.721 & $\mathrm{C}$ & 2.118 & -1.679 & 4.901 \\
\hline $\mathrm{N}$ & -6.134 & -6.550 & -0.354 & $\mathrm{C}$ & 3.789 & -8.791 & -2.010 & $\mathrm{H}$ & 2.325 & -0.731 & 5.411 \\
\hline C & -5.736 & -5.283 & -0.755 & $\mathrm{O}$ & 3.406 & -8.023 & -2.870 & $\mathrm{H}$ & 1.857 & -2.458 & 5.623 \\
\hline $\mathrm{O}$ & -5.305 & -4.966 & -1.845 & $\mathrm{~N}$ & 4.880 & -8.594 & -1.162 & $\mathrm{H}$ & 0.855 & -2.148 & 3.321 \\
\hline C & -6.149 & -7.676 & -1.268 & & & & & & & & \\
\hline
\end{tabular}




\begin{tabular}{|c|c|c|c|c|c|c|c|c|c|c|c|}
\hline \multicolumn{12}{|c|}{ CB[8]A } \\
\hline $\mathrm{C}$ & 0.035 & -0.031 & -0.006 & $\mathrm{C}$ & -2.263 & 9.262 & -5.687 & $\mathrm{H}$ & -5.328 & 0.948 & 3.154 \\
\hline $\mathrm{N}$ & 0.028 & -0.018 & 1.450 & $\mathrm{H}$ & -2.485 & 10.192 & -6.231 & $\mathrm{H}$ & -4.978 & 1.192 & 4.873 \\
\hline $\mathrm{C}$ & 1.407 & -0.014 & 1.955 & $\mathrm{~N}$ & -1.934 & 9.566 & -4.288 & $\mathrm{C}$ & -2.728 & 3.876 & 5.595 \\
\hline $\mathrm{H}$ & 1.590 & -0.919 & 2.552 & $\mathrm{C}$ & -0.569 & 9.146 & -4.001 & $\mathrm{H}$ & -2.082 & 4.696 & 5.933 \\
\hline $\mathrm{N}$ & 1.852 & 1.146 & 2.715 & $\mathrm{C}$ & -2.470 & 10.791 & -3.715 & $\mathrm{H}$ & -3.264 & 3.495 & 6.478 \\
\hline $\mathrm{C}$ & 2.106 & 2.199 & 1.732 & $\mathrm{H}$ & -1.688 & 11.280 & -3.120 & $\mathrm{~N}$ & -1.853 & 2.800 & 5.156 \\
\hline $\mathrm{N}$ & 2.625 & 1.479 & 0.577 & $\mathrm{H}$ & -2.743 & 11.482 & -4.529 & $\mathrm{C}$ & -2.463 & 1.558 & 4.706 \\
\hline $\mathrm{C}$ & 2.264 & 0.058 & 0.673 & $\mathrm{C}$ & -4.652 & 8.591 & -5.414 & $\mathrm{H}$ & -2.947 & 1.070 & 5.564 \\
\hline $\mathrm{H}$ & 3.174 & -0.557 & 0.721 & $\mathrm{H}$ & -4.987 & 9.515 & -5.910 & $\mathrm{~N}$ & -3.395 & 1.619 & 3.572 \\
\hline $\mathrm{N}$ & 1.381 & -0.492 & -0.345 & $\mathrm{H}$ & -5.312 & 7.781 & -5.750 & $\mathrm{C}$ & -2.861 & 0.850 & 2.454 \\
\hline $\mathrm{C}$ & 1.802 & -0.408 & -1.736 & $\mathrm{~N}$ & -4.783 & 8.746 & -3.975 & $\mathrm{~N}$ & -1.857 & -0.017 & 3.073 \\
\hline $\mathrm{H}$ & 1.033 & -0.915 & -2.333 & $\mathrm{C}$ & -4.855 & 10.109 & -3.433 & $\mathrm{C}$ & -1.263 & 0.764 & 4.148 \\
\hline $\mathrm{H}$ & 2.724 & -1.005 & -1.815 & $\mathrm{H}$ & -5.246 & 10.796 & -4.197 & $\mathrm{H}$ & -0.817 & 0.076 & 4.880 \\
\hline $\mathrm{C}$ & 3.916 & 1.817 & 0.003 & $\mathrm{~N}$ & -3.644 & 10.682 & -2.864 & $\mathrm{~N}$ & -0.295 & 1.809 & 3.787 \\
\hline $\mathrm{H}$ & 4.575 & 0.935 & 0.051 & $\mathrm{C}$ & -3.484 & 10.062 & -1.548 & $\mathrm{C}$ & -0.813 & 3.115 & 4.176 \\
\hline $\mathrm{H}$ & 4.382 & 2.607 & 0.607 & $\mathrm{~N}$ & -4.852 & 9.894 & -1.073 & $\mathrm{C}$ & -0.969 & -0.766 & 2.198 \\
\hline $\mathrm{N}$ & 3.944 & 2.269 & -1.379 & $\mathrm{C}$ & -5.783 & 9.965 & -2.207 & $\mathrm{H}$ & -1.604 & -1.320 & 1.496 \\
\hline $\mathrm{C}$ & 3.432 & 1.372 & -2.405 & $\mathrm{H}$ & -6.468 & 10.815 & -2.076 & $\mathrm{H}$ & -0.461 & -1.506 & 2.837 \\
\hline $\mathrm{H}$ & 4.105 & 0.506 & -2.486 & $\mathrm{~N}$ & -6.564 & 8.778 & -2.523 & $\mathrm{C}$ & 1.119 & 1.500 & 3.921 \\
\hline $\mathrm{N}$ & 2.041 & 0.914 & -2.290 & $\mathrm{C}$ & -5.649 & 7.863 & -3.205 & $\mathrm{H}$ & 1.240 & 0.652 & 4.614 \\
\hline $\mathrm{C}$ & 1.263 & 1.404 & -3.420 & $\mathrm{C}$ & -7.431 & 8.233 & -1.489 & $\mathrm{H}$ & 1.634 & 2.361 & 4.366 \\
\hline $\mathrm{N}$ & 2.276 & 1.754 & -4.416 & $\mathrm{H}$ & -8.183 & 9.010 & -1.277 & $\mathrm{H}$ & -5.069 & 7.253 & -2.488 \\
\hline C & 3.419 & 2.258 & -3.670 & $\mathrm{H}$ & -7.959 & 7.379 & -1.933 & $\mathrm{H}$ & -6.207 & 7.179 & -3.861 \\
\hline $\mathrm{H}$ & 4.322 & 2.147 & -4.289 & $\mathrm{C}$ & -5.277 & 10.466 & 0.193 & $\mathrm{H}$ & -2.811 & 6.721 & -4.608 \\
\hline $\mathrm{N}$ & 3.346 & 3.624 & -3.136 & $\mathrm{H}$ & -4.443 & 11.028 & 0.632 & $\mathrm{H}$ & -3.285 & 6.212 & -6.252 \\
\hline C & 3.387 & 3.588 & -1.681 & $\mathrm{H}$ & -6.094 & 11.181 & 0.010 & $\mathrm{H}$ & -0.441 & 4.672 & -4.874 \\
\hline C & 4.012 & 4.682 & -3.876 & $\mathrm{~N}$ & -5.756 & 9.554 & 1.220 & $\mathrm{H}$ & -0.478 & 3.504 & -6.224 \\
\hline $\mathrm{H}$ & 4.772 & 4.238 & -4.538 & $\mathrm{C}$ & -6.907 & 8.716 & 0.913 & $\mathrm{H}$ & 0.646 & 2.276 & -3.137 \\
\hline $\mathrm{H}$ & 4.537 & 5.339 & -3.171 & $\mathrm{H}$ & -7.795 & 9.358 & 0.816 & $\mathrm{H}$ & 0.593 & 0.625 & -3.812 \\
\hline $\mathrm{C}$ & 1.849 & 2.487 & -5.598 & $\mathrm{~N}$ & -6.815 & 7.815 & -0.242 & $\mathrm{H}$ & -0.720 & -0.726 & -0.404 \\
\hline $\mathrm{H}$ & 2.688 & 2.438 & -6.310 & $\mathrm{C}$ & -6.887 & 6.430 & 0.204 & $\mathrm{H}$ & -0.171 & 0.973 & -0.420 \\
\hline $\mathrm{H}$ & 1.014 & 1.926 & -6.038 & $\mathrm{~N}$ & -7.486 & 6.524 & 1.536 & $\mathrm{H}$ & -3.644 & 0.247 & 1.972 \\
\hline $\mathrm{N}$ & 1.452 & 3.874 & -5.426 & $\mathrm{C}$ & -6.974 & 7.755 & 2.121 & $\mathrm{H}$ & -2.414 & 1.509 & 1.688 \\
\hline $\mathrm{C}$ & 2.423 & 4.916 & -5.788 & $\mathrm{H}$ & -7.668 & 8.089 & 2.906 & $\mathrm{H}$ & -6.464 & 2.963 & 1.946 \\
\hline $\mathrm{H}$ & 3.121 & 4.530 & -6.545 & $\mathrm{~N}$ & -5.600 & 7.752 & 2.638 & $\mathrm{H}$ & -4.793 & 3.590 & 1.959 \\
\hline $\mathrm{N}$ & 3.190 & 5.537 & -4.718 & $\mathrm{C}$ & -4.780 & 8.678 & 1.870 & $\mathrm{H}$ & -7.524 & 5.829 & -0.461 \\
\hline $\mathrm{C}$ & 2.278 & 6.474 & -4.061 & $\mathrm{C}$ & -7.502 & 5.326 & 2.362 & $\mathrm{H}$ & -5.886 & 5.963 & 0.236 \\
\hline $\mathrm{N}$ & 1.452 & 6.979 & -5.150 & $\mathrm{H}$ & -8.183 & 5.539 & 3.201 & $\mathrm{H}$ & 1.666 & 5.974 & -3.287 \\
\hline $\mathrm{C}$ & 1.540 & 6.072 & -6.302 & $\mathrm{H}$ & -7.962 & 4.531 & 1.761 & $\mathrm{H}$ & 2.843 & 7.285 & -3.579 \\
\hline $\mathrm{H}$ & 1.973 & 6.602 & -7.163 & $\mathrm{C}$ & -5.405 & 7.589 & 4.068 & $\mathrm{H}$ & -0.548 & 8.186 & -3.452 \\
\hline $\mathrm{N}$ & 0.326 & 5.394 & -6.731 & $\mathrm{H}$ & -6.341 & 7.844 & 4.590 & $\mathrm{H}$ & -0.036 & 9.896 & -3.399 \\
\hline $\mathrm{C}$ & 0.106 & 4.316 & -5.767 & $\mathrm{H}$ & -4.637 & 8.295 & 4.409 & $\mathrm{H}$ & -2.907 & 10.719 & -0.882 \\
\hline C & -0.816 & 6.209 & -7.117 & $\mathrm{~N}$ & -5.015 & 6.273 & 4.552 & $\mathrm{H}$ & -2.958 & 9.091 & -1.613 \\
\hline $\mathrm{H}$ & -1.602 & 5.520 & -7.452 & $\mathrm{C}$ & -5.908 & 5.155 & 4.287 & $\mathrm{H}$ & -4.117 & 9.262 & 2.524 \\
\hline $\mathrm{H}$ & -0.494 & 6.791 & -7.995 & $\mathrm{H}$ & -6.833 & 5.298 & 4.864 & $\mathrm{H}$ & -4.151 & 8.146 & 1.132 \\
\hline $\mathrm{C}$ & 1.359 & 8.405 & -5.412 & $\mathrm{~N}$ & -6.233 & 4.850 & 2.887 & $\mathrm{H}$ & -2.918 & 6.362 & 4.812 \\
\hline $\mathrm{H}$ & 2.011 & 8.943 & -4.713 & $\mathrm{C}$ & -5.731 & 3.526 & 2.541 & $\mathrm{H}$ & -3.433 & 5.905 & 3.164 \\
\hline $\mathrm{H}$ & 1.728 & 8.611 & -6.430 & $\mathrm{~N}$ & -5.523 & 2.882 & 3.838 & $\mathrm{H}$ & -0.030 & 3.736 & 4.633 \\
\hline $\mathrm{N}$ & 0.044 & 9.023 & -5.324 & $\mathrm{C}$ & -5.083 & 3.933 & 4.743 & $\mathrm{H}$ & -1.222 & 3.662 & 3.307 \\
\hline $\mathrm{C}$ & -1.005 & 8.534 & -6.206 & $\mathrm{H}$ & -5.298 & 3.623 & 5.776 & $\mathrm{H}$ & 1.184 & 2.755 & 1.481 \\
\hline $\mathrm{H}$ & -0.746 & 8.795 & -7.242 & $\mathrm{~N}$ & -3.692 & 4.395 & 4.639 & $\mathrm{H}$ & 2.843 & 2.917 & 2.121 \\
\hline $\mathrm{N}$ & -1.369 & 7.113 & -6.122 & $\mathrm{C}$ & -3.668 & 5.797 & 4.239 & $\mathrm{H}$ & 2.380 & 3.718 & -1.245 \\
\hline $\mathrm{C}$ & -2.752 & 6.985 & -5.680 & $\mathrm{C}$ & -4.819 & 1.610 & 3.866 & $\mathrm{H}$ & 4.037 & 4.379 & -1.280 \\
\hline $\mathrm{N}$ & -3.327 & 8.304 & -5.944 & & & & & & & & \\
\hline
\end{tabular}




\begin{tabular}{|c|c|c|c|c|c|c|c|c|c|c|c|}
\hline \multicolumn{12}{|c|}{$\mathrm{CB}[8] \mathrm{A}-\mathrm{H}+\mathrm{N} 2$} \\
\hline $\mathrm{C}$ & -0.063 & 0.066 & -0.007 & $\mathrm{C}$ & -2.235 & 9.311 & -5.798 & $\mathrm{H}$ & -5.044 & 1.166 & 4.981 \\
\hline $\mathrm{N}$ & -0.065 & 0.074 & 1.451 & $\mathrm{H}$ & -2.468 & 10.252 & -6.316 & $\mathrm{C}$ & -2.825 & 3.808 & 5.752 \\
\hline $\mathrm{C}$ & 1.320 & 0.085 & 1.947 & $\mathrm{~N}$ & -1.890 & 9.582 & -4.390 & $\mathrm{H}$ & -2.192 & 4.618 & 6.135 \\
\hline $\mathrm{H}$ & 1.516 & -0.825 & 2.532 & $\mathrm{C}$ & -0.510 & 9.168 & -4.132 & $\mathrm{H}$ & -3.365 & 3.380 & 6.611 \\
\hline $\mathrm{N}$ & 1.755 & 1.240 & 2.716 & $\mathrm{C}$ & -2.442 & 10.750 & -3.761 & $\mathrm{~N}$ & -1.940 & 2.769 & 5.263 \\
\hline $\mathrm{C}$ & 1.996 & 2.307 & 1.745 & $\mathrm{H}$ & -1.673 & 11.264 & -3.171 & $\mathrm{C}$ & -2.528 & 1.528 & 4.786 \\
\hline $\mathrm{N}$ & 2.511 & 1.608 & 0.574 & $\mathrm{H}$ & -2.812 & 11.462 & -4.512 & $\mathrm{H}$ & -2.991 & 1.004 & 5.634 \\
\hline $\mathrm{C}$ & 2.168 & 0.179 & 0.662 & $\mathrm{C}$ & -4.610 & 8.610 & -5.532 & $\mathrm{~N}$ & -3.476 & 1.609 & 3.665 \\
\hline $\mathrm{H}$ & 3.086 & -0.423 & 0.701 & $\mathrm{H}$ & -4.943 & 9.572 & -5.951 & $\mathrm{C}$ & -2.948 & 0.872 & 2.520 \\
\hline $\mathrm{N}$ & 1.287 & -0.374 & -0.355 & $\mathrm{H}$ & -5.279 & 7.834 & -5.921 & $\mathrm{~N}$ & -1.920 & 0.014 & 3.102 \\
\hline C & 1.703 & -0.296 & -1.745 & $\mathrm{~N}$ & -4.775 & 8.659 & -4.065 & $\mathrm{C}$ & -1.322 & 0.776 & 4.187 \\
\hline $\mathrm{H}$ & 0.930 & -0.797 & -2.340 & $\mathrm{C}$ & -4.809 & 9.976 & -3.429 & $\mathrm{H}$ & -0.851 & 0.077 & 4.892 \\
\hline $\mathrm{H}$ & 2.621 & -0.899 & -1.826 & $\mathrm{H}$ & -5.214 & 10.738 & -4.109 & $\mathrm{~N}$ & -0.380 & 1.853 & 3.842 \\
\hline C & 3.807 & 1.954 & 0.012 & $\mathrm{~N}$ & -3.577 & 10.508 & -2.848 & $\mathrm{C}$ & -0.907 & 3.133 & 4.292 \\
\hline $\mathrm{H}$ & 4.476 & 1.082 & 0.080 & $\mathrm{C}$ & -3.273 & 9.681 & -1.704 & $\mathrm{C}$ & -1.039 & -0.706 & 2.195 \\
\hline $\mathrm{H}$ & 4.256 & 2.757 & 0.609 & $\mathrm{~N}$ & -4.609 & 9.485 & -1.047 & $\mathrm{H}$ & -1.680 & -1.251 & 1.492 \\
\hline $\mathrm{N}$ & 3.844 & 2.385 & -1.376 & $\mathrm{C}$ & -5.705 & 9.741 & -2.214 & $\mathrm{H}$ & -0.515 & -1.456 & 2.809 \\
\hline C & 3.347 & 1.475 & -2.397 & $\mathrm{H}$ & -6.281 & 10.604 & -1.876 & $\mathrm{C}$ & 1.045 & 1.563 & 3.940 \\
\hline $\mathrm{H}$ & 4.015 & 0.605 & -2.451 & $\mathrm{~N}$ & -6.480 & 8.613 & -2.506 & $\mathrm{H}$ & 1.193 & 0.707 & 4.618 \\
\hline $\mathrm{N}$ & 1.950 & 1.027 & -2.301 & $\mathrm{C}$ & -5.704 & 7.747 & -3.414 & $\mathrm{H}$ & 1.553 & 2.425 & 4.389 \\
\hline C & 1.200 & 1.500 & -3.456 & $\mathrm{C}$ & -7.286 & 8.020 & -1.439 & $\mathrm{H}$ & -5.182 & 6.948 & -2.855 \\
\hline $\mathrm{N}$ & 2.234 & 1.835 & -4.435 & $\mathrm{H}$ & -8.095 & 8.726 & -1.211 & $\mathrm{H}$ & -6.379 & 7.264 & -4.133 \\
\hline C & 3.367 & 2.340 & -3.675 & $\mathrm{H}$ & -7.743 & 7.112 & -1.839 & $\mathrm{H}$ & -2.787 & 6.681 & -4.819 \\
\hline $\mathrm{H}$ & 4.280 & 2.212 & -4.273 & $\mathrm{C}$ & -4.916 & 10.258 & 0.268 & $\mathrm{H}$ & -3.243 & 6.286 & -6.499 \\
\hline $\mathrm{N}$ & 3.292 & 3.718 & -3.166 & $\mathrm{H}$ & -3.969 & 10.659 & 0.635 & $\mathrm{H}$ & -0.454 & 4.747 & -5.026 \\
\hline $\mathrm{C}$ & 3.308 & 3.703 & -1.708 & $\mathrm{H}$ & -5.566 & 11.090 & -0.015 & $\mathrm{H}$ & -0.449 & 3.573 & -6.371 \\
\hline $\mathrm{C}$ & 3.991 & 4.751 & -3.908 & $\mathrm{~N}$ & -5.520 & 9.444 & 1.257 & $\mathrm{H}$ & 0.577 & 2.378 & -3.201 \\
\hline $\mathrm{H}$ & 4.760 & 4.287 & -4.545 & $\mathrm{C}$ & -6.701 & 8.660 & 0.918 & $\mathrm{H}$ & 0.537 & 0.717 & -3.853 \\
\hline $\mathrm{H}$ & 4.508 & 5.417 & -3.206 & $\mathrm{H}$ & -7.548 & 9.325 & 0.719 & $\mathrm{H}$ & -0.810 & -0.636 & -0.406 \\
\hline $\mathrm{C}$ & 1.843 & 2.543 & -5.641 & $\mathrm{~N}$ & -6.519 & 7.708 & -0.223 & $\mathrm{H}$ & -0.285 & 1.071 & -0.415 \\
\hline $\mathrm{H}$ & 2.698 & 2.473 & -6.332 & $\mathrm{C}$ & -6.619 & 6.341 & 0.333 & $\mathrm{H}$ & -3.729 & 0.265 & 2.040 \\
\hline $\mathrm{H}$ & 1.014 & 1.982 & -6.089 & $\mathrm{~N}$ & -7.388 & 6.512 & 1.556 & $\mathrm{H}$ & -2.530 & 1.558 & 1.760 \\
\hline $\mathrm{N}$ & 1.454 & 3.941 & -5.510 & $\mathrm{C}$ & -6.908 & 7.752 & 2.152 & $\mathrm{H}$ & -6.484 & 2.958 & 2.037 \\
\hline $\mathrm{C}$ & 2.446 & 4.966 & -5.863 & $\mathrm{H}$ & -7.675 & 8.125 & 2.844 & $\mathrm{H}$ & -4.810 & 3.580 & 2.109 \\
\hline $\mathrm{H}$ & 3.158 & 4.560 & -6.595 & $\mathrm{~N}$ & -5.599 & 7.758 & 2.805 & $\mathrm{H}$ & -7.132 & 5.668 & -0.363 \\
\hline $\mathrm{N}$ & 3.195 & 5.598 & -4.786 & $\mathrm{C}$ & -4.660 & 8.595 & 2.107 & $\mathrm{H}$ & -5.611 & 5.940 & 0.527 \\
\hline $\mathrm{C}$ & 2.285 & 6.556 & -4.165 & $\mathrm{C}$ & -7.501 & 5.334 & 2.426 & $\mathrm{H}$ & 1.649 & 6.079 & -3.396 \\
\hline $\mathrm{N}$ & 1.485 & 7.051 & -5.282 & $\mathrm{H}$ & -8.211 & 5.609 & 3.219 & $\mathrm{H}$ & 2.850 & 7.369 & -3.688 \\
\hline $\mathrm{C}$ & 1.591 & 6.124 & -6.418 & $\mathrm{H}$ & -7.974 & 4.548 & 1.825 & $\mathrm{H}$ & -0.478 & 8.195 & -3.607 \\
\hline $\mathrm{H}$ & 2.051 & 6.632 & -7.277 & $\mathrm{C}$ & -5.508 & 7.552 & 4.254 & $\mathrm{H}$ & 0.022 & 9.910 & -3.520 \\
\hline $\mathrm{N}$ & 0.376 & 5.459 & -6.859 & $\mathrm{H}$ & -6.488 & 7.782 & 4.694 & $\mathrm{H}$ & -2.575 & 10.177 & -1.025 \\
\hline $\mathrm{C}$ & 0.124 & 4.384 & -5.898 & $\mathrm{H}$ & -4.787 & 8.272 & 4.661 & $\mathrm{H}$ & -2.886 & 8.686 & -1.972 \\
\hline $\mathrm{C}$ & -0.742 & 6.280 & -7.279 & $\mathrm{~N}$ & -5.129 & 6.242 & 4.725 & $\mathrm{H}$ & -4.079 & 9.222 & 2.798 \\
\hline $\mathrm{H}$ & -1.522 & 5.603 & -7.650 & $\mathrm{C}$ & -6.004 & 5.120 & 4.423 & $\mathrm{H}$ & -3.938 & 8.011 & 1.497 \\
\hline $\mathrm{H}$ & -0.391 & 6.876 & -8.135 & $\mathrm{H}$ & -6.947 & 5.245 & 4.972 & $\mathrm{H}$ & -3.050 & 6.334 & 5.106 \\
\hline $\mathrm{C}$ & 1.400 & 8.467 & -5.565 & $\mathrm{~N}$ & -6.274 & 4.839 & 3.005 & $\mathrm{H}$ & -3.468 & 5.936 & 3.417 \\
\hline $\mathrm{H}$ & 2.060 & 9.020 & -4.885 & $\mathrm{C}$ & -5.766 & 3.511 & 2.660 & $\mathrm{H}$ & -0.128 & 3.742 & 4.772 \\
\hline $\mathrm{H}$ & 1.749 & 8.663 & -6.590 & $\mathrm{~N}$ & -5.602 & 2.858 & 3.953 & $\mathrm{H}$ & -1.327 & 3.716 & 3.450 \\
\hline $\mathrm{N}$ & 0.078 & 9.086 & -5.462 & $\mathrm{C}$ & -5.184 & 3.897 & 4.883 & $\mathrm{H}$ & 1.067 & 2.860 & 1.507 \\
\hline $\mathrm{C}$ & -0.976 & 8.603 & -6.344 & $\mathrm{H}$ & -5.423 & 3.570 & 5.904 & $\mathrm{H}$ & 2.730 & 3.025 & 2.139 \\
\hline $\mathrm{H}$ & -0.728 & 8.893 & -7.375 & $\mathrm{~N}$ & -3.795 & 4.371 & 4.818 & $\mathrm{H}$ & 2.293 & 3.851 & -1.293 \\
\hline $\mathrm{N}$ & -1.333 & 7.181 & -6.291 & $\mathrm{C}$ & -3.760 & 5.781 & 4.474 & $\mathrm{H}$ & 3.958 & 4.494 & -1.307 \\
\hline $\mathrm{C}$ & -2.713 & 7.018 & -5.872 & $\mathrm{C}$ & -4.893 & 1.583 & 3.974 & $\mathrm{H}$ & -4.773 & 8.498 & -0.790 \\
\hline 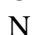 & 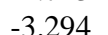 & - & 6.049 & 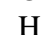 & $-5,409$ & 09 & 3267 & & & & \\
\hline
\end{tabular}




\begin{tabular}{|c|c|c|c|c|c|c|c|c|c|c|c|}
\hline \multicolumn{12}{|c|}{ CB[8]A-H+_N4 } \\
\hline $\mathrm{C}$ & 0.048 & -0.109 & 0.062 & $\mathrm{C}$ & -2.264 & 9.354 & -5.703 & $\mathrm{H}$ & -4.920 & 1.228 & 4.923 \\
\hline $\mathrm{N}$ & 0.070 & -0.102 & 1.517 & $\mathrm{H}$ & -2.404 & 10.304 & -6.235 & $\mathrm{C}$ & -2.645 & 3.905 & 5.550 \\
\hline $\mathrm{C}$ & 1.457 & -0.094 & 1.998 & $\mathrm{~N}$ & -1.993 & 9.639 & -4.263 & $\mathrm{H}$ & -1.993 & 4.728 & 5.868 \\
\hline $\mathrm{H}$ & 1.650 & -0.995 & 2.597 & $\mathrm{C}$ & -0.679 & 9.074 & -3.908 & $\mathrm{H}$ & -3.189 & 3.555 & 6.441 \\
\hline $\mathrm{N}$ & 1.912 & 1.070 & 2.747 & $\mathrm{C}$ & -2.403 & 10.872 & -3.747 & $\mathrm{~N}$ & -1.784 & 2.812 & 5.142 \\
\hline $\mathrm{C}$ & 2.174 & 2.116 & 1.760 & $\mathrm{H}$ & -1.659 & 11.312 & -3.074 & $\mathrm{C}$ & -2.398 & 1.557 & 4.738 \\
\hline $\mathrm{N}$ & 2.673 & 1.386 & 0.604 & $\mathrm{H}$ & -2.649 & 11.604 & -4.530 & $\mathrm{H}$ & -2.883 & 1.101 & 5.612 \\
\hline $\mathrm{C}$ & 2.294 & -0.029 & 0.701 & $\mathrm{C}$ & -4.672 & 8.818 & -5.556 & $\mathrm{~N}$ & -3.333 & 1.587 & 3.604 \\
\hline $\mathrm{H}$ & 3.196 & -0.656 & 0.733 & $\mathrm{H}$ & -4.936 & 9.767 & -6.043 & $\mathrm{C}$ & -2.807 & 0.781 & 2.509 \\
\hline $\mathrm{N}$ & 1.389 & -0.562 & -0.307 & $\mathrm{H}$ & -5.368 & 8.055 & -5.920 & $\mathrm{~N}$ & -1.804 & -0.068 & 3.148 \\
\hline $\mathrm{C}$ & 1.781 & -0.469 & -1.703 & $\mathrm{~N}$ & -4.890 & 8.984 & -4.111 & $\mathrm{C}$ & -1.205 & 0.737 & 4.203 \\
\hline $\mathrm{H}$ & 1.001 & -0.970 & -2.289 & $\mathrm{C}$ & -5.025 & 10.258 & -3.541 & $\mathrm{H}$ & -0.767 & 0.065 & 4.954 \\
\hline $\mathrm{H}$ & 2.702 & -1.064 & -1.807 & $\mathrm{H}$ & -5.342 & 11.035 & -4.246 & $\mathrm{~N}$ & -0.226 & 1.762 & 3.817 \\
\hline $\mathrm{C}$ & 3.953 & 1.713 & 0.005 & $\mathrm{~N}$ & -3.700 & 10.832 & -2.886 & $\mathrm{C}$ & -0.729 & 3.084 & 4.165 \\
\hline $\mathrm{H}$ & 4.599 & 0.822 & 0.019 & $\mathrm{C}$ & -3.664 & 10.111 & -1.552 & $\mathrm{C}$ & -0.918 & -0.837 & 2.286 \\
\hline $\mathrm{H}$ & 4.450 & 2.484 & 0.608 & $\mathrm{~N}$ & -5.027 & 10.175 & -1.150 & $\mathrm{H}$ & -1.556 & -1.411 & 1.602 \\
\hline $\mathrm{N}$ & 3.946 & 2.190 & -1.371 & $\mathrm{C}$ & -5.943 & 10.068 & -2.290 & $\mathrm{H}$ & -0.404 & -1.559 & 2.939 \\
\hline $\mathrm{C}$ & 3.400 & 1.314 & -2.399 & $\mathrm{H}$ & -6.713 & 10.842 & -2.186 & $\mathrm{C}$ & 1.186 & 1.440 & 3.952 \\
\hline $\mathrm{H}$ & 4.068 & 0.449 & -2.515 & $\mathrm{~N}$ & -6.585 & 8.805 & -2.596 & $\mathrm{H}$ & 1.297 & 0.597 & 4.651 \\
\hline $\mathrm{N}$ & 2.011 & 0.859 & -2.254 & $\mathrm{C}$ & -5.617 & 7.990 & -3.317 & $\mathrm{H}$ & 1.711 & 2.298 & 4.390 \\
\hline $\mathrm{C}$ & 1.205 & 1.362 & -3.357 & $\mathrm{C}$ & -7.402 & 8.169 & -1.561 & $\mathrm{H}$ & -4.942 & 7.429 & -2.647 \\
\hline $\mathrm{N}$ & 2.192 & 1.744 & -4.368 & $\mathrm{H}$ & -8.219 & 8.874 & -1.346 & $\mathrm{H}$ & -6.124 & 7.273 & -3.974 \\
\hline $\mathrm{C}$ & 3.357 & 2.225 & -3.644 & $\mathrm{H}$ & -7.854 & 7.283 & -2.021 & $\mathrm{H}$ & -3.014 & 6.765 & -4.732 \\
\hline $\mathrm{H}$ & 4.242 & 2.125 & -4.288 & $\mathrm{C}$ & -5.475 & 10.596 & 0.185 & $\mathrm{H}$ & -3.384 & 6.389 & -6.435 \\
\hline $\mathrm{N}$ & 3.299 & 3.583 & -3.080 & $\mathrm{H}$ & -4.685 & 11.218 & 0.625 & $\mathrm{H}$ & -0.551 & 4.662 & -4.821 \\
\hline $\mathrm{C}$ & 3.383 & 3.513 & -1.626 & $\mathrm{H}$ & -6.356 & 11.234 & 0.033 & $\mathrm{H}$ & -0.556 & 3.531 & -6.202 \\
\hline $\mathrm{C}$ & 3.961 & 4.645 & -3.810 & $\mathrm{~N}$ & -5.834 & 9.593 & 1.148 & $\mathrm{H}$ & 0.583 & 2.224 & -3.046 \\
\hline $\mathrm{H}$ & 4.707 & 4.215 & -4.496 & $\mathrm{C}$ & -6.914 & 8.679 & 0.831 & $\mathrm{H}$ & 0.535 & 0.584 & -3.751 \\
\hline $\mathrm{H}$ & 4.500 & 5.291 & -3.106 & $\mathrm{H}$ & -7.851 & 9.244 & 0.732 & $\mathrm{H}$ & -0.712 & -0.805 & -0.323 \\
\hline $\mathrm{C}$ & 1.746 & 2.482 & -5.532 & $\mathrm{~N}$ & -6.722 & 7.799 & -0.338 & $\mathrm{H}$ & -0.171 & 0.896 & -0.346 \\
\hline $\mathrm{H}$ & 2.569 & 2.437 & -6.263 & $\mathrm{C}$ & -6.733 & 6.401 & 0.114 & $\mathrm{H}$ & -3.594 & 0.166 & 2.049 \\
\hline $\mathrm{H}$ & 0.899 & 1.932 & -5.960 & $\mathrm{~N}$ & -7.371 & 6.467 & 1.423 & $\mathrm{H}$ & -2.362 & 1.416 & 1.719 \\
\hline $\mathrm{N}$ & 1.355 & 3.878 & -5.346 & $\mathrm{C}$ & -6.915 & 7.707 & 2.025 & $\mathrm{H}$ & -6.327 & 2.902 & 1.899 \\
\hline $\mathrm{C}$ & 2.342 & 4.912 & -5.695 & $\mathrm{H}$ & -7.618 & 7.995 & 2.820 & $\mathrm{H}$ & -4.652 & 3.522 & 1.941 \\
\hline $\mathrm{H}$ & 3.032 & 4.530 & -6.461 & $\mathrm{~N}$ & -5.532 & 7.777 & 2.528 & $\mathrm{H}$ & -7.313 & 5.765 & -0.568 \\
\hline $\mathrm{N}$ & 3.120 & 5.514 & -4.624 & $\mathrm{C}$ & -4.791 & 8.798 & 1.806 & $\mathrm{H}$ & -5.705 & 6.001 & 0.173 \\
\hline $\mathrm{C}$ & 2.212 & 6.422 & -3.933 & $\mathrm{C}$ & -7.381 & 5.259 & 2.242 & $\mathrm{H}$ & 1.598 & 5.897 & -3.179 \\
\hline $\mathrm{N}$ & 1.374 & 6.963 & -5.006 & $\mathrm{H}$ & -8.091 & 5.454 & 3.061 & $\mathrm{H}$ & 2.776 & 7.218 & -3.426 \\
\hline $\mathrm{C}$ & 1.474 & 6.085 & -6.189 & $\mathrm{H}$ & -7.809 & 4.460 & 1.625 & $\mathrm{H}$ & -0.799 & 8.079 & -3.448 \\
\hline $\mathrm{H}$ & 1.922 & 6.636 & -7.028 & $\mathrm{C}$ & -5.327 & 7.597 & 3.968 & $\mathrm{H}$ & -0.142 & 9.725 & -3.207 \\
\hline $\mathrm{N}$ & 0.260 & 5.433 & -6.640 & $\mathrm{H}$ & -6.262 & 7.848 & 4.493 & $\mathrm{H}$ & -3.000 & 10.633 & -0.854 \\
\hline $\mathrm{C}$ & 0.019 & 4.328 & -5.709 & $\mathrm{H}$ & -4.562 & 8.307 & 4.304 & $\mathrm{H}$ & -3.262 & 9.112 & -1.761 \\
\hline $\mathrm{C}$ & -0.848 & 6.247 & -7.076 & $\mathrm{~N}$ & -4.933 & 6.287 & 4.435 & $\mathrm{H}$ & -4.201 & 9.430 & 2.485 \\
\hline $\mathrm{H}$ & -1.634 & 5.571 & -7.433 & $\mathrm{C}$ & -5.817 & 5.163 & 4.186 & $\mathrm{H}$ & -4.095 & 8.346 & 1.070 \\
\hline $\mathrm{H}$ & -0.493 & 6.826 & -7.943 & $\mathrm{H}$ & -6.754 & 5.314 & 4.740 & $\mathrm{H}$ & -2.844 & 6.387 & 4.752 \\
\hline $\mathrm{C}$ & 1.322 & 8.388 & -5.240 & $\mathrm{~N}$ & -6.108 & 4.824 & 2.782 & $\mathrm{H}$ & -3.312 & 5.913 & 3.094 \\
\hline $\mathrm{H}$ & 1.943 & 8.907 & -4.500 & $\mathrm{C}$ & -5.607 & 3.480 & 2.496 & $\mathrm{H}$ & 0.058 & 3.708 & 4.613 \\
\hline $\mathrm{H}$ & 1.729 & 8.629 & -6.234 & $\mathrm{~N}$ & -5.441 & 2.881 & 3.816 & $\mathrm{H}$ & -1.123 & 3.614 & 3.277 \\
\hline $\mathrm{N}$ & 0.000 & 9.018 & -5.192 & $\mathrm{C}$ & -4.999 & 3.956 & 4.689 & $\mathrm{H}$ & 1.259 & 2.687 & 1.514 \\
\hline $\mathrm{C}$ & -1.008 & 8.576 & -6.147 & $\mathrm{H}$ & -5.222 & 3.683 & 5.729 & $\mathrm{H}$ & 2.925 & 2.823 & 2.140 \\
\hline $\mathrm{H}$ & -0.671 & 8.843 & -7.158 & $\mathrm{~N}$ & -3.606 & 4.414 & 4.576 & $\mathrm{H}$ & 2.386 & 3.631 & -1.161 \\
\hline $\mathrm{N}$ & -1.442 & 7.176 & -6.105 & $\mathrm{C}$ & -3.575 & 5.811 & 4.165 & $\mathrm{H}$ & 4.043 & 4.295 & -1.225 \\
\hline $\mathrm{C}$ & -2.855 & 7.091 & -5.778 & $\mathrm{C}$ & -4.754 & 1.599 & 3.899 & $\mathrm{H}$ & -3.916 & 11.810 & -2.668 \\
\hline $\mathrm{N}$ & -3.349 & 8.458 & -5.995 & $\mathrm{H}$ & -5.273 & 0.914 & 3.217 & & & & \\
\hline
\end{tabular}




\begin{tabular}{|c|c|c|c|c|c|c|c|c|c|c|c|}
\hline \multicolumn{12}{|c|}{ CB[10] } \\
\hline $\mathrm{O}$ & 0.012 & -0.124 & 0.036 & $\mathrm{~N}$ & -7.803 & 9.040 & -1.995 & $\mathrm{C}$ & 4.933 & 12.889 & 0.313 \\
\hline C & 0.004 & -0.067 & 1.251 & C & -8.584 & 9.325 & -0.809 & $\mathrm{H}$ & 5.752 & 13.574 & 0.035 \\
\hline $\mathrm{N}$ & 1.119 & 0.064 & 2.076 & $\mathrm{H}$ & -9.484 & 9.901 & -1.082 & $\mathrm{H}$ & 4.638 & 13.069 & 1.349 \\
\hline C & 0.794 & -0.124 & 3.474 & $\mathrm{~N}$ & -7.892 & 9.982 & 0.279 & $\mathrm{C}$ & 5.096 & 11.490 & -3.090 \\
\hline $\mathrm{H}$ & 1.331 & -1.002 & 3.868 & C & -7.853 & 9.198 & 1.431 & $\mathrm{H}$ & 4.891 & 10.881 & -3.973 \\
\hline $\mathrm{N}$ & 1.003 & 1.012 & 4.347 & $\mathrm{O}$ & -7.490 & 9.560 & 2.533 & $\mathrm{H}$ & 5.907 & 12.205 & -3.310 \\
\hline C & -0.180 & 1.438 & 4.950 & C & -7.725 & 11.418 & 0.356 & $\mathrm{~N}$ & 5.533 & 10.593 & -2.042 \\
\hline $\mathrm{O}$ & -0.275 & 2.242 & 5.857 & $\mathrm{H}$ & -7.467 & 11.660 & 1.389 & $\mathrm{C}$ & 6.234 & 11.042 & -0.858 \\
\hline $\mathrm{N}$ & -1.229 & 0.736 & 4.359 & $\mathrm{H}$ & -8.680 & 11.903 & 0.089 & $\mathrm{H}$ & 6.980 & 11.806 & -1.132 \\
\hline C & -0.761 & -0.306 & 3.470 & C & -7.589 & 10.010 & -3.049 & $\mathrm{~N}$ & 5.415 & 11.526 & 0.235 \\
\hline $\mathrm{H}$ & -1.082 & -1.291 & 3.847 & $\mathrm{H}$ & -7.254 & 9.460 & -3.932 & $\mathrm{C}$ & 5.574 & 10.762 & 1.390 \\
\hline $\mathrm{N}$ & -1.117 & -0.174 & 2.073 & $\mathrm{H}$ & -8.543 & 10.518 & -3.268 & $\mathrm{O}$ & 5.155 & 11.039 & 2.497 \\
\hline C & -2.382 & -0.631 & 1.537 & $\mathrm{~N}$ & -6.676 & 11.954 & -0.485 & $\mathrm{~N}$ & 6.346 & 9.651 & 1.056 \\
\hline $\mathrm{H}$ & -2.268 & -0.705 & 0.453 & C & -6.832 & 12.156 & -1.910 & $\mathrm{C}$ & 6.873 & 9.732 & -0.289 \\
\hline $\mathrm{H}$ & -2.608 & -1.627 & 1.955 & $\mathrm{H}$ & -7.833 & 12.567 & -2.122 & $\mathrm{H}$ & 7.975 & 9.766 & -0.258 \\
\hline C & -2.546 & 0.729 & 4.959 & $\mathrm{~N}$ & -6.583 & 11.010 & -2.758 & $\mathrm{~N}$ & 6.441 & 8.708 & -1.218 \\
\hline $\mathrm{H}$ & -2.767 & -0.288 & 5.326 & C & -5.516 & 11.220 & -3.631 & $\mathrm{C}$ & 5.745 & 9.241 & -2.302 \\
\hline $\mathrm{H}$ & -2.523 & 1.426 & 5.800 & $\mathrm{O}$ & -5.197 & 10.506 & -4.561 & $\mathrm{O}$ & 5.422 & 8.644 & -3.311 \\
\hline $\mathrm{N}$ & -3.615 & 1.153 & 4.081 & $\mathrm{~N}$ & -4.913 & 12.425 & -3.274 & $\mathrm{C}$ & 7.076 & 7.411 & -1.315 \\
\hline C & -4.474 & 2.186 & 4.451 & C & -5.674 & 13.144 & -2.272 & $\mathrm{H}$ & 8.171 & 7.547 & -1.286 \\
\hline $\mathrm{O}$ & -4.324 & 2.943 & 5.391 & $\mathrm{H}$ & -6.034 & 14.098 & -2.690 & $\mathrm{H}$ & 6.784 & 6.978 & -2.274 \\
\hline $\mathrm{N}$ & -5.562 & 2.162 & 3.580 & $\mathrm{~N}$ & -5.016 & 13.379 & -1.005 & $\mathrm{C}$ & 6.927 & 8.815 & 2.086 \\
\hline C & -5.552 & 0.992 & 2.725 & C & -5.675 & 12.760 & 0.056 & $\mathrm{H}$ & 6.549 & 9.174 & 3.046 \\
\hline $\mathrm{H}$ & -6.428 & 0.361 & 2.946 & $\mathrm{O}$ & -5.448 & 12.927 & 1.238 & $\mathrm{H}$ & 8.024 & 8.923 & 2.054 \\
\hline $\mathrm{N}$ & -5.466 & 1.231 & 1.301 & $\mathrm{C}$ & -3.969 & 13.072 & -4.160 & $\mathrm{~N}$ & 6.592 & 7.410 & 1.990 \\
\hline C & -4.303 & 0.701 & 0.744 & $\mathrm{H}$ & -4.417 & 14.006 & -4.539 & $\mathrm{C}$ & 7.235 & 6.508 & 1.058 \\
\hline $\mathrm{O}$ & -4.052 & 0.610 & -0.442 & $\mathrm{H}$ & -3.786 & 12.388 & -4.992 & $\mathrm{H}$ & 8.316 & 6.717 & 1.020 \\
\hline $\mathrm{N}$ & -3.504 & 0.249 & 1.793 & C & -4.132 & 14.502 & -0.770 & $\mathrm{~N}$ & 6.694 & 6.470 & -0.284 \\
\hline C & -4.191 & 0.297 & 3.066 & $\mathrm{H}$ & -4.040 & 14.621 & 0.312 & $\mathrm{C}$ & 6.201 & 5.210 & -0.620 \\
\hline $\mathrm{H}$ & -4.314 & -0.724 & 3.463 & $\mathrm{H}$ & -4.583 & 15.408 & -1.207 & $\mathrm{O}$ & 5.855 & 4.845 & -1.726 \\
\hline C & -6.618 & 1.524 & 0.475 & $\mathrm{~N}$ & -2.794 & 14.343 & -1.299 & $\mathrm{~N}$ & 6.226 & 4.428 & 0.534 \\
\hline $\mathrm{H}$ & -6.326 & 1.349 & -0.563 & $\mathrm{C}$ & -2.472 & 14.519 & -2.700 & $\mathrm{C}$ & 6.904 & 5.089 & 1.630 \\
\hline $\mathrm{H}$ & -7.437 & 0.838 & 0.751 & $\mathrm{H}$ & -3.009 & 15.395 & -3.099 & $\mathrm{H}$ & 7.802 & 4.517 & 1.913 \\
\hline C & -6.768 & 2.902 & 3.887 & $\mathrm{~N}$ & -2.687 & 13.376 & -3.563 & $\mathrm{~N}$ & 6.109 & 5.371 & 2.807 \\
\hline $\mathrm{H}$ & -6.560 & 3.506 & 4.773 & $\mathrm{C}$ & -1.505 & 12.936 & -4.157 & $\mathrm{C}$ & 6.022 & 6.737 & 3.070 \\
\hline $\mathrm{H}$ & -7.580 & 2.188 & 4.105 & $\mathrm{O}$ & -1.414 & 12.119 & -5.053 & $\mathrm{O}$ & 5.573 & 7.248 & 4.077 \\
\hline $\mathrm{N}$ & -7.098 & 2.887 & 0.562 & $\mathrm{~N}$ & -0.453 & 13.638 & -3.573 & $\mathrm{C}$ & 5.888 & 4.402 & 3.859 \\
\hline C & -7.912 & 3.365 & 1.661 & C & -0.917 & 14.697 & -2.701 & $\mathrm{H}$ & 5.543 & 4.952 & 4.738 \\
\hline $\mathrm{H}$ & -8.659 & 2.601 & 1.933 & $\mathrm{H}$ & -0.594 & 15.674 & -3.096 & $\mathrm{H}$ & 6.842 & 3.898 & 4.088 \\
\hline $\mathrm{N}$ & -7.207 & 3.805 & 2.845 & $\mathrm{~N}$ & -0.559 & 14.588 & -1.303 & $\mathrm{C}$ & 6.066 & 2.992 & 0.457 \\
\hline C & -7.404 & 5.159 & 3.108 & $\mathrm{C}$ & -1.678 & 14.490 & -0.477 & $\mathrm{H}$ & 5.818 & 2.748 & -0.578 \\
\hline $\mathrm{O}$ & -7.069 & 5.751 & 4.116 & $\mathrm{O}$ & -1.684 & 14.563 & 0.736 & $\mathrm{H}$ & 7.019 & 2.510 & 0.734 \\
\hline $\mathrm{N}$ & -8.100 & 5.699 & 2.028 & $\mathrm{C}$ & 0.708 & 15.052 & -0.776 & $\mathrm{~N}$ & 5.010 & 2.454 & 1.289 \\
\hline C & -8.552 & 4.680 & 1.103 & $\mathrm{H}$ & 0.596 & 15.143 & 0.306 & $\mathrm{C}$ & 5.152 & 2.253 & 2.715 \\
\hline $\mathrm{H}$ & -9.654 & 4.652 & 1.087 & $\mathrm{H}$ & 0.934 & 16.041 & -1.210 & $\mathrm{H}$ & 6.152 & 1.846 & 2.938 \\
\hline $\mathrm{N}$ & -8.043 & 4.760 & -0.249 & C & 0.863 & 13.633 & -4.176 & $\mathrm{~N}$ & 4.888 & 3.399 & 3.560 \\
\hline C & -7.272 & 3.651 & -0.592 & $\mathrm{H}$ & 0.837 & 12.923 & -5.005 & $\mathrm{C}$ & 3.821 & 3.178 & 4.430 \\
\hline $\mathrm{O}$ & -6.863 & 3.377 & -1.703 & $\mathrm{H}$ & 1.084 & 14.644 & -4.559 & $\mathrm{O}$ & 3.494 & 3.888 & 5.361 \\
\hline C & -8.632 & 5.600 & -1.270 & $\mathrm{~N}$ & 1.933 & 13.221 & -3.292 & $\mathrm{~N}$ & 3.229 & 1.969 & 4.070 \\
\hline $\mathrm{H}$ & -9.730 & 5.498 & -1.225 & C & 2.512 & 14.096 & -2.294 & $\mathrm{C}$ & 3.993 & 1.261 & 3.065 \\
\hline $\mathrm{H}$ & -8.268 & 5.240 & -2.235 & $\mathrm{H}$ & 2.636 & 15.109 & -2.710 & $\mathrm{H}$ & 4.353 & 0.303 & 3.475 \\
\hline C & -8.727 & 7.000 & 2.134 & $\mathrm{~N}$ & 1.828 & 14.168 & -1.020 & $\mathrm{~N}$ & 3.339 & 1.035 & 1.793 \\
\hline $\mathrm{H}$ & -9.823 & 6.871 & 2.120 & $\mathrm{C}$ & 2.623 & 13.720 & 0.033 & $\mathrm{C}$ & 4.010 & 1.654 & 0.739 \\
\hline $\mathrm{H}$ & -8.420 & 7.431 & 3.090 & $\mathrm{O}$ & 2.372 & 13.826 & 1.218 & $\mathrm{O}$ & 3.791 & 1.490 & -0.446 \\
\hline $\mathrm{N}$ & -8.353 & 7.940 & 1.100 & $\mathrm{~N}$ & 3.782 & 13.175 & -0.517 & $\mathrm{C}$ & 2.284 & 1.315 & 4.950 \\
\hline C & -8.914 & 7.907 & -0.235 & C & 3.873 & 13.405 & -1.944 & $\mathrm{H}$ & 2.733 & 0.378 & 5.323 \\
\hline $\mathrm{H}$ & -9.995 & 7.703 & -0.181 & $\mathrm{H}$ & 4.749 & 14.037 & -2.165 & $\mathrm{H}$ & 2.097 & 1.992 & 5.786 \\
\hline $\mathrm{N}$ & -8.289 & 7.003 & -1.177 & $\mathrm{~N}$ & 3.889 & 12.231 & -2.790 & $\mathrm{C}$ & 2.457 & -0.087 & 1.548 \\
\hline C & -7.729 & 7.674 & -2.262 & $\mathrm{C}$ & 2.797 & 12.189 & -3.655 & $\mathrm{H}$ & 2.910 & -0.997 & 1.978 \\
\hline $\mathrm{O}$ & -7.296 & 7.163 & -3.277 & $\mathrm{O}$ & 2.646 & 11.421 & -4.585 & $\mathrm{H}$ & 2.367 & -0.198 & 0.465 \\
\hline
\end{tabular}




\begin{tabular}{|c|c|c|c|c|c|c|c|c|c|c|c|}
\hline \multicolumn{12}{|c|}{$\mathrm{CB}[10]-\mathrm{H}+$-N2 } \\
\hline $\mathrm{O}$ & 0.025 & 0.013 & -0.002 & $\mathrm{C}$ & -8.565 & 9.715 & 0.251 & $\mathrm{H}$ & 6.401 & 13.340 & -0.849 \\
\hline C & 0.021 & 0.007 & 1.214 & $\mathrm{H}$ & -9.432 & 10.394 & 0.237 & $\mathrm{H}$ & 5.502 & 13.083 & 0.683 \\
\hline $\mathrm{N}$ & 1.142 & -0.001 & 2.039 & $\mathrm{~N}$ & -7.607 & 10.143 & 1.256 & $\mathrm{C}$ & 5.091 & 10.953 & -3.517 \\
\hline C & 0.801 & -0.145 & 3.434 & $\mathrm{C}$ & -7.552 & 9.250 & 2.339 & $\mathrm{H}$ & 4.708 & 10.267 & -4.276 \\
\hline $\mathrm{H}$ & 1.331 & -1.010 & 3.864 & $\mathrm{O}$ & -6.994 & 9.460 & 3.396 & $\mathrm{H}$ & 5.889 & 11.577 & -3.952 \\
\hline $\mathrm{N}$ & 0.999 & 1.026 & 4.273 & $\mathrm{C}$ & -7.250 & 11.521 & 1.455 & $\mathrm{~N}$ & 5.627 & 10.147 & -2.447 \\
\hline C & -0.173 & 1.385 & 4.942 & $\mathrm{H}$ & -6.827 & 11.605 & 2.460 & $\mathrm{C}$ & 6.556 & 10.672 & -1.461 \\
\hline $\mathrm{O}$ & -0.265 & 2.178 & 5.858 & $\mathrm{H}$ & -8.143 & 12.160 & 1.374 & $\mathrm{H}$ & 7.313 & 11.306 & -1.949 \\
\hline $\mathrm{N}$ & -1.211 & 0.630 & 4.402 & $\mathrm{C}$ & -7.864 & 10.600 & -2.031 & $\mathrm{~N}$ & 5.967 & 11.371 & -0.344 \\
\hline $\mathrm{C}$ & -0.752 & -0.321 & 3.418 & $\mathrm{H}$ & -7.772 & 10.144 & -3.020 & $\mathrm{C}$ & 6.062 & 10.650 & 0.850 \\
\hline $\mathrm{H}$ & -1.075 & -1.337 & 3.696 & $\mathrm{H}$ & -8.738 & 11.267 & -2.006 & $\mathrm{O}$ & 5.728 & 11.055 & 1.946 \\
\hline $\mathrm{N}$ & -1.107 & -0.045 & 2.036 & $\mathrm{~N}$ & -6.250 & 12.036 & 0.520 & $\mathrm{~N}$ & 6.648 & 9.426 & 0.553 \\
\hline C & -2.385 & -0.435 & 1.472 & C & -6.569 & 12.458 & -0.834 & C & 7.155 & 9.383 & -0.811 \\
\hline $\mathrm{H}$ & -2.280 & -0.400 & 0.386 & $\mathrm{H}$ & -7.493 & 13.055 & -0.823 & $\mathrm{H}$ & 8.256 & 9.373 & -0.802 \\
\hline $\mathrm{H}$ & -2.620 & -1.466 & 1.788 & $\mathrm{~N}$ & -6.664 & 11.413 & -1.831 & $\mathrm{~N}$ & 6.661 & 8.317 & -1.650 \\
\hline C & -2.517 & 0.587 & 5.018 & C & -5.719 & 11.541 & -2.832 & $\mathrm{C}$ & 5.799 & 8.769 & -2.639 \\
\hline $\mathrm{H}$ & -2.741 & -0.456 & 5.296 & $\mathrm{O}$ & -5.654 & 10.921 & -3.871 & $\mathrm{O}$ & 5.312 & 8.112 & -3.536 \\
\hline $\mathrm{H}$ & -2.477 & 1.207 & 5.917 & $\mathrm{~N}$ & -4.837 & 12.582 & -2.457 & $\mathrm{C}$ & 7.233 & 6.985 & -1.686 \\
\hline $\mathrm{N}$ & -3.597 & 1.099 & 4.197 & C & -5.311 & 13.283 & -1.283 & $\mathrm{H}$ & 8.331 & 7.083 & -1.699 \\
\hline C & -4.479 & 2.049 & 4.705 & $\mathrm{H}$ & -5.547 & 14.333 & -1.515 & $\mathrm{H}$ & 6.896 & 6.507 & -2.609 \\
\hline $\mathrm{O}$ & -4.337 & 2.693 & 5.727 & $\mathrm{~N}$ & -4.436 & 13.203 & -0.120 & $\mathrm{C}$ & 7.211 & 8.613 & 1.621 \\
\hline $\mathrm{N}$ & -5.582 & 2.095 & 3.854 & $\mathrm{C}$ & -5.039 & 12.504 & 0.963 & $\mathrm{H}$ & 6.864 & 9.042 & 2.564 \\
\hline C & -5.539 & 1.066 & 2.839 & $\mathrm{O}$ & -4.546 & 12.411 & 2.067 & $\mathrm{H}$ & 8.311 & 8.670 & 1.570 \\
\hline $\mathrm{H}$ & -6.410 & 0.399 & 2.941 & C & -4.038 & 13.210 & -3.484 & $\mathrm{~N}$ & 6.813 & 7.227 & 1.602 \\
\hline $\mathrm{N}$ & -5.424 & 1.521 & 1.467 & $\mathrm{H}$ & -4.440 & 14.205 & -3.729 & $\mathrm{C}$ & 7.405 & 6.235 & 0.736 \\
\hline C & -4.265 & 1.042 & 0.852 & $\mathrm{H}$ & -4.080 & 12.569 & -4.368 & $\mathrm{H}$ & 8.494 & 6.392 & 0.671 \\
\hline $\mathrm{O}$ & -4.002 & 1.117 & -0.333 & $\mathrm{C}$ & -3.342 & 14.055 & 0.147 & $\mathrm{~N}$ & 6.836 & 6.124 & -0.594 \\
\hline $\mathrm{N}$ & -3.493 & 0.424 & 1.831 & $\mathrm{H}$ & -3.027 & 13.909 & 1.184 & $\mathrm{C}$ & 6.368 & 4.834 & -0.857 \\
\hline C & -4.177 & 0.344 & 3.104 & $\mathrm{H}$ & -3.541 & 15.116 & -0.049 & $\mathrm{O}$ & 6.030 & 4.404 & -1.942 \\
\hline $\mathrm{H}$ & -4.297 & -0.711 & 3.398 & $\mathrm{~N}$ & -2.136 & 13.699 & -0.732 & $\mathrm{~N}$ & 6.410 & 4.125 & 0.338 \\
\hline C & -6.570 & 1.894 & 0.669 & C & -2.158 & 14.266 & -2.165 & $\mathrm{C}$ & 7.018 & 4.877 & 1.410 \\
\hline $\mathrm{H}$ & -6.261 & 1.867 & -0.378 & $\mathrm{H}$ & -2.716 & 15.205 & -2.107 & $\mathrm{H}$ & 7.886 & 4.329 & 1.809 \\
\hline $\mathrm{H}$ & -7.379 & 1.162 & 0.834 & $\mathrm{~N}$ & -2.630 & 13.362 & -3.129 & $\mathrm{~N}$ & 6.144 & 5.276 & 2.500 \\
\hline C & -6.796 & 2.777 & 4.244 & C & -1.565 & 12.792 & -3.864 & $\mathrm{C}$ & 6.126 & 6.658 & 2.675 \\
\hline $\mathrm{H}$ & -6.598 & 3.265 & 5.201 & $\mathrm{O}$ & -1.680 & 12.029 & -4.788 & $\mathrm{O}$ & 5.641 & 7.263 & 3.611 \\
\hline $\mathrm{H}$ & -7.603 & 2.038 & 4.363 & $\mathrm{~N}$ & -0.373 & 13.308 & -3.326 & $\mathrm{C}$ & 5.852 & 4.400 & 3.621 \\
\hline $\mathrm{N}$ & -7.084 & 3.227 & 0.931 & C & -0.660 & 14.456 & -2.489 & $\mathrm{H}$ & 5.460 & 5.024 & 4.427 \\
\hline C & -7.924 & 3.526 & 2.079 & $\mathrm{H}$ & -0.465 & 15.398 & -3.020 & $\mathrm{H}$ & 6.790 & 3.919 & 3.949 \\
\hline $\mathrm{H}$ & -8.659 & 2.719 & 2.225 & $\mathrm{~N}$ & -0.011 & 14.521 & -1.186 & C & 6.230 & 2.687 & 0.369 \\
\hline $\mathrm{N}$ & -7.243 & 3.804 & 3.322 & C & -0.777 & 14.168 & -0.133 & $\mathrm{H}$ & 6.029 & 2.363 & -0.654 \\
\hline C & -7.365 & 5.130 & 3.715 & $\mathrm{O}$ & -0.599 & 14.179 & 1.049 & $\mathrm{H}$ & 7.163 & 2.224 & 0.730 \\
\hline $\mathrm{O}$ & -6.995 & 5.612 & 4.767 & C & 1.362 & 15.057 & -1.000 & $\mathrm{~N}$ & 5.130 & 2.230 & 1.188 \\
\hline $\mathrm{N}$ & -8.042 & 5.808 & 2.696 & $\mathrm{H}$ & 1.471 & 15.310 & 0.057 & $\mathrm{C}$ & 5.186 & 2.157 & 2.630 \\
\hline C & -8.581 & 4.895 & 1.704 & $\mathrm{H}$ & 1.420 & 15.966 & -1.614 & $\mathrm{H}$ & 6.170 & 1.779 & 2.951 \\
\hline $\mathrm{H}$ & -9.681 & 4.879 & 1.761 & C & 0.849 & 13.242 & -4.146 & $\mathrm{~N}$ & 4.866 & 3.377 & 3.349 \\
\hline $\mathrm{N}$ & -8.158 & 5.113 & 0.341 & $\mathrm{H}$ & 0.678 & 12.465 & -4.894 & $\mathrm{C}$ & 3.784 & 3.202 & 4.216 \\
\hline C & -7.321 & 4.099 & -0.129 & $\mathrm{H}$ & 0.988 & 14.214 & -4.647 & $\mathrm{O}$ & 3.417 & 3.986 & 5.070 \\
\hline $\mathrm{O}$ & -6.914 & 3.985 & -1.268 & $\mathrm{~N}$ & 2.031 & 12.895 & -3.413 & $\mathrm{~N}$ & 3.236 & 1.949 & 3.958 \\
\hline C & -8.788 & 6.044 & -0.560 & C & 2.834 & 13.850 & -2.685 & $\mathrm{C}$ & 4.009 & 1.195 & 2.997 \\
\hline $\mathrm{H}$ & -9.882 & 5.967 & -0.449 & $\mathrm{H}$ & 2.941 & 14.784 & -3.258 & $\mathrm{H}$ & 4.348 & 0.249 & 3.448 \\
\hline $\mathrm{H}$ & -8.501 & 5.765 & -1.576 & $\mathrm{~N}$ & 2.395 & 14.137 & -1.333 & $\mathrm{~N}$ & 3.373 & 0.933 & 1.719 \\
\hline C & -8.625 & 7.104 & 2.959 & C & 3.333 & 13.736 & -0.362 & $\mathrm{C}$ & 4.112 & 1.443 & 0.653 \\
\hline $\mathrm{H}$ & -9.723 & 7.015 & 2.999 & $\mathrm{O}$ & 3.254 & 13.994 & 0.822 & $\mathrm{O}$ & 3.931 & 1.212 & -0.526 \\
\hline $\mathrm{H}$ & -8.248 & 7.434 & 3.930 & $\mathrm{~N}$ & 4.341 & 13.064 & -1.021 & $\mathrm{C}$ & 2.285 & 1.345 & 4.865 \\
\hline $\mathrm{N}$ & -8.289 & 8.131 & 1.989 & C & 4.193 & 13.100 & -2.466 & $\mathrm{H}$ & 2.729 & 0.425 & 5.281 \\
\hline C & -8.927 & 8.260 & 0.698 & $\mathrm{H}$ & 5.051 & 13.624 & -2.912 & $\mathrm{H}$ & 2.099 & 2.059 & 5.670 \\
\hline $\mathrm{H}$ & -10.010 & 8.095 & 0.798 & $\mathrm{~N}$ & 3.993 & 11.828 & -3.127 & $\mathrm{C}$ & 2.473 & -0.185 & 1.510 \\
\hline $\mathrm{N}$ & -8.396 & 7.435 & -0.376 & C & 2.758 & 11.737 & -3.749 & $\mathrm{H}$ & 2.910 & -1.090 & 1.964 \\
\hline C & -7.989 & 8.194 & -1.466 & $\mathrm{O}$ & 2.365 & 10.857 & -4.484 & $\mathrm{H}$ & 2.381 & -0.324 & 0.430 \\
\hline $\mathrm{O}$ & -7.682 & 7.789 & -2.568 & C & 5.605 & 12.761 & -0.356 & $\mathrm{H}$ & -2.104 & 12.671 & -0.790 \\
\hline $\mathrm{N}$ & -8.044 & 9.539 & -1.082 & & & & & & & & \\
\hline
\end{tabular}




\begin{tabular}{|c|c|c|c|c|c|c|c|c|c|c|c|}
\hline \multicolumn{12}{|c|}{ CB[10]-H+_N4 } \\
\hline $\mathrm{O}$ & -0.023 & -0.010 & 0.003 & $\mathrm{C}$ & -7.110 & 10.323 & -1.363 & $\mathrm{H}$ & 7.507 & 12.558 & 1.380 \\
\hline C & -0.019 & -0.027 & 1.218 & $\mathrm{H}$ & -7.908 & 10.923 & -1.828 & $\mathrm{H}$ & 6.227 & 11.944 & 2.479 \\
\hline $\mathrm{N}$ & 1.109 & -0.026 & 2.041 & $\mathrm{~N}$ & -6.539 & 11.036 & -0.247 & $\mathrm{C}$ & 7.272 & 10.973 & -2.017 \\
\hline C & 0.768 & -0.332 & 3.421 & $\mathrm{C}$ & -6.580 & 10.298 & 0.940 & $\mathrm{H}$ & 7.196 & 10.510 & -3.003 \\
\hline $\mathrm{H}$ & 1.147 & -1.331 & 3.690 & $\mathrm{O}$ & -6.250 & 10.706 & 2.036 & $\mathrm{H}$ & 8.113 & 11.682 & -2.001 \\
\hline $\mathrm{N}$ & 1.175 & 0.635 & 4.412 & $\mathrm{C}$ & -6.247 & 12.442 & -0.247 & $\mathrm{~N}$ & 7.511 & 9.924 & -1.066 \\
\hline $\mathrm{C}$ & 0.097 & 1.326 & 4.958 & $\mathrm{H}$ & -6.144 & 12.757 & 0.794 & $\mathrm{C}$ & 8.034 & 10.131 & 0.262 \\
\hline $\mathrm{O}$ & 0.145 & 2.116 & 5.881 & $\mathrm{H}$ & -7.077 & 12.987 & -0.722 & $\mathrm{H}$ & 8.867 & 10.850 & 0.238 \\
\hline $\mathrm{N}$ & -1.054 & 0.909 & 4.287 & $\mathrm{C}$ & -5.701 & 10.707 & -3.441 & $\mathrm{~N}$ & 7.065 & 10.517 & 1.272 \\
\hline C & -0.792 & -0.241 & 3.436 & $\mathrm{H}$ & -5.298 & 10.051 & -4.217 & $\mathrm{C}$ & 7.053 & 9.622 & 2.355 \\
\hline $\mathrm{H}$ & -1.274 & -1.138 & 3.857 & $\mathrm{H}$ & -6.538 & 11.295 & -3.852 & $\mathrm{O}$ & 6.489 & 9.807 & 3.414 \\
\hline $\mathrm{N}$ & -1.139 & -0.101 & 2.042 & $\mathrm{~N}$ & -5.008 & 12.815 & -0.927 & $\mathrm{~N}$ & 7.837 & 8.536 & 2.002 \\
\hline C & -2.458 & -0.352 & 1.509 & $\mathrm{C}$ & -4.890 & 12.882 & -2.374 & C & 8.469 & 8.697 & 0.712 \\
\hline $\mathrm{H}$ & -2.357 & -0.477 & 0.429 & $\mathrm{H}$ & -5.779 & 13.372 & -2.797 & $\mathrm{H}$ & 9.560 & 8.588 & 0.814 \\
\hline $\mathrm{H}$ & -2.847 & -1.282 & 1.956 & $\mathrm{~N}$ & -4.642 & 11.632 & -3.060 & $\mathrm{~N}$ & 7.984 & 7.844 & -0.361 \\
\hline C & -2.356 & 1.153 & 4.877 & $\mathrm{C}$ & -3.405 & 11.597 & -3.682 & $\mathrm{C}$ & 7.531 & 8.578 & -1.450 \\
\hline $\mathrm{H}$ & -2.753 & 0.207 & 5.281 & $\mathrm{O}$ & -2.977 & 10.742 & -4.428 & $\mathrm{O}$ & 7.241 & 8.156 & -2.551 \\
\hline $\mathrm{H}$ & -2.210 & 1.867 & 5.691 & $\mathrm{~N}$ & -2.726 & 12.780 & -3.334 & $\mathrm{C}$ & 8.447 & 6.475 & -0.544 \\
\hline $\mathrm{N}$ & -3.334 & 1.718 & 3.973 & $\mathrm{C}$ & -3.572 & 13.698 & -2.604 & $\mathrm{H}$ & 9.543 & 6.454 & -0.432 \\
\hline C & -3.949 & 2.937 & 4.247 & $\mathrm{H}$ & -3.728 & 14.623 & -3.180 & $\mathrm{H}$ & 8.175 & 6.180 & -1.560 \\
\hline $\mathrm{O}$ & -3.625 & 3.728 & 5.111 & $\mathrm{~N}$ & -3.140 & 14.013 & -1.257 & $\mathrm{C}$ & 8.226 & 7.529 & 2.973 \\
\hline $\mathrm{N}$ & -5.036 & 3.065 & 3.379 & $\mathrm{C}$ & -4.035 & 13.544 & -0.276 & $\mathrm{H}$ & 7.833 & 7.841 & 3.944 \\
\hline C & -5.289 & 1.842 & 2.641 & $\mathrm{O}$ & -3.954 & 13.796 & 0.909 & $\mathrm{H}$ & 9.327 & 7.498 & 3.012 \\
\hline $\mathrm{H}$ & -6.255 & 1.411 & 2.949 & $\mathrm{C}$ & -1.568 & 13.188 & -4.076 & $\mathrm{~N}$ & 7.712 & 6.205 & 2.711 \\
\hline $\mathrm{N}$ & -5.227 & 1.938 & 1.200 & $\mathrm{H}$ & -1.760 & 14.152 & -4.575 & $\mathrm{C}$ & 8.297 & 5.320 & 1.721 \\
\hline C & -4.172 & 1.205 & 0.662 & $\mathrm{H}$ & -1.364 & 12.421 & -4.828 & $\mathrm{H}$ & 9.397 & 5.361 & 1.779 \\
\hline $\mathrm{O}$ & -3.973 & 0.998 & -0.519 & $\mathrm{C}$ & -2.149 & 14.980 & -0.930 & $\mathrm{~N}$ & 7.864 & 5.514 & 0.357 \\
\hline $\mathrm{N}$ & -3.416 & 0.715 & 1.726 & $\mathrm{H}$ & -2.262 & 15.226 & 0.129 & $\mathrm{C}$ & 7.090 & 4.452 & -0.114 \\
\hline C & -4.067 & 0.935 & 3.004 & $\mathrm{H}$ & -2.255 & 15.885 & -1.542 & $\mathrm{O}$ & 6.696 & 4.313 & -1.255 \\
\hline $\mathrm{H}$ & -4.361 & -0.030 & 3.446 & $\mathrm{~N}$ & -0.752 & 14.511 & -1.125 & $\mathrm{~N}$ & 6.900 & 3.569 & 0.945 \\
\hline C & -6.344 & 2.351 & 0.381 & $\mathrm{C}$ & -0.110 & 14.476 & -2.432 & $\mathrm{C}$ & 7.712 & 3.918 & 2.098 \\
\hline $\mathrm{H}$ & -6.120 & 2.052 & -0.646 & $\mathrm{H}$ & -0.356 & 15.407 & -2.963 & $\mathrm{H}$ & 8.489 & 3.153 & 2.254 \\
\hline $\mathrm{H}$ & -7.254 & 1.837 & 0.729 & $\mathrm{~N}$ & -0.346 & 13.314 & -3.266 & $\mathrm{~N}$ & 7.006 & 4.164 & 3.335 \\
\hline C & -6.074 & 4.033 & 3.660 & $\mathrm{C}$ & 0.866 & 12.857 & -3.812 & $\mathrm{C}$ & 7.062 & 5.495 & 3.727 \\
\hline $\mathrm{H}$ & -5.718 & 4.665 & 4.477 & $\mathrm{O}$ & 1.014 & 12.100 & -4.736 & $\mathrm{O}$ & 6.662 & 5.960 & 4.776 \\
\hline $\mathrm{H}$ & -6.988 & 3.501 & 3.976 & $\mathrm{~N}$ & 1.907 & 13.481 & -3.085 & $\mathrm{C}$ & 6.613 & 3.119 & 4.258 \\
\hline $\mathrm{N}$ & -6.594 & 3.779 & 0.368 & $\mathrm{C}$ & 1.398 & 14.361 & -2.119 & $\mathrm{H}$ & 6.381 & 3.598 & 5.212 \\
\hline C & -7.249 & 4.481 & 1.448 & $\mathrm{H}$ & 1.909 & 15.327 & -2.066 & $\mathrm{H}$ & 7.461 & 2.427 & 4.387 \\
\hline $\mathrm{H}$ & -8.088 & 3.880 & 1.832 & $\mathrm{~N}$ & 1.414 & 13.797 & -0.684 & $\mathrm{C}$ & 6.463 & 2.208 & 0.684 \\
\hline $\mathrm{N}$ & -6.404 & 4.908 & 2.550 & $\mathrm{C}$ & 0.038 & 14.200 & -0.076 & $\mathrm{H}$ & 6.161 & 2.162 & -0.364 \\
\hline C & -6.451 & 6.287 & 2.739 & $\mathrm{O}$ & -0.131 & 14.208 & 1.107 & $\mathrm{H}$ & 7.312 & 1.524 & 0.855 \\
\hline $\mathrm{O}$ & -6.000 & 6.904 & 3.684 & $\mathrm{C}$ & 2.608 & 14.214 & 0.184 & $\mathrm{~N}$ & 5.337 & 1.772 & 1.479 \\
\hline $\mathrm{N}$ & -7.156 & 6.836 & 1.667 & $\mathrm{H}$ & 2.308 & 14.056 & 1.224 & $\mathrm{C}$ & 5.470 & 1.332 & 2.853 \\
\hline C & -7.705 & 5.826 & 0.792 & $\mathrm{H}$ & 2.754 & 15.283 & -0.015 & $\mathrm{H}$ & 6.380 & 0.720 & 2.965 \\
\hline $\mathrm{H}$ & -8.800 & 5.931 & 0.735 & C & 3.319 & 13.396 & -3.449 & $\mathrm{~N}$ & 5.443 & 2.366 & 3.863 \\
\hline $\mathrm{N}$ & -7.140 & 5.760 & -0.543 & $\mathrm{H}$ & 3.385 & 12.757 & -4.333 & $\mathrm{C}$ & 4.347 & 2.246 & 4.718 \\
\hline C & -6.599 & 4.501 & -0.820 & $\mathrm{H}$ & 3.670 & 14.409 & -3.698 & $\mathrm{O}$ & 4.164 & 2.878 & 5.740 \\
\hline $\mathrm{O}$ & -6.240 & 4.102 & -1.910 & $\mathrm{~N}$ & 4.154 & 12.810 & -2.427 & $\mathrm{~N}$ & 3.530 & 1.240 & 4.210 \\
\hline C & -7.591 & 6.607 & -1.624 & $\mathrm{C}$ & 4.603 & 13.534 & -1.257 & $\mathrm{C}$ & 4.153 & 0.528 & 3.112 \\
\hline $\mathrm{H}$ & -8.693 & 6.643 & -1.629 & $\mathrm{H}$ & 4.785 & 14.594 & -1.492 & $\mathrm{H}$ & 4.334 & -0.520 & 3.398 \\
\hline $\mathrm{H}$ & -7.234 & 6.157 & -2.553 & $\mathrm{~N}$ & 3.740 & 13.415 & -0.088 & $\mathrm{~N}$ & 3.465 & 0.578 & 1.839 \\
\hline C & -7.622 & 8.200 & 1.703 & $\mathrm{C}$ & 4.385 & 12.752 & 0.994 & $\mathrm{C}$ & 4.207 & 1.234 & 0.861 \\
\hline $\mathrm{H}$ & -8.724 & 8.205 & 1.662 & $\mathrm{O}$ & 3.906 & 12.641 & 2.101 & $\mathrm{O}$ & 3.943 & 1.294 & -0.324 \\
\hline $\mathrm{H}$ & -7.287 & 8.637 & 2.646 & $\mathrm{~N}$ & 5.615 & 12.342 & 0.543 & $\mathrm{C}$ & 2.481 & 0.660 & 5.028 \\
\hline $\mathrm{N}$ & -7.110 & 9.049 & 0.636 & $\mathrm{C}$ & 5.901 & 12.771 & -0.816 & $\mathrm{H}$ & 2.764 & -0.371 & 5.296 \\
\hline C & -7.631 & 8.995 & -0.721 & $\mathrm{H}$ & 6.796 & 13.411 & -0.816 & $\mathrm{H}$ & 2.407 & 1.269 & 5.932 \\
\hline $\mathrm{H}$ & -8.730 & 8.927 & -0.699 & $\mathrm{~N}$ & 6.036 & 11.727 & -1.809 & $\mathrm{C}$ & 2.407 & -0.341 & 1.476 \\
\hline $\mathrm{N}$ & -7.091 & 7.967 & -1.580 & $\mathrm{C}$ & 5.080 & 11.808 & -2.805 & $\mathrm{H}$ & 2.700 & -1.359 & 1.786 \\
\hline C & -6.275 & 8.477 & -2.578 & $\mathrm{O}$ & 5.036 & 11.183 & -3.841 & $\mathrm{H}$ & 2.301 & -0.306 & 0.389 \\
\hline $\mathrm{O}$ & -5.770 & 7.859 & -3.493 & $\mathrm{C}$ & 6.645 & 11.877 & 1.471 & $\mathrm{H}$ & 1.432 & 12.769 & -0.740 \\
\hline $\mathrm{N}$ & -6.174 & 9.861 & -2.373 & & & & & & & & \\
\hline
\end{tabular}




\begin{tabular}{|c|c|c|c|c|c|c|c|c|c|c|c|}
\hline \multicolumn{12}{|c|}{ CB[10]A } \\
\hline C & -0.010 & -0.012 & 0.020 & $\mathrm{~N}$ & 1.395 & -5.504 & -11.910 & $\mathrm{C}$ & -1.468 & -7.467 & 3.166 \\
\hline $\mathrm{N}$ & -0.014 & 0.003 & 1.483 & C & 0.558 & -6.092 & -10.863 & $\mathrm{H}$ & -1.895 & -7.380 & 4.175 \\
\hline C & 1.383 & 0.017 & 1.880 & $\mathrm{~N}$ & 0.838 & -7.523 & -10.955 & $\mathrm{~N}$ & -0.021 & -7.524 & 3.268 \\
\hline $\mathrm{H}$ & 1.462 & 0.415 & 2.902 & C & 2.113 & -7.722 & -11.667 & $\mathrm{C}$ & 0.439 & -8.145 & 2.025 \\
\hline $\mathrm{N}$ & 2.144 & -1.240 & 1.775 & $\mathrm{H}$ & 1.938 & -8.293 & -12.590 & $\mathrm{C}$ & 0.686 & -6.360 & 3.776 \\
\hline C & 3.208 & -1.075 & 0.788 & $\mathrm{~N}$ & 3.215 & -8.327 & -10.939 & $\mathrm{H}$ & 1.755 & -6.602 & 3.762 \\
\hline $\mathrm{N}$ & 3.370 & 0.376 & 0.689 & C & 3.728 & -7.280 & -10.055 & $\mathrm{H}$ & 0.387 & -6.258 & 4.833 \\
\hline C & 2.035 & 0.932 & 0.822 & $\mathrm{C}$ & -0.236 & -8.459 & -11.261 & $\mathrm{C}$ & -2.640 & -5.278 & 2.933 \\
\hline $\mathrm{H}$ & 2.113 & 1.979 & 1.145 & $\mathrm{H}$ & -0.072 & -8.886 & -12.264 & $\mathrm{H}$ & -3.558 & -4.995 & 2.405 \\
\hline $\mathrm{N}$ & 1.127 & 0.834 & -0.335 & $\mathrm{H}$ & -1.187 & -7.914 & -11.290 & $\mathrm{H}$ & -2.924 & -5.537 & 3.967 \\
\hline C & 0.917 & 2.055 & -1.102 & $\mathrm{C}$ & 3.047 & -9.670 & -10.412 & $\mathrm{~N}$ & -1.819 & -4.084 & 3.027 \\
\hline $\mathrm{H}$ & -0.134 & 2.111 & -1.407 & $\mathrm{H}$ & 3.976 & -9.929 & -9.890 & C & -0.523 & -4.180 & 3.675 \\
\hline $\mathrm{H}$ & 1.119 & 2.930 & -0.461 & $\mathrm{H}$ & 2.967 & -10.336 & -11.288 & $\mathrm{H}$ & -0.670 & -4.421 & 4.737 \\
\hline $\mathrm{C}$ & 4.252 & 0.921 & -0.329 & $\mathrm{~N}$ & 1.919 & -9.905 & -9.521 & $\mathrm{~N}$ & 0.477 & -5.092 & 3.090 \\
\hline $\mathrm{H}$ & 4.480 & 1.953 & -0.016 & C & 0.705 & -10.476 & -10.131 & C & 1.621 & -4.312 & 2.625 \\
\hline $\mathrm{H}$ & 5.187 & 0.351 & -0.280 & $\mathrm{H}$ & 0.964 & -10.984 & -11.071 & $\mathrm{~N}$ & 1.506 & -3.051 & 3.357 \\
\hline $\mathrm{N}$ & 3.770 & 0.927 & -1.704 & $\mathrm{~N}$ & -0.420 & -9.589 & -10.367 & C & 0.082 & -2.779 & 3.448 \\
\hline C & 4.593 & 0.358 & -2.769 & C & -1.033 & -9.369 & -9.057 & $\mathrm{H}$ & -0.099 & -2.088 & 4.284 \\
\hline $\mathrm{N}$ & 4.853 & 1.493 & -3.656 & $\mathrm{~N}$ & -0.892 & -10.658 & -8.384 & $\mathrm{~N}$ & -0.607 & -2.292 & 2.239 \\
\hline C & 3.634 & 2.283 & -3.649 & C & 0.167 & -11.437 & -9.050 & C & -1.599 & -3.280 & 1.824 \\
\hline $\mathrm{H}$ & 3.871 & 3.311 & -3.958 & $\mathrm{H}$ & -0.257 & -12.362 & -9.466 & C & 2.400 & -1.956 & 3.016 \\
\hline $\mathrm{N}$ & 2.482 & 1.784 & -4.421 & $\mathrm{~N}$ & 1.358 & -11.763 & -8.286 & $\mathrm{H}$ & 2.355 & -1.250 & 3.862 \\
\hline $\mathrm{C}$ & 1.388 & 1.479 & -3.503 & C & 2.132 & -10.523 & -8.215 & $\mathrm{H}$ & 3.415 & -2.369 & 2.990 \\
\hline $\mathrm{N}$ & 1.719 & 2.242 & -2.299 & C & 1.216 & -12.573 & -7.088 & C & -0.929 & -0.872 & 2.196 \\
\hline C & 3.165 & 2.183 & -2.183 & $\mathrm{H}$ & 2.217 & -12.683 & -6.655 & $\mathrm{H}$ & -0.991 & -0.479 & 3.224 \\
\hline $\mathrm{H}$ & 3.509 & 3.022 & -1.561 & $\mathrm{H}$ & 0.895 & -13.571 & -7.429 & $\mathrm{H}$ & -1.917 & -0.743 & 1.738 \\
\hline C & 2.211 & 2.448 & -5.689 & C & -2.077 & -11.396 & -7.965 & $\mathrm{H}$ & 1.330 & 0.394 & -3.300 \\
\hline $\mathrm{H}$ & 1.126 & 2.546 & -5.818 & $\mathrm{H}$ & -2.965 & -10.778 & -8.141 & $\mathrm{H}$ & 0.420 & 1.804 & -3.910 \\
\hline $\mathrm{H}$ & 2.632 & 3.467 & -5.667 & $\mathrm{H}$ & -2.181 & -12.303 & -8.583 & $\mathrm{H}$ & 1.967 & -0.155 & -6.640 \\
\hline C & 5.523 & 1.258 & -4.923 & $\mathrm{~N}$ & -2.137 & -11.842 & -6.583 & $\mathrm{H}$ & 1.061 & 0.873 & -7.784 \\
\hline $\mathrm{H}$ & 6.398 & 0.633 & -4.712 & C & -1.057 & -12.664 & -6.070 & $\mathrm{H}$ & 1.773 & -2.484 & -9.151 \\
\hline $\mathrm{H}$ & 5.895 & 2.241 & -5.260 & $\mathrm{H}$ & -1.052 & -13.624 & -6.605 & $\mathrm{H}$ & 0.710 & -2.064 & -10.523 \\
\hline $\mathrm{N}$ & 2.727 & 1.826 & -6.896 & $\mathrm{~N}$ & 0.303 & -12.094 & -6.060 & $\mathrm{H}$ & 0.814 & -5.698 & -9.863 \\
\hline C & 4.151 & 1.557 & -6.984 & C & 0.757 & -11.968 & -4.678 & $\mathrm{H}$ & -0.502 & -5.877 & -11.055 \\
\hline $\mathrm{H}$ & 4.697 & 2.512 & -6.985 & $\mathrm{~N}$ & -0.103 & -12.895 & -3.941 & $\mathrm{H}$ & -2.090 & -9.090 & -9.170 \\
\hline $\mathrm{N}$ & 4.746 & 0.644 & -5.992 & C & -1.408 & -12.804 & -4.574 & $\mathrm{H}$ & -0.523 & -8.568 & -8.493 \\
\hline C & 5.255 & -0.541 & -6.679 & $\mathrm{H}$ & -1.980 & -13.715 & -4.348 & $\mathrm{H}$ & -3.459 & -10.500 & -5.622 \\
\hline $\mathrm{N}$ & 5.394 & -0.107 & -8.069 & $\mathrm{~N}$ & -2.231 & -11.614 & -4.294 & $\mathrm{H}$ & -1.748 & -9.993 & -5.582 \\
\hline C & 4.276 & 0.786 & -8.315 & C & -2.426 & -10.864 & -5.533 & $\mathrm{H}$ & -4.076 & -9.552 & -1.744 \\
\hline $\mathrm{H}$ & 4.515 & 1.433 & -9.170 & C & -0.033 & -12.918 & -2.490 & $\mathrm{H}$ & -2.364 & -9.442 & -2.240 \\
\hline $\mathrm{N}$ & 2.941 & 0.187 & -8.498 & $\mathrm{H}$ & -0.499 & -13.867 & -2.176 & $\mathrm{H}$ & -3.729 & -6.611 & 0.981 \\
\hline C & 2.066 & 0.627 & -7.414 & $\mathrm{H}$ & 1.028 & -12.971 & -2.222 & $\mathrm{H}$ & -2.171 & -7.112 & 0.268 \\
\hline C & 2.437 & 0.120 & -9.863 & C & -3.339 & -11.792 & -3.366 & $\mathrm{H}$ & -2.536 & -2.800 & 1.507 \\
\hline $\mathrm{H}$ & 2.932 & 0.893 & -10.474 & $\mathrm{H}$ & -4.199 & -11.211 & -3.719 & $\mathrm{H}$ & -1.224 & -3.893 & 0.984 \\
\hline $\mathrm{H}$ & 1.364 & 0.345 & -9.860 & $\mathrm{H}$ & -3.643 & -12.852 & -3.356 & $\mathrm{H}$ & 0.115 & -1.034 & -0.380 \\
\hline C & 5.732 & -1.091 & -9.083 & $\mathrm{~N}$ & -3.120 & -11.423 & -1.977 & $\mathrm{H}$ & -0.952 & 0.398 & -0.370 \\
\hline $\mathrm{H}$ & 6.083 & -0.520 & -9.959 & $\mathrm{C}$ & -2.017 & -12.039 & -1.262 & $\mathrm{H}$ & 1.780 & -9.865 & -7.401 \\
\hline $\mathrm{H}$ & 6.587 & -1.662 & -8.703 & $\mathrm{H}$ & -2.206 & -13.118 & -1.169 & $\mathrm{H}$ & 3.195 & -10.743 & -8.044 \\
\hline $\mathrm{N}$ & 4.688 & -2.018 & -9.497 & $\mathrm{~N}$ & -0.652 & -11.814 & -1.769 & $\mathrm{H}$ & 3.146 & -7.212 & -9.118 \\
\hline C & 3.946 & -1.676 & -10.723 & C & 0.113 & -11.068 & -0.772 & $\mathrm{H}$ & 4.777 & -7.478 & -9.794 \\
\hline $\mathrm{H}$ & 4.545 & -0.994 & -11.343 & $\mathrm{~N}$ & -0.628 & -11.287 & 0.471 & $\mathrm{H}$ & 4.218 & -3.971 & -8.804 \\
\hline $\mathrm{N}$ & 2.607 & -1.132 & -10.581 & C & -2.030 & -11.301 & 0.094 & $\mathrm{H}$ & 5.950 & -3.685 & -9.124 \\
\hline C & 1.751 & -2.267 & -10.235 & $\mathrm{H}$ & -2.604 & -11.829 & 0.869 & $\mathrm{H}$ & 4.553 & -1.389 & -6.582 \\
\hline $\mathrm{N}$ & 2.311 & -3.375 & -11.005 & $\mathrm{~N}$ & -2.675 & -10.012 & -0.215 & $\mathrm{H}$ & 6.228 & -0.853 & -6.274 \\
\hline C & 3.694 & -3.042 & -11.394 & $\mathrm{C}$ & -3.083 & -10.006 & -1.618 & $\mathrm{H}$ & 4.062 & -0.458 & -3.291 \\
\hline $\mathrm{H}$ & 3.774 & -3.009 & -12.490 & C & -3.556 & -9.462 & 0.805 & $\mathrm{H}$ & 5.537 & -0.044 & -2.375 \\
\hline $\mathrm{N}$ & 4.767 & -3.866 & -10.866 & $\mathrm{H}$ & -3.928 & -10.277 & 1.447 & $\mathrm{H}$ & 4.144 & -1.543 & 1.125 \\
\hline C & 4.933 & -3.458 & -9.471 & $\mathrm{H}$ & -4.428 & -9.008 & 0.318 & $\mathrm{H}$ & 2.927 & -1.525 & -0.181 \\
\hline C & 4.778 & -5.282 & -11.192 & C & -0.237 & -10.553 & 1.663 & $\mathrm{H}$ & 2.571 & -4.810 & 2.866 \\
\hline $\mathrm{H}$ & 5.652 & -5.719 & -10.694 & $\mathrm{H}$ & 0.850 & -10.656 & 1.760 & $\mathrm{H}$ & 1.581 & -4.157 & 1.532 \\
\hline $\mathrm{H}$ & 4.954 & -5.345 & -12.279 & $\mathrm{H}$ & -0.694 & -11.086 & 2.513 & $\mathrm{H}$ & 1.422 & -8.613 & 2.171 \\
\hline C & 1.497 & -4.057 & -12.002 & $\mathrm{~N}$ & -0.588 & -9.141 & 1.731 & $\mathrm{H}$ & 0.526 & -7.409 & 1.205 \\
\hline $\mathrm{H}$ & 0.476 & -3.660 & -11.963 & $\mathrm{C}$ & -1.818 & -8.799 & 2.470 & $\mathrm{H}$ & 1.138 & -11.453 & -0.682 \\
\hline $\mathrm{H}$ & 1.895 & -3.842 & -13.008 & $\mathrm{H}$ & -2.066 & -9.605 & 3.174 & $\mathrm{H}$ & 0.168 & -9.996 & -1.034 \\
\hline $\mathrm{N}$ & 3.597 & -6.060 & -10.847 & $\mathrm{~N}$ & -3.002 & -8.462 & 1.701 & $\mathrm{H}$ & 1.812 & -12.258 & -4.574 \\
\hline C & 2.617 & -6.287 & -11.925 & C & -2.773 & -7.108 & 1.195 & $\mathrm{H}$ & 0.647 & -10.930 & -4.315 \\
\hline $\mathrm{H}$ & 3.106 & -6.170 & -12.903 & $\mathrm{~N}$ & -2.059 & -6.445 & 2.284 & & & & \\
\hline
\end{tabular}




\begin{tabular}{|c|c|c|c|c|c|c|c|c|c|c|c|}
\hline \multicolumn{12}{|c|}{ CB[10]A-H+_N2 } \\
\hline $\mathrm{C}$ & -0.139 & 0.118 & -0.324 & $\mathrm{~N}$ & 1.336 & -5.271 & -11.788 & C & -1.590 & -7.614 & 3.176 \\
\hline $\mathrm{N}$ & -0.061 & -0.239 & 1.106 & $\mathrm{C}$ & 0.498 & -5.839 & -10.732 & $\mathrm{H}$ & -2.032 & -7.467 & 4.171 \\
\hline C & 1.281 & -0.259 & 1.476 & $\mathrm{~N}$ & 0.762 & -7.275 & -10.807 & $\mathrm{~N}$ & -0.148 & -7.712 & 3.303 \\
\hline $\mathrm{H}$ & 1.457 & -0.147 & 2.546 & $\mathrm{C}$ & 2.033 & -7.493 & -11.527 & $\mathrm{C}$ & 0.320 & -8.426 & 2.111 \\
\hline $\mathrm{N}$ & 2.055 & -1.646 & 1.080 & $\mathrm{H}$ & 1.845 & -8.070 & -12.443 & C & 0.585 & -6.562 & 3.767 \\
\hline C & 3.070 & -1.239 & 0.050 & $\mathrm{~N}$ & 3.133 & -8.100 & -10.801 & $\mathrm{H}$ & 1.640 & -6.848 & 3.843 \\
\hline $\mathrm{N}$ & 3.308 & 0.149 & 0.363 & C & 3.662 & -7.051 & -9.931 & $\mathrm{H}$ & 0.228 & -6.343 & 4.785 \\
\hline C & 1.994 & 0.749 & 0.575 & C & -0.324 & -8.197 & -11.122 & $\mathrm{C}$ & -2.627 & -5.375 & 2.794 \\
\hline $\mathrm{H}$ & 2.141 & 1.719 & 1.071 & $\mathrm{H}$ & -0.177 & -8.602 & -12.137 & $\mathrm{H}$ & -3.554 & -5.090 & 2.283 \\
\hline $\mathrm{N}$ & 1.084 & 0.871 & -0.566 & $\mathrm{H}$ & -1.271 & -7.645 & -11.125 & $\mathrm{H}$ & -2.868 & -5.507 & 3.860 \\
\hline C & 1.006 & 2.197 & -1.220 & C & 2.969 & -9.444 & -10.275 & $\mathrm{~N}$ & -1.738 & -4.210 & 2.728 \\
\hline $\mathrm{H}$ & -0.036 & 2.368 & -1.510 & $\mathrm{H}$ & 3.893 & -9.695 & -9.742 & $\mathrm{C}$ & -0.451 & -4.293 & 3.401 \\
\hline $\mathrm{H}$ & 1.273 & 2.966 & -0.478 & $\mathrm{H}$ & 2.905 & -10.111 & -11.151 & $\mathrm{H}$ & -0.622 & -4.364 & 4.484 \\
\hline C & 4.257 & 0.861 & -0.512 & $\mathrm{~N}$ & 1.831 & -9.683 & -9.396 & $\mathrm{~N}$ & 0.496 & -5.328 & 2.975 \\
\hline $\mathrm{H}$ & 4.430 & 1.833 & -0.028 & C & 0.621 & -10.237 & -10.035 & C & 1.670 & -4.743 & 2.375 \\
\hline $\mathrm{H}$ & 5.199 & 0.302 & -0.470 & $\mathrm{H}$ & 0.890 & -10.714 & -10.988 & $\mathrm{~N}$ & 1.628 & -3.338 & 2.834 \\
\hline $\mathrm{N}$ & 3.838 & 1.028 & -1.879 & $\mathrm{~N}$ & -0.502 & -9.345 & -10.251 & $\mathrm{C}$ & 0.231 & -2.973 & 2.974 \\
\hline C & 4.679 & 0.537 & -2.978 & C & -1.128 & -9.167 & -8.942 & $\mathrm{H}$ & 0.117 & -2.174 & 3.714 \\
\hline $\mathrm{N}$ & 4.965 & 1.736 & -3.754 & $\mathrm{~N}$ & -0.992 & -10.477 & -8.307 & $\mathrm{~N}$ & -0.461 & -2.583 & 1.695 \\
\hline C & 3.753 & 2.539 & -3.708 & C & 0.075 & -11.233 & -8.992 & C & -1.441 & -3.660 & 1.415 \\
\hline $\mathrm{H}$ & 4.012 & 3.581 & -3.937 & $\mathrm{H}$ & -0.344 & -12.143 & -9.443 & $\mathrm{C}$ & 2.566 & -2.402 & 2.325 \\
\hline $\mathrm{N}$ & 2.601 & 2.116 & -4.519 & $\mathrm{~N}$ & 1.258 & -11.583 & -8.228 & $\mathrm{H}$ & 2.812 & -1.629 & 3.060 \\
\hline C & 1.473 & 1.801 & -3.656 & C & 2.033 & -10.348 & -8.110 & $\mathrm{H}$ & 3.487 & -2.917 & 2.043 \\
\hline $\mathrm{N}$ & 1.826 & 2.423 & -2.376 & $\mathrm{C}$ & 1.111 & -12.443 & -7.068 & $\mathrm{C}$ & -0.985 & -1.207 & 1.695 \\
\hline C & 3.266 & 2.339 & -2.258 & $\mathrm{H}$ & 2.108 & -12.565 & -6.629 & $\mathrm{H}$ & -1.216 & -0.872 & 2.716 \\
\hline $\mathrm{H}$ & 3.623 & 3.115 & -1.568 & $\mathrm{H}$ & 0.801 & -13.428 & -7.454 & $\mathrm{H}$ & -1.911 & -1.166 & 1.119 \\
\hline C & 2.384 & 2.809 & -5.792 & $\mathrm{C}$ & -2.181 & -11.234 & -7.936 & $\mathrm{H}$ & 1.333 & 0.708 & -3.552 \\
\hline $\mathrm{H}$ & 1.309 & 2.977 & -5.921 & $\mathrm{H}$ & -3.067 & -10.609 & -8.092 & $\mathrm{H}$ & 0.536 & 2.228 & -4.041 \\
\hline $\mathrm{H}$ & 2.868 & 3.798 & -5.744 & $\mathrm{H}$ & -2.279 & -12.112 & -8.595 & $\mathrm{H}$ & 2.032 & 0.225 & -6.725 \\
\hline C & 5.640 & 1.569 & -5.039 & $\mathrm{~N}$ & -2.251 & -11.741 & -6.576 & $\mathrm{H}$ & 1.172 & 1.274 & -7.885 \\
\hline $\mathrm{H}$ & 6.538 & 0.969 & -4.848 & C & -1.176 & -12.586 & -6.088 & $\mathrm{H}$ & 1.789 & -2.158 & -9.126 \\
\hline $\mathrm{H}$ & 5.976 & 2.574 & -5.336 & $\mathrm{H}$ & -1.162 & -13.518 & -6.669 & $\mathrm{H}$ & 0.723 & -1.767 & -10.504 \\
\hline $\mathrm{N}$ & 2.868 & 2.172 & -6.996 & $\mathrm{~N}$ & 0.182 & -12.015 & -6.028 & $\mathrm{H}$ & 0.762 & -5.439 & -9.736 \\
\hline C & 4.284 & 1.878 & -7.108 & $\mathrm{C}$ & 0.619 & -11.967 & -4.635 & $\mathrm{H}$ & -0.561 & -5.615 & -10.921 \\
\hline $\mathrm{H}$ & 4.847 & 2.822 & -7.131 & $\mathrm{~N}$ & -0.260 & -12.920 & -3.957 & $\mathrm{H}$ & -2.184 & -8.885 & -9.058 \\
\hline $\mathrm{N}$ & 4.871 & 0.967 & -6.109 & $\mathrm{C}$ & -1.551 & -12.800 & -4.607 & $\mathrm{H}$ & -0.624 & -8.384 & -8.347 \\
\hline C & 5.355 & -0.238 & -6.783 & $\mathrm{H}$ & -2.127 & -13.720 & -4.435 & $\mathrm{H}$ & -3.590 & -10.449 & -5.575 \\
\hline $\mathrm{N}$ & 5.481 & 0.173 & -8.178 & $\mathrm{~N}$ & -2.379 & -11.623 & -4.282 & $\mathrm{H}$ & -1.880 & -9.942 & -5.484 \\
\hline C & 4.375 & 1.082 & -8.426 & C & -2.558 & -10.815 & -5.487 & $\mathrm{H}$ & -4.241 & -9.656 & -1.696 \\
\hline $\mathrm{H}$ & 4.618 & 1.710 & -9.295 & C & -0.214 & -13.019 & -2.510 & $\mathrm{H}$ & -2.524 & -9.542 & -2.174 \\
\hline $\mathrm{N}$ & 3.026 & 0.512 & -8.583 & $\mathrm{H}$ & -0.699 & -13.975 & -2.251 & $\mathrm{H}$ & -3.790 & -6.764 & 0.925 \\
\hline $\mathrm{C}$ & 2.166 & 0.994 & -7.510 & $\mathrm{H}$ & 0.841 & -13.101 & -2.226 & $\mathrm{H}$ & -2.248 & -7.361 & 0.249 \\
\hline C & 2.508 & 0.402 & -9.945 & $\mathrm{C}$ & -3.498 & -11.844 & -3.379 & $\mathrm{H}$ & -2.343 & -3.263 & 0.939 \\
\hline $\mathrm{H}$ & 3.021 & 1.138 & -10.585 & $\mathrm{H}$ & -4.358 & -11.256 & -3.719 & $\mathrm{H}$ & -0.988 & -4.404 & 0.740 \\
\hline $\mathrm{H}$ & 1.443 & 0.659 & -9.942 & $\mathrm{H}$ & -3.794 & -12.905 & -3.410 & $\mathrm{H}$ & -0.204 & -0.786 & -0.958 \\
\hline $\mathrm{C}$ & 5.785 & -0.844 & -9.176 & $\mathrm{~N}$ & -3.294 & -11.524 & -1.974 & $\mathrm{H}$ & -1.036 & 0.722 & -0.510 \\
\hline $\mathrm{H}$ & 6.121 & -0.299 & -10.073 & $\mathrm{C}$ & -2.207 & -12.172 & -1.263 & $\mathrm{H}$ & 1.675 & -9.716 & -7.277 \\
\hline $\mathrm{H}$ & 6.643 & -1.413 & -8.800 & $\mathrm{H}$ & -2.408 & -13.251 & -1.209 & $\mathrm{H}$ & 3.094 & -10.575 & -7.937 \\
\hline $\mathrm{N}$ & 4.717 & -1.764 & -9.533 & $\mathrm{~N}$ & -0.831 & -11.943 & -1.739 & $\mathrm{H}$ & 3.087 & -6.966 & -8.991 \\
\hline C & 3.961 & -1.454 & -10.761 & $\mathrm{C}$ & -0.068 & -11.257 & -0.701 & $\mathrm{H}$ & 4.710 & -7.258 & -9.674 \\
\hline $\mathrm{H}$ & 4.564 & -0.810 & -11.416 & $\mathrm{~N}$ & -0.843 & -11.489 & 0.519 & $\mathrm{H}$ & 4.218 & -3.680 & -8.759 \\
\hline $\mathrm{N}$ & 2.638 & -0.878 & -10.613 & $\mathrm{C}$ & -2.237 & -11.478 & 0.114 & $\mathrm{H}$ & 5.952 & -3.442 & -9.115 \\
\hline C & 1.761 & -1.982 & -10.218 & $\mathrm{H}$ & -2.833 & -12.021 & 0.861 & $\mathrm{H}$ & 4.643 & -1.075 & -6.662 \\
\hline $\mathrm{N}$ & 2.289 & -3.130 & -10.949 & $\mathrm{~N}$ & -2.854 & -10.170 & -0.169 & $\mathrm{H}$ & 6.330 & -0.556 & -6.386 \\
\hline C & 3.672 & -2.841 & -11.372 & $\mathrm{C}$ & -3.252 & -10.120 & -1.576 & $\mathrm{H}$ & 4.142 & -0.224 & -3.572 \\
\hline $\mathrm{H}$ & 3.736 & -2.852 & -12.470 & C & -3.720 & -9.616 & 0.855 & $\mathrm{H}$ & 5.609 & 0.090 & -2.600 \\
\hline $\mathrm{N}$ & 4.739 & -3.662 & -10.830 & $\mathrm{H}$ & -4.082 & -10.420 & 1.515 & $\mathrm{H}$ & 3.982 & -1.835 & 0.144 \\
\hline C & 4.934 & -3.207 & -9.456 & $\mathrm{H}$ & -4.600 & -9.163 & 0.383 & $\mathrm{H}$ & 2.623 & -1.400 & -0.943 \\
\hline C & 4.732 & -5.089 & -11.109 & C & -0.470 & -10.799 & 1.736 & $\mathrm{H}$ & 2.591 & -5.226 & 2.727 \\
\hline $\mathrm{H}$ & 5.601 & -5.520 & -10.600 & $\mathrm{H}$ & 0.605 & -10.955 & 1.881 & $\mathrm{H}$ & 1.656 & -4.808 & 1.268 \\
\hline $\mathrm{H}$ & 4.904 & -5.189 & -12.193 & $\mathrm{H}$ & -0.991 & -11.315 & 2.558 & $\mathrm{H}$ & 1.266 & -8.943 & 2.324 \\
\hline C & 1.446 & -3.830 & -11.914 & $\mathrm{~N}$ & -0.752 & -9.365 & 1.821 & $\mathrm{H}$ & 0.492 & -7.733 & 1.265 \\
\hline $\mathrm{H}$ & 0.430 & -3.422 & -11.861 & $\mathrm{C}$ & -1.978 & -8.957 & 2.526 & $\mathrm{H}$ & 0.942 & -11.678 & -0.599 \\
\hline $\mathrm{H}$ & 1.823 & -3.639 & -12.932 & $\mathrm{H}$ & -2.266 & -9.726 & 3.256 & $\mathrm{H}$ & 0.029 & -10.178 & -0.924 \\
\hline $\mathrm{N}$ & 3.539 & -5.836 & -10.733 & $\mathrm{~N}$ & -3.144 & -8.604 & 1.733 & $\mathrm{H}$ & 1.669 & -12.273 & -4.532 \\
\hline C & 2.549 & -6.066 & -11.803 & C & -2.857 & -7.291 & 1.168 & $\mathrm{H}$ & 0.515 & -10.947 & -4.221 \\
\hline $\mathrm{H}$ & 3.032 & -5.966 & -12.785 & $\mathrm{~N}$ & -2.119 & -6.608 & 2.234 & $\mathrm{H}$ & 1.305 & -2.241 & 0.694 \\
\hline
\end{tabular}




\begin{tabular}{|c|c|c|c|c|c|c|c|c|c|c|c|}
\hline \multicolumn{12}{|c|}{ CB[10]A-H+_N4 } \\
\hline $\mathrm{C}$ & 0.110 & 0.239 & 0.077 & $\mathrm{~N}$ & 1.250 & -5.434 & -11.972 & C & -1.480 & -7.370 & 2.921 \\
\hline $\mathrm{N}$ & 0.013 & 0.149 & 1.529 & $\mathrm{C}$ & 0.425 & -6.074 & -10.947 & $\mathrm{H}$ & -1.940 & -7.278 & 3.915 \\
\hline $\mathrm{C}$ & 1.362 & 0.199 & 2.045 & $\mathrm{~N}$ & 0.708 & -7.497 & -11.108 & $\mathrm{~N}$ & -0.039 & -7.430 & 3.062 \\
\hline $\mathrm{H}$ & 1.339 & 0.573 & 3.077 & $\mathrm{C}$ & 1.974 & -7.662 & -11.843 & $\mathrm{C}$ & 0.459 & -8.058 & 1.836 \\
\hline $\mathrm{N}$ & 2.201 & -1.006 & 2.009 & $\mathrm{H}$ & 1.789 & -8.195 & -12.786 & C & 0.658 & -6.301 & 3.629 \\
\hline C & 3.143 & -0.961 & 0.944 & $\mathrm{~N}$ & 3.087 & -8.294 & -11.154 & $\mathrm{H}$ & 1.725 & -6.548 & 3.643 \\
\hline $\mathrm{N}$ & 3.467 & 0.521 & 0.860 & $\mathrm{C}$ & 3.616 & -7.283 & -10.241 & $\mathrm{H}$ & 0.325 & -6.219 & 4.676 \\
\hline $\mathrm{C}$ & 2.040 & 1.181 & 1.040 & $\mathrm{C}$ & -0.366 & -8.430 & -11.429 & C & -2.647 & -5.189 & 2.642 \\
\hline $\mathrm{H}$ & 2.245 & 2.185 & 1.429 & $\mathrm{H}$ & -0.206 & -8.832 & -12.443 & $\mathrm{H}$ & -3.529 & -4.886 & 2.068 \\
\hline $\mathrm{N}$ & 1.235 & 1.166 & -0.111 & $\mathrm{H}$ & -1.319 & -7.888 & -11.440 & $\mathrm{H}$ & -2.990 & -5.448 & 3.657 \\
\hline $\mathrm{C}$ & 1.104 & 2.384 & -0.930 & $\mathrm{C}$ & 2.923 & -9.654 & -10.667 & $\mathrm{~N}$ & -1.812 & -4.003 & 2.794 \\
\hline $\mathrm{H}$ & 0.045 & 2.520 & -1.172 & $\mathrm{H}$ & 3.862 & -9.934 & -10.175 & $\mathrm{C}$ & -0.564 & -4.119 & 3.520 \\
\hline $\mathrm{H}$ & 1.414 & 3.236 & -0.309 & $\mathrm{H}$ & 2.820 & -10.290 & -11.561 & $\mathrm{H}$ & -0.777 & -4.398 & 4.561 \\
\hline C & 4.386 & 1.028 & -0.289 & $\mathrm{~N}$ & 1.813 & -9.908 & -9.762 & $\mathrm{~N}$ & 0.489 & -4.998 & 2.971 \\
\hline $\mathrm{H}$ & 4.661 & 2.039 & 0.047 & $\mathrm{C}$ & 0.589 & -10.472 & -10.357 & $\mathrm{C}$ & 1.662 & -4.203 & 2.640 \\
\hline $\mathrm{H}$ & 5.269 & 0.384 & -0.224 & $\mathrm{H}$ & 0.832 & -10.965 & -11.308 & $\mathrm{~N}$ & 1.462 & -2.953 & 3.383 \\
\hline $\mathrm{N}$ & 3.807 & 1.010 & -1.564 & $\mathrm{~N}$ & -0.540 & -9.581 & -10.560 & $\mathrm{C}$ & 0.034 & -2.706 & 3.384 \\
\hline $\mathrm{C}$ & 4.473 & 0.294 & -2.672 & $\mathrm{C}$ & -1.147 & -9.393 & -9.244 & $\mathrm{H}$ & -0.222 & -2.047 & 4.225 \\
\hline $\mathrm{N}$ & 4.851 & 1.378 & -3.565 & $\mathrm{~N}$ & -0.990 & -10.692 & -8.597 & $\mathrm{~N}$ & -0.559 & -2.187 & 2.131 \\
\hline C & 3.714 & 2.285 & -3.576 & C & 0.072 & -11.450 & -9.280 & C & -1.511 & -3.189 & 1.622 \\
\hline $\mathrm{H}$ & 4.049 & 3.266 & -3.936 & $\mathrm{H}$ & -0.344 & -12.376 & -9.701 & C & 2.355 & -1.846 & 3.209 \\
\hline $\mathrm{N}$ & 2.497 & 1.872 & -4.290 & $\mathrm{~N}$ & 1.273 & -11.770 & -8.527 & $\mathrm{H}$ & 2.227 & -1.186 & 4.080 \\
\hline $\mathrm{C}$ & 1.399 & 1.719 & -3.348 & $\mathrm{C}$ & 2.047 & -10.532 & -8.463 & $\mathrm{H}$ & 3.382 & -2.231 & 3.229 \\
\hline $\mathrm{N}$ & 1.854 & 2.449 & -2.155 & $\mathrm{C}$ & 1.146 & -12.582 & -7.329 & $\mathrm{C}$ & -0.937 & -0.787 & 2.134 \\
\hline C & 3.280 & 2.305 & -2.095 & $\mathrm{H}$ & 2.153 & -12.694 & -6.909 & $\mathrm{H}$ & -1.090 & -0.432 & 3.166 \\
\hline $\mathrm{H}$ & 3.722 & 3.130 & -1.522 & $\mathrm{H}$ & 0.820 & -13.580 & -7.666 & $\mathrm{H}$ & -1.885 & -0.656 & 1.603 \\
\hline $\mathrm{C}$ & 2.257 & 2.506 & -5.596 & $\mathrm{C}$ & -2.160 & -11.446 & -8.168 & $\mathrm{H}$ & 1.205 & 0.654 & -3.121 \\
\hline $\mathrm{H}$ & 1.178 & 2.657 & -5.715 & $\mathrm{H}$ & -3.060 & -10.846 & -8.345 & $\mathrm{H}$ & 0.470 & 2.160 & -3.730 \\
\hline $\mathrm{H}$ & 2.732 & 3.500 & -5.599 & $\mathrm{H}$ & -2.250 & -12.359 & -8.778 & $\mathrm{H}$ & 1.833 & -0.109 & -6.525 \\
\hline C & 5.506 & 1.061 & -4.835 & $\mathrm{~N}$ & -2.204 & -11.880 & -6.781 & $\mathrm{H}$ & 1.014 & 0.982 & -7.677 \\
\hline $\mathrm{H}$ & 6.320 & 0.364 & -4.606 & $\mathrm{C}$ & -1.110 & -12.686 & -6.270 & $\mathrm{H}$ & 1.640 & -2.513 & -9.105 \\
\hline $\mathrm{H}$ & 5.968 & 2.003 & -5.170 & $\mathrm{H}$ & -1.106 & -13.654 & -6.792 & $\mathrm{H}$ & 0.586 & -2.029 & -10.463 \\
\hline $\mathrm{N}$ & 2.731 & 1.815 & -6.768 & $\mathrm{~N}$ & 0.245 & -12.106 & -6.287 & $\mathrm{H}$ & 0.688 & -5.726 & -9.931 \\
\hline C & 4.132 & 1.472 & -6.866 & $\mathrm{C}$ & 0.721 & -11.958 & -4.915 & $\mathrm{H}$ & -0.638 & -5.854 & -11.119 \\
\hline $\mathrm{H}$ & 4.737 & 2.389 & -6.855 & $\mathrm{~N}$ & -0.128 & -12.871 & -4.149 & $\mathrm{H}$ & -2.207 & -9.121 & -9.346 \\
\hline $\mathrm{N}$ & 4.669 & 0.504 & -5.878 & $\mathrm{C}$ & -1.440 & -12.807 & -4.768 & $\mathrm{H}$ & -0.642 & -8.596 & -8.667 \\
\hline C & 5.124 & -0.691 & -6.603 & $\mathrm{H}$ & -1.999 & -13.720 & -4.521 & $\mathrm{H}$ & -3.529 & -10.540 & -5.825 \\
\hline $\mathrm{N}$ & 5.300 & -0.219 & -7.972 & $\mathrm{~N}$ & -2.273 & -11.621 & -4.496 & $\mathrm{H}$ & -1.823 & -10.014 & -5.812 \\
\hline C & 4.212 & 0.711 & -8.202 & C & -2.492 & -10.892 & -5.742 & $\mathrm{H}$ & -4.083 & -9.516 & -1.989 \\
\hline $\mathrm{H}$ & 4.466 & 1.359 & -9.053 & C & -0.039 & -12.872 & -2.700 & $\mathrm{H}$ & -2.375 & -9.422 & -2.501 \\
\hline $\mathrm{N}$ & 2.850 & 0.166 & -8.372 & $\mathrm{H}$ & -0.497 & -13.818 & -2.365 & $\mathrm{H}$ & -3.679 & -6.520 & 0.668 \\
\hline $\mathrm{C}$ & 1.995 & 0.665 & -7.299 & $\mathrm{H}$ & 1.025 & -12.916 & -2.444 & $\mathrm{H}$ & -2.107 & -7.045 & 0.004 \\
\hline C & 2.335 & 0.120 & -9.744 & C & -3.367 & -11.797 & -3.552 & $\mathrm{H}$ & -2.422 & -2.716 & 1.235 \\
\hline $\mathrm{H}$ & 2.830 & 0.903 & -10.342 & $\mathrm{H}$ & -4.240 & -11.236 & -3.904 & $\mathrm{H}$ & -1.052 & -3.780 & 0.811 \\
\hline $\mathrm{H}$ & 1.264 & 0.353 & -9.725 & $\mathrm{H}$ & -3.654 & -12.860 & -3.513 & $\mathrm{H}$ & 0.304 & -0.734 & -0.405 \\
\hline $\mathrm{C}$ & 5.628 & -1.182 & -9.014 & $\mathrm{~N}$ & -3.130 & -11.392 & -2.175 & $\mathrm{H}$ & -0.807 & 0.659 & -0.350 \\
\hline $\mathrm{H}$ & 5.997 & -0.589 & -9.868 & $\mathrm{C}$ & -2.014 & -11.984 & -1.459 & $\mathrm{H}$ & 1.708 & -9.877 & -7.639 \\
\hline $\mathrm{H}$ & 6.471 & -1.778 & -8.645 & $\mathrm{H}$ & -2.195 & -13.061 & -1.341 & $\mathrm{H}$ & 3.112 & -10.751 & -8.310 \\
\hline $\mathrm{N}$ & 4.565 & -2.071 & -9.448 & $\mathrm{~N}$ & -0.655 & -11.759 & -1.984 & $\mathrm{H}$ & 3.051 & -7.249 & -9.291 \\
\hline $\mathrm{C}$ & 3.822 & -1.663 & -10.658 & $\mathrm{C}$ & 0.119 & -11.003 & -1.003 & $\mathrm{H}$ & 4.669 & -7.490 & -10.006 \\
\hline $\mathrm{H}$ & 4.427 & -0.962 & -11.249 & $\mathrm{~N}$ & -0.619 & -11.190 & 0.247 & $\mathrm{H}$ & 4.085 & -4.058 & -8.866 \\
\hline $\mathrm{N}$ & 2.492 & -1.115 & -10.479 & $\mathrm{C}$ & -2.021 & -11.217 & -0.122 & $\mathrm{H}$ & 5.820 & -3.766 & -9.171 \\
\hline C & 1.624 & -2.256 & -10.181 & $\mathrm{H}$ & -2.592 & -11.726 & 0.667 & $\mathrm{H}$ & 4.371 & -1.496 & -6.536 \\
\hline $\mathrm{N}$ & 2.175 & -3.338 & -10.990 & $\mathrm{~N}$ & -2.666 & -9.931 & -0.458 & $\mathrm{H}$ & 6.073 & -1.069 & -6.200 \\
\hline C & 3.553 & -2.994 & -11.388 & $\mathrm{C}$ & -3.090 & -9.966 & -1.858 & $\mathrm{H}$ & 3.774 & -0.420 & -3.136 \\
\hline $\mathrm{H}$ & 3.617 & -2.908 & -12.482 & $\mathrm{C}$ & -3.551 & -9.369 & 0.550 & $\mathrm{H}$ & 5.355 & -0.253 & -2.319 \\
\hline $\mathrm{N}$ & 4.635 & -3.842 & -10.918 & $\mathrm{H}$ & -3.932 & -10.171 & 1.204 & $\mathrm{H}$ & 4.049 & -1.536 & 1.160 \\
\hline $\mathrm{C}$ & 4.804 & -3.515 & -9.505 & $\mathrm{H}$ & -4.417 & -8.913 & 0.057 & $\mathrm{H}$ & 2.761 & -1.236 & -0.047 \\
\hline C & 4.644 & -5.241 & -11.316 & C & -0.221 & -10.457 & 1.431 & $\mathrm{H}$ & 2.590 & -4.694 & 2.964 \\
\hline $\mathrm{H}$ & 5.530 & -5.698 & -10.860 & $\mathrm{H}$ & 0.866 & -10.558 & 1.524 & $\mathrm{H}$ & 1.729 & -4.024 & 1.550 \\
\hline $\mathrm{H}$ & 4.797 & -5.247 & -12.407 & $\mathrm{H}$ & -0.674 & -10.984 & 2.287 & $\mathrm{H}$ & 1.430 & -8.538 & 2.021 \\
\hline C & 1.346 & -3.987 & -12.004 & $\mathrm{~N}$ & -0.569 & -9.037 & 1.500 & $\mathrm{H}$ & 0.589 & -7.320 & 1.022 \\
\hline $\mathrm{H}$ & 0.325 & -3.595 & -11.932 & C & -1.814 & -8.701 & 2.219 & $\mathrm{H}$ & 1.141 & -11.396 & -0.907 \\
\hline $\mathrm{H}$ & 1.728 & -3.726 & -13.005 & $\mathrm{H}$ & -2.071 & -9.507 & 2.920 & $\mathrm{H}$ & 0.185 & -9.936 & -1.285 \\
\hline $\mathrm{N}$ & 3.471 & -6.033 & -10.982 & $\mathrm{~N}$ & -2.987 & -8.362 & 1.436 & $\mathrm{H}$ & 1.777 & -12.248 & -4.822 \\
\hline C & 2.471 & -6.216 & -12.049 & $\mathrm{C}$ & -2.734 & -7.022 & 0.913 & $\mathrm{H}$ & 0.619 & -10.913 & -4.568 \\
\hline $\mathrm{H}$ & 2.939 & -6.055 & -13.030 & $\mathrm{~N}$ & -2.035 & -6.345 & 2.010 & $\mathrm{H}$ & 3.970 & 0.744 & 1.725 \\
\hline
\end{tabular}


Table A-1 Properties of the 0.001 electron/bohr ${ }^{3}$ isosurface $^{\mathrm{a}}$

\begin{tabular}{lccc}
\hline & Surface area & $\boldsymbol{v}$ & $\boldsymbol{\sigma}^{2}$ \\
\hline $\mathbf{1}$ & $\AA^{2}$ & & \\
$\mathbf{2}$ & 299.348108 & 0.074602 & 129.479052 \\
$\mathbf{3}$ & 399.190382 & 0.042670 & 223.556237 \\
$\mathbf{4}$ & 473.437435 & 0.050719 & 102.214768 \\
$\mathbf{1 3}$ & 263.248932 & 0.224873 & 139.149617 \\
$\mathbf{1 6}$ & 244.399860 & 0.123469 & 183.563748 \\
$\mathbf{1 7}$ & 246.589105 & 0.098217 & 199.930839 \\
$\mathbf{1 8}$ & 225.684331 & 0.184455 & 187.150236 \\
$\mathbf{1 9}$ & 241.435807 & 0.096536 & 199.243214 \\
$\mathbf{2 0}$ & 239.073950 & 0.089877 & 187.549339 \\
$\mathbf{2 1}$ & 316.929730 & 0.079351 & 155.784114 \\
$\mathbf{2 2}$ & 393.013874 & 0.039850 & 254.833461 \\
$\mathbf{2 3}$ & 393.588765 & 0.041232 & 299.588008 \\
$\mathbf{2 4}$ & 392.038469 & 0.049617 & 210.288572 \\
$\boldsymbol{\beta}-\mathbf{H M X}$ & 391.254792 & 0.042963 & 325.147974 \\
$\boldsymbol{\varepsilon - C L - 2 0}$ & 246.589894 & 0.145027 & 207.290893 \\
\hline
\end{tabular}

${ }^{\mathrm{a}}$ See Rice et al. (Rice BM, Pai SV, Hare J. Predicting heats of formation of energetic materials using quantum mechanical calculations. Combustion and Flame 1999;118,445-458) for the definition of $v$ and $\sigma^{2}$. 
INTENTIONALLY LEFT BLANK. 
Appendix B. Gas-Phase Enthalpies of Formation at $298 \mathrm{~K}\left[\Delta H_{f}(298)\right]$ and $\mathrm{N}-\mathrm{NO}_{2}$ Bond Dissociation Energies 
This appendix lists gas-phase enthalpies of formation at $298 \mathrm{~K}\left[\Delta H_{f}(298)\right]$ that were estimated by calculating heats of reaction for (hypothetical) isodesmic reactions. Reference-based $\Delta H_{f}{ }^{9}(298)$ values employed as bases for the calculations are provided in Table B-1. Table B-1 also lists $\Delta H_{f}$ (298) estimates for 1,3,5-trinitro-1,3,5-triazacyclohexane (RDX), 1,3,5,7-tetranitro-1,3,5,7tetraazacyclooctane (HMX), 4, 18, 22, 23, 24, and 25. Figure B-1 shows the structure notional conformers of HMX (HMX-1 and HMX-2). Figure B-2 plots recommended versus calculated $\Delta H_{f}$ (298) for molecules listed in Table B-1. The linear least squares fits to these plots were employed to correct $\Delta H_{f}{ }^{9}(298)$ estimates for 1, 2, 3, 20, 21, 26, 27, 28, 29, 30 and $\varepsilon$-CL-20 that were obtained via B3LYP/6-31+G(d,p)-, MPWB95/6-31+G(d,p)- and BHandHLYP/3-21G(d)based calculations. Those estimates are listed in Table B-2. $\mathrm{N}-\mathrm{NO}_{2}$ bond dissociation energies (BDEs) $\mathrm{N}-\mathrm{NO}_{2}$ BDEs for polycyclic nitramines (PCNAs) are summarized in Table B-3. 
Table B-1 Gas-phase $\Delta_{f} H_{g}$ (298) estimates (in kilocalories per mole) for relatively small PCNAs and molecules employed as bases for calculating gas-phase $\Delta_{f} H_{g}(298)$ estimates for larger PCNAs

\begin{tabular}{|c|c|c|c|c|c|c|c|c|}
\hline \multirow{2}{*}{ Isodesmic Reactions $^{\mathrm{a}}$} & \multicolumn{8}{|c|}{ Method } \\
\hline & $\mathrm{b}$ & c & $\mathrm{d}$ & e & $\mathrm{f}$ & g & $\mathrm{h}$ & $\mathrm{i}$ \\
\hline $\mathbf{C H}\left(\mathbf{N H}_{2}\right)_{3}+3 \mathrm{C}_{2} \mathrm{H}_{6}=3 \mathrm{CH}_{3} \mathrm{NH}_{2}+\left(\mathrm{CH}_{3}\right)_{3} \mathrm{CH}$ & -0.3 & 0.0 & -0.2 & -1.7 & 0.0 & -1.7 & -0.1 & -0.1 \\
\hline$\left(\mathbf{C H}_{3}\right)_{2} \mathbf{C H N H}{ }_{2}+\mathrm{C}_{2} \mathrm{H}_{6}=\left(\mathrm{CH}_{3}\right)_{3} \mathrm{CH}+\mathrm{CH}_{3} \mathrm{NH}_{2}$ & -20.3 & -20.2 & -20.2 & -20.8 & -20.3 & -20.6 & -20.3 & -20.3 \\
\hline $\mathbf{C H}{ }_{3} \mathbf{C H}\left(\mathbf{N H}_{2}\right)_{2}+2 \mathrm{C}_{2} \mathrm{H}_{6}=\left(\mathrm{CH}_{3}\right)_{3} \mathrm{CH}+2 \mathrm{CH}_{3} \mathrm{NH}_{2}$ & -11.2 & -11.1 & -11.1 & -12.1 & -11.1 & -12.0 & -11.2 & -11.2 \\
\hline $\mathbf{C H}\left(\mathbf{N H}_{2}\right)_{2} \mathbf{C H}\left(\mathbf{N H}_{2}\right)_{2}+2 \mathrm{CH}_{3} \mathrm{CH}_{2} \mathrm{CH}_{3}=\left(\mathrm{CH}_{3}\right)_{2} \mathrm{CHCH}\left(\mathrm{CH}_{3}\right)_{2}+2 \mathrm{CH}_{2}\left(\mathrm{NH}_{2}\right)_{2}$ & -2.9 & -2.7 & -2.8 & -4.4 & -2.7 & -4.4 & -2.7 & -2.8 \\
\hline$\left(\mathbf{C H}_{3}\right)_{2} \mathbf{C H C H}\left(\mathbf{C H}_{3}\right)_{2}+2 \mathrm{C}_{2} \mathrm{H}_{6}=2\left(\mathrm{CH}_{3}\right)_{3} \mathrm{CH}$ & -42.2 & -42.3 & -42.3 & -40.9 & -42.3 & -41.6 & -42.4 & -42.3 \\
\hline cyclobutane $+2 \mathrm{C}_{2} \mathrm{H}_{6}=2 \mathrm{CH}_{3} \mathrm{CH}_{2} \mathrm{CH}_{2} \mathrm{CH}_{3}$ & 6.2 & 6.4 & 6.1 & 4.3 & 7.0 & 3.7 & 7.3 & 6.6 \\
\hline cyclooctane $+8 \mathrm{C}_{2} \mathrm{H}_{6}=8 \mathrm{CH}_{3} \mathrm{CH}_{2} \mathrm{CH}_{3}$ & -28.6 & -28.5 & -28.8 & -26.3 & -27.9 & -27.4 & -27.9 & -28.3 \\
\hline piperazine $+2 \mathrm{CH}_{3} \mathrm{CH}_{2} \mathrm{CH}_{3}=$ cyclohexane $+2\left(\mathrm{CH}_{3}\right)_{2} \mathrm{NH}$ & 5.2 & 5.4 & 5.4 & 5.5 & 5.3 & 5.1 & 5.4 & 5.4 \\
\hline imidazolidine $+2 \mathrm{CH}_{3} \mathrm{CH}_{2} \mathrm{CH}_{3}=$ cyclopentane $+2\left(\mathrm{CH}_{3}\right)_{2} \mathrm{NH}$ & 14.6 & 13.9 & 14.0 & 14.8 & 14.5 & 14.5 & 14.0 & 14.2 \\
\hline $\begin{array}{l}\text { trans-bicyclo[3.3.0] octane }+2 \mathrm{CH}_{3} \mathrm{CH}_{2} \mathrm{CH}_{2} \mathrm{CH}_{3}=2 \text { cyclopentane }+ \\
\quad\left(\mathrm{CH}_{3}\right)_{2} \mathrm{CHCH}\left(\mathrm{CH}_{3}\right)_{2}\end{array}$ & -14.9 & -15.9 & -16.1 & -16.0 & -14.7 & -15.8 & -15.6 & -15.4 \\
\hline $\begin{array}{l}\text { cis-bicyclo[3.3.0]octane }+2 \mathrm{CH}_{3} \mathrm{CH}_{2} \mathrm{CH}_{2} \mathrm{CH}_{3}=2 \text { cyclopentane }+ \\
\quad\left(\mathrm{CH}_{3}\right)_{2} \mathrm{CHCH}\left(\mathrm{CH}_{3}\right)_{2}\end{array}$ & -21.8 & -23.0 & -23.1 & -22.4 & -21.8 & -23.2 & -23.2 & -22.6 \\
\hline $\begin{array}{l}\text { trans-octahydroimidazo[4,5-d]imidazole }+4 \mathrm{CH}_{3} \mathrm{CH}_{2} \mathrm{CH}_{3}= \\
\text { trans-bicyclo[3.3.0]octane }+4\left(\mathrm{CH}_{3}\right)_{2} \mathrm{NH}\end{array}$ & 53.1 & 53.0 & 53.4 & 54.0 & 53.0 & 53.3 & 53.1 & 53.1 \\
\hline $\begin{array}{l}\text { cis-octahydroimidazo[4,5-d]imidazole }+4 \mathrm{CH}_{3} \mathrm{CH}_{2} \mathrm{CH}_{3}= \\
\text { cis-bicyclo[3.3.0]octane }+4\left(\mathrm{CH}_{3}\right)_{2} \mathrm{NH}\end{array}$ & 31.3 & 31.4 & 31.7 & 31.4 & 31.4 & 30.4 & 31.0 & 31.4 \\
\hline hexahydro-1H-1,3,5-triazepine $+3 \mathrm{CH}_{3} \mathrm{CH}_{2} \mathrm{CH}_{3}=$ cycloheptane $+3\left(\mathrm{CH}_{3}\right)_{2} \mathrm{NH}$ & 14.1 & 14.3 & 14.2 & 13.5 & 14.2 & 14.0 & 14.7 & 14.3 \\
\hline $\begin{array}{l}\text { hexahydro-1,3,5-trinitro-1H-1,3,5-triazepine }+3\left(\mathrm{CH}_{3}\right)_{2} \mathrm{NH}=\text { hexahydro- } 1 \mathrm{H} \text { - } \\
\text { 1,3,5-triazepine }+3\left(\mathrm{CH}_{3}\right)_{2} \mathrm{NNO}_{2}\end{array}$ & 32.7 & 32.3 & & 33.8 & 32.4 & 36.6 & 31.8 & 32.3 \\
\hline octahydro-1,3,5,7-tetrazocine $+4 \mathrm{CH}_{3} \mathrm{CH}_{2} \mathrm{CH}_{3}=$ cyclooctane $+4\left(\mathrm{CH}_{3}\right)_{2} \mathrm{NH}$ & 27.8 & 28.2 & 28.2 & 26.9 & 28.1 & 26.0 & 28.4 & 28.1 \\
\hline $\begin{array}{l}\text { trans-bicyclo[4.3.0]nonane }+2 \mathrm{CH}_{3} \mathrm{CH}_{2} \mathrm{CH}_{2} \mathrm{CH}_{3}=\text { cyclopentane }+ \text { cyclohexane }+ \\
\quad\left(\mathrm{CH}_{3}\right)_{2} \mathrm{CHCH}\left(\mathrm{CH}_{3}\right)_{2}\end{array}$ & -32.5 & -32.9 & & -33.4 & -32.3 & -32.7 & -32.7 & -32.6 \\
\hline $\begin{array}{l}\text { cis-bicyclo[4.3.0]nonane }+2 \mathrm{CH}_{3} \mathrm{CH}_{2} \mathrm{CH}_{2} \mathrm{CH}_{3}=\text { cyclopentane }+ \text { cyclohexane }+ \\
\quad\left(\mathrm{CH}_{3}\right)_{2} \mathrm{CHCH}\left(\mathrm{CH}_{3}\right)_{2}\end{array}$ & -26.0 & -26.6 & & -25.9 & -26.0 & -26.4 & -26.3 & -26.2 \\
\hline $\begin{array}{l}\text { trans-bicyclo[4.4.0]decane }+2 \mathrm{CH}_{3} \mathrm{CH}_{2} \mathrm{CH}_{2} \mathrm{CH}_{3}=2 \text { cyclohexane }+ \\
\quad\left(\mathrm{CH}_{3}\right)_{2} \mathrm{CHCH}\left(\mathrm{CH}_{3}\right)_{2}\end{array}$ & -39.1 & -39.0 & & -39.3 & -39.0 & -38.6 & -38.9 & -39.0 \\
\hline $\begin{array}{l}\text { cis-bicyclo[4.4.0]decane }+2 \mathrm{CH}_{3} \mathrm{CH}_{2} \mathrm{CH}_{2} \mathrm{CH}_{3}=2 \text { cyclohexane }+ \\
\quad\left(\mathrm{CH}_{3}\right)_{2} \mathrm{CHCH}\left(\mathrm{CH}_{3}\right)_{2}\end{array}$ & -28.1 & -28.1 & & -27.4 & -28.1 & -27.5 & -28.0 & -28.1 \\
\hline $\begin{array}{l}\text { trans-bicyclo[5.4.0]undecane }+2 \mathrm{CH}_{3} \mathrm{CH}_{2} \mathrm{CH}_{2} \mathrm{CH}_{3}=\text { cyclohexane }+ \text { cycloheptane }+ \\
\quad\left(\mathrm{CH}_{3}\right)_{2} \mathrm{CHCH}\left(\mathrm{CH}_{3}\right)_{2}\end{array}$ & -41.1 & -41.1 & & -41.2 & -41.1 & -37.0 & -37.8 & -40.3 \\
\hline
\end{tabular}


Table B-1 Gas-phase $\Delta_{f} H_{g}$ (298) estimates (in kilocalories per mole) for relatively small PCNAs and molecules employed as bases for calculating gas-phase $\Delta_{f} H_{g}(298)$ estimates for larger PCNAs (continued)

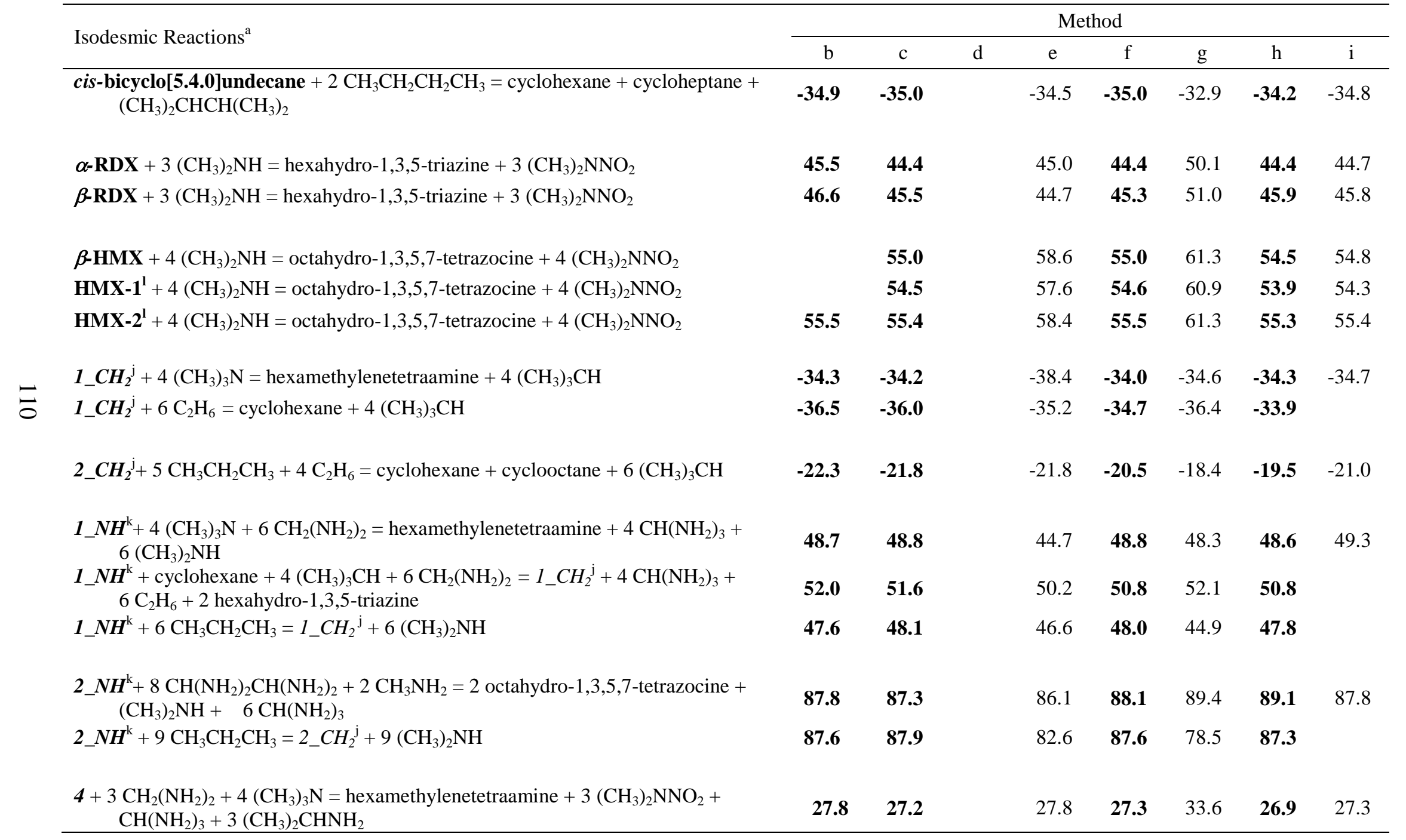


Table B-1 Gas-phase $\Delta_{f} H_{g}$ (298) estimates (in kilocalories per mole) for relatively small PCNAs and molecules employed as bases for calculating gas-phase $\Delta_{f} H_{g}$ (298) estimates for larger PCNAs (continued)

\begin{tabular}{|c|c|c|c|c|c|c|c|c|}
\hline \multirow{2}{*}{ 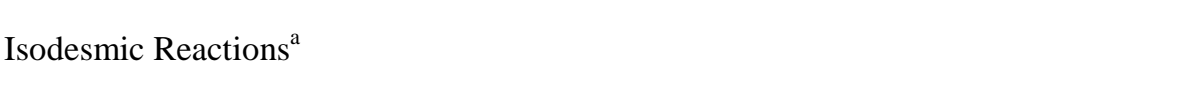 } & \multicolumn{8}{|c|}{ Method } \\
\hline & $\mathrm{b}$ & c & $\mathrm{d}$ & $\mathrm{e}$ & $\mathrm{f}$ & g & $\mathrm{h}$ & $\mathrm{i}$ \\
\hline $18+4\left(\mathrm{CH}_{3}\right)_{2} \mathrm{NH}=$ cis-octahydroimidazo $[4,5-d]$ imidazole $+4\left(\mathrm{CH}_{3}\right)_{2} \mathrm{NNO}_{2}$ & & 68.8 & & 70.9 & 68.9 & 77.1 & 68.7 & 68.8 \\
\hline $18+2 \mathrm{CH}_{3} \mathrm{CH}_{2} \mathrm{CH}_{3}=$ cis-bicyclo[3.3.0]octane $+2\left(\mathrm{CH}_{3}\right)_{2} \mathrm{NNO}_{2}$ & & 68.8 & & 70.2 & 68.9 & 76.3 & 68.9 & \\
\hline $22+4\left(\mathrm{CH}_{3}\right)_{2} \mathrm{NH}=$ trans-octahydroimidazo[4,5-d]imidazole $+4\left(\mathrm{CH}_{3}\right)_{2} \mathrm{NNO}_{2}$ & & 92.7 & & 96.5 & 92.6 & 104.8 & 92.8 & 92.7 \\
\hline $22+2 \mathrm{CH}_{3} \mathrm{CH}_{2} \mathrm{CH}_{3}=$ trans-bicyclo[3.3.0]octane $+2\left(\mathrm{CH}_{3}\right)_{2} \mathrm{NNO}_{2}$ & & 92.7 & & 97.4 & 92.5 & 105.0 & 92.7 & \\
\hline $\begin{aligned} 23+ & 2\left(\mathrm{CH}_{3}\right)_{3} \mathrm{~N}+3 \mathrm{CH}_{3} \mathrm{CH}_{2} \mathrm{NH}_{2}=\text { diazabicyclooctane }(\mathrm{DABCO})+3\left(\mathrm{CH}_{3}\right)_{2} \mathrm{NNO}_{2} \\
& +\mathrm{CH}\left(\mathrm{NH}_{2}\right)_{3}+\left(\mathrm{CH}_{3}\right)_{3} \mathrm{CH}\end{aligned}$ & 37.9 & 37.1 & & 40.1 & 37.1 & 42.4 & 36.8 & 37.2 \\
\hline 24_CH ${ }^{j}{ }^{\mathrm{j}}+12 \mathrm{C}_{2} \mathrm{H}_{6}=8\left(\mathrm{CH}_{3}\right)_{3} \mathrm{CH}$ & 51.1 & 52.1 & 52.1 & 50.7 & 53.9 & 46.4 & 55.5 & 53.1 \\
\hline 24_CH ${ }_{2}{ }^{\mathrm{j}}+4 \mathrm{CH}_{3} \mathrm{CH}_{2} \mathrm{CH}_{3}+2 \mathrm{C}_{2} \mathrm{H}_{6}=4\left(\mathrm{CH}_{3}\right)_{3} \mathrm{CH}+2$ cyclobutane & 52.3 & 52.8 & 53.6 & 55.1 & 53.4 & 51.8 & 54.3 & \\
\hline $24 \_N H^{\mathrm{k}}+2 \mathrm{C}_{2} \mathrm{H}_{6}+8 \mathrm{CH}_{3} \mathrm{NH}_{2}=4\left(\mathrm{CH}_{3}\right)_{2} \mathrm{NH}+4 \mathrm{CH}_{3} \mathrm{CH}\left(\mathrm{NH}_{2}\right)_{2}$ & 107.1 & 107.6 & 108.1 & 108.6 & 109.5 & 104.5 & 111.4 & 108.8 \\
\hline $24 \_N H^{\mathrm{k}}+4 \mathrm{CH}_{3} \mathrm{CH}_{2} \mathrm{CH}_{3}=24 \_\mathrm{CH}_{2}{ }^{\mathrm{j}}+4\left(\mathrm{CH}_{3}\right)_{2} \mathrm{NH}$ & 108.8 & 108.8 & 109.3 & 107.2 & 108.8 & 108.0 & 108.9 & \\
\hline $24+4\left(\mathrm{CH}_{3}\right)_{2} \mathrm{NH}=24-N H^{\mathrm{k}}+4\left(\mathrm{CH}_{3}\right)_{2} \mathrm{NNO}_{2}$ & & 147.0 & & 157.0 & 146.8 & 162.9 & 147.0 & 146.9 \\
\hline $24+4 \mathrm{CH}_{3} \mathrm{CH}_{2} \mathrm{CH}_{3}=24 \_\mathrm{CH}_{2}^{\mathrm{j}}+4\left(\mathrm{CH}_{3}\right)_{2} \mathrm{NNO}_{2}$ & & 147.0 & & 155.3 & 146.8 & 162.0 & 147.1 & \\
\hline $\begin{array}{l}24+4 \mathrm{CH}_{3} \mathrm{CH}_{2} \mathrm{CH}_{2} \mathrm{CH}_{3}+8 \mathrm{CH}_{3} \mathrm{NH}_{2}=4 \mathrm{CH}_{3} \mathrm{CH}\left(\mathrm{NH}_{2}\right)_{2}+2 \text { cyclobutane }+ \\
\quad 4\left(\mathrm{CH}_{3}\right)_{2} \mathrm{NNO}_{2}+2 \mathrm{C}_{2} \mathrm{H}_{6}\end{array}$ & & 146.2 & & 161.2 & 146.7 & 164.3 & 148.1 & \\
\hline 25_CH ${ }_{2}{ }^{\mathrm{j}}+2 \mathrm{CH}_{3} \mathrm{CH}_{2} \mathrm{CH}_{3}=$ trans-bicyclo[3.3.0]octane $+\left(\mathrm{CH}_{3}\right)_{2} \mathrm{CHCH}\left(\mathrm{CH}_{3}\right)_{2}$ & 15.0 & 15.3 & 16.1 & 15.5 & 16.0 & 11.9 & 16.6 & 15.8 \\
\hline $25 \_\boldsymbol{C H}_{2}{ }^{\mathrm{j}}+8 \mathrm{C}_{2} \mathrm{H}_{6}=2\left(\mathrm{CH}_{3}\right)_{2} \mathrm{CHCH}\left(\mathrm{CH}_{3}\right)_{2}+4 \mathrm{CH}_{3} \mathrm{CH}_{2} \mathrm{CH}_{3}$ & 13.8 & 14.8 & 15.3 & 12.6 & 16.7 & 9.2 & 18.2 & \\
\hline $\begin{array}{l}25 \_N H^{\mathrm{k}}+8 \mathrm{CH}_{3} \mathrm{NH}_{2}+\mathrm{C}_{2} \mathrm{H}_{6}=\left(\mathrm{CH}_{3}\right)_{2} \mathrm{CHCH}\left(\mathrm{CH}_{3}\right)_{2}+4\left(\mathrm{CH}_{3}\right)_{2} \mathrm{NH}+ \\
\quad 2 \mathrm{CH}_{3} \mathrm{CH}\left(\mathrm{NH}_{2}\right)_{2}\end{array}$ & 64.9 & 65.6 & 66.4 & 68.4 & 67.5 & 64.1 & 69.0 & 66.9 \\
\hline $\begin{array}{l}\text { 25_NH } N^{\mathrm{k}}+4 \mathrm{CH}_{3} \mathrm{CH}_{2} \mathrm{NH}_{2}+2 \mathrm{CH}_{2}\left(\mathrm{NH}_{2}\right)_{2}=2 \text { imidazolidine }+\left(\mathrm{CH}_{3}\right)_{2} \mathrm{CHCH}\left(\mathrm{CH}_{3}\right)_{2}+ \\
\quad 2 \mathrm{CH}_{3} \mathrm{CH}\left(\mathrm{NH}_{2}\right)_{2}+\mathrm{C}_{2} \mathrm{H}_{6}\end{array}$ & 66.1 & 66.4 & 67.3 & 68.1 & 67.0 & 64.3 & 67.9 & \\
\hline $\begin{array}{l}25 \_\mathrm{NH}^{\mathrm{k}}+2 \mathrm{CH}_{2}\left(\mathrm{NH}_{2}\right)_{2}=\text { trans-octahydroimidazo[4,5-d]imidazole + } \\
\left(\mathrm{CH}_{3}\right)_{2} \mathrm{CHCH}\left(\mathrm{CH}_{3}\right)_{2}\end{array}$ & 65.9 & 66.4 & 67.2 & 65.7 & 67.0 & 63.4 & 67.7 & \\
\hline $25 \_N H^{\mathrm{k}}+4 \mathrm{CH}_{3} \mathrm{CH}_{2} \mathrm{CH}_{3}=25 C_{C} \mathrm{CH}_{2}^{\mathrm{j}}+4\left(\mathrm{CH}_{3}\right)_{2} \mathrm{NH}$ & 66.6 & 66.9 & 67.6 & 67.1 & 67.0 & 67.2 & 66.8 & \\
\hline
\end{tabular}


Table B-1 Gas-phase $\Delta_{f} H_{g}$ (298) estimates (in kilocalories per mole) for relatively small PCNAs and molecules employed as bases for calculating gas-phase $\Delta_{f} H_{g}$ (298) estimates for larger PCNAs (continued)

\begin{tabular}{|c|c|c|c|c|c|c|c|c|}
\hline \multirow{2}{*}{ Isodesmic Reactions $^{\mathrm{a}}$} & \multicolumn{8}{|c|}{ Method } \\
\hline & $\mathrm{b}$ & C & $\mathrm{d}$ & e & $\mathrm{f}$ & g & $\mathrm{h}$ & i \\
\hline $25+4\left(\mathrm{CH}_{3}\right)_{2} \mathrm{NH}=25 \_\mathrm{NH}+4\left(\mathrm{CH}_{3}\right)_{2} \mathrm{NNO}_{2}$ & 110.6 & 108.9 & & 118.1 & 108.8 & 124.0 & 108.6 & 109.2 \\
\hline $25+4 \mathrm{CH}_{3} \mathrm{CH}_{2} \mathrm{CH}_{3}=25 \mathrm{CH}_{2}^{\mathrm{j}}+4\left(\mathrm{CH}_{3}\right)_{2} \mathrm{NNO}_{2}$ & 110.2 & 108.8 & & 116.5 & 108.7 & 122.9 & 108.6 & \\
\hline 26_C $\boldsymbol{C H}_{2}^{\mathrm{j}}+12 \mathrm{C}_{2} \mathrm{H}_{6}=3\left(\mathrm{CH}_{3}\right)_{2} \mathrm{CHCH}\left(\mathrm{CH}_{3}\right)_{2}+6 \mathrm{CH}_{3} \mathrm{CH}_{2} \mathrm{CH}_{3}$ & -27.0 & -25.7 & & -27.2 & -23.1 & -29.2 & -22.0 & -24.5 \\
\hline 26_C $\boldsymbol{C H}_{2}{ }^{\mathrm{j}}+6 \mathrm{C}_{2} \mathrm{H}_{6}=3\left(\mathrm{CH}_{3}\right)_{2} \mathrm{CHCH}\left(\mathrm{CH}_{3}\right)_{2}+$ cyclohexane & -26.6 & -25.6 & & -27.5 & -23.6 & -29.0 & -22.6 & \\
\hline 26_NH $\boldsymbol{N H}^{\mathrm{k}}+12 \mathrm{CH}_{3} \mathrm{NH}_{2}=3 \mathrm{CH}\left(\mathrm{NH}_{2}\right)_{2} \mathrm{CH}\left(\mathrm{NH}_{2}\right)_{2}+6\left(\mathrm{CH}_{3}\right)_{2} \mathrm{NH}$ & 53.8 & 54.8 & & 60.1 & 57.4 & 55.9 & 58.8 & 56.4 \\
\hline 26_NH $\mathbf{N H}^{\mathrm{k}}+6 \mathrm{CH}_{3} \mathrm{CH}_{2} \mathrm{CH}_{3}=26 \_\mathrm{CH}_{2}^{\mathrm{j}}+6\left(\mathrm{CH}_{3}\right)_{2} \mathrm{NH}$ & 55.8 & 56.6 & & 53.4 & 56.6 & 52.6 & 56.9 & \\
\hline 27_CH ${ }^{\mathrm{j}}+16 \mathrm{C}_{2} \mathrm{H}_{6}=4\left(\mathrm{CH}_{3}\right)_{2} \mathrm{CHCH}\left(\mathrm{CH}_{3}\right)_{2}+8 \mathrm{CH}_{3} \mathrm{CH}_{2} \mathrm{CH}_{3}$ & -14.7 & -13.4 & & -17.7 & -10.2 & -13.1 & -7.8 & -12.2 \\
\hline 27_C $\boldsymbol{C H}_{2}{ }^{\mathrm{j}}+8 \mathrm{C}_{2} \mathrm{H}_{6}=4\left(\mathrm{CH}_{3}\right)_{2} \mathrm{CHCH}\left(\mathrm{CH}_{3}\right)_{2}+$ cyclooctane & -14.5 & -13.2 & & -19.7 & -10.6 & -14.0 & -8.2 & \\
\hline 27_CH ${ }_{2}{ }^{\mathrm{j}}+2 \mathrm{C}_{2} \mathrm{H}_{6}+4 \mathrm{CH}_{3} \mathrm{CH}_{2} \mathrm{CH}_{2} \mathrm{CH}_{3}=2$ cis-bicyclo[4.4.0]decane $+4\left(\mathrm{CH}_{3}\right)_{3} \mathrm{CH}$ & -13.8 & -13.3 & & -17.6 & -12.6 & -11.3 & -11.2 & \\
\hline 27_NH ${ }^{\mathrm{k}}+8 \mathrm{CH}_{3} \mathrm{CH}_{2} \mathrm{CH}_{3}=27 C_{C}{ }_{2}^{\mathrm{j}}+8\left(\mathrm{CH}_{3}\right)_{2} \mathrm{NH}$ & & 82.4 & & 78.3 & 82.1 & 74.7 & 81.3 & 82.0 \\
\hline 27_NH $H^{\mathrm{k}}+8 \mathrm{CH}_{3} \mathrm{NH}_{2}=4 \mathrm{CH}\left(\mathrm{NH}_{2}\right)_{2} \mathrm{CH}\left(\mathrm{NH}_{2}\right)_{2}+$ cyclooctane & & 81.4 & & 64.4 & 83.4 & 79.0 & 85.2 & \\
\hline 28_CH ${ }^{j}{ }^{\mathrm{j}}+12 \mathrm{C}_{2} \mathrm{H}_{6}=4\left(\mathrm{CH}_{3}\right)_{2} \mathrm{CHCH}\left(\mathrm{CH}_{3}\right)_{2}+4 \mathrm{CH}_{3} \mathrm{CH}_{2} \mathrm{CH}_{2} \mathrm{CH}_{3}$ & -6.3 & -5.0 & & -9.4 & -1.8 & -6.3 & 0.1 & -3.7 \\
\hline $\begin{array}{l}\text { 28_CH } \text { CH }_{2}{ }^{j}+5 \mathrm{C}_{2} \mathrm{H}_{6}+3 \mathrm{CH}_{3} \mathrm{CH}_{2} \mathrm{CH}_{3}=4\left(\mathrm{CH}_{3}\right)_{2} \mathrm{CHCH}\left(\mathrm{CH}_{3}\right)_{2}+\text { cyclopentane }+ \\
\text { cyclohexane }\end{array}$ & -5.3 & -5.0 & & -8.5 & -2.5 & -4.6 & -1.6 & \\
\hline $\begin{array}{l}\text { 28_CH }{ }_{2}{ }^{\mathrm{j}}+3 \mathrm{CH}_{3} \mathrm{CH}_{2} \mathrm{CH}_{2} \mathrm{CH}_{3}+\mathrm{C}_{2} \mathrm{H}_{6}=2\left(\mathrm{CH}_{3}\right)_{2} \mathrm{CHCH}\left(\mathrm{CH}_{3}\right)_{2}+ \\
2 \text { trans-bicyclo[4.3.0]nonane }\end{array}$ & -4.7 & -4.7 & & -6.1 & -4.1 & -2.5 & -3.2 & \\
\hline 28_NH $\mathbf{N H}^{\mathrm{k}}+8 \mathrm{CH}_{3} \mathrm{CH}_{2} \mathrm{CH}_{3}=28 \_\mathrm{CH}_{2}^{\mathrm{j}}+8\left(\mathrm{CH}_{3}\right)_{2} \mathrm{NH}$ & & 84.2 & & 77.3 & 84.1 & 75.3 & 83.8 & 84.0 \\
\hline $\begin{array}{l}\text { 28_NH }{ }^{\mathrm{k}}+3 \mathrm{CH}_{3} \mathrm{CH}_{2} \mathrm{CH}_{2} \mathrm{CH}_{3}+\mathrm{C}_{2} \mathrm{H}_{6}=2 \mathrm{CH}\left(\mathrm{NH}_{2}\right)_{2} \mathrm{CH}\left(\mathrm{NH}_{2}\right)_{2}+ \\
\quad 2 \text { trans-bicyclo[4.3.0]nonane }\end{array}$ & & 83.6 & & 62.3 & 83.8 & 77.3 & 84.7 & \\
\hline $\begin{array}{l}\text { 29_CH } \text { CH }_{2}{ }^{\mathrm{j}}+5 \mathrm{CH}_{3} \mathrm{CH}_{2} \mathrm{CH}_{3}+3 \mathrm{C}_{2} \mathrm{H}_{6}=\text { cyclohexane }+ \text { cycloheptane }+ \\
\quad 4\left(\mathrm{CH}_{3}\right)_{2} \mathrm{CHCH}\left(\mathrm{CH}_{3}\right)_{2}\end{array}$ & -14.2 & -13.4 & & -17.0 & -11.5 & -11.8 & -9.4 & -14.0 \\
\hline $\begin{array}{l}\text { 29_C } \mathrm{CH}_{2}^{\mathrm{j}}+5 \mathrm{CH}_{3} \mathrm{CH}_{2} \mathrm{CH}_{3}=2\left(\mathrm{CH}_{3}\right)_{2} \mathrm{CHCH}\left(\mathrm{CH}_{3}\right)_{2}+2 \text { trans-bicyclo[5.4.0]undecane } \\
+\mathrm{C}_{2} \mathrm{H}_{6}\end{array}$ & -15.6 & -15.1 & & -19.8 & -14.4 & -20.1 & -18.4 & \\
\hline
\end{tabular}


Table B-1 Gas-phase $\Delta_{f} H_{g}$ (298) estimates (in kilocalories per mole) for relatively small PCNAs and molecules employed as bases for calculating gas-phase $\Delta_{f} H_{g}(298)$ estimates for larger PCNAs (continued)

\begin{tabular}{|c|c|c|c|c|c|c|c|c|}
\hline \multirow{2}{*}{ Isodesmic Reactions $^{\mathrm{a}}$} & \multicolumn{8}{|c|}{ Method } \\
\hline & $\mathrm{b}$ & c & d & $\mathrm{e}$ & $\mathrm{f}$ & g & $\mathrm{h}$ & $\mathrm{i}$ \\
\hline 29_NH $\mathrm{NH}^{\mathrm{k}}+8 \mathrm{CH}_{3} \mathrm{CH}_{2} \mathrm{CH}_{3}=29 \_\mathrm{CH}_{2}{ }^{\mathrm{j}}+8\left(\mathrm{CH}_{3}\right)_{2} \mathrm{NH}$ & & 87.9 & & 82.0 & 87.7 & 80.0 & 87.5 & 87.7 \\
\hline $\begin{array}{l}\text { 29_NH } \mathrm{NH}^{\mathrm{k}}+4 \mathrm{CH}_{2}\left(\mathrm{NH}_{2}\right)_{2}+8 \mathrm{CH}_{3} \mathrm{CH}_{2} \mathrm{NH}_{2}=2 \text { hexahydro- } 1 \mathrm{H}-1,3,5 \text {-triazepine }+ \\
\text { piperazine }+8 \mathrm{CH}_{3} \mathrm{CH}\left(\mathrm{NH}_{2}\right)_{2}\end{array}$ & & 85.8 & & 86.1 & 87.1 & 86.7 & 88.5 & \\
\hline 30_CH ${ }^{\mathrm{j}}+4 \mathrm{CH}_{3} \mathrm{CH}_{2} \mathrm{CH}_{3}=2\left(\mathrm{CH}_{3}\right)_{2} \mathrm{CHCH}\left(\mathrm{CH}_{3}\right)_{2}+2$ trans-bicyclo[3.3.0]octane & -3.3 & -2.9 & & -4.1 & -2.3 & 1.1 & -0.5 & -2.3 \\
\hline 30_NH $\boldsymbol{H H}^{\mathrm{k}}+8 \mathrm{CH}_{3} \mathrm{CH}_{2} \mathrm{CH}_{3}=30 \_\mathrm{CH}_{2}^{\mathrm{j}}+8\left(\mathrm{CH}_{3}\right)_{2} \mathrm{NH}$ & 78.0 & 79.2 & & 71.9 & 79.3 & 69.3 & 78.5 & 78.8 \\
\hline $\begin{array}{l}\text { 30_NH } \boldsymbol{H}^{\mathrm{k}}+4 \mathrm{CH}_{2}\left(\mathrm{NH}_{2}\right)_{2}+8 \mathrm{CH}_{3} \mathrm{CH}_{2} \mathrm{NH}_{2}=4 \text { imidazolidine }+ \\
\quad 2 \mathrm{CH}\left(\mathrm{NH}_{2}\right)_{2} \mathrm{CH}\left(\mathrm{NH}_{2}\right)_{2}+4 \mathrm{CH}_{3} \mathrm{CH}\left(\mathrm{NH}_{2}\right)_{2}+2 \mathrm{C}_{2} \mathrm{H}_{6}\end{array}$ & 75.2 & 79.8 & & 59.0 & 80.2 & 73.1 & 80.6 & \\
\hline $\begin{array}{l}\boldsymbol{\varepsilon} \text {-CL-20_CH }{ }_{2}{ }^{\mathrm{j}}+\text { cyclohexane }+2 \mathrm{CH}_{3} \mathrm{CH}_{2} \mathrm{CH}_{3}=2 \text { trans-bicyclo[4.3.0]nonane }+ \\
\quad\left(\mathrm{CH}_{3}\right)_{2} \mathrm{CHCH}\left(\mathrm{CH}_{3}\right)_{2}\end{array}$ & -19.6 & -19.6 & & -18.9 & -18.9 & -19.9 & -17.9 & -19.0 \\
\hline $\begin{array}{c}\boldsymbol{\varepsilon} \text {-CL-20_NH } \boldsymbol{N H}^{\mathrm{k}}+3\left(\mathrm{CH}_{3}\right)_{2} \mathrm{CHCH}\left(\mathrm{CH}_{3}\right)_{2}+2 \text { cyclopentane }+ \text { cyclohexane }+ \\
2 \mathrm{CH}_{2}\left(\mathrm{NH}_{2}\right)_{2}+8 \mathrm{CH}_{3} \mathrm{CH}_{2} \mathrm{NH}_{2}=2 \text { piperazine }+ \text { imidazolidine }+ \\
3 \mathrm{CH}\left(\mathrm{NH}_{2}\right)_{2} \mathrm{CH}\left(\mathrm{NH}_{2}\right)_{2}+\varepsilon-\mathrm{CL}-20 \_\mathrm{CH}_{2}{ }^{\mathrm{j}}\end{array}$ & 57.8 & 58.7 & & 61.6 & 57.4 & 60.0 & 57.8 & 58.0 \\
\hline
\end{tabular}

${ }^{\mathrm{a}}$ Estimate is for molecule in bold type. ${ }^{\mathrm{b} C B S}-\mathrm{QB} 3 .{ }^{\mathrm{c}} \mathrm{G} 3 \mathrm{MP} 2 \mathrm{~B} 3 .{ }^{\mathrm{d}} \mathrm{G} 4 .{ }^{\mathrm{e}} \mathrm{B} 3 \mathrm{LYP} / 6-31+\mathrm{g}(\mathrm{d}, \mathrm{p}) .{ }^{\mathrm{f}} \mathrm{G} 3 \mathrm{MP} 2 / / \mathrm{B} 3 \mathrm{LYP} / 6-31+\mathrm{g}(\mathrm{d}, \mathrm{p}) .{ }^{\mathrm{g}} \mathrm{MPWB} 95 / 6-31+\mathrm{g}(\mathrm{d}, \mathrm{p})$.

${ }^{\mathrm{h}} \mathrm{G} 3 \mathrm{MP} 2 / / \mathrm{MPWB} 95 / 6-31+\mathrm{g}(\mathrm{d}, \mathrm{p})$. ${ }^{i}$ Recommended value, which is the average of results obtained with the the CBS-QB3, G3MP2B3, G4, G3MP2//B3LYP/6-31+g(d,p), and G3MP2//MPWB95/6-31+g(d,p) models. Values employed to compute the average are bold. ${ }^{j} \mathbf{X} \mathbf{C H}_{2}$ : A molecule in which the - $\mathrm{NNO}_{2}$ groups of the target molecule $(\mathbf{X})$ have been replaced by $-\mathrm{CH}_{2}$ groups. ${ }^{\mathrm{k}} \mathbf{X} \_\mathbf{N H}$ : A molecule in which the $-\mathrm{NNO}_{2}$ groups of the target molecule $(\mathbf{X})$ have been replaced by $-\mathrm{NH}$ groups.

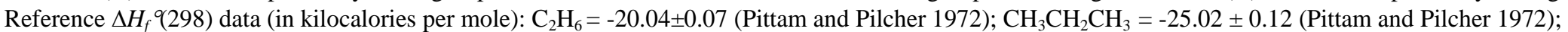
$\mathrm{CH}_{3} \mathrm{CH}_{2} \mathrm{CH}_{2} \mathrm{CH}_{3}=30.03 \pm 0.16$ (Pittam and Pilcher 1972); $\left(\mathrm{CH}_{3}\right)_{3} \mathrm{CH}=-32.07 \pm 0.15$ (Pittam and Pilcher 1972); cyclopentane = $-18.26 \pm 0.19$ (McCullough et al. 1959); cyclohexane $=-29.78$ (Spitzer and Huffman 1947); cycloheptane $=-28.23($ DeTar 1991) ; benzene $=19.8 \pm 0.2$ (Roux et al. 2008); 1,3,5-triazine $=53.98 \pm 0.21$ (Bystrom 1982); HMTA= 43.13 (McQuaid and Chen 2013); $\mathrm{DABCO}=20.68$ (McQuaid and Chen 2013); $\mathrm{CH}_{3} \mathrm{NH}_{2}=-5.26$ (derived from the average of $\Delta H_{r}(298)$ estimates for $\mathrm{CH}_{3} \mathrm{NH}_{2}+\mathrm{CH}_{4}=\mathrm{C}_{2} \mathrm{H}_{6}+\mathrm{NH}_{3}$ produced by results from CBS-APNO, G4, CBSQB3, and G3MP2 models); $\mathrm{CH}_{3} \mathrm{CH}_{2} \mathrm{NH}_{2}=-12.11$ (derived from the average of $\Delta H_{r}(298)$ estimates produced for $\mathrm{CH}_{3} \mathrm{CH}_{2} \mathrm{NH}_{2}+\mathrm{C}_{2} \mathrm{H}_{6}=\mathrm{CH}_{3} \mathrm{CH}_{2} \mathrm{CH}_{3}+\mathrm{CH}_{3} \mathrm{NH}_{2}$ produced by CBS-APNO, G4, CBSQB3, and G3MP2 models); $\left(\mathrm{CH}_{3}\right)_{2} \mathrm{NH}^{2}=$ -4.24 (derived from the average of $\Delta H_{r}(298)$ estimates produced for $\left(\mathrm{CH}_{3}\right)_{2} \mathrm{NH}_{2}+\mathrm{NH}_{3}=2 \mathrm{CH}_{3} \mathrm{NH}_{2}$ by the results from CBS-APNO, G4, CBSQB3, and G3MP2 models); $\left(\mathrm{CH}_{3}\right)_{3} \mathrm{~N}=-6.54$ (derived from the average of $\Delta H_{r}(298)$ estimates for $\left(\mathrm{CH}_{3}\right)_{3} \mathrm{~N}+2 \mathrm{NH}_{3}=3 \mathrm{CH}_{3} \mathrm{NH}_{2}$ by CBS-APNO, G4, CBSQB3, and G3MP2 models); hexahydro-1,3,5-triazine $=18.26$ (derived from the average of $\Delta H_{r}(298)$ estimates for hexahydro-1,3,5-triazine + benzene $=1,3,5$-triazine + cyclohexane produced by CBS-APNO, G4, CBSQB3, and G3MP2 results); $\mathrm{CH}_{2}\left(\mathrm{NH}_{2}\right)_{2}=-2.38$ (derived from the average of $\Delta H_{r}(298)$ estimates produced for $\mathrm{CH}_{2}\left(\mathrm{NH}_{2}\right)_{2}+\mathrm{C}_{2} \mathrm{H}_{6}=$ $\mathrm{CH}_{3} \mathrm{CH}_{2} \mathrm{NH}_{2}+\mathrm{CH}_{3} \mathrm{NH}_{2}$ by CBS-APNO, G4, CBS-QB3, and G3MP2 results). 
Table B-2 Gas-phase $\Delta_{f} H_{g}(298)$ estimates (in kilocalories per mole) for 1, 2, 3, 20, 21, 26, 27, 28, 29, 30, and $\boldsymbol{\varepsilon}$-CL-20

\begin{tabular}{|c|c|c|c|c|c|c|c|}
\hline \multirow{2}{*}{ Isodesmic Reactions $^{\mathrm{a}}$} & \multicolumn{7}{|c|}{ Method } \\
\hline & $\mathrm{b}$ & C & d & $\mathrm{e}$ & $\mathrm{f}$ & g & $\mathrm{h}$ \\
\hline $\mathbf{1}+6\left(\mathrm{CH}_{3}\right)_{2} \mathrm{NH}=1 \_N H^{\mathrm{i}}+6\left(\mathrm{CH}_{3}\right)_{2} \mathrm{NNO}_{2}$ & 128.1 & 125.9 & 141.2 & 135.1 & & & 128.3 \\
\hline $1+6 \mathrm{CH}_{2}\left(\mathrm{NH}_{2}\right)_{2}=2 \beta-\mathrm{RDX}+4 \mathrm{CH}\left(\mathrm{NH}_{2}\right)_{3}$ & 130.7 & 128.5 & 131.9 & 126.2 & & & \\
\hline $1+6 \mathrm{CH}_{3} \mathrm{CH}_{2} \mathrm{CH}_{3}=1 \_\mathrm{CH}_{2}+6\left(\mathrm{CH}_{3}\right)_{2} \mathrm{NNO}_{2}$ & 125.4 & 123.3 & 136.9 & 130.9 & & & \\
\hline $2+9\left(\mathrm{CH}_{3}\right)_{2} \mathrm{NH}=2 \_N H^{\mathrm{i}}+9\left(\mathrm{CH}_{3}\right)_{2} \mathrm{NNO}_{2}$ & & & 219.1 & 209.6 & & & 202.4 \\
\hline $2+9 \mathrm{CH}_{3} \mathrm{CH}_{2} \mathrm{CH}_{3}=2 \_\mathrm{CH}_{2}+9\left(\mathrm{CH}_{3}\right)_{2} \mathrm{NNO}_{2}$ & & & 209.8 & 200.7 & & & \\
\hline $2+\left(\mathrm{CH}_{3}\right)_{2} \mathrm{NNO}_{2}+10 \mathrm{CH}_{2}\left(\mathrm{NH}_{2}\right)_{2}=\mathrm{HMX}-1^{1}+2 \beta-\mathrm{RDX}+6 \mathrm{CH}\left(\mathrm{NH}_{2}\right)_{3}+2 \mathrm{CH}_{3} \mathrm{NH}_{2}$ & & & 205.8 & 196.8 & & & \\
\hline $3+12 \mathrm{CH}_{2}\left(\mathrm{NH}_{2}\right)_{2}=3 \mathrm{HMX}-1^{1}+8 \mathrm{CH}\left(\mathrm{NH}_{2}\right)_{3}$ & & & & & 322.4 & 272.6 & 272.6 \\
\hline $20+10 \mathrm{CH}_{2}\left(\mathrm{NH}_{2}\right)_{2}=5 \mathrm{HMX}-1^{1}+5 \mathrm{CH}\left(\mathrm{NH}_{2}\right)_{2} \mathrm{CH}\left(\mathrm{NH}_{2}\right)_{2}$ & & & & & 555.3 & 470.8 & 470.8 \\
\hline $21+12 \mathrm{CH}_{2}\left(\mathrm{NH}_{2}\right)_{2}=6 \mathrm{HMX}-1^{1}+6 \mathrm{CH}\left(\mathrm{NH}_{2}\right)_{2} \mathrm{CH}\left(\mathrm{NH}_{2}\right)_{2}$ & & & & & 605.1 & 513.2 & 513.2 \\
\hline $27+8\left(\mathrm{CH}_{3}\right)_{2} \mathrm{NH}=27 \_N H^{\mathrm{i}}+8\left(\mathrm{CH}_{3}\right)_{2} \mathrm{NNO}_{2}$ & 167.1 & 164.0 & 177.2 & 169.5 & & & 164.1 \\
\hline $27+8 \mathrm{CH}_{3} \mathrm{CH}_{2} \mathrm{CH}_{3}=27-\mathrm{CH}_{2}+8\left(\mathrm{CH}_{3}\right)_{2} \mathrm{NNO}_{2}$ & 163.5 & 160.4 & 169.9 & 162.5 & & & \\
\hline $28+8\left(\mathrm{CH}_{3}\right)_{2} \mathrm{NH}=28 \_N H^{\mathrm{i}}+8\left(\mathrm{CH}_{3}\right)_{2} \mathrm{NNO}_{2}$ & 168.8 & 165.6 & 179.3 & 171.6 & & & 164.9 \\
\hline $28+8 \mathrm{CH}_{3} \mathrm{CH}_{2} \mathrm{CH}_{3}=28-\mathrm{CH}_{2}+8\left(\mathrm{CH}_{3}\right)_{2} \mathrm{NNO}_{2}$ & 162.0 & 159.1 & 170.7 & 163.2 & & & \\
\hline
\end{tabular}


Table B-2 Gas-phase $\Delta_{f} H_{g}(298)$ estimates (in kilocalories per mole) for 1, 2, 3, 20, 21, 26, 27, 28, 29, 30, and $\boldsymbol{\varepsilon}$-CL-20 (continued)

\begin{tabular}{|c|c|c|c|c|c|c|c|}
\hline \multirow{2}{*}{ Isodesmic Reactions $^{\mathrm{a}}$} & \multicolumn{7}{|c|}{ Method } \\
\hline & $\mathrm{b}$ & C & $\mathrm{d}$ & e & $\mathrm{f}$ & g & h \\
\hline $29+8\left(\mathrm{CH}_{3}\right)_{2} \mathrm{NH}=29 \_N H^{\mathrm{i}}+8\left(\mathrm{CH}_{3}\right)_{2} \mathrm{NNO}_{2}$ & & & 190.0 & 181.8 & & & 178.1 \\
\hline $29+8 \mathrm{CH}_{3} \mathrm{CH}_{2} \mathrm{CH}_{3}=29 \_\mathrm{CH}_{2}+8\left(\mathrm{CH}_{3}\right)_{2} \mathrm{NNO}_{2}$ & & & 182.3 & 174.4 & & & \\
\hline $30+8\left(\mathrm{CH}_{3}\right)_{2} \mathrm{NH}=30 \_N H^{\mathrm{i}}+8\left(\mathrm{CH}_{3}\right)_{2} \mathrm{NNO}_{2}$ & 161.7 & 158.7 & 171.8 & 164.3 & & & 157.5 \\
\hline $30+8 \mathrm{CH}_{3} \mathrm{CH}_{2} \mathrm{CH}_{3}=30 \_\mathrm{CH}_{2}+8\left(\mathrm{CH}_{3}\right)_{2} \mathrm{NNO}_{2}$ & 154.8 & 152.0 & 162.2 & 155.2 & & & \\
\hline$\varepsilon$-CL-20 $+6\left(\mathrm{CH}_{3}\right)_{2} \mathrm{NH}=\varepsilon-\mathrm{CL}-20 \_N H^{\mathrm{i}}+6\left(\mathrm{CH}_{3}\right)_{2} \mathrm{NNO}_{2}$ & 124.0 & 121.9 & 131.9 & 126.1 & & & 123.4 \\
\hline$\varepsilon$-CL-20 $+6 \mathrm{CH}_{3} \mathrm{CH}_{2} \mathrm{CH}_{3}=\varepsilon-\mathrm{CL}-20 \_\mathrm{CH}_{2}+6\left(\mathrm{CH}_{3}\right)_{2} \mathrm{NNO}_{2}$ & 121.1 & 119.1 & 127.8 & 122.3 & & & \\
\hline $\boldsymbol{\varepsilon}$-CL-20 $+12 \mathrm{CH}_{3} \mathrm{NH}_{2}=3 \mathrm{CH}\left(\mathrm{NH}_{2}\right)_{2} \mathrm{CH}\left(\mathrm{NH}_{2}\right)_{2}+12\left(\mathrm{CH}_{3}\right)_{2} \mathrm{NNO}_{2}$ & 127.0 & 124.8 & 132.0 & 126.3 & & & \\
\hline
\end{tabular}

${ }^{\mathrm{a}}$ Estimate is for the molecule in bold type. ${ }^{\mathrm{b}} \mathrm{B} 3 \mathrm{LYP} / 6-31+\mathrm{g}(\mathrm{d}, \mathrm{p}) .{ }^{\mathrm{c}} \mathrm{B} 3 \mathrm{LYP} / 6-31+\mathrm{g}(\mathrm{d}, \mathrm{p})$ value corrected based on the linear regression presented in Fig. B-2(a).

${ }^{\mathrm{e}}$ MPWB95/6-31+g(d,p). ${ }^{\mathrm{e}}$ MPWB95/6-31+g(d,p) value corrected based on linear regression presented in Fig. B-1(b). MPWB95/6-31+g(d,p) ${ }^{\mathrm{g}} \mathrm{BHandHLYP/3-21g(d)} \mathrm{value}$

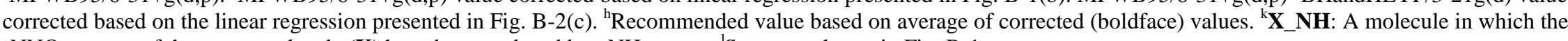

$-\mathrm{NNO}_{2}$ groups of the target molecule $(\mathbf{X})$ have been replaced by $-\mathrm{NH}$ groups. 'Structure shown in Fig. B-1. 

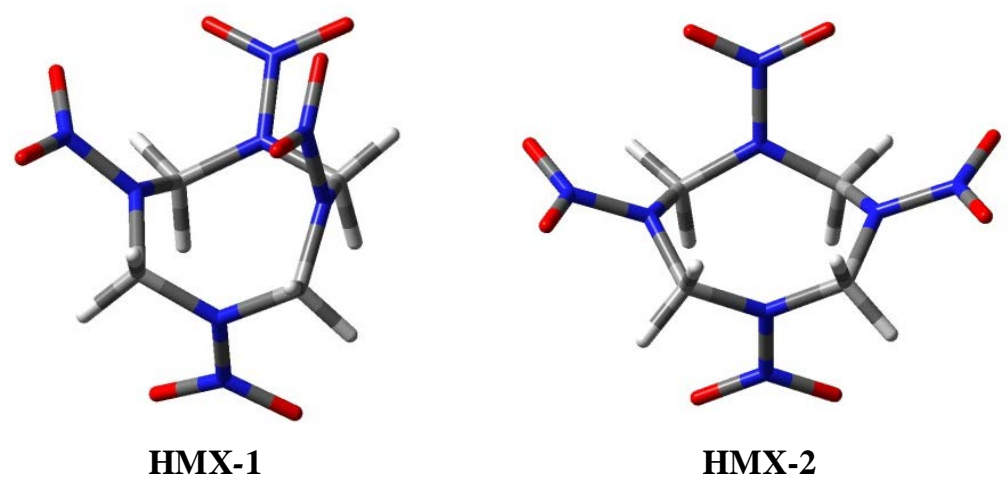

HMX-2

Fig. B-1 Notional conformers of HMX 


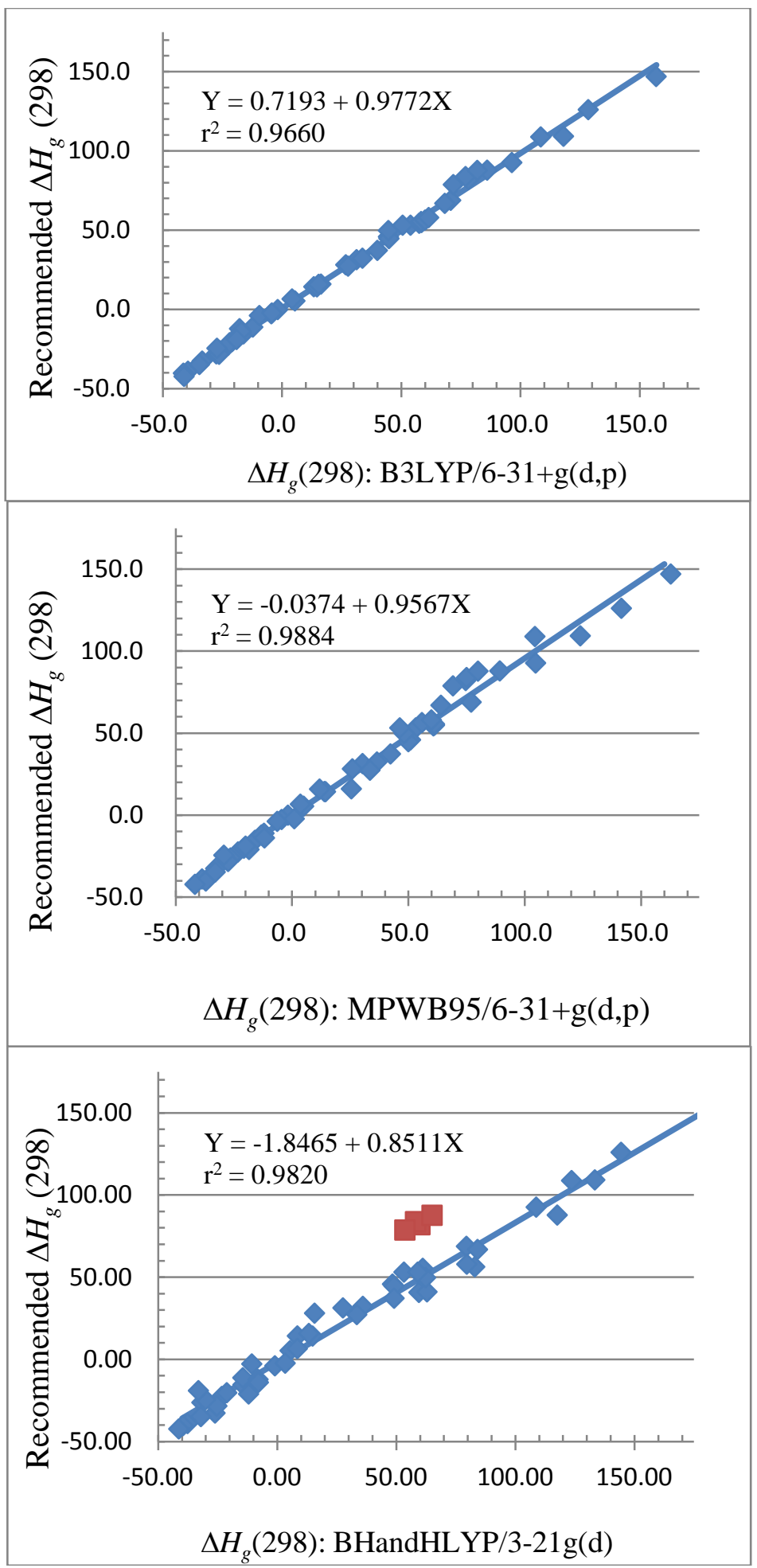

(a)

(b)

(c)

Fig. B-2 Recommended vs. estimated $\Delta_{f} H_{g}$ (298) values for molecules listed in Table B-1. (a) B3LYP/631+g(d,p); (b) MPWB95/6-31+g(d,p); and (c) BHandHLYP/3-21g(d). Note that the red data points were not included in the least-squares fit. 
Table B-3 Estimates for PCNA N-NO ${ }_{2}$ bond dissociation energies (in kilocalories per mole) ${ }^{\mathrm{a}}$

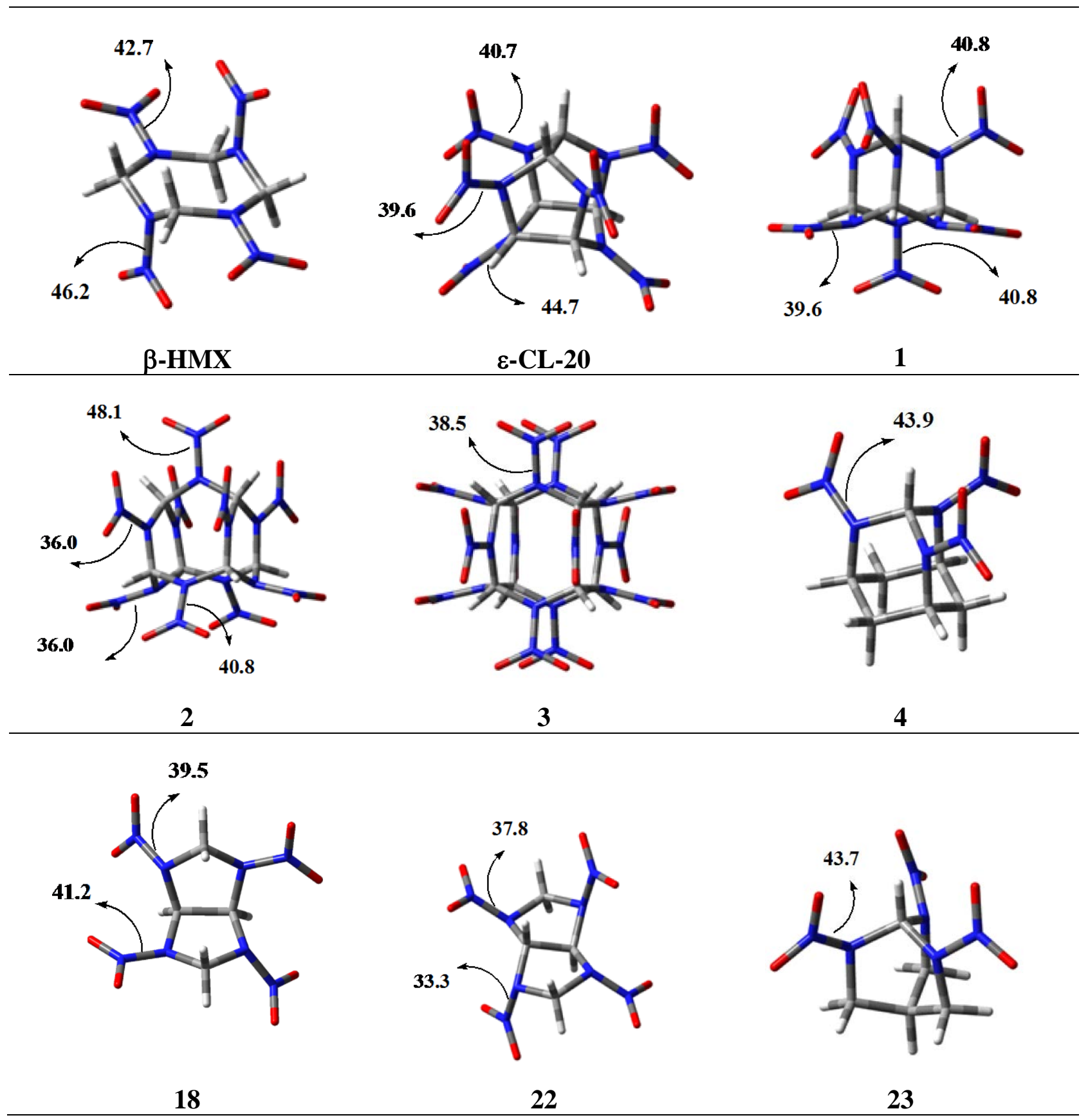


Table B-3 Estimates for PCNA N-NO 2 bond dissociation energies (in kilocalories per mole) (continued) ${ }^{\mathrm{a}}$

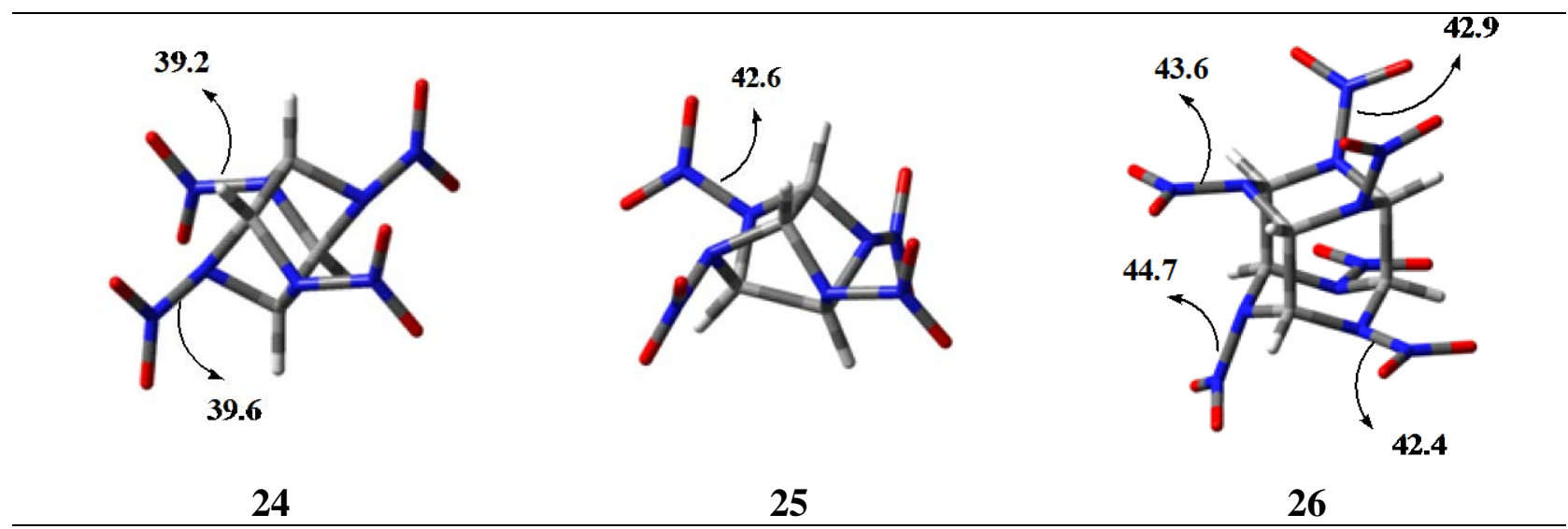

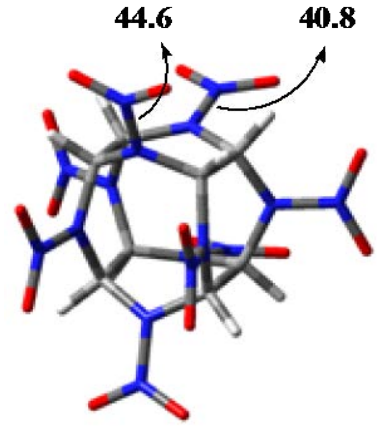

27

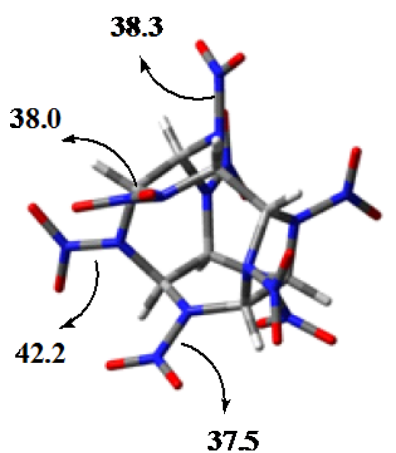

28

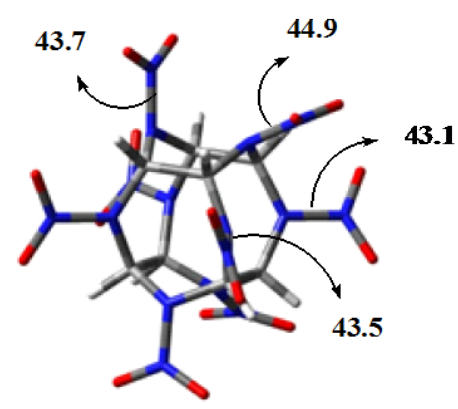

29

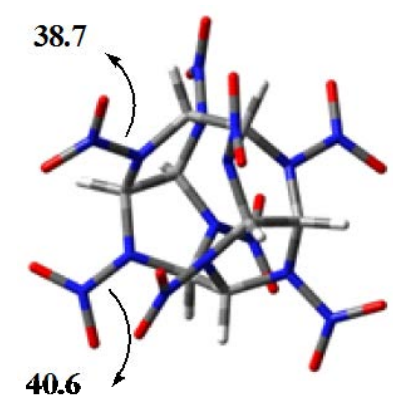

30

${ }^{\mathrm{a}}$ Bond dissociation energies (BDEs) were calculated from the BDE of $\left(\mathrm{CH}_{3}\right)_{2} \mathrm{~N}-\mathrm{NO}_{2}$ (46.4 kilocalories per mole) and enthalpies changes estimated for $\mathrm{XN} \cdot+\left(\mathrm{CH}_{3}\right)_{2} \mathrm{NNO}_{2} \leftrightarrow \mathrm{XNNO}_{2}+\left(\mathrm{CH}_{3}\right)_{2} \mathrm{~N} \cdot$ reactions. 


\section{References}

Bystrom K. The stabilization energy of 1,3,5-triazine derived from measurements of the enthalpies of combustion and sublimation. Journal of Chemical Thermodynamics. 1982;14:865-870.

DeTar DF. Experimental formal steric enthalpy. 1. Alkanes and cycloalkanes. Journal of Organic Chemistry. 1991;56(4):1463-1470.

McCullough JP, Pennington RE, Smith JC, Hossenlopp IA, Waddington G. Thermodynamics of cyclopentane, methylcyclopentane and 1,cis-3-dimethylcyclopentane: Verification of the concept of pseudorotation. Journal of the American Chemical Society. 1959;81:5880-5883.

McQuaid MJ, Chen C-C. $\mathrm{BH}_{3}$-amine and $\mathrm{B}\left(\mathrm{CH}_{3}\right)_{3}$-amine adducts as additives for liquid/gel hypergols and solid hybrid rocket motor fuels: property and performance predictions. Aberdeen Proving Ground (MD): Army Research Laboratory (US); 2014. Report No.: ARLTR-6749. Also available at http://www.arl.army.mil/www/default.cfm?technical_report=6979

Pittam DA, Pilcher G. Measurements of heats of combustion by flame calorimetry. Part 8.Methane, ethane, propane, n-butane and 2-methylpropane. Journal of the Chemical Society. Faraday Transactions 1. 1972;68:2224-2229.

Roux MV, Temprado M, Chickos JS, Nagano Y. Critically evaluated thermochemical properties of polycyclic aromatic hydrocarbons. Journal of Physical and Chemical Reference Data. 2008;37(4):1855-1996.

Spitzer R, Huffman HM. The heats of combustion of cyclopentane, cyclohexane, cycloheptane and cyclooctane. Journal of the American Chemical Society. 1947;69:211-213. 


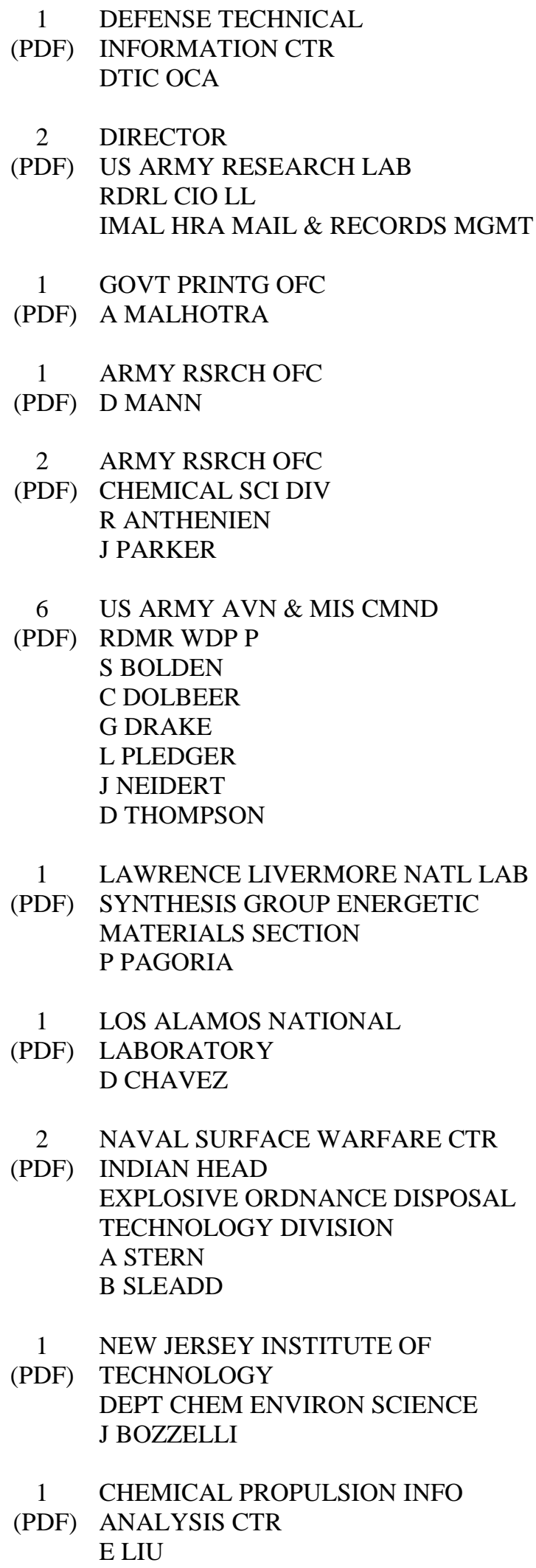

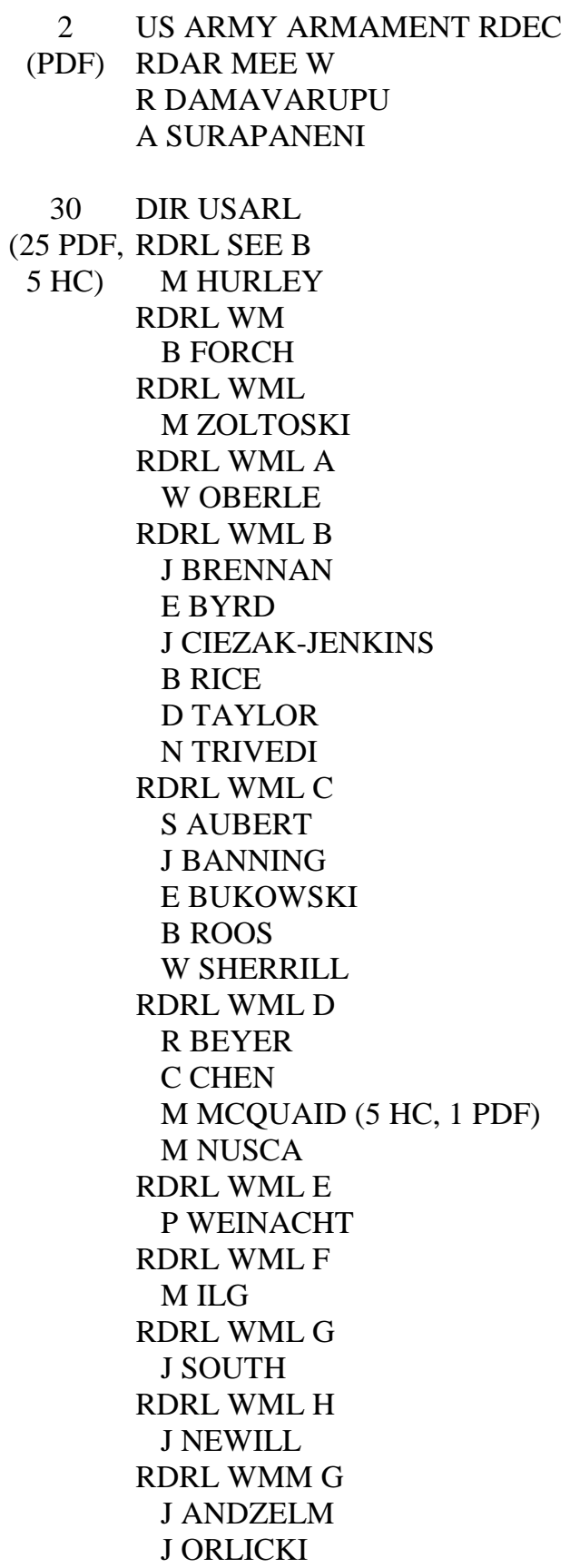


INTENTIONALLY LEFT BLANK. 